\title{
COMPARAÇÕES DE MARCADORES MOLECULARES E CRUZAMENTOS DIALÉLICOS NA ALOCAÇÃO DE LINHAGENS DE MILHO EM GRUPOS HETERÓTICOS
}

\author{
ROGÉRIO DE MELO COSTA PINTO
}

Engenheiro Agrônomo

Orientador: Prof. Dr. CLÁUDIO LOPES DE SOUZA JÚNIOR Co-orientadora: Prof. Dra. ANETE PEREIRA DE SOUZA

Tese apresentada à Escola Superior de Agricultura "Luiz de Queiroz", Universidade de São Paulo, para a obtenção do título de Doutor em Agronomia, Área de Concentração: Genética e Melhoramento de Plantas.

PIRACICABA

Estado de São Paulo - Brasil

Junho de 2000 


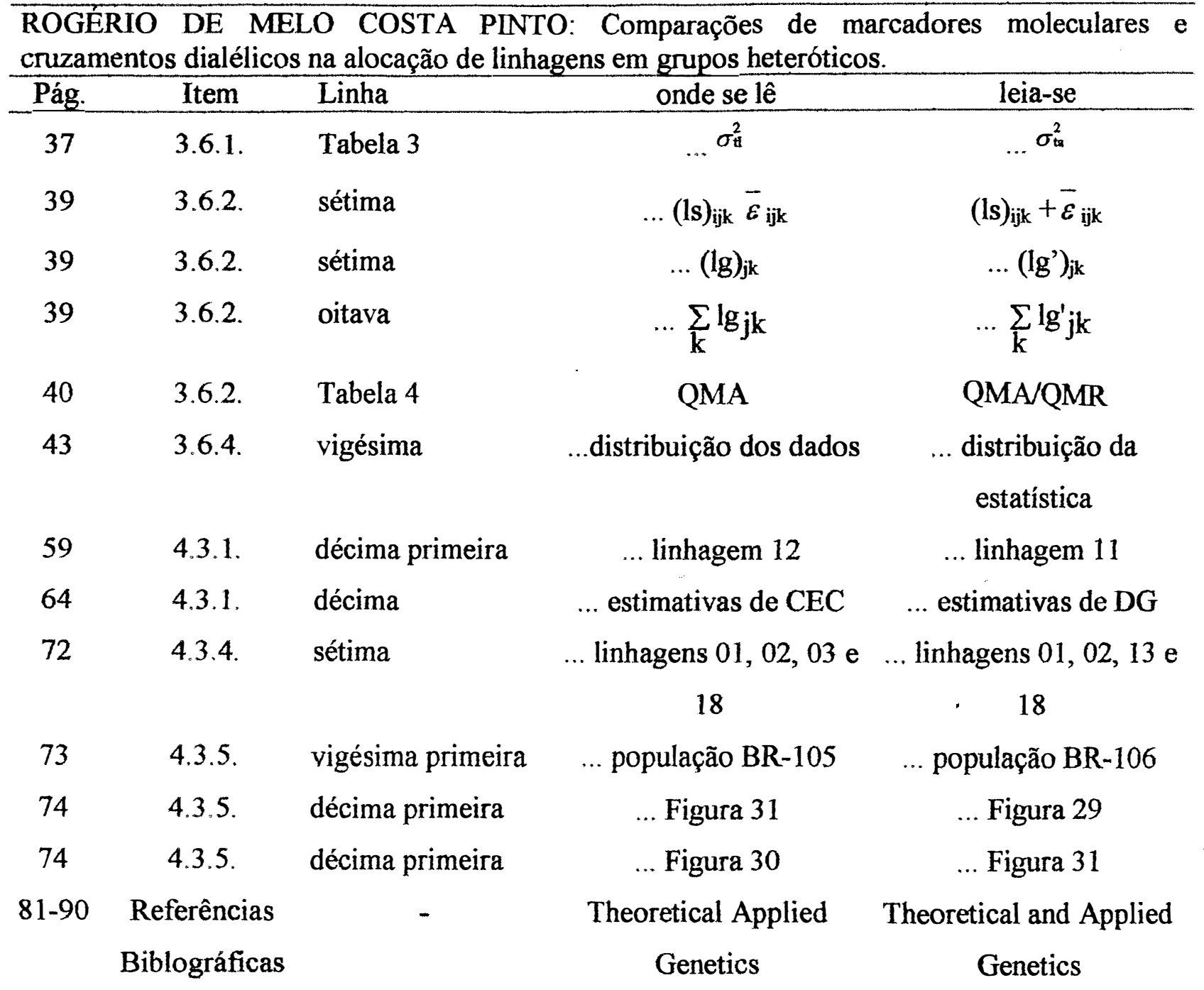




\section{Dados Internacionais de Catalogação na Publicação (CIP) DIVISÃO DE BIBLIOTECA E DOCUMENTAÇÃO - Campus "Luiz de Queiroz"/USP}

\section{Pinto, Rogério de Melo Costa}

Comparações de marcadores moleculares e cruzamentos dialélicos na alocação de linhagens de milho em grupos heteróticos / Rogério de Melo Costa Pinto. - - Piracicaba, 2000.

$147 \mathrm{p}$.

Tese (doutorado) - Escola Superior de Agricultura Luiz de Queiroz, 2000.

Bibliografia.

1. Cruzamento dialélico 2. Diversidade genética 3. Heterose 4. Linhagem vegetal 5. Marcador genético 6. Milho I. Título

CDD 633.15

"Permitida a cópla total ou parcial deste documento, descle que citada a fonte - $\mathrm{O}$ autor" 
Aos meus pais e

aos meus irmãos

OFEREÇO

À minha esposa Luciana e ao meu filho Pedro 


\section{AGRADECIMENTOS}

Ao Professor Dr. Cláudio Lopes de Souza Júnior, pela orientação, amizade, atenção e pela minha formação desde o mestrado até a elaboração do presente trabalho.

À Professora Anete Pereira de Souza do CEBMEG/UNICAMP pela coorientação, pela disponibilização dos dados de RFLP e pela atenção dispensada durante a realização desse trabalho.

Aos professores do Departamento de Genética da ESALQ/USP, pelo apoio e ensinamentos.

Aos amigos e colegas do curso de pós-graduação do Departamento de Genética da ESALQ/USP pelos momentos de amizade e companheirismo. Não citarei nomes, pois foram tantos que demandaria grande número de páginas.

Aos funcionários do Departamento de Genética da ESALQ/USP, em especial aqueles que contribuíram diretamente para a realização desse trabalho, Antônio Jocelino Desidério e Ariberto Soares de Oliveira.

Às bibliotecárias Silvana Oliveira, Silvana Gregório e Elisabeth pelo auxílio e amizade no decorrer do curso.

Ao Conselho Nacional Científico e Tecnológico (CNPq) pelo apoio financeiro.

À Universidade Estadual de Santa Cruz (UESC) pelas facilidades concedidas para a finalização da tese. 


\section{SUMÁRIO}

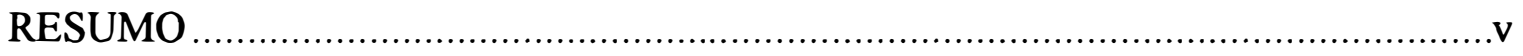

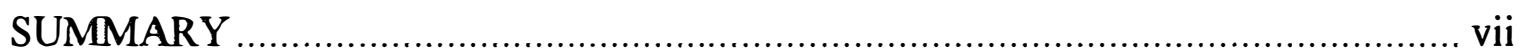

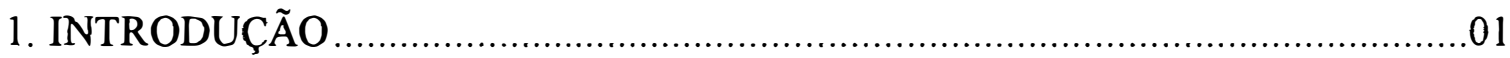

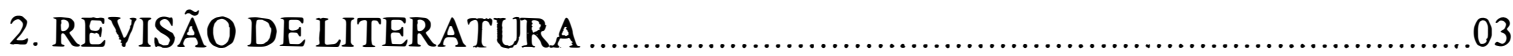

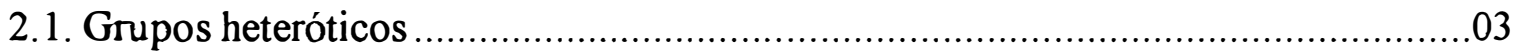

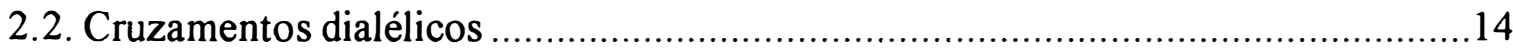

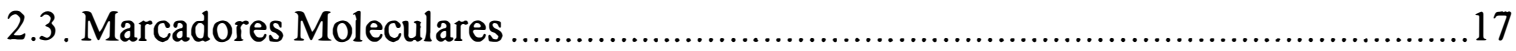

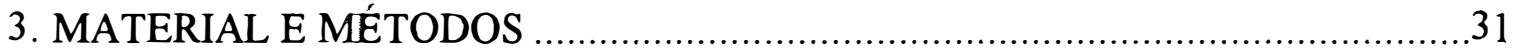

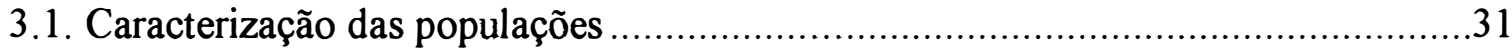

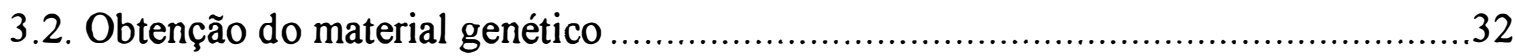

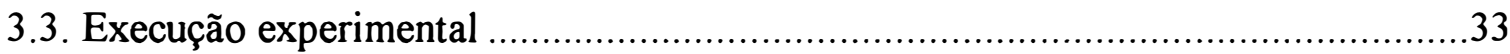

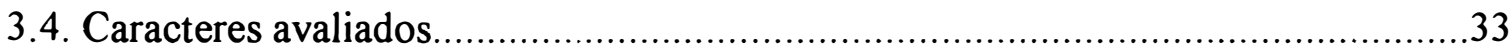

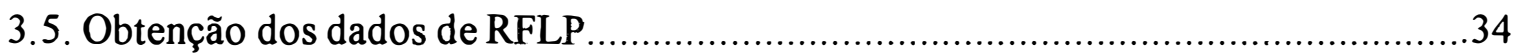

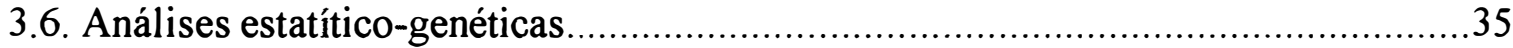

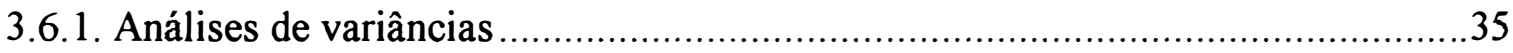

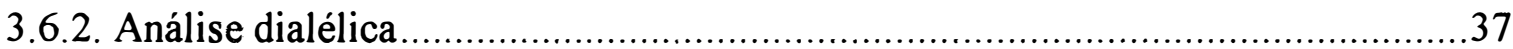

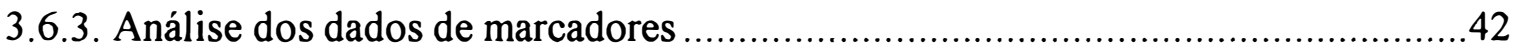

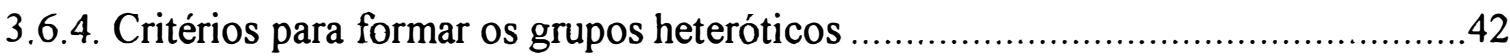

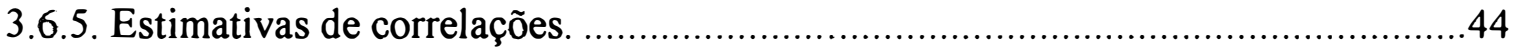

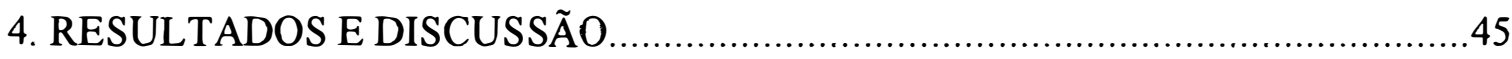

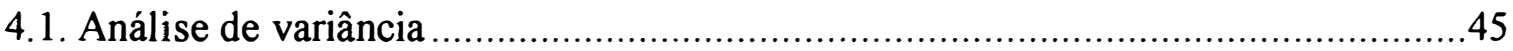

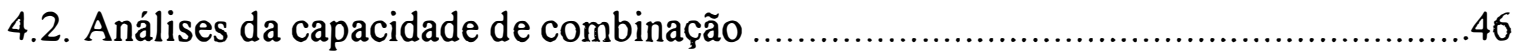

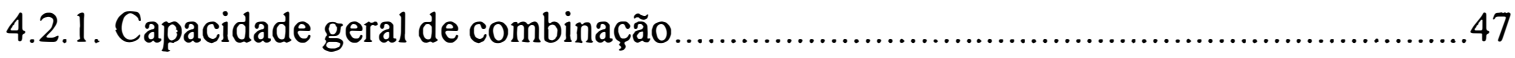

4.2.2. Capacidade específica de combinação ............................................................. 51 


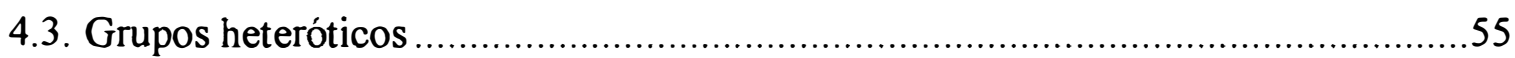

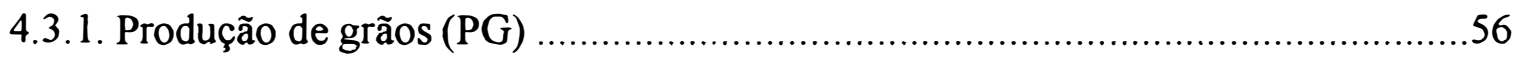

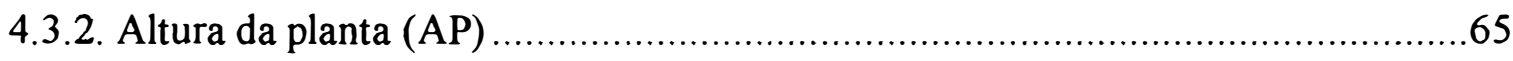

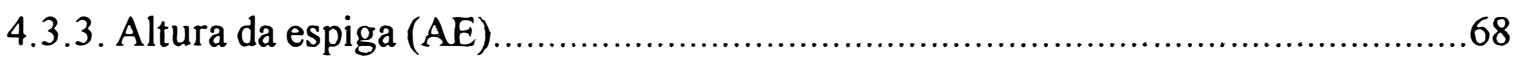

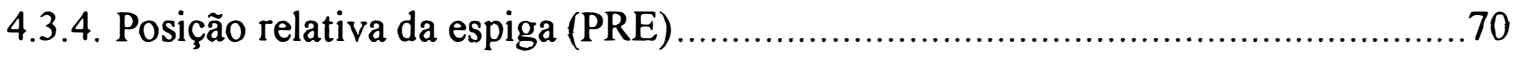

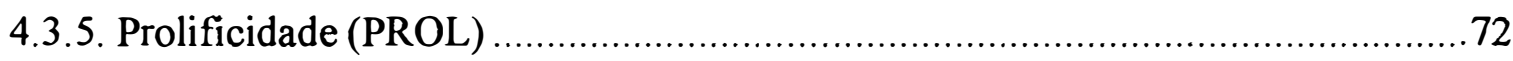

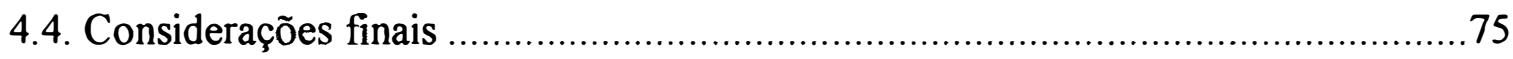

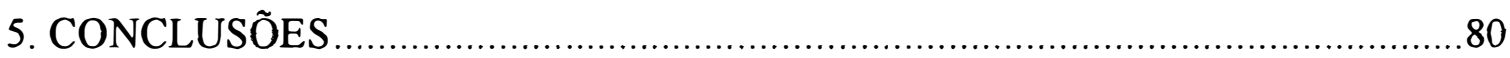

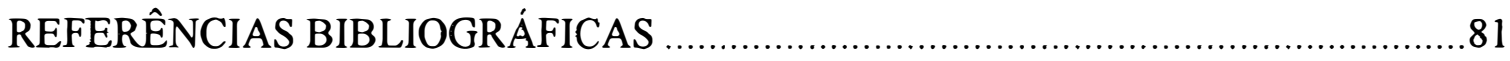

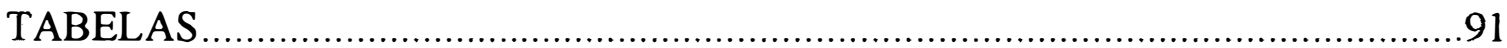

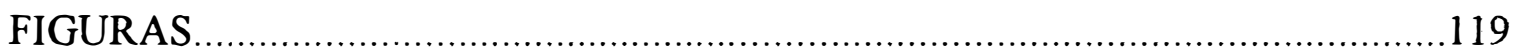




\title{
COMPARAÇÕES DE MARCADORES MOLECULARES E CRUZAMENTOS DIALÉLICOS NA ALOCAÇÃO DE LINHAGENS DE MILHO EM GRUPOS HETERÓTICOS
}

\author{
Autor: ROGÉRIO DE MELO COSTA PINTO \\ Orientador: Prof. Dr. CLÁUDIO LOPES DE SOUZA JÚNIOR \\ Co-orientadora: Prof. Dra. ANETE PEREIRA DE SOUZA
}

\section{RESUMO}

O objetivo deste trabalho foi comparar o uso de estimativas da capacidade específica de combinação (CEC) e marcadores moleculares RFLP para alocar linhagens de milho em grupos heteróticos. Oito linhagens $S_{3}$ derivadas da população BR-105 e 10 derivadas da população BR-106 foram cruzadas à nível intra e interpopulacional seguindo um sistema dialélico. Oitenta híbridos simples interpopulacionais e 28 e 45 híbridos simples intrapopulacionais foram obtidos e avaliados em látices em três ambientes. Foram avaliados os caracteres produção de grãos (PG), altura da planta (AP), altura da espiga (AE), posição relativa da espiga (PRE) e prolificidade (PROL).

As estimativas da capacidade geral de combinação (CGC) e capacidade específica de combinação (CEC) foram obtidas segundo o método 4, modelo I de Griffing (1956), para todas as características. As análises de marcadores moleculares RFLP foram feitas usando 88 sondas de DNA e 4 enzimas de restrição, no qual 1.429 bandas polimórficas foram identificadas. A partir destes dados foram computadas as distâncias genéticas (DG) entre pares de linhagens. A partir das estimativas de CEC e DG, as linhagens foram alocadas aos respectivos grupos heteróticos utilizando-se o método UPGMA para a construção do dendograma e a dispersão gráfica pelo método de ordenação de coordenadas principais. 
Para o caráter PG, as linhagens foram alocadas em quatro grupos heteróticos a partir das estimativas de CEC, no qual as linhagens de cada população foram subdivididas em dois grupos. A partir dos dados de RFLP, as linhagens também foram alocadas em quatro grupos heteróticos e, também, as linhagens de cada população foram subdivididas em dois grupos heteróticos. Os grupos heteróticos obtidos a partir das análises de CEC e de RFLP foram similares, indicando que o uso dos marcadores moleculares pode ser eficiente para alocar linhagens de milho em grupos heteróticos. Para as outras características, o uso das estimativas de CEC não foi eficiente para alocar as linhagens em grupos heteróticos.

Os resultados mostraram que os marcadores moleculares foram tão eficientes quanto as análises a partir das estimativas de CEC para o caráter PG na alocação das linhagens de milho em grupos heteróticos. Então, como a produção de grãos é a principal característica para o melhoramento de milho, os marcadores RFLP podem ser eficientemente usados para alocar as linhagens em grupos heteróticos, reduzindo a necessidade de se obter cruzamentos e suas avaliações em experimentos com repetições, bem como as análises estatísticas dos experimentos. Assim, o tempo usualmente necessário para alocar as linhagens de milho em grupos heteróticos corretos pode ser consideravelmente reduzido pela substituição das análises dialélicas pelo uso dos marcadores RFLP. 


\title{
COMPARISONS OF MOLECULAR MARKERS AND DIALLEL CROSSES TO ASSIGN MAIZE LINES TO HETEROTIC GROUPS
}

\author{
Author: ROGÉRIO DE MELO COSTA PINTO \\ Adviser: Prof. Dr. CLÁUDIO LOPES DE SOUZA JÚNIOR \\ Co-adviser: Prof. Dra. ANETE PEREIRA DE SOUZA
}

\section{SUMMARY}

The objective of this research was to compare the use of estimates of specific combining ability (SCA) and RFLP molecular markers to allocate maize lines to heterotic groups. Eight $S_{3}$ lines derived from population BR-105 and 10 derived from population BR-106 were crossed at intra- and interpopulation levels following a diallel system. Eighty interpopulation single-crosses, and 28 and 45 intrapopulation singlecrosses were obtained and evaluated in lattice designs across three environments. Data were recorded on grain yield $(\mathrm{GY})$, plant height $(\mathrm{PH})$, ear height $(\mathrm{EH})$, ear placement $(\mathrm{EP}=\mathrm{EH} / \mathrm{PH})$, and prolificacy $(\mathrm{PROL})$.

Estimates of general combining ability (GCA) and specific combing ability (SCA) were computed according to Griffing's (1956) method 4, model I, for all traits. The RFLP molecular marker analyses were made by using 88 DNA clones and 4 restriction enzymes, from which 1,429 polymorphic bands were scored. From these data the genetic distance (GD) between all pairs of lines were computed. Estimates of SCA and GD were used for principal coordinate analyses (PCO) and for cluster analyses, by using UPGMA clustering algorithm, to assign the lines to heterotic groups.

For the trait GY the lines were allocated to 4 heterotic groups from the estimates of SCA, in which the lines from each population were subdivided in 2 heterotic groups. From the RFLP data the lines were also allocated at 4 heterotic groups, and, also, the lines from each population were subdivided in 2 heterotic groups. The heterotic groups 
obtained from CEC analyses and from RFLP analyses were quite similar, indicating that the use of molecular markers to assign lines to heterotic groups can be efficient. For the other traits, the use of the estimates of CEC to assign lines to heterotic groups were not efficient.

The results showed that RFLP molecular markers was as efficient as analyses of the CEC estimates for the trait GY in allocating maize lines to heterotic groups. Thus, as grain yield is the main trait for the breeding purposes, RFLP markers can be efficiently used to assign maize lines to heterotic groups, avoiding the need to obtain the crosses and their evaluation in replicated experiments, as well as the statistical analyses of the experiments. Then, the time usually need to allocate maize lines to correct heterotic groups can be considerably reduced by replacing the diallel analysis procedure by the RFLP maker analysis . 


\section{INTRODUÇÃO}

O fenômeno da heterose tem sido extensivamente explorado no melhoramento de milho via produção de híbridos, resultando em plantas mais vigorosas e produtivas. A divergência genética entre as linhagens endogâmicas, que é função das diferenças de frequências alélicas entre estas, determina a magnitude da heterose que é expressa em seus cruzamentos, isto é, nos híbridos.

A utilização de padrões heteróticos em programas de melhoramento visando a obtenção de híbridos de milho constitui uma estratégia que permite explorar e capitalizar a heterose, além de usar de forma mais eficiente o germoplasma disponível para a geração de combinações híbridas superiores (Terron et al., 1997).

As linhagens derivadas de fontes com padrões heteróticos definidos tendem a complementar-se, maximizando a resposta heterótica do híbrido. Após determinar os padrões heteróticos em um programa de melhoramento, pode-se otimizar e incrementar a resposta heterótica através da seleção. Dentre os métodos destinados a avaliar a divergência genética das linhagens, citam-se as análises de cruzamentos dialélicos, que avaliam as capacidades geral e específica de combinação das linhagens (Hallauer et al., 1988; Hallauer, 1990).

Nos programas de melhoramento, o uso de cruzamentos dialélicos é restrito devido às dificuldades de se realizar todos os cruzamentos possíveis entre as linhagens oriundas de grupos heteróticos diferentes. Usualmente, as linhagens de um grupo heterótico são avaliadas em cruzamentos com algumas linhagens elites derivadas de outro grupo heterótico. Com isso, perde-se a oportunidade de se avaliar todos os híbridos possiveis (Smith, 1986). 
$O$ uso de marcadores moleculares na determinação da divergência entre linhagens parentais tem sido proposto com o objetivo de minimizar o grande número de cruzamentos que são necessários para a avaliação das linhagens. As linhagens endogâmicas podem ser alocadas em grupos heteróticos distintos a partir de estimativas da divergência genética entre estas através de marcadores moleculares. Em germoplasma de milho temperado, esta técnica tem se mostrado eficiente para se detectar relações entre linhagens e alocá-las em grupos heteróticos já estabelecidos (Smith et al., 1990; Dudley et al., 1991; Melchinger et al., 1991; Messmer et al., 1992).

$\mathrm{O}$ uso de marcadores moleculares para alocar linhagens a grupos heteróticos distintos pode permitir a manipulação de uma quantidade maior de linhagens e com melhor eficiência. Entretanto, como o uso de cruzamentos dialélicos tem sido eficiente para detectar divergências genéticas entre linhagens e a alocação destas em grupos heteróticos distintos, é necessário se estabelecer a relação entre estas metodologias.

Assim, os objetivos deste trabalho foram:

a) alocar as linhagens de milho em grupos heteróticos distintos utilizando-se de marcadores moleculares do tipo RFLP e de estimativas de capacidades específicas de combinação;

b) comparar a eficiência desses procedimentos. 


\section{REVISÃO DE LITERATURA}

\subsection{Grupos heteróticos}

Os grupos heteróticos foram estabelecidos ao se relacionar a heterose observada nos cruzamentos com a origem dos genitores nesses cruzamentos. Grupos de materiais que combinam bem com os outros são chamados de grupos heteróticos. $\mathrm{O}$ uso da heterose no melhoramento de milho tem sido explorado desde que Shull (1909) sugeriu o conceito de linhas puras. $\mathrm{O}$ estabelecimento de padrões heteróticos entre populações é fundamental para a seleção de linhagens com potencial para produção de híbridos. Normalmente, os grupos heteróticos são estabelecidos baseando-se em cruzamentos com algumas linhagens elites (teste crosses) ou baseando-se nas estimativas de capacidades geral (CGC) e específica (CEC) de combinação obtidas a partir da análise de cruzamentos dialélicos. Porém, através desses procedimentos torna-se impossível a realização de todos os cruzamentos. Uma alternativa para aumentar a eficiência desse processo seria a alocação das linhagens em grupos heteróticos utilizando-se marcadores moleculares.

A manifestação da heterose depende da divergência genética dos parentais e do tipo de ação gênica envolvida no caráter. A divergência genética das cultivares é inferida do padrão heterótico manifestado em uma série de cruzamentos. Se a heterose manifestada no cruzamento é alta, conclui-se que duas cultivares são geneticamente mais divergentes do que duas cultivares que manifestam pequena ou nenhuma heterose em 
seus cruzamentos (Hallauer \& Miranda Filho, 1988). Moll et al. $(1962,1965)$ e Paterniani \& Lonnquist (1963) mostraram uma relação positiva entre distância genética, medida por distância geográfica, e tanto produção de grãos na $F_{1}$ como heterose na produção de grãos na cultura do milho. Os autores relataram que a magnitude da heterose medida nos cruzamentos entre populações e raças de diferentes regiões geográficas aumentou quando a distância genética entre elas aumentou. Porém, os cruzamentos das populações muito divergentes não apresentaram alta heterose.

Os padrões heteróticos são importantes para os melhoristas de milho, mas parece que eles foram estabelecidos de maneira sistemática. Eles foram estabelecidos empiricamente relacionando a heterose observada nos cruzamentos com a origem dos parentais neles incluídos. Os padrões heteróticos não foram desenvolvidos num sentido evolutivo, mas ocorreram por causa da seleção, artificial e natural, que tem ocorrido no desenvolvimento de cultivares de polinização aberta (Hallauer et al., 1988).

Após os grupos heteróticos serem estabelecidos, é feito seleção para aumentar e otimizar a resposta heterótica. A escolha do grupo heterótico depende do desempenho dos híbridos obtidos de linhagens derivadas das respectivas populações fontes. $\mathrm{O}$ reconhecimento e uso de grupos heteróticos têm contribuído para a eficiência e o sucesso nos programas de melhoramento de milho (Gerdes \& Tracy, 1993). Existem vários grupos heteróticos que já foram identificados em milho. Baseando-se em avaliações de teste crosses de raças tropicais, Goodman (1985) relatou a existência de dez grupos heteróticos identificados e explorados pelos melhoristas de milho nas regiões tropicais.

$\mathrm{O}$ padrão heterótico Reid Yellow Dent $\mathrm{x}$ Lancaster Sure Crop tem sido muito usado em programas de melhoramento na região do cinturão do milho nos Estados Unidos e parte do sudeste da Europa. Os padrões heteróticos não estão limitados apenas ao cinturão do milho nos Estados Unidos. Eles também são considerados em outras áreas de importante produção de milho no mundo, onde parecem ter surgido da mesma maneira que ocorreu nos Estados Unidos. Na Europa, um padrão heterótico comum inclui linhagens de milho dentado dos Estados Unidos cruzadas com linhagens de milho duro da Europa (Hallauer et al., 1988). 
A identificação de novos grupos heteróticos foi reconhecida como uma maneira de ampliar a base genética do germoplasma de milho. Vários pesquisadores estão determinando e avaliando grupos heteróticos em diferentes populações de milho visando principalmente a obtenção de cruzamentos superiores. Esses grupos heteróticos são formados baseando-se na genealogia e principalmente nas capacidades geral (CGC) e específica (CEC) de combinação entre as populações. Nos materiais de clima temperado a genealogia é bem conhecida (Gerdes \& Tracy, 1993), porém, nos materiais tropicais a genealogia não é muito clara, pelo fato delas serem originadas por uma mistura de diferentes populações (Naspolini F $^{0}$ et al., 1981; Vasal et al., 1992a).

Devido ao grande uso do padrão heterótico Reid $x$ Lancaster e à estreita base genética do germoplasma de milho nos Estados Unidos, Mungoma \& Pollak (1988) avaliaram as combinações heteróticas entre sete populações de endosperma amarelo, entre três populações de endosperma branco e entre todas as dez populações, com o objetivo de identificar combinações heteróticas iguais ou superiores aos padrões heteróticos Reid $\mathrm{x}$ Lancaster. Os resultados mostraram que algumas populações poderiam ser usadas juntamente com o padrão heterótico Reid x Lancaster. $\mathrm{O}$ cruzamento das populações Mexican Dent $x$ BSSS(R)10 foi superior ao cruzamento BSSS(R) 10 x Lancaster, o qual representa o padrão Reid x Lancaster, indicando que a população Mexican Dent poderia ser avaliada em combinações híbridas como uma alternativa à Lancaster.

Misevic (1989) também identificou novos grupos heteróticos dentro do germoplasma de milho das regiões temperadas e do germoplasma exótico adaptado. Seis populações dos Estados Unidos, três da Iugoslávia, duas exóticas e duas parcialmente exóticas foram cruzadas em um esquema dialélico. $\mathrm{O}$ autor concluiu que duas populações dos Estados Unidos (BS11(FR)C7 e BSSS(R)7) e duas da Iugoslávia (ZPSIN1C] e ZPEP) poderiam ser usadas como alternativa ao padrão heterótico Reid x Lancaster.

Crossa et al. (1990) realizaram um estudo para verificar o padrão heterótico entre 25 raças mexicanas de milho, as quais foram avaliadas em três ambientes identificados como de elevada, intermediária e baixa altitude. Em ambientes de alta elevação, as raças 
Cónico, Cónico Norteño e Chalqueño tinham altas médias de produção per se e em cruzamentos. Cacahuacintle e Maíz Dulce apresentaram alta produção em cruzamentos, mas baixa produção per se. Em elevação intermediária, as melhores produções em cruzamentos e per se foram Comiteco, Harinoso de Ocho, Celaya, Maíz Dulce, Tabloncillo e Tuxpeño. Em baixa elevação, as maiores produções per se foram obtidas por Harinoso de Ocho, Celaya, Pepitilla e Tabloncillo. Considerando-se todas as elevações, as raças que se combinaram melhor foram Cacahuacintle, Harinoso de Ocho e Maíz Dulce.

Visando a utilização de germoplasma tropical nos programas de melhoramento das regiões temperadas, Pollak et al. (1991) compararam padrões heteróticos entre as populações Caribe Flint e Caribe Dent, que são adaptadas às regiões tropicais e têm potencial para serem utilizadas em áreas temperadas, com outras duas populações resultantes do cruzamento de material temperado $\mathrm{x}$ tropical. A melhor combinação heterótica entre as quatro populações foi verificada no cruzamento Caribe Flint $x$ Dent. Os resultados indicaram que as populações Caribe Flint e Dent seriam úteis para o melhoramento de milho na região do cinturão do milho nos Estados Unidos.

Michelini \& Hallauer (1993) realizaram um estudo com o objetivo de verificar a utilização de germoplasma exótico para aumentar a variabilidade genética no milho de regiões temperadas e também para determinar padrões heteróticos entre populações exóticas e populações do cinturão do milho nos Estados Unidos. Os autores concluíram que o padrão heterótico Suwan-1 e Tuxpeño tem potencial para uso nos programas de melhoramento e que essas populações poderiam tanto ser intercruzadas com grupos heteróticos adaptados como ser incluídas em programas de seleção que utilizam germoplasma exótico e adaptado.

Sinobas \& Monteagudo (1996) avaliaram a capacidade de combinação de cultivares de milho provenientes da Espanha em cruzamentos com Reid Yellow Dent (BS13) e Lancaster Sure Crop (Composto A). Sete populações espanholas e duas americanas foram avaliadas em cruzamentos dialélicos. O cruzamento BS $13 \times$ Composto A tinha menor produção do que determinados cruzamentos das populações espanholas $x$ 
BS13. A maior produção foi proveniente do cruzamento BS13 x Andaluz, o qual fornece uma alternativa para estabelecer um padrão heterótico para programas de melhoramento de milho na Espanha.

Spaner et al. (1996) estudaram a capacidade de combinação e padrões heteróticos entre variedades de milho de polinização aberta. Observaram razoável nível de heterose e capacidade específica de combinação para a produção de grãos em alguns cruzamentos. O híbrido das variedades SA-3 x ICTA foi selecionado como a base para formar uma população para ser utilizada em programas de melhoramento em Trinidad.

Péres-Velasquez et al. (1995) realizaram um estudo para identificar novos padrões heteróticos e avaliar o potencial de cinco raças de milho da Colômbia (Andaquí, Cumún, Costeño, Puya e Yucatán) e três populações de milho melhoradas (Tuxpeño-1, Suwan-1 e ETO), bem como fornecer informações sobre as relações entre esses materiais. Os resultados indicaram a raça Yucatán como uma fonte de recursos genéticos para ser utilizada em programas de melhoramento de milho tropical.

$\mathrm{Na}$ lugoslávia os padrões heteróticos explorados são principalmente entre material local e linhagens introduzidas, mas a heterose somente no material local não tem sido utilizada. Radovic \& Jelovac (1995) avaliaram 126 variedades de polinização aberta da Iugoslávia em cruzamento com as populações Mol7 (Lancaster) e B73 (Reid) e com a linhagem local V395/31. Os autores verificaram que as populações apresentaram heterose em relação as três fontes utilizadas (Lancaster, Reid e linhagem local) e concluíram que alguns grupos de populações são heteróticos entre si. Considerando a vantagem adaptativa do material local, o padrão heterótico entre materiais adaptados seria muito promissor nos programas de melhoramento de milho na lugoslávia.

Gama et al. (1995) estudaram a possibilidade de utilização de linhagens relacionadas na formação de um padrão heterótico. Para isso, avaliaram 11 linhagens $S_{3}$ da população de milho Tuxpeño em cruzamentos. Encontraram estimativas de capacidade geral de combinação (CGC) positivas e negativas entre as linhagens. Verificaram, também, que alguns cruzamentos apresentaram efeitos positivos e significativos da capacidade específica de combinação (CEC). As linhagens 6 e 7 apresentaram efeitos 
positivos de CGC altamente significativos e mostraram potencial para a utilização como parentais para híbridos triplos e duplos.

Trabalhando com populações de milho doce, Revilla \& Tracy (1997) realizaram um estudo para definir padrões heteróticos entre algumas cultivares de importância histórica. Seis cultivares foram avaliadas em um esquema de cruzamentos dialélicos e estimativas de heterose e capacidade de combinação foram obtidas. Os resultados indicaram a formação de dois padrões heteróticos, sendo um mais forte e outro mais fraco. Esses resultados concordam com os dados da análise da genealogia (Tracy, 1990) e com a classificação baseada em distâncias bioquímicas e morfológicas (Gerdes \& Tracy, 1994; Revilla \& Tracy, 1995a).

San Vicente et al. (1998) avaliaram nove populações de milho tropical com o objetivo de determinar a capacidade de combinação e os padrões heteróticos entre elas. Foram encontradas combinações superiores entre os materiais com tipo de grão duro $\mathrm{x}$ dentado. Entretanto, dois cruzamentos envolvendo combinações de grãos duros (CD77 x CD91 e CD77 $\times$ NB12) estiveram entre os cinco mais produtivos e também tinham efeitos significativos de CEC. O cruzamento P49 x NB12 superou o P49 x P32, o qual representa o tradicional padrão heterótico Tuxpeño x ETO. Os autores concluíram que a população NB12 poderia ser avaliada em combinações híbridas com P49 como uma alternativa à P32. Através dos resultados foram identificados novos padrões heteróticos que poderiam ser posteriormente avaliados e melhorados por seleção recorrente.

Souza Jr. et al. (1993) avaliaram o potencial genético das populações de milho BR-105 e BR-106 visando o melhoramento interpopulacional e relataram que essas populações mostraram alta heterose no cruzamento, indicando que pertencem a grupos heteróticos opostos. As populações também apresentaram elevada produtividade per se. Os resultados indicaram que as populações possuem elevado potencial para serem utilizadas em programas de seleção recorrente recíproca e para a obtenção de híbridos de linhagens. 
Utilizando-se a informação da genealogia, Gerdes \& Tracy (1993) examinaram a diversidade presente em 37 linhagens do grupo heterótico Lancaster e verificaram a evolução destas linhagens até o presente momento. Observou-se que o germoplasma Lancaster presente nas linhagens que hoje estão incluídas no moderno grupo heterótico Lancaster foi derivado de duas linhagens, Oh40B e C103. Além disso, a quantidade de verdadeiro Lancaster é de $50 \%$ ou menos em 36 dessas linhagens, com mais de 20 fontes de germoplasma não Lancaster contribuindo para esse grupo heterótico. Os autores concluíram que o grupo heterótico Lancaster tem sido modificado consideravelmente, com uma redução no germoplasma original e um aumento de germoplasma exótico, incluindo o Reid Yellow Dent.

Em 1985 iniciou-se o programa de melhoramento de milho do CIMMYT (Centro Internacional de Melhoramento de Milho e Trigo) visando a obtenção de híbridos, sendo que o objetivo primário era caracterizar o padrão heterótico e a capacidade de combinação das populações e dos conjuntos gênicos da própria instituição. As populações das regiões tropicais e subtropicais possuem ampla base genética e têm sido melhoradas através de testes em vários locais. Entretanto, faltam informações sobre a heterose e a capacidade de combinação dos cruzamentos das populações de diferentes adaptações (Vasal et al., 1992a).

Naspolini $\mathrm{F}^{\mathrm{o}}$ et al. (1981) avaliaram o desempenho de várias populações tropicais e subtropicais do CIMMYT e duas populações brasileiras utilizando-se análise de cruzamentos dialélicos. Entre os materiais subtropicais, a população 42 demonstrou o mais alto efeito de CGC para peso de espigas, seguida pela população 33.

Beck et al. (1991) e Vasal et al. (1992a) estudaram a capacidade de combinação de populações temperadas e subtropicais do CIMMYT e o potencial destas populações como fontes de germoplasma exótico para programas de melhoramento de milho. Beck et al. (1991) observaram efeitos positivos de CGC para produção nas populações 42, 47 e 34 , as quais são materiais subtropicais de maturação intermediária. O cruzamento envolvendo as populações 42 e 47 foi o mais produtivo quando avaliado no México. Sob condições dos Estados Unidos, entretanto, somente a população Pool 41, que tinha mais 
germoplasma temperado, mostrou efeito positivo de CGC para produção. Os autores concluíram que Pool 41 e a população 42 mostraram os melhores potenciais como fontes de germoplasma exótico para programas de melhoramento em regiões temperadas. Os resultados com germoplasma subtropical e temperado testados em 17 ambientes temperados e 5 ambientes tropicais (Vasal et al., 1992a) mostraram que as populações 48 e Pool 30 se comportaram melhor sob ambientes temperados e poderiam ser utilizadas como fonte de germoplasma exótico no cinturão do milho nos Estados Unidos.

A utilidade do germoplasma de milho para o desenvolvimento de híbridos também foi demonstrada por Han et al. (1991), os quais identificaram vários hibridos de alta produção nos cruzamentos envolvendo linhagens $S_{3}$ derivadas de Pools e populações do CIMMYT. Muitos híbridos intrapopulacionais superiores foram identificados juntamente com híbridos interpopulacionais.

O cruzamento de germoplasma de milho de diferentes grupos de adaptações poderia resultar na melhor utilização do vigor do híbrido, porém, tal resposta heterótica raramente é explorada devido a problemas na adaptação de alguns materiais. Vasal et al. (1992b) verificaram o efeito da heterose e da capacidade de combinação entre germoplasma de milho tropical e subtropical do CIMMYT avaliado em diversos ambientes. Os três cruzamentos mais produtivos em todos os ambientes (populações $43 \times 42,32 \times 44$ e $22 \times 47$ ) mostraram também alta heterose. Verificou-se que a população 43 do germoplasma tropical e as populações 42 e 44 do germoplasma subtropical, mostraram efeitos positivos de CGC para produção, indicando que ambas são ideais para o desenvolvimento de híbridos. Os resultados demonstram o considerável potencial que existe para o melhoramento de germoplasma subtropical através de cruzamentos com material tropical. Vasal et al. (1993a,b) realizaram um estudo para determinar a capacidade de combinação e padrões heteróticos para os caracteres produção de grãos e modificação do endosperma em germoplasma tropical e subtropical com alta qualidade proteica (QPM). O estudo dialélico envolvendo o germoplasma QPM tropical do CIMMYT mostrou que cruzamentos entre parentais de endosperma branco apresentaram-se melhores do que cruzamentos entre parentais de endosperma amarelo. 
Cruzamentos entre milho dentado e dentado $\mathrm{x}$ duro, foram melhores do que cruzamentos entre milho duro. Baseando-se na capacidade geral e específica de combinação, os autores concluíram que as populações 62 e 63 entre os materiais de endosperma branco e a população 65 entre os de endosperma amarelo, poderiam ser usadas para iniciar um programa de desenvolvimento de híbridos. Os resultados do germoplasma QPM subtropical indicaram o comportamento diferenciado das populações quando avaliadas em ambientes no México e nos Estados Unidos. Verificou-se que a alta heterose sob condições dos Estados Unidos poderia ser explorada em cruzamentos envolvendo populações precoces. Observou-se, também, que para condições subtropicais, as populações 68 QPM, 32 QPM, 69 QPM e 34 QPM tinham potencial para um programa de híbridos.

Gonzalez et al. (1997) avaliaram 45 híbridos simples provenientes de cruzamentos dialélicos de dez linhagens de milho subtropical do CIMMYT. Os melhores cruzamentos foram entre as linhagens $5 \times 10,5 \times 8,5 \times 6,4 \times 10$ e $5 \times 7$, com rendimentos aproximados de $11 \mathrm{t} / \mathrm{ha}$. Com base na capacidade específica de combinação, as linhagens foram alocadas em grupos heteróticos A e B. As linhagens 1, 4, 5 e 6 ficaram no grupo heterótico $\mathrm{A}$ e as linhagens $2,3,7,8,9$, e 10 no grupo heterótico $\mathrm{B}$. Os autores sugeriram que a linhagem 5 seja utilizada como testadora de A e a linhagem 10 como testadora de B.

Com o objetivo de determinar a capacidade de combinação e padrões heteróticos em linhagens de milho tropical para identificar e formar grupos heteróticos, Vasal et al. (1992c) utilizaram 92 linhagens de milho tropical com diferentes níveis de endogamia $\left(S_{3}\right.$ a $\mathrm{S}_{6}$ ), as quais foram obtidas de nove populações de milho tropical do CIMMYT. As 92 linhagens foram cruzadas com quatro testadores (dois de milho dentado e dois de milho duro) e a capacidade geral de combinação (CGC) foi calculada a partir das análises das linhagens $x$ testadores. Baseando-se na CGC para produção, o testador 1 (população 21 dentado) e o testador 3 (população 25 - duro) foram selecionados. As 92 linhagens foram classificadas em dois grupos heteróticos, sendo o Grupo Heterótico Tropical A (a maioria das linhagens era de milho dentado) e o Grupo Heterótico Tropical B (a maioria das 
linhagens era de milho duro). As linhagens de cada grupo foram recombinadas para a formação de dois novos grupos heteróticos. Essas duas novas populações devem exibir alto nível de heterose entre elas e poderiam servir como fonte de germoplasma para a produção de híbridos. Trabalho semelhante foi realizado por Vasal et al. (1992d), no qual utilizaram 88 linhagens oriundas de seis populações de milho subtropical. As 88 linhagens foram cruzadas com quatro testadores (T1: pool 32, T2: população 44, T3: população 42 e T4: população 34), sendo que a partir destes cruzamentos 42 linhagens foram incluídas no Grupo Heterótico Subtropical A e 44 linhagens no Grupo Heterótico Subtropical B.

Terron et al. (1997) cruzaram 30 linhagens selecionadas da população 43 SR do CIMMYT com os testadores CML-320 (grupo heterótico A) e CML-321 (grupo heterótico B) que deram 60 combinações linhagens $\mathrm{x}$ testadores. O objetivo deste trabalho era determinar o padrão heterótico das 30 linhagens, identificar os cruzamentos superiores, selecionar as linhagens com boa capacidade de combinação e formar sintéticos integrados por linhagens de acordo com sua resposta ao padrão heterótico. Em estudos anteriores, Vasal et al. (1992a) relataram que as linhagens provenientes da população 43SR se classificaram no grupo heterótico A, razão pela qual se esperava que a maior parte destas 30 linhagens fizessem parte desse grupo heterótico. Porém, o comportamento foi um pouco diferente. Baseando-se na capacidade de combinação, as linhagens $1,5,7,17,18$ e 19 se classificaram no grupo heterótico A e as linhagens 11 , $16,22,25$, e 28 foram alocadas no grupo heterótico B. Estes resultados mostram que é possivel retirar linhagens e formar híbridos interpopulacionais das populações do CIMMYT, devido suas constituições serem de ampla base genética.

Outra maneira de se avaliar a divergência genética entre as populações é através do uso de técnicas multivariadas. As técnicas multivariadas baseadas nas múltiplas informações fenotípicas, relacionando as diferenças morfológicas têm sido amplamente utilizadas (Cruz, 1990; Cruz et al., 1994b). Llauradó \& Moreno-Gonzalez (1993) classificaram 86 populações de milho representantes das regiões norte e nordeste da Espanha. Foram analisados os dados de 23 características utilizando técnicas multivariadas. As populações foram agrupadas através do grau de dissimilaridade em 
quatro grupos distintos relacionados às quatro áreas geograficamente ou climaticamente delineadas. Os resultados foram contrastantes com os dados da análise isoenzimática (Llauradó et al., 1993).

Cruz et al. (1994a) avaliaram a divergência genética de cinco cultivares comerciais de milho (Piracar I, WP17, WP24, WP25 e WP33) e a eficiência da predição do comportamento dos híbridos utilizando-se análises multivariadas. As cultivares WP24 e WP33 foram as mais similares, sendo a cultivar WP25 a mais divergente em relação as demais. Os resultados mostraram também que a predição do comportamento dos híbridos foi satisfatória, principalmente em termos de rendimento de grãos.

As técnicas multivariadas também foram utilizadas por Ferreira et al. (1995) para estimar a divergência genética em 28 variedades de milho de diferentes origens. As 28 variedades foram avaliadas isoladamente nas gerações $S_{0}$ e $S_{1}$ e também em combinações híbridas através de um cruzamento dialélico. Verificou-se que a avaliação da divergência genética realizada a priori nessas populações, evitaria a realização da maioria dos cruzamentos, com redução no custo e melhoria na precisão das avaliações.

Revilla \& Tracy (1995a) utilizaram 34 descritores para a caracterização morfológica das 58 cultivares de milho doce avaliadas utilizando-se técnicas multivariadas. O objetivo desse estudo foi fornecer informações aos melhoristas interessados em ampliar a base genética das populações de milho doce. Observou-se que 52 cultivares foram consideradas de uma única raça, chamada de Northeastern Sweets. Outras cinco cultivares foram classificadas como sendo do centro-norte ou do sudeste dos Estados Unidos. A última é uma importante cultivar comercial chamada de Country Gentleman. Os resultados obtidos concordaram com os dados da análise isoenzimática (Revilla \& Tracy, 1995b).

Fuzatto (1999) realizou um estudo para verificar a divergência genética de 25 cultivares de milho utilizadas no Sul do Estado de Minas Gerais através de métodos multivariados e também, para verificar se as informações fornecidas pelos métodos multivariados no estudo da divergência são semelhantes aos dos cruzamentos dialélicos. A análise multivariada permitiu a formação de seis grupos divergentes. Nem todas as 
distâncias estimadas pela análise multivariada apresentaram-se compatíveis com os resultados da análise dialélica, havendo coincidência somente entre as 30 combinações híbridas de maior heterose. A correlação entre distância de Mahalanobis e a heterose, embora de baixa magnitude, foi altamente significativa.

Utilizando-se os dados existentes na Embrapa Milho e Sorgo sobre estudos de cruzamentos dialélicos em 170 populações de milho, Nass et al. (2000) sintetizaram quatro grupos heteróticos (GN-01, GN-02, GN-03 e GN-04) considerando-se as melhores estimativas de capacidade geral de combinação e buscando maximizar a heterose em cruzamentos. Os resultados da avaliação dos compostos indicaram que esses são fontes promissoras para utilização como populações base nos programas de melhoramento de milho.

Observa-se que os padrões heteróticos são de fato muito importantes para os melhoristas de milho, pois permitem o uso mais eficiente do germoplasma. As linhagens de fontes com padrões heteróticos definidos tendem a complementar-se, maximizando a resposta heterótica do híbrido. Alguns dão mais ênfase do que outros aos padrões heteróticos. Alguns padrões heteróticos foram usados no passado e continuam a ser considerados, entretanto, outros serão identificados (Gerrish, 1983).

\subsection{Cruzamentos dialélicos}

Cruzamentos dialélicos correspondem ao acasalamento de $\mathrm{n}$ progenitores (linhagens, variedades, populações, etc.) resultando em $\mathrm{n}^{2}$ combinações possíveis, as quais correspondem aos $n$ materiais, $n(n-1) / 2$ híbridos simples e $n(n-1) / 2$ recíprocos dos híbridos simples, resultando em uma tabela dialélica completa.

Os cruzamentos dialélicos têm sua origem no desenvolvimento de conceitos de capacidade combinatória geral e específica estabelecidos por Sprague \& Tatum (1942). De acordo com estes autores o termo capacidade geral de combinação (CGC) se emprega para designar o comportamento de uma progênie em combinações híbridas e 
capacidade específica de combinação (CEC) se emprega nos casos em que certas combinações são relativamente melhores ou piores do que se poderia esperar em relação ao comportamento médio das progênies envolvidas. Em relação ao tipo de ação gênica, a CGC está associada principalmente a genes de efeito aditivo e a CEC depende basicamente de genes de efeito dominante.

Nos programas de melhoramento de milho, o uso de cruzamentos dialélicos é restrito devido às dificuldades de se realizar todos os cruzamentos possíveis entre as linhagens de grupos heteróticos distintos. Quando se tem um dialelo completo, serão incluídos todos os possíveis cruzamentos e parentais. Assumindo-se 10 linhagens em cruzamentos dialélicos, tem-se 90 cruzamentos incluindo os recíprocos e 45 cruzamentos se os recíprocos são ignorados. Se o número de linhagens aumenta, o número de cruzamentos possíveis também aumenta. Após incluir de 10 a 15 linhagens, o número de cruzamentos feitos e avaliados torna-se quase impraticável. Portanto, torna-se claro que o número de linhagens que se pode incluir em um esquema de cruzamentos dialélicos é um fator limitante (Hallauer \& Miranda Filho, 1988).

No início do melhoramento do milho, a avaliação da capacidade de combinação das linhagens era determinada cruzando-se linhagens individuais com o maior número possível de outras linhagens. Considerando-se que $n(n-1) / 2$ diferentes híbridos simples podem ser obtidos a partir de $\mathrm{n}$ linhagens, esse sistema de avaliação se tornou impraticável (Allard, 1960). Posteriormente, Davis (1927) e Jenkins \& Brunson (1932) sugeriram o uso de teste crosses, que permite o cruzamento de um grande número de linhagens com um testador comum. Entretanto, o sistema teste crosses permite somente a estimação da capacidade de combinação com o testador, mas não fornece a informação sobre a CEC para cruzamentos específicos dentro do conjunto de linhagens. Além do mais, o efeito da capacidade de combinação de uma linhagem não é uma propriedade dela por si só, mas depende do conjunto de linhagens com o qual ela será cruzada (Kempthorne \& Curnow, 1961). Assim, a capacidade geral de combinação de uma linhagem no esquema de cruzamentos dialélicos poderia não ser necessariamente a 
mesma capacidade de combinação em cruzamentos com um testador comum (teste crosses).

Os cruzamentos dialélicos têm sido muito usados no melhoramento de milho e se mostrado eficientes para detectar divergências genéticas entre as linhagens e a alocação destas em grupos heteróticos distintos. Após feitos os cruzamentos, avaliações e análises, podem ser feitas inferências sobre o tipo de ação gênica (Griffing, 1956). Existem várias metodologias para análise de cruzamentos dialélicos, sendo que as mais empregadas são as metodologias de Hayman (1954a, b), Gardner \& Eberhart (1966) e Griffing (1956).

A metodologia proposta por Hayman (1954a, b) fornece informações sobre o mecanismo básico da herança do caráter em estudo, dos valores genéticos dos progenitores utilizados e do limite de seleção. A utilização dessa metodologia é possível apenas com linhagens puras, sendo assim, muito utilizada em plantas autógamas.

A metodologia apresentada por Gardner \& Eberhart (1966) é especifica para cruzamentos dialélicos entre variedades em equilibrio de Hardy-Weinberg (Vencovsky, 1970). Essa metodologia permite estudar as propriedades genéticas das populações a partir de médias e não de variâncias. São avaliados os efeitos de variedades e heterose varietal. Vencovsky (1969) fornece as variâncias das estimativas dos parâmetros genéticos do modelo, bem como a interpretação da análise da variância de acordo com as diferentes significâncias do modelo.

Griffing (1956) apresentou uma metodologia pela qual são estimados os efeitos e as somas de quadrados dos efeitos da capacidade geral e específica de combinação. Essa metodologia é classificada em quatro métodos experimentais: Método 1: são incluídas as $n^{2}$ combinações (genitores, $F_{1}{ }^{\prime} s$ e recíprocos); Método 2: são incluídas $n(n+1) / 2$ combinações, faltando os híbridos $F_{1}$ 's recíprocos; Método 3: são incluídas $n(n-1)$ combinações, faltando os genitores e Método 4: são incluídas n(n-1)/2 combinações, faltando os genitores e os híbridos $F_{1}$ 's recíprocos.

Os vários métodos de análises de dados dos cruzamentos dialélicos são baseados em princípios estatísticos. Portanto, na realização das análises, deve-se levar em consideração a natureza dos dados, ou seja, se os parentais são considerados como uma 
população sobre a qual as inferências serão feitas (modelo fixo) ou como uma amostra ao acaso de alguma grande população de parentais (modelo aleatório). Segundo Griffing (1956), na análise baseada no modelo fixo, somente poderão ser feitas comparações das capacidades de combinação dos parentais utilizados no experimento e a identificação das combinações superiores. Na análise baseada no modelo aleatório, as inferências serão feitas sobre a população da qual os parentais foram amostrados e estas inferências são feitas das estimativas dos componentes da variância. Apesar das análises de variância serem muito similares em ambos os modelos, os parâmetros testados nos dois modelos são diferentes (Baker, 1978). Griffing (1956) desenvolveu suas análises para ambos os modelos e, em um exemplo, sugeriu que a escolha do modelo correto dependia da natureza do material parental.

Visando reduzir o número de cruzamentos a serem feitos, Kempthorne \& Curnow (1961) sugeriram o método do cruzamento dialélico parcial circulante, o qual permite a avaliação de um maior número de linhagens em cruzamentos. De acordo com este esquema de cruzamento, cada uma das $\mathrm{n}$ linhagens de um conjunto são cruzadas com outras s linhagens do mesmo conjunto, ao invés de (n-1) linhagens como ocorre no dialelo completo. Então, serão ns/2 cruzamentos no total, em que $s \geq 2$. Os cruzamentos são realizados de tal modo que todas as linhagens estão envolvidas na amostra de cruzamentos.

\subsection{Marcadores moleculares}

A determinação da divergência genética entre linhagens, populações e raças de milho pode ser baseada em dados genealógicos, heterose, características morfológicas, ou também, através de marcadores moleculares tais como isoenzimas, RFLP (polimorfismo no comprimento de fragmento de restrição), RAPD (polimorfismo de DNA amplificado ao acaso) e AFLP (polimorfismo no comprimento de fragmento amplificado). Os marcadores moleculares permitem gerar grande quantidade de informações sobre a 
diversidade genética e relacionamentos filogenéticos no germoplasma utilizado pelo melhorista (Ferreira \& Grattapaglia, 1995).

$\mathrm{O}$ uso de marcadores moleculares na determinação da divergência das linhagens seria uma alternativa para minimizar o grande número de cruzamentos nos programas de melhoramento de milho. Com a separação das linhagens em grupos heteróticos, são feitos apenas cruzamentos entre linhagens que estão em grupos heteróticos distintos, evitando os cruzamentos desnecessários. Dados morfológicos têm sido usados tradicionalmente na proteção e registro de cultivares com o objetivo de identificar e distinguir essas cultivares. Entretanto, caracteres morfológicos geralmente não são medidas seguras da relação genética devido às interações ambientais e o desconhecido controle genético dessas características (Melchinger et al., 1991). Dados bioquímicos obtidos por isolamento de proteínas pelo uso de eletroforese fornecem melhor descrição do genótipo porque eles não são significativamente afetados pelo ambiente e suas bases genéticas geralmente são bem compreendidas (Smith \& Smith, 1987).

Muitas das complicações da análise fenotípica podem ser atenuadas através da identificação direta de genótipos. Cada indivíduo possui uma seqüência característica de nucleotídeos que compõe o seu DNA. A detecção das diferenças entre essas seqüências, seja através de polimorfismo de fragmentos de DNA ou polimorfismo isoenzimático, revela um padrão único, uma impressão digital genética que pode ser utilizada na identificação (Ferreira \& Grattapaglia, 1995).

Alguns pesquisadores utilizaram isoenzimas para verificar as similaridades e relações de diversas populações de milho. Goodman \& Stuber (1983) avaliaram a variação entre 31 raças de milho da Bolívia por meio de análises de componentes principais e de agrupamento, mostrando que a maioria do material adaptado às regiões de altitudes elevadas formou um agrupamento consistente. Os resultados concordaram com os estudos prévios das raças de milho da Bolívia e foram consistentes com os estudos citológicos dos cromossomos. Doebley et al. $(1983,1985)$ confirmaram a correspondência entre os dados de isoenzimas e localização geográfica nas coleções de milho do sudoeste dos Estados Unidos e coleções do México detectando alto nível de 
variação entre e dentro das raças mexicanas. Através da análise de isoenzimas em 18 populações do nordeste dos Estados Unidos, Doebley et al. (1986) confirmaram a hipótese previamente publicada, de que os milhos de grãos duros do nordeste foram derivados de raças do sudeste dos Estados Unidos e nordeste do México. Vários outros trabalhos foram realizados com objetivos semelhantes (Doebley et al., 1988; Bretting et al., 1990; Llauradó, 1993; Revilla \& Tracy, 1995b; Revilla et al., 1998).

Os programas de melhoramento visando a produção de híbridos, requerem informações sobre a relação genética entre as linhagens para evitar cruzamentos de linhagens relacionadas. No passado, a distância genética era estimada principalmente através do cálculo do coeficiente de parentesco (f). Entretanto, as estimativas de f podem não refletir a verdadeira relação entre as linhagens devido à seleção e/ou deriva genética durante o seu desenvolvimento (Brunklaus-Jung et al., 1993). Esses autores avaliaram correlações entre estimativas de similaridades genéticas (SG) baseadas em RFLP e o coeficiente de parentesco (f) para 13 linhagens de milho duro e seis linhagens de milho dentado da Europa, concluindo que SG e f fornecem resultados similares na determinação das relações genéticas. Portanto, ambas as medidas são desejáveis para a exclusão de cruzamentos inferiores de linhagens aparentadas.

Messmer et al. (1993) avaliaram 29 linhagens, sendo 18 de milho duro e 11 de milho dentado, do germoplasma da Europa através do coeficiente de parentesco ( $f$ ) e da similaridade genética (SG) baseada em RFLP. A correlação entre f e SG foi altamente significativa para 87 pares de linhagens de milho duro e para 30 pares de linhagens de milho dentado. Os resultados mostraram que SG e f são úteis para identificar linhagens aparentadas.

Anjmone-Marsan et al. (1992) estudaram a utilidade dos marcadores RFLP para determinar as similaridades genéticas de 16 linhagens de milho pertencentes ao grupo heterótico Iowa Stiff Stalk Synthetic (BSSS) e de 15 linhagens do grupo heterótico Lancaster Sure Crop (LSC) e comparar essas similaridades com aquelas baseadas nas informações da genealogia. Os autores relataram que RFLPs são úteis para a 
determinação das relações entre linhagens de milho, verificação dos registros de genealogia e quantificação do grau de parentesco das linhagens.

Os marcadores RFLP e isoenzimas também têm sido utilizados na determinação da divergência genética em diversas populações de milho. Messmer et al. (1991) avaliaram a divergência genética entre 21 linhagens da população de milho Iowa Stiff Stalk Synthetic (BSSS) usando aloenzimas e RFLP. A divergência genética entre as 21 linhagens foi substancialmente maior para RFLP do que para aloenzimas, mas a porcentagem de variantes de RFLP $(27,0 \%)$ e aloenzimas $(25,0 \%)$ nos progenitores BSSS foi similar. As distâncias genéticas entre as linhagens foi, em média, duas vezes maior para $\operatorname{RFLP}(0,51)$ que para aloenzimas $(0,24)$. A análise de componentes principais dos dados de RFLP, em contraste com os dados de aloenzimas, resultou na formação de grupos separados com dez progenitores BSSS derivadas da população Reid Yellow Dent, quatro linhagens elite BSSS e a linhagem Mo17. Os seis progenitores BSSS restantes foram muito diferentes geneticamente. Os resultados desse estudo mostraram que RFLP's são superiores às aloenzimas para a caracterização da diversidade genética em milho, principalmente devido ao número quase ilimitado de marcadores disponíveis e a maior quantidade de polimorfismo encontrado. Burstin et al. (1994) também observaram discrepância entre resultados de RFLP e isoenzimas no estudo da divergência genética de 21 linhagens de milho.

Smith \& Smith (1992) avaliaram a divergência genética em 10 híbridos de milho utilizando dados de distâncias genéticas obtidos por isoenzimas, RFLP, coeficiente de parentesco e distâncias genéticas baseadas na depressão por endogamia na produção de grãos. As distâncias genéticas baseadas na depressão por endogamia foram altamente correlacionadas com as distâncias baseadas no coeficiente de parentesco. As distâncias obtidas por RFLP também foram altamente correlacionadas com o coeficiente de parentesco e com as distâncias baseadas na depressão por endogamia. Os resultados mostraram que ambos os métodos poderiam ser usados para determinar a distância genética entre os híbridos e que essas distâncias concordam com os dados da genealogia. Os autores relataram que os marcadores RFLP são confiáveis, rápidos e econômicos na 
determinação das similaridades genéticas entre os híbridos. A desvantagem dessa técnica ou qualquer outra técnica que não mede diretamente o desempenho agronômico, é que essas técnicas não contribuem com diferenças agronômicas que podem ser importantes na distinção de híbridos geneticamente similares.

Messmer et al. (1992) analisaram através de marcadores do tipo RFLP, 57 linhagens elites pertencentes a grupos heteróticos de milho duro e dentado da Europa. Os pesquisadores pretendiam investigar a quantidade de variação para RFLP's nesses materiais, determinar o nível de divergência genética dentro e entre grupos heteróticos e verificar a utilidade de RFLP's na designação de linhagens a grupos heteróticos. As similaridades genéticas médias para as combinações das linhagens não relacionadas dentro dos grupos heteróticos de milho duro $(0,42)$ e dentado $(0,41)$ foram maiores do que combinações das linhagens duro $\mathrm{x}$ dentado $(0,34)$. A análise de componentes principais resultou em um agrupamento que separou as linhagens de milho duro e dentado. Os resultados mostraram que marcadores de RFLP's são úteis para identificação de linhagens e, também, para designá-las a grupos heteróticos.

Dubreuil et al. (1996) avaliaram 116 linhagens pertencentes a quatro grupos heteróticos (European Flint, Lancaster Sure Crop, Minnesota 13 e Reid Yellow Dent) e de origem diversa, utilizando-se marcadores RFLP. O objetivo desse estudo foi alocar as linhagens em grupos heteróticos e verificar a divergência genética e a estrutura dentro e entre os grupos heteróticos existentes. Através das análises de componentes principais e de agrupamento, as linhagens de grupos heteróticos estabelecidos foram separadas em linhagens de milho duro e dentado. Dentro do germoplasma dos Estados Unidos, a classificação mostrou uma associação do agrupamento das linhagens com as relações da genealogia. Baseando-se nos resultados, observou-se que os marcadores moleculares foram úteis na identificação de grupos heteróticos e para designar as origens das linhagens desconhecidas ou de ampla base genética.

Dubreuil \& Charcosset (1998) realizaram um estudo para comparar o potencial de marcadores RFLP e isoenzimas na determinação da diversidade genética entre e dentro de 10 populações de milho. O número médio de alelos detectados por loco foi maior para 
RFLP que para isoenzimas. Os resultados mostraram que o maior polimorfismo observado para RFLP e o maior número de locos contribuíram para a habilidade discriminativa superior desse marcador.

$\mathrm{O}$ uso de isoenzimas e RFLP também têm sido proposto para prever o desempenho do híbrido a partir da divergência genética das linhagens. Hunter \& Kannemberg (1971) avaliaram a divergência genética em 15 linhagens de milho utilizando isoenzimas e sua relação com o desempenho dos híbridos simples. As diferenças nos sistemas enzimáticos foram usadas para calcular o índice de diversidade (ID). O ID para qualquer par de linhagens representa o número de isoenzimas que foram dissimilares nas duas linhagens. Hibridos com altos IDs produziram mais do que aqueles com baixos IDs. Entretanto, a correlação entre desempenho na produção de grãos dos híbridos simples e ID fòi baixa $(r=0,09)$ e não significativa. Verificou-se portanto, que o ID tinha um valor limitado na predição de híbridos.

Trabalho semelhante foi realizado por Gonela \& Peterson (1978), onde avaliaram a relação entre sete linhagens de milho e a associação com a produção dos híbridos simples. Foi calculado um índice (\% de relação entre as linhagens) baseado nas análises de isoenzimas para avaliar a relação entre as linhagens. A correlação entre a média de produção dos híbridos simples e a \% de relação de suas linhagens foi -0,42. A correlação entre os efeitos da capacidade específica de combinação e a \% de relação entre as linhagens foi $-0,32$, sugerindo uma pequena tendência das linhagens mais distantes combinarem especificamente melhor. Apesar dos valores absolutos não serem grandes, o sinal indica o que seria esperado, ou seja, a maior produção associada com maior diversidade genética. Os autores concluíram que existe pouca ou nenhuma utilidade prática na determinação do grau de relação entre as linhagens usando análise isoenzimática como uma medida para avaliar o desempenho de produção de seus híbridos simples.

Heidrich-Sobrinho \& Cordeiro (1975) utilizaram marcadores codominantes isoenzimáticos para relacionar a divergência genética com heterose em linhagens de milho. Após uma amostragem de oito linhagens e seus cruzamentos dialélicos, verificou- 
se que a média de produção dos $F_{1}$ 's correlacionou-se significativamente com a divergência genética das linhagens parentais calculada a partir de padrões de zimogramas de cinco sistemas enzimáticos. Apesar do pequeno número de locos avaliados neste estudo (oito), os autores concluíram que esses alelos codominantes são bons marcadores para se determinar a heterogeneidade nas linhagens.

Frei et al. (1986) utilizaram aloenzimas como marcadores genéticos para predizer o desempenho de híbridos simples de milho. Uma medida de relação genética entre 406 linhagens e seis testadores foi gerada e os pares de linhagens foram classificados em grupos de aloenzimas similares (AS) e dissimilares (AD). Uma segunda relação genética foi baseada na genealogia. Linhagens derivadas da mesma população foram consideradas como de genealogia similar (GS) e linhagens derivadas de populações diferentes como de genealogia dissimilar (GD). A classe AD apresentou produção mais alta que a classe AS. A classe GD superou a produção da classe GS em 37,0\%. A interação aloenzimas x genealogias mostrou-se altamente significativa, sugerindo a necessidade de uma análise dos efeitos da aloenzima dentro de cada classe de genealogia. Os resultados mostraram que a aloenzima se associou com alta produção somente quando a genealogia foi similar (classe GS). Nos híbridos de linhagens de populações diferentes (classe GD), a aloenzima não mostrou associação com produção, indicando que o potencial das aloenzimas na predição de híbridos é limitado.

Price et al. (1986) avaliaram a relação entre o nível de heterozigosidade entre os locos enzimáticos e o desempenho dos híbridos simples de milho. Apesar da associação entre heterozigosidade dos locos enzimáticos e produção, acamamento e altura da espiga ter sido significativa, os resultados indicaram que o desempenho dos híbridos ao longo dos anos não estava associado com o aumento no número de locos enzimáticos heterozigotos. Então, concluiu-se que as diferenças alélicas dos locos enzimáticos entre linhagens pode não ser um indicador do desempenho heterótico dos híbridos simples de milho. 
Lamkey et al. (1987) avaliaram 45 linhagens de milho, sendo 24 de alta produção e 21 de baixa produção. As linhagens e os híbridos entre as linhagens foram avaliados utilizando-se isoenzimas. $\mathrm{O}$ objetivo do estudo era determinar se as diferenças alélicas poderiam ser usadas para predizer o desempenho do híbrido. Os resultados indicaram que as diferenças nos locos enzimáticos não são indicativos do desempenho do híbrido e que os locos enzimáticos têm utilidade limitada na predição da capacidade combinatória em milho.

Melchinger et al. (1990a) realizaram um estudo utilizando marcadores RFLP para quantificar a variação genética em 20 linhagens de milho, estimar a distância genética baseada em RFLP dentro dos quatro tipos de linhagens (primeiro ciclo, segundo ciclo, linhagens boas e inferiores) e verificar a sua relação com heterose na produção e a utilidade na predição do desempenho dos híbridos simples. A análise de agrupamento revelou a associação entre as linhagens consistente com o esperado baseado no conhecimento da genealogia. As correlações da distância genética com a heterose dos híbridos e com a capacidade específica de combinação foram positivas, porém, pequenas $(r \leq 0,50)$ quando combinadas para todos os cruzamentos. Os resultados indicaram que RFLP pode ser usado para determinar a relação da genealogia entre as linhagens, mas também sugerem que as distâncias genéticas baseadas em RFLP são limitadas para predizer o desempenho heterótico dos híbridos simples entre linhagens não relacionadas.

Melchinger et al. (1990b) avaliaram a diversidade genética utilizando-se marcadores RFLP e sua relação com heterose em dois conjuntos dialélicos a partir de linhagens de milho. A análise de agrupamento baseada em distâncias genéticas revelou que a associação entre as linhagens foi consistente com o esperado baseando-se na genealogia. As correlações das distâncias genéticas com o desempenho dos híbridos, com a capacidade específica de combinação e com a heterose para a produção e seus componentes, foram geralmente positivas, mas pequenas para serem de valor preditivo. Os resultados mostraram que RFLP pode ser usado para verificar a relação entre linhagens de milho, mas são limitados para predição do desempenho heterótico de híbridos simples entre linhagens não relacionadas. 
Godshalk et al. (1990) conduziram um estudo para verificar a relação entre genótipos utilizando-se RFLP e determinar padrões heteróticos de um grupo de linhagens de milho. Um total de 22 linhagens foram cruzadas com quatro testadores e destes, 47 híbridos simples foram avaliados para várias características agronômicas. Foi estimada a distância genética entre as linhagens e a análise de componentes principais facilitou a visualização da dispersão das linhagens. Os resultados deste estudo sugerem que a análise de RFLP pode ter valor na alocação de linhagens de milho a grupos heteróticos, porém, nenhuma relação entre distância genética baseada em RFLP e desempenho do híbrido foi aparente.

Smith et al. (1990) realizaram um estudo para verificar se os marcadores RFLP's são úteis para estimar as similaridades genéticas entre linhagens, comparar as similaridades genéticas baseadas em marcadores moleculares com as relações de genealogia e verificar a associação entre diversidade genética baseada em RFLP com produção de grãos dos híbridos simples (HS) e heterose na produção de grãos. As distâncias genéticas foram calculadas entre 37 linhagens do cinturão do milho nos Estados Unidos. As distâncias genéticas baseadas em RFLP foram altamente correlacionadas com o coeficiente de parentesco entre os pares de linhagens. As distâncias baseadas em RFLP tinham uma correlação mais alta com performance de produção do HS e heterose na produção de grãos, que qualquer outra medida de similaridade destas mesmas linhagens. A análise de agrupamento baseada nos dados de RFLP agruparam as linhagens em famílias consistentes com o histórico do melhoramento e resposta heterótica dessas linhagens. Os autores concluíram que medidas de similaridades calculadas a partir de dados de RFLP, ligadas ao conhecimento da genealogia das linhagens, permitiram aos melhoristas prever combinações de linhagens que resultassem em alta produção.

Melchinger et al. (1991) avaliaram a utilidade dos marcadores RFLP para determinar padrões heteróticos e verificar a similaridade genética entre linhagens relacionadas e não relacionadas. Foram analisadas 32 linhagens de milho através de RFLP, sendo que nove destas linhagens eram da população lowa Stiff Stalk Synthetic 
(BSSS), oito eram da variedade Lancaster Sure Crop (LSC), quatro do grupo heterótico Reid Yellow Dent (RYD) e onze linhagens tinham origens variadas. As distâncias genéticas entre as linhagens revelaram considerável diversidade entre linhagens do BSSS, RYD e LSC. As linhagens de diferentes grupos heteróticos tinham uma distância genética média maior do que linhagens não relacionadas do mesmo grupo heterótico. As distâncias genéticas entre linhagens relacionadas concordaram com o esperado baseando-se no coeficiente de parentesco determinado com os dados da genealogia. A análise de componentes principais dos dados de RFLP resultou em um grupo com as linhagens de BSSS e RYD e outro grupo com linhagens de LSC. Os resultados deste estudo sugerem que RFLP pode ser usado para designar linhagens a grupos heteróticos e quantificar a similaridade genética entre as linhagens relacionadas.

Dudley et al. (1991) avaliaram 14 linhagens de milho em cruzamentos dialélicos e utilizaram dados de marcadores moleculares (aloenzimas e RFLP) com o objetivo de predizer o potencial de produção dos híbridos e designar linhagens a grupos heteróticos. A correlação da distância genética com produção do híbrido foi não significativa. $O$ agrupamento das linhagens baseado em distância genética concordou com a informação da genealogia, mas não concordou totalmente com o agrupamento baseado na produção, mostrando que deve-se ter cautela ao se designar linhagens a grupos heteróticos baseando-se somente na informação de marcadores.

Boppenmaier et al. (1992) realizaram um estudo para verificar a divergência genética das linhagens do grupo heterótico de milho duro e dentado da Europa e verificar a associação da distância genética baseada em RFLP com o desempenho de seus híbridos simples para características de forragem. As distâncias genéticas (DG's) entre as linhagens tinham maior média para as combinações das linhagens duro $\mathrm{x}$ dentado $(0,65)$ do que para duro $x$ duro $(0,58)$ ou dentado $x$ dentado $(0,59)$. A análise de agrupamento baseada nas DG's revelaram a associação entre as linhagens consistente com sua origem e sua genealogia. As distâncias genéticas não se correlacionaram significativamente $(|r| \leq 0,25)$ com desempenho do $F_{1}$ ou heterose para qualquer característica. Os resultados desse estudo confirmaram as informações prévias do germoplasma de milho 
nos Estados Unidos em que os dados de RFLP podem ser usados para designar linhagens a grupos heteróticos. Entretanto, distâncias baseadas em RFLP não são indicativas do desempenho dos híbridos simples entre linhagens de diferentes grupos heteróticos para características de forragem.

Melchinger et al. (1992) avaliaram a divergência genética baseada em RFLP em seis linhagens de milho duro e seis de milho dentado da Europa e o desempenho dos híbridos tanto entre como dentro dos grupos heteróticos. As distâncias genéticas foram maiores para as combinações duro $\mathrm{x}$ dentado do que para duro $\mathrm{x}$ duro e dentado $\mathrm{x}$ dentado. A análise de agrupamento baseada em distância genética resultou em grupos separados de linhagens de milho duro e dentado e estava de acordo com os dados da genealogia. As correlações genéticas para os 66 cruzamentos dialélicos da distância genética com desempenho do $F_{1}$, heterose e capacidade específica de combinação para algumas características de forragem foram moderadas $(0,09 \leq \mathrm{r} \leq 0,60)$. Os resultados indicaram que RFLP pode ser usado para designar linhagens a grupos heteróticos. Indicaram também, que as distâncias genéticas não são indicativos da produção do híbrido a partir de cruzamentos entre linhagens não relacionadas dos grupos heteróticos geneticamente divergentes.

Dhillon et al. (1993) avaliaram a relação da distância genética (DG) entre seis linhagens de milho duro (F) e seis dentadas (D) estimadas por RFLP com a produção de seus híbridos. Foram avaliados 36 híbridos FxD, 14 FxF e 12 DxD. As correlações de DG com o desempenho do híbrido $F_{1}$ e com a heterose foram significativas quando se considerou todos os 62 híbridos e para os 14 híbridos FxF, mas não para os 36 híbridos FxD. O estudo indicou que a divergência genética baseada em RFLP pode ser empregada para selecionar parentais para alta heterose e desempenho do híbrido $F_{1}$ em um programa de melhoramento, quando os híbridos intragrupos e intergrupos são considerados juntos. Entretanto, os resultados não dão suporte para o uso das medidas de distância genética baseadas em RFLP para predizer o desempenho dos híbridos intergrupos. 
Burstin et al. (1995) compararam o poder preditivo de diferentes distâncias genéticas derivadas de marcadores moleculares e da variação quantitativa das proteínas em um dialelo de 210 híbridos derivados de 21 linhagens de milho. As correlações entre distâncias genéticas e desempenho dos híbridos (desempenho na $F_{1}$ ou capacidade específica de combinação) foram de moderadas a altas nos dialelos entre as linhagens relacionadas. As distâncias genéticas baseadas na quantidade de proteínas mostraram, na maioria dos casos, similares ou baixas correlações. Os resultados indicaram que as medidas de distância não foram úteis como preditores do desempenho dos híbridos entre linhagens não relacionadas.

Outra classe de marcador genético utilizado é o RAPD, cuja simplicidade da técnica é a principal vantagem sobre RFLP (Welsh \& Mac Celland, 1990). Hahn et al. (1995) avaliaram a divergência genética de 51 linhagens de milho pertencentes aos grupos heteróticos de milho duro e dentado da Europa utilizando-se marcadores RAPD e também, comparam as similaridades genéticas baseadas em RAPD (SG) com o coeficiente de parentesco (f) baseado em dados de genealogia e com a similaridade genética baseada em dados de RFLP (SG*). Os resultados mostraram que as similaridades genéticas das linhagens do mesmo grupo heterótico foram maiores do que as similaridades entre as linhagens de grupos heteróticos opostos. A análise de coordenadas principais das SG's estimadas resultou na separação dos grupos de milho duro e dentado. As correlações entre SG com fe $\mathrm{SG}^{*}$ foram moderadas.

Com o objetivo de avaliar a diversidade genética de 18 linhagens de milho ( $8 \mathrm{da}$ população BR-105 e 10 da BR-106) e determinar a correlação entre distância genética e desempenho do híbrido simples, Lanza et al. (1997) utilizaram marcadores do tipo RAPD. A análise de agrupamento dividiu as amostras em três grupos distintos (GI, GII e GIII) que foram confirmados pelas análises de coordenadas principais. A distância genética correlacionou-se positivamente com a produção dos híbridos simples e com a heterose. Os autores relataram que nenhuma correlação foi encontrada quando a divisão dos grupos não foi considerada, mas correlações significativas foram detectadas entre as distâncias genéticas dos GI x GII e GI x GIII com os respectivos valores de produção de 
grãos dos híbridos simples. Observou-se que a população BR-106 foi dividida em dois grupos diferentes e a população BR-105 permaneceu como um único grupo. Os resultados indicaram que RAPD pode ser usado como uma ferramenta para a determinação da existência de divergência genética entre linhagens de milho tropical, para alocação dos genótipos dentro de diferentes grupos, bem como contribuir na escolha de cruzamentos superiores a serem feitos com linhagens de milho, reduzindo assim, o número de cruzamentos requeridos sob avaliações de campo.

Mais recentemente, uma nova classe de marcador genético chamada AFLP foi desenvolvida por Vos et al. (1995). AFLP's são marcadores mendelianos que fornecem uma ferramenta nova muito poderosa para analisar o DNA de genomas de qualquer origem e complexidade, incluindo os de milho. Anjmone Marsan et al. (1998) realizaram um estudo para comparar o uso de marcadores RFLP e AFLP e também, determinar a divergência genética de 13 linhagens de milho, assim como verificar a relação entre distância genética e desempenho do híbrido em cruzamentos dialélicos entre eles. Os autores relataram que uma variação considerável entre as linhagens foi detectada com os marcadores de RFLP e AFLP. No entanto, AFLP's foram mais eficientes em detectar polimorfismos em comparação com RFLP's, devido ao maior número de locos detectados em uma única reação de PCR (reação de polimerase em cadeia). As distâncias genéticas calculadas de dados de RFLP e AFLP foram maiores entre linhagens de diferentes grupos heteróticos, comparadas com as linhagens do mesmo grupo heterótico. As análises de agrupamento baseadas nas distâncias genéticas, revelaram associações entre as linhagens as quais concordam com o esperado baseado em dados de genealogia. Os valores das distâncias genéticas dos 78 híbridos simples foram divididos em componentes geral (DGG) e específicos (DGE). As correlações entre distância genética com desempenho dos híbridos simples para produção de grãos foram positivas, mas pequenas. Os autores concluíram que as correlações das DGE's, particularmente aquelas baseadas em dados de AFLP, com efeitos da capacidade específica de combinação para produção de grãos podem ter uma utilidade prática na predição de híbridos. 
A tendência geral do melhoramento genético de plantas é a integração das técnicas clássicas com aquelas mais modernas da biotecnologia, levando-se em consideração as vantagens e limitações de cada uma delas. Neste contexto, a tecnologia de marcadores moleculares pode contribuir significativamente na identificação de genótipos e designá-los aos seus respectivos grupos heteróticos. 


\section{MATERIAL E MÉTODOS}

\subsection{Caracterização das populações}

Para a realização do presente trabalho foram utilizadas as populações de milho BR-105 e BR-106. Essas populações foram desenvolvidas pelo Centro Nacional de Milho e Sorgo (Embrapa Milho e Sorgo) e ambas apresentam ciclo precoce e baixa altura da planta. A população BR-105 possui grãos alaranjados duros e baixa depressão por endogamia. Originalmente foi denominada de Suwan, tendo sido obtida na Tailândia e derivada de um programa de seleção recorrente com progênies $S_{1}$ com alta intensidade de seleção. A população BR-106 possui grãos amarelos dentados e foi obtida pelo intercruzamento das variedades tardias e de porte alto, formando um composto: Centralmex, Composto Dentado e Maya. Posteriormente esse composto foi intercruzado com a população BR-108 (Tuxpeño 1), de ciclo precoce e porte baixo. Após duas gerações de recombinação, seguiram-se três ciclos de seleção para redução da altura da planta e espiga. A população BR-106 apresenta maior variabilidade genética que a BR105 e em cruzamentos com a BR-105 apresenta heterose de magnitude elevada. Portanto, essas populações estão localizadas em grupos heteróticos distintos (Naspolini $F^{o}$ et al., 1981; Souza Jr. et al., 1993). 


\subsection{Obtenção do material genético}

$\mathrm{O}$ material genético desse trabalho foi constituído por oito e dez linhagens $\mathrm{S}_{3}$ das populações BR-105 e BR-106, respectivamente. Essas linhagens foram obtidas a partir de 400 linhagens $S_{3}$ de cada população que foram avaliadas em cruzamentos com a população recíproca, isto é, linhagens da população BR-105 x populaçãoBR-106, e viceversa. De cada população foram selecionadas 40 linhagens, as quais foram avaliadas e selecionadas pelas suas performances per se e uniformidade. No ano agrícola de 1991/92, no campo experimental da ESALQ/USP, município de Piracicaba/SP, as oito linhagens da população BR-105 e as dez da BR-106 foram cruzadas em um sistema dialélico produzindo 80 híbridos simples interpopulacionais. Foram realizados também cruzamentos dialélicos intrapopulacionais, os quais resultaram em 28 e 45 híbridos simples das populações BR-105 e BR-106, respectivamente. A genealogia e origem das linhagens utilizadas nesse trabalho encontram-se na Tabela 1.

Tabela 1. Genealogia e origem das 18 linhagens utilizadas no presente trabalho.

\begin{tabular}{ccc}
\hline Código de Uso & Genealogia & Origem \\
\hline 01 & $05-01.4 \mathrm{~B}$ & BR-105 \\
02 & $05-05.2 \mathrm{~A}$ & BR-105 \\
03 & $05-17.1 \mathrm{~A}$ & BR-105 \\
04 & $05-18.6 \mathrm{~A}$ & BR-105 \\
05 & $05-19.1 \mathrm{~B}$ & BR-105 \\
06 & $05-23.2 \mathrm{~B}$ & BR-105 \\
07 & $05-33.5 \mathrm{~B}$ & BR-105 \\
08 & $05-34.2 \mathrm{~B}$ & BR-105 \\
09 & $06-03.5 \mathrm{~B}$ & BR-106 \\
10 & $06-06.3 \mathrm{~A}$ & BR-106 \\
11 & $06-08.1 \mathrm{~A}$ & BR-106 \\
12 & $06-08.2 \mathrm{~A}$ & BR-106 \\
13 & $06-14.4 \mathrm{~B}$ & BR-106 \\
14 & $06-24.7 \mathrm{~B}$ & BR-106 \\
15 & $06-28.1 \mathrm{~A}$ & BR-106 \\
16 & $06-29.7 \mathrm{~B}$ & BR-106 \\
17 & $06-37.5 \mathrm{~B}$ & BR-106 \\
18 & $06-44.1 \mathrm{~B}$ & BR-106 \\
\hline
\end{tabular}




\subsection{Execução experimental}

Os 80 híbridos simples interpopulacionais foram avaliados em experimentos utilizando-se o delineamento experimental látice 10x10, aos quais foram adicionados 20 híbridos comerciais, perfazendo um total de 100 tratamentos. Os 28 e 45 híbridos simples intrapopulacionais foram avaliados conjuntamente em experimentos em látice 9x9, aos quais foram adicionados oito híbridos comerciais, resultando em 81 tratamentos. Os experimentos contendo os híbridos interpopulacionais foram avaliados no ano agrícola de 1992/93, sendo instalados em três locais da região de Piracicaba/SP: área experimental do Depto. de Genética da ESALQ/USP, Fazenda Areão e Fazenda Caterpillar, com duas repetições por local. Cada experimento foi semeado em duas épocas, sendo que, na análise de variância, cada época também foi considerada como um local. Os experimentos com os híbridos intrapopulacionais foram avaliados nos anos agrícolas de 1992/93 na Fazenda Caterpillar e de 1993/94 em dois locais (Fazenda Areão e Fazenda Caterpillar), com três repetições por local.

Nesses experimentos as parcelas foram constituídas por linhas de $4 \mathrm{~m}$ de comprimento, utilizando-se o espaçamento de $0,90 \mathrm{~m}$ entre linhas e $0,20 \mathrm{~m}$ entre plantas, sendo a área efetiva de $3,60 \mathrm{~m}^{2}$. Na semeadura foram colocadas 40 sementes por parcela e 15 dias após a germinação foi efetuado o desbaste, procurando-se manter o estande ideal de 20 plantas por parcela, resultando em uma densidade de aproximadamente 55.000 plantas/ha. As adubações de plantio e cobertura, além do controle de plantas daninhas, foram realizados de acordo com o recomendado para a cultura.

\subsection{Caracteres avaliados}

Os caracteres avaliados foram:

- Produção de grãos (PG): as espigas de cada parcela foram colhidas e encaminhadas ao galpão aonde permaneceram em local seco até a uniformização da umidade. Posteriormente, as espigas foram 
debulhadas, obtendo-se o peso dos grãos em quilogramas por parcela $(\mathrm{kg} /$ parcela), sendo esse transformado em toneladas por hectare ( $\mathrm{t} / \mathrm{ha})$;

- Altura da planta (AP): média da altura de cinco plantas competitivas amostradas aleatoriamente em cada parcela, medidas do nível do solo à inserção da folha bandeira (cm/planta);

- Altura da espiga (AE): média da altura das espigas das mesmas cinco plantas competitivas, medidas do nível do solo à inserção da primeira espiga ( $\mathrm{cm} /$ planta);

- Número de Espigas (NE): número de espigas por parcela no momento da colheita;

- Estande (ST): número de plantas por parcela;

- Posição relativa da espiga (PRE): corresponde ao quociente, em cada parcela, entre a altura média da espiga e a altura média da planta (AE/AP);

- Prolificidade (PROL): é obtido através do quociente entre o número de espigas por parcela e o número de plantas por parcela (espigas/planta).

Nos experimentos com os híbridos intrapopulacionais, os caracteres número de espigas, estande e prolificidade, foram avaliados nos três ambientes, sendo os demais caracteres avaliados em apenas dois ambientes.

\subsection{Obtenção dos dados de RFLP}

Os dados referentes aos marcadores moleculares foram obtidos no Centro de Biologia Molecular e Engenharia Genética da Universidade Estadual de Campinas (UNICAMP) sob coordenação da professora Anete Pereira de Souza, sendo os dados gentilmente cedidos para a realização do presente trabalho. 
O DNA genômico foi isolado de um conjunto de tecidos foliares de 16 plantas de cada linhagem com cinco semanas de idade. O material foi liofilizado, moído e o DNA genômico foi extraído usando o método CTAB. O DNA foi purificado por extração com fenol e depois foi separadamente cortado com quatro diferentes enzimas de restrição (Eco RI, Eco RV, Hind III e Bam HI). A extração de DNA, a eletroforese em gel de agarose, a transferência "Southern" para membranas de nylon, a hibridização com sondas Dioxigenin-dutp e a exposição das membranas foram feitas como descrito por Hoisington et al. (1994).

Oitenta e oito sondas de DNA foram utilizadas para hibridação, fornecendo uma cobertura uniforme do genoma do milho. Os padrões de RFLP foram visualmente analisados nas autorradiografias para cada combinação sonda-enzima. Cada combinação foi considerada como um loco e os dados foram registrados somente para aquelas combinações que apresentaram uma boa intensidade de banda. Os dados foram tomados de acordo com a presença ou ausência ( 1 ou 0 , respectivamente) de cada banda em cada linhagem.

\subsection{Análises estatístico-genéticas}

\subsubsection{Análises de variâncias}

Foram feitas as análises individuais dos experimentos em látice para cada ambiente segundo o procedimento de Cochran \& Cox (1957) e, a seguir, as análises de variâncias conjuntas envolvendo todos os ambientes. As análises conjuntas foram realizadas utilizando-se os valores das médias ajustadas dos cruzamentos. Para o caráter produção de grãos (PG) foram feitas correções do estande com base no estande médio através do método da covariância (Vencovsky \& Barriga, 1992), onde um grau de liberdade do resíduo é subtraído em função dessas correções. 
Para cada um dos caracteres, em um ambiente, o modelo matemático utilizado foi:

$$
Y_{i j k}=\mu+t_{i}+r_{j}+b_{k(j)}+e_{i j k}
$$

em que:

$Y_{\mathrm{ijk}}$ : efeito do tratamento i, no bloco $\mathrm{k}$, da repetição j;

$\mu$ : média geral do experimento;

$t_{i}$ : efeito fixo do tratamento $i$, em que $i=1,2, \ldots, I ; E\left(t_{i}\right)=t_{i} e E\left(t_{i}^{2}\right)=\varnothing t$;

$\mathrm{r}_{\mathrm{j}}$ : efeito aleatório da repetição $\mathrm{j}$, em que $\mathrm{j}=1,2, \ldots, \mathrm{J}$;

$b_{k(j)}$ : efeito aleatório do bloco $k$, na repetição $j$, em que $k=1,2, \ldots, \mathrm{K}$;

$\mathrm{e}_{\mathrm{ijk}}$ : erro intrabloco, ou seja, erro experimental associado ao tratamento $\mathrm{i}$, dentro do bloco $\mathrm{k}$ na repetição $\mathrm{j} ; \mathrm{E}\left(\mathrm{e}_{\mathrm{ijk}}\right)=0$ e $\mathrm{E}\left(\mathrm{e}_{\mathrm{ijk}}{ }^{2}\right)=\sigma_{e}^{2}$.

Para as análises de variâncias conjuntas foi adotado o seguinte modelo matemático:

$$
Y_{i j l}=\mu+t_{i}+r_{j(l)}+a_{1}+(t a)_{i l}+e_{i j l}
$$

em que:

$Y_{\mathrm{ijl}}$ : efeito do tratamento $\mathrm{i}$, na repetição $\mathrm{j}$, do ambiente $\mathrm{l}$;

$\mu$ : média geral do experimento;

$t_{i}$ : efeito fixo do tratamento $i$, em que $i=1,2, \ldots, I ; E\left(t_{i}\right)=t_{i} \in E\left(t_{i}{ }^{2}\right)=\varnothing t$;

$\mathrm{r}_{\mathrm{j}(1)}$ : efeito da repetição $\mathrm{j}$ dentro do ambiente $\mathrm{l}$;

a!: efeito aleatório do ambiente 1 , em que $1=1,2, \ldots, \mathrm{L}$;

$(\mathrm{ta})_{\mathrm{il}}$ : efeito da interação entre o tratamento i e o ambiente $\mathrm{l} ; \mathrm{E}\left(\mathrm{ta}_{\mathrm{il}}\right)=0$ e $\mathrm{E}\left(\mathrm{ta}_{\mathrm{il}}{ }^{2}\right)=\sigma_{\mathrm{ta}}^{2}$;

$\mathrm{e}_{\mathrm{ijl} 1}$ erro efetivo médio associado à parcela ij do ambiente $1 ; \mathrm{E}\left(\mathrm{e}_{\mathrm{ijl}}\right)=0$ e $\mathrm{E}\left(\mathrm{e}_{\mathrm{ijl}}{ }^{2}\right)=\sigma_{e}^{2}$.

Os esquemas das análises de variâncias individual e conjunta com as respectivas esperanças matemáticas dos quadrados médios para todos os caracteres encontram-se nas Tabelas 2 e 3 . 
Tabela 2. Esquema da análise de variância segundo o delineamento em látice com as esperanças matemáticas dos quadrados médios $\mathrm{E}(\mathrm{QM})$ e teste $\mathrm{F}$.

\begin{tabular}{llccc}
\hline F.V. & G.L. & Q.M. & $\mathrm{E}(\mathrm{QM})^{+}$ & $\mathrm{F}$ \\
\hline Repetições & $(\mathrm{J}-1)$ & $\mathrm{Q}_{1}$ & & - \\
Blocos (aj.) & $\mathrm{J}(\mathrm{K}-1)$ & $\mathrm{Q}_{2}$ & - & - \\
Tratamentos (aj.) & $\mathrm{I}-1$ & $\mathrm{Q}_{3}$ & $\sigma_{e}^{2}+\mathrm{J} \varnothing \mathrm{t}$ & $\mathrm{Q}_{3} / \mathrm{Q}_{4}$ \\
Erro intrabloco & $(\mathrm{JK}-\mathrm{K}-1)(\mathrm{K}-1)$ & $\mathrm{Q}_{4}$ & $\sigma_{e}^{2}$ & \\
\hline${ }^{+} \varnothing \mathrm{t}: \frac{1}{\mathrm{I}-1} \sum_{\mathrm{i}} \mathrm{t}_{\mathrm{i}}^{2}$ & & & & \\
\end{tabular}

Tabela 3. Esquema da análise de variância conjunta com as esperanças matemáticas dos quadrados médios $\mathrm{E}(\mathrm{QM})$ e teste $\mathrm{F}$.

\begin{tabular}{llccc}
\hline F.V. & G.L. & Q.M. & $\mathrm{E}(\mathrm{QM})$ & $\mathrm{F}$ \\
\hline Ambientes (A) & $\mathrm{L}-1$ & $\mathrm{Q}_{2}$ & - & - \\
Repetições/A & $\mathrm{L}(\mathrm{J}-1)$ & $\mathrm{Q}_{1}$ & - & - \\
Tratamentos (T) & $\mathrm{I}-1$ & $\mathrm{Q}_{3}$ & $\sigma_{e}^{2}+\mathrm{J} \sigma_{\mathrm{a}}^{2}+\mathrm{JK} \varnothing \mathrm{t}$ & $\mathrm{Q}_{3} / \mathrm{Q}_{4}$ \\
T x A & $(\mathrm{I}-1)(\mathrm{L}-1)$ & $\mathrm{Q}_{4}$ & $\sigma_{e}^{2}+\mathrm{J} \sigma_{\mathrm{t}}^{2}$ & $\mathrm{Q}_{4} / \mathrm{Q}_{5}$ \\
Erro efetivo médio & $\mathrm{L}(\mathrm{K}-1)(\mathrm{JK}-\mathrm{K}-1)$ & $\mathrm{Q}_{5}$ & $\sigma_{e}^{2}$ & \\
\hline
\end{tabular}

\subsubsection{Análise dialélica}

As análises de capacidade combinatória foram efetuadas de acordo com o método 4, modelo I de Griffing (1956), onde somente os híbridos $F_{1}$ 's são avaliados. Esse modelo supõe que o efeito de tratamentos é fixo, pois foram utilizadas 8 linhagens da população BR-105 e 10 linhagens da BR-106. Essas análises envolveram as médias dos 80 híbridos simples interpopulacionais, e dos 28 e 45 híbridos simples intrapopulacionais das populações BR-105 e BR-106, respectivamente. 
O modelo estatístico considerado para a análise de capacidade de combinação, procedida com base na média das repetições dos híbridos intrapopulacionais, foi o seguinte:

$$
Y_{i j k}=\mu+l_{k}+g_{i}+g_{j}+s_{i j}+(l g)_{i k}+(l g)_{j k}+(l s)_{i j k}+\bar{\varepsilon}_{i j k}
$$

com as seguintes restrições:

$\sum_{k} \mathrm{l}_{\mathrm{k}}=\sum_{i} \mathrm{~g}_{i}=\sum_{j} \mathrm{~g}_{j}=\sum_{j} s_{i j}=\sum_{k} \lg _{i k}=\sum_{k} \lg _{j k}=\sum_{k} \mathrm{ls}_{i j k}=0$

em que:

$Y_{\mathrm{ijk}}$ : valor médio da combinação híbrida da i-ésima e j-ésima linhagens (i, j = 1, 2, .., $\mathrm{p}$, $\mathrm{i}<$ j) no i-ésimo ambiente;

$\mu$ : média do híbrido considerando-se todos os ambientes;

$\mathrm{l}_{\mathrm{k}}$ : é o efeito do k-ésimo ambiente;

$\mathrm{g}_{\mathrm{i}}, \mathrm{g}_{\mathrm{j}}$ : efeitos das capacidades gerais de combinação da i-ésima e j-ésima linhagens, respectivamente;

$\mathrm{s}_{\mathrm{ij}}$ : efeito da capacidade específica de combinação para os cruzamentos entre as linhagens de ordem i e $\mathrm{j}$, sendo $s_{\mathrm{ij}}=\mathrm{s}_{\mathrm{ji}}$;

$\lg _{\mathrm{ik}}, \lg _{\mathrm{jk}}$ : interação entre ambientes e os efeitos da capacidade geral de combinação;

$1 s_{\mathrm{ijk}}$ : interação entre ambientes e os efeitos da capacidade específica de combinação entre a i-ésima e j-ésima linhagens;

$\bar{\varepsilon}_{\mathrm{ijk}}$ : erro experimental médio.

Como o dialelo referente às combinações híbridas das linhagens da população BR-106 não continha todas as combinações híbridas, foi utilizado o método dos quadrados mínimos (Vencovsky \& Barriga, 1992).

As estimativas dos efeitos da CGC e da CEC, para cada caráter avaliado, foram obtidas pelas seguintes expressões:

$\begin{aligned} \hat{\mu} & =\frac{2 Y_{\ldots}}{k p(p-1)} ; \\ \hat{\mathrm{g}}_{i} & =\frac{p Y_{i . .}-2 Y_{\ldots} \ldots}{k p(p-2)}\end{aligned}$ 
$\hat{\mathrm{s}}_{i j}=\frac{\underline{i j}}{k}-\frac{(p-1)\left(Y_{i . .}+Y_{. j}\right)-2 Y \ldots}{k(p-1)(p-2)}$.

As variâncias dos efeitos e dos contrastes entre os efeitos foram estimados por:

$\operatorname{Var}(\hat{\mu})=\frac{2}{\operatorname{kp}(p-1)} \sigma_{e}^{2}, \operatorname{Var}\left(\hat{\mathrm{g}}_{\mathrm{i}}\right)=\frac{(p-1)}{\mathrm{kp}(p-2)} \sigma_{e}^{2}, \operatorname{Var}\left(\hat{\mathrm{S}}_{\mathrm{ij}}\right)=\frac{p-3}{\mathrm{k}(\mathrm{p}-1)} \sigma_{e}^{2}$

$\operatorname{Var}\left(\hat{\mathrm{g}}_{\mathrm{i}}-\hat{\mathrm{s}}_{\mathrm{j}}\right)=\frac{2}{\mathrm{k}(\mathrm{p}-2)} \sigma_{e}^{2}, \operatorname{Var}\left(\hat{\mathrm{s}}_{\mathrm{ij}}-\hat{\mathrm{s}}_{\mathrm{ik}}\right)=\frac{2(p-3)}{k(p-2)} \sigma_{e}^{2}, \operatorname{Var}\left(\hat{\mathrm{s}}_{\mathrm{ij}}-\hat{\mathrm{s}}_{\mathrm{m}}\right)=\frac{2(p-4)}{k(p-2)} \sigma_{e}^{2}$.

Para a análise da capacidade de combinação dos híbridos interpopulacionais foi adotado o seguinte modelo estatístico:

$$
Y_{i j k}=\mu+l_{k}+g_{i}+g_{j j}+s_{i j}+(l g)_{i k}+(\lg )_{j k}+(l s)_{i j k} \bar{\varepsilon}_{i j k}
$$

com as seguintes restrições:

$\sum_{k} \mathrm{l}_{\mathrm{k}}=\sum_{i} \mathrm{~g}_{i}=\sum_{\mathrm{j}} \mathrm{g}_{\mathrm{j}}^{\prime}=\sum_{\mathrm{j}} \mathrm{s}_{\mathrm{ij}}=\sum_{k} \lg _{i k}=\sum_{k} \lg _{j k}=\sum_{k} \mathrm{ls}_{\mathrm{ijk}}=0$

em que:

$Y_{\mathrm{ijk}}$ : valor médio da combinação híbrida entre a i-ésima linhagem do grupo 1 (BR-106) e a j-ésima linhagem do grupo 2 (BR-105) no k-ésimo ambiente;

$\mu$ : média do híbrido considerando-se todos os ambientes;

$l_{k}$ : efeito do k-ésimo ambiente;

$\mathrm{g}_{i}$ : efeito da capacidade geral de combinação da i-ésima linhagem do grupo 1;

$\mathrm{g}_{\mathrm{j}}$ : efeito da capacidade geral de combinação da j-ésima linhagem do grupo 2;

$\mathrm{s}_{\mathrm{ij}}$ : efeito da capacidade específica de combinação entre linhagens i e j, dos grupos 1 e 2 , respectivamente;

$\lg _{\mathrm{ik}}, \lg _{\mathrm{j} k}$ : interação entre ambientes e os efeitos da capacidade geral de combinação;

$1 s_{\mathrm{ijk}}$ : interação entre ambientes e os efeitos da capacidade específica de combinação entre a i-ésima linhagem do grupo 1 e j-ésima linhagem do grupo 2;

$\bar{\varepsilon}_{\mathrm{ijk}}$ : erro experimental médio.

As estimativas para os efeitos da CGC e da CEC, para cada caráter avaliado, foram obtidas pelas seguintes expressões:

$\hat{\mu}=\frac{Y}{k p q} \cdot$ 


$$
\begin{aligned}
& \hat{\mathrm{g}}_{i}=\frac{Y_{i . .}}{k q}-\frac{Y_{\ldots}}{k p q} ; \\
& \hat{\mathrm{g}}_{\mathrm{j}}^{\prime}=\frac{Y_{. j .}}{k p}-\frac{Y_{\ldots . .}}{k p q} ; \\
& \hat{\mathrm{s}}_{\mathrm{ij}}=\frac{Y_{i j .}}{k}-\frac{Y_{i . .}}{k q}-\frac{Y_{. j .}}{k p}+\frac{Y_{\ldots}}{k p q} .
\end{aligned}
$$

As variâncias dos efeitos e dos contrastes entre os efeitos foram estimados por:

$\operatorname{Var}(\hat{\mu})=\frac{1}{\mathrm{kpq}} \sigma_{e}^{2}, \operatorname{Var}\left(\hat{\mathrm{g}}_{i}\right)=\frac{(p-1)}{\mathrm{kpq}} \sigma_{e}^{2}, \operatorname{Var}\left(\hat{\mathrm{g}}_{\mathrm{j}}^{\prime}\right)=\frac{(q-1)}{\mathrm{kpq}} \sigma_{e}^{2}, \operatorname{Var}\left(\hat{\mathrm{s}}_{\mathrm{ij}}\right)=\frac{(p-1)(q-1)}{\mathrm{kp} q} \sigma_{e}^{2} ;$

$\operatorname{Var}\left(\hat{\mathrm{g}}_{t}-\hat{\mathrm{g}}_{\mathrm{i}^{\prime}}\right)=\frac{2}{k q} \sigma_{e}^{2}, \operatorname{Var}\left(\hat{\mathrm{g}}_{j}^{\prime}-\hat{\mathrm{g}}_{\mathrm{j}^{\prime}}^{\prime}\right)=\frac{2}{k p} \sigma_{e}^{2}, \operatorname{Var}\left(\hat{\mathrm{s}}_{\mathrm{ij}}-\hat{\mathrm{S}}_{\mathrm{ik}}\right)=\frac{2(p-1)}{k p} \sigma_{e}^{2}$

$\operatorname{Var}\left(\hat{\mathrm{s}}_{\mathrm{ij}}-\hat{\mathrm{s}}_{\mathrm{kj}}\right)=\frac{2(q-1)}{k q} \sigma_{e}^{2}, \operatorname{Var}\left(\hat{\mathrm{s}}_{\mathrm{ij}}-\hat{\mathrm{s}}_{\mathrm{kl}}\right)=\frac{2(p q-p-q)}{k p q} \sigma_{e}^{2}$

Os esquemas das ANAVAS, para a capacidade geral de combinação (CGC) e a capacidade específica de combinação (CEC), pelo método 4, modelo fixo (I) de Griffing (1956), para os cruzamentos intra e interpopulacionais, estão nas Tabelas 4 e 5 , respectivamente.

Tabela 4. Esquema da análise de variância do dialelo intrapopulacional pelo método 4, modelo I de Griffing (1956).

\begin{tabular}{llll}
\hline F.V. & G.L. & Q.M. & \multicolumn{1}{c}{$\mathrm{F}$} \\
\hline Ambientes (A) & $(\mathrm{K}-1)$ & $\mathrm{QM}_{\mathrm{A}}$ & $\mathrm{QM}_{\mathrm{A}}$ \\
C.G.C. & $(\mathrm{p}-1)$ & $\mathrm{QM}_{\mathrm{G}}$ & $\mathrm{QM}_{\mathrm{G}} / \mathrm{QM}_{\mathrm{GxA}}$ \\
C.E.C. & {$[\mathrm{P}(\mathrm{p}-3) / 2]$} & $\mathrm{QM}_{\mathrm{S}}$ & $\mathrm{QM}_{\mathrm{S}} / \mathrm{QM}_{\mathrm{SxA}}$ \\
C.G.C. x A & $(\mathrm{K}-1)(\mathrm{p}-1)$ & $\mathrm{QM}_{\mathrm{GxA}}$ & $\mathrm{QM}_{\mathrm{G}} / \mathrm{QM}_{\mathrm{R}}$ \\
C.E.C. x A & $(\mathrm{K}-1)[\mathrm{P}(\mathrm{p}-3) / 2]$ & $\mathrm{QM}_{\mathrm{SxA}}$ & $\mathrm{QM}_{\mathrm{S}} / \mathrm{QM}_{\mathrm{R}}$ \\
Erro combinado & $\sum_{k} \mathrm{~g}_{\mathrm{k}}$ & $\mathrm{QM}_{\mathrm{R}}$ & - \\
\hline
\end{tabular}

$\mathrm{g}_{\mathrm{k}}$ : número de graus de liberdade do resíduo no k-ésimo ambiente.

p: número de linhagens.

As somas de quadrados das análises dos cruzamentos dialélicos intrapopulacionais foram obtidas segundo Ferreira et al. (1993). O quadrado médio do resíduo $\left(\mathrm{QM}_{\mathrm{R}}\right)$ foi obtido através soma dos quadrados médios das análises de variância 
individuais divididos pelo número de repetições e locais. Os demais quadrados médios foram obtidos na maneira usual.

Tabela 5. Esquema da análise de variância do dialelo interpopulacional pelo método 4, modelo I de Griffing (1956).

\begin{tabular}{llll}
\hline F.V. & G.L. & Q.M. & \multicolumn{1}{c}{$\mathrm{F}$} \\
\hline Ambientes (A) & $(\mathrm{k}-1)$ & $\mathrm{QM}_{\mathrm{A}}$ & $\mathrm{QM}_{\mathrm{A}} / \mathrm{QM}_{\mathrm{R}}$ \\
C.G.C. 1 (BR-106) & $(\mathrm{p}-1)$ & $\mathrm{QM}_{\mathrm{G} 1}$ & $\mathrm{QM}_{\mathrm{Gl}} / \mathrm{QM}_{\mathrm{G} 1 \times \mathrm{A}}$ \\
C.G.C. 2(BR-105) & $(\mathrm{q}-1)$ & $\mathrm{QM}_{\mathrm{G} 2}$ & $\mathrm{QM}_{\mathrm{G} 2} / \mathrm{QM}_{\mathrm{G} 2 \times \mathrm{A}}$ \\
C.E.C. & $(\mathrm{p}-1)(\mathrm{q}-1)$ & $\mathrm{QM}_{\mathrm{S}}$ & $\mathrm{QM}_{\mathrm{S}} / \mathrm{QM}_{\mathrm{SxA}}$ \\
C.G.C. 1 x A & $(\mathrm{k}-1)(\mathrm{p}-1)$ & $\mathrm{QM}_{\mathrm{G} 1 \times \mathrm{A}}$ & $\mathrm{QM}_{\mathrm{G} 1 \times \mathrm{A}} / \mathrm{QM}_{\mathrm{R}}$ \\
C.G.C. 2 x A & $(\mathrm{k}-1)(\mathrm{q}-1)$ & $\mathrm{QM}_{\mathrm{G} 2 \times \mathrm{A}}$ & $\mathrm{QM}_{\mathrm{G} 2 \times \mathrm{A}} / \mathrm{QM}_{\mathrm{R}}$ \\
C.E.C. x A & $(\mathrm{k}-1)(\mathrm{p}-1)(\mathrm{q}-1)$ & $\mathrm{QM}_{\mathrm{SxA}}$ & $\mathrm{QM}_{\mathrm{SxA}} / \mathrm{QM}_{\mathrm{R}}$ \\
Erro combinado & $\sum_{k} \mathrm{~g}_{\mathrm{k}}$ & $\mathrm{QM}_{\mathrm{R}}$ & - \\
\hline
\end{tabular}

p e q: número de linhagens das populações BR-106 e BR-105, respectivamente.

As somas de quadrados das análises dos cruzamentos dialélicos interpopulacionais foram obtidas segundo Vencovsky \& Barriga (1992).

$O$ teste $t$ foi utilizado para verificar se as estimativas dos efeitos da CGC e CEC diferem de zero e, também, a significância dos contrastes entre os efeitos, isto é (Vencovsky \& Barriga, 1992):

$t=\frac{\hat{Y}-0}{\sqrt{\hat{V}(\hat{Y})}}$ ou $t=\frac{\hat{Y}-\hat{Y}^{\prime}}{\sqrt{\hat{V}\left(\hat{Y}-\hat{Y}^{\prime}\right)}}$

em que:

$\hat{Y}$ : estimativa dos efeitos da CGC ou CEC;

$\sqrt{\hat{V}(\hat{Y})}:$ desvio padrão dos efeitos;

$\hat{Y}-\hat{Y}^{\prime}$ : estimativa do contraste entre os efeitos da CGC ou CEC;

$\sqrt{\hat{V}\left(\hat{Y}-\hat{Y}^{\prime}\right)}$ : desvio padrão dos contrastes. 
Esses valores foram comparados com os valores críticos de $t$, tabelados em função do número de graus de liberdade associados ao resíduo da análise de variância conjunta.

\subsubsection{Análise dos dados de marcadores}

Os coeficientes de similaridade genética (SG) entre todas as linhagens foram gerados a partir da matriz binária utilizando-se o índice de Jaccard de acordo com Sneath \& Sokal (1973):

$$
S G=\frac{N_{i j}}{N_{i}+N_{j}+N_{i j}}
$$

em que: $\mathrm{N}_{\mathrm{ij}}$ é o número total de bandas comuns as linhagens i e $\mathrm{j} ; \mathrm{N}_{\mathrm{i}}$ é o número de bandas presentes somente nas linhagens i e $\mathrm{N}_{\mathrm{j}}$ é o número de bandas presentes somente nas linhagens j. As distâncias genéticas (DG) entre pares de linhagens foram estimadas como $\mathrm{DG}=1-\mathrm{SG}$.

\subsubsection{Critérios para formar os grupos heteróticos}

Após a realização da análise dialélica, foi feita a determinação de padrões heteróticos das linhagens utilizando-se como medida de divergência genética os valores da capacidade específica de combinação. Esses valores foram considerados como medidas de divergência genética partindo-se do princípio de que se as linhagens não são divergentes estas devem expressar baixa capacidade específica de combinação em cruzamentos. Entretanto, quando as linhagens são divergentes, expressam alta capacidade específica de combinação em cruzamentos. 
Foram utilizados três critérios para a formação dos grupos heteróticos, isto é, as linhagens foram separadas em grupos heteróticos baseando-se no maior valor da estimativa de CEC e as duas linhagens que participaram desse cruzamento foram alocadas em grupos heteróticos distintos e, baseando-se nas estimativas de CEC das combinações dessas linhagens com as demais, os grupos heteróticos foram formados; as linhagens foram separadas também pelo método de agrupamento, onde o dendograma foi construído pelo método UPGMA (média aritmética não ponderada) a partir da matriz das estimativas das capacidades específicas de combinação; e a separação das linhagens também foi feita através da dispersão gráfica dos dados pelo método de ordenação de coordenadas principais (PCO, Manly, 1994),em que utilizou-se um sistema de três coordenadas principais. Essas análises foram obtidas utilizando-se o programa de análise estatística NTSYS (Numerical Taxonomy and Multivariate Analysis System), versão 2.0E (Rohlf, 1997).

A formação dos grupos a partir dos dados de marcadores moleculares foi realizada utilizando-se o método de agrupamento (UPGMA) a partir das distâncias genéticas e a dispersão gráfica dos dados foi realizada pelo método de ordenação de coordenadas principais. O método estatístico Bootstrap foi utilizado a partir da matriz de ausência e presença dos dados de RFLP para se determinar a precisão dos dendogramas gerados a partir das análises de agrupamento. O Bootstrap é um método de reamostragem dos próprios dados e é utilizado quando não se conhece a distribuição dos dados ou quando algum método de estimação estatística é muito complicado e o seu erro padrão é dificil de ser estimado (Felsenstein, 1985). Foram feitas 1.000 reamostragens dos próprios dados , com reposição, para criar uma série de amostras de tamanho igual a 18 , sendo que a cada reamostragem era formado um dendograma. No final, foi gerado um dendograma mostrando em porcentagem quantas vezes aqueles grupos permaneceram repetidos nas 1.000 reamostragens, ou seja, o valor de $95,0 \%$ para um grupo significa que em 950 vezes que as linhagens foram reamostradas, as linhagens daquele grupo permaneceram juntas. A inspeção visual desse dendograma permitiu verificar a consistência dos grupos formados. 
A determinação dos grupos heteróticos obtidos a partir de estimativas de CEC e RFLP foi feita após a inspeção visual dos dendogramas e dos gráficos em três e duas dimensões, em que as linhagens com menor distância foram alocadas no mesmo grupo heterótico.

Devido à presença de estimativas negativas das capacidades específicas de combinação, na realização das análises de agrupamento uma constante foi a elas adicionada. Essa constante apenas transformou os valores negativos em positivos, mas sem alterar a posição dessas estimativas. Esse artificio foi utilizado devido à restrições para as análises de coordenadas principais. A linhagem 16, pertencente à população BR106, foi excluída dos agrupamentos por causa de falhas na tabela dialélica.

\subsubsection{Estimativas de correlações}

Foram obtidas correlações de Spearman entre as estimativas da capacidade específica de combinação das linhagens dos diversos caracteres e as distâncias genéticas obtidas por RFLP. As correlações foram realizadas do seguinte modo (Steel \& Torrie, 1980):

a) Obtenção da posição (rank) de cada observação;

b) Obtenção das diferenças nos ranks das observações;

c) Estimativa da correlação utilizando-se a seguinte fórmula:

$$
r_{s}=1-\frac{6 \sum_{i} d_{i}^{2}}{(n-1) n(n+1)}
$$

em que, d é a diferença nos ranks das observações e $\mathrm{n}$ é o número de observações. 


\section{RESULTADOS E DISCUSSÃO}

\subsection{Análise de variância}

Os valores e respectivas significâncias dos quadrados médios e os coeficientes de variação das análises de variâncias para os híbridos intrapopulacionais e os interpopulacionais apresentam-se nas Tabelas 6 e 7, respectivamente.

Os quadrados médios para tratamentos foram significativos $(\mathrm{P} \leq 0,01)$, pelo teste F, para todos os caracteres avaliados, tanto nos híbridos intrapopulacionais quanto nos interpopulacionais. Apenas o caráter prolificidade, nos híbridos intrapopulacionais, foi não significativo, indicando que a variabilidade para esse caráter foi baixa. Esses resultados evidenciam a existência de variação genética entre as linhagens, pois os híbridos se comportaram de forma diferenciada. A existência dessa variação é importante porque indica que determinadas combinações entre as linhagens são superiores às demais. Isso mostra que as linhagens podem ser separadas em grupos heteróticos distintos.

A fonte de variação ambientes mostrou-se significativa para todos os caracteres, tanto nas análises intra como interpopulacionais, o que indica a diferença entre ambientes. A interação tratamentos $\mathrm{x}$ ambiente foi significativa tanto para os híbridos intrapopulacionais quanto para os interpopulacionais, indicando que os híbridos apresentaram comportamento diferencial nos diversos ambientes. 
Os coeficientes de variação obtidos foram de $10,0 \%, 4,0 \%, 6,3 \%, 3,5 \%$ e $18,4 \%$ para os caracteres produção de grãos (PG), altura da planta (AP), altura da espiga (AE), posição relativa da espiga (PRE) e prolificidade (PROL), respectivamente para os híbridos intrapopulacionais, e de $11,8 \%, 4,0 \%, 6,3 \%, 4,1 \%$ e $11,3 \%$ para PG, AP, AE, PRE e PROL, respectivamente, nos híbridos interpopulacionais, sendo considerados dentro dos limites aceitáveis na experimentação agrícola. Os valores dos coeficientes de variação das análises individuais (dados não mostrados) foram semelhantes aos da análise conjunta, indicando uma boa precisão na condução dos experimentos. As médias dos experimentos para os caracteres PG, AP, AE, PRE e PROL foram de 6,44 t/ha, $207,54 \mathrm{~cm} /$ planta, $107,82 \mathrm{~cm} /$ planta, 0,52 e 1,42 espigas/planta, respectivamente para os híbridos intrapopulacionais e de 7,37 t/ha, 205,94 cm/planta, 105,56 cm/planta, 0,51 e 0,98 espigas/planta, respectivamente para os híbridos interpopulacionais.

\subsection{Análises da capacidade de combinação}

As análises de variâncias dos cruzamentos dialélicos conforme o método IV de Griffing (1956), para as linhagens das populações BR-105 e BR-106 avaliadas em cruzamentos intrapopulacionais e para os cruzamentos interpopulacionais (BR-105 $\mathrm{x}$ BR-106) estão apresentados nas Tabelas 8, 9 e 10, respectivamente.

Os quadrados médios das capacidades gerais de combinação (CGC), relativos aos híbridos da população BR-105, foram significativos para todos os caracteres avaliados. Entretanto, os quadrados médios das capacidades específicas de combinação (CEC), foram significativos apenas para o caráter produção de grãos (Tabela 8). Resultado semelhante ocorreu para a população BR-106, em que os quadrados médios da CGC foram significativos para todos os caracteres, enquanto que para a CEC, somente o quadrado médio referente a produção de grãos foi significativo (Tabela 9). Para os híbridos interpopulacionais, os quadrados médios das CGC e CEC foram significativos para todos os caracteres avaliados (Tabela 10). A significância dos quadrados médios para ambas as capacidades combinatórias indicam a existência de variabilidade entre os 
efeitos da CGC, associados a efeitos gênicos aditivos, e entre os efeitos da CEC, associados a efeitos gênicos não aditivos.

A relativa contribuição das somas de quadrados das capacidades geral (CGC) e específica (CEC) de combinação em relação às somas de quadrados de tratamentos revelou para os caracteres PG, AP, AE, PRE e PROL, na população BR-105 que a CGC contribuiu com $68,3 \%, 75,4 \%, 80,2 \%, 78,1 \%$ e $58,5 \%$, respectivamente e na população BR-106 com 88,7\%, 76,9\%, 78,1\%, 74,1\% e 87,4\%, respectivamente. Nos cruzamentos interpopulacionais para os caracteres PG, AP, AE, PRE e PROL na população BR-106 a CGC contribuiu com $87,1 \%, 86,9 \%, 86,2 \%, 87,4 \%$ e $81,9 \%$, respectivamente e na população BR-105 foi de $81,7 \%, 94,9 \%, 92,6 \%, 90,2 \%$ e $75,8 \%$, respectivamente. Verifica-se que os valores da contribuição da CGC variaram de $58,5 \%$ a $94,9 \%$, caracterizando assim, a importância dos efeitos aditivos no controle desses caracteres. Portanto, a variação entre os cruzamentos foi devido principalmente a efeitos aditivos do que não aditivos. Resultados mostrando que os efeitos aditivos são mais importantes que os efeitos não aditivos (dominância e epistasia) foram relatados por diversos autores para vários caracteres em milho (Naspolini $\mathrm{F}^{0}$ et al., 1981; Mungoma \& Pollak, 1988; Vasal et al., 1992a,b, 1993b; Ferreira et al., 1995; Gama et al., 1995; Spaner et al., 1996).

Os quadrados médios das interações da CGC e CEC com ambientes, relativos às linhagens das populações BR-105 e BR-106 avaliadas à nível intrapopulacional, foram não significativos para todos os caracteres avaliados e em ambas as populações, com exceção apenas do caráter PG na população BR-105. Nos híbridos interpopulacionais, os quadrados médios das interações da CGC1 e CGC2 com ambientes foram significativos para todos os caracteres e o quadrado médio da interação da CEC com ambientes foi significativo apenas para o caráter PG.

\subsubsection{Capacidade geral de combinação}

As estimativas dos efeitos da capacidade geral de combinação (CGC) e o desvio padrão do contraste de duas linhagens, relativos as linhagens da população BR-105, BR-106 e BR-105 x BR-106, encontram-se nas Tabelas 11, 12 e 13, respectivamente. As 
estimativas da capacidade de combinação (CGC) das linhagens são importantes para o melhoramento, uma vez que é possível inferir sobre a concentração de alelos favoráveis de efeitos aditivos de cada linhagem. Sendo $p_{i}$ a freqüência de alelos favoráveis da linhagem i e $\bar{p}$ a freqüência média dos alelos favoráveis de todas as linhagens, o conteúdo genético da capacidade de combinação é $\mathrm{CGC}=\sum\left(\mathrm{p}_{\mathrm{i}}-\overline{\mathrm{p}}\right)_{\alpha_{\mathrm{i}}}$, em que $\alpha_{\mathrm{i}}$ é o efeito aditivo dos alelos. Percebe-se que a capacidade de combinação é função direta de uma diferença de freqüências gênicas. Assim, uma linhagem terá capacidade de combinação positiva e elevada quando a sua concentração de alelos favoráveis for superior à freqüência média de alelos favoráveis das linhagens envolvidas nos cruzamentos (Sprague \& Tatum, 1942; Vencovsky, 1987).

$\mathrm{Na}$ avaliação das linhagens a nível intrapopulacional verifica-se para o caráter produção de grãos que $62,5 \%$ das linhagens da população BR-105 apresentaram CGC's diferentes de zero, destacando-se a linhagem 05 com valor superior de CGC que as demais linhagens; para as linhagens derivadas da população BR-106, 100,0\% apresentaram estimativas de CGC diferentes de zero, sendo que nestas destacou-se a linhagem 16 com magnitude de CGC superior às demais. Na avaliação à nível interpopulacional, $72,2 \%$ das linhagens apresentaram estimativas de CGC diferentes de zero, sendo que das oriundas da população BR-105, 75,0\% apresentaram significância e das oriundas da população BR-106, 70,0\% apresentaram significância. Nesta avaliação destacaram-se as linhagens 05 e 15 das populações BR-105 e BR-106, respectivamente. Nota-se, que para a população BR-105 a linhagem superior (05) foi a mesma nas avaliações intra e interpopulacional. Entretanto, para a população BR-106 as linhagens superiores não foram coincidentes nos dois tipos de avaliações, isto é, à nível intrapopulacional destacou-se a linhagem 16 e a nível interpopulacional a linhagem 15 , sendo que a linhagem 16 apresentou valor negativo. Como as estimativas de CGC dependem do conjunto de materiais avaliados, é esperado que estas se alterem quando são avaliadas à nível intra e interpopulacional. Na avaliação das linhagens à nível intrapopulacional a amplitude de variação das CGC's foi de 5,97 e de 13,16 vezes o desvio-padrão nas populações BR-105 e BR-106, respectivamente. Na avaliação das 
linhagens à nível interpopulacional a amplitude de variação das estimativas de CGC foi de 7,86 e de 11,00 vezes o desvio-padrão nas populações BR-105 e BR-106, respectivamente.

$\mathrm{Na}$ avaliação das linhagens à nível intrapopulacional verifica-se para os caracteres altura da planta (AP) e altura da espiga (AE) que 50,0\% das linhagens da população BR-105 apresentaram valores de estimativas de CGC diferentes de zero, sendo que a linhagem 07 para AP e a linhagem 05 para AE apresentaram valores superiores de CGC em relação as demais linhagens. Para as linhagens derivadas da população BR-106, 30,0\% apresentaram estimativas de CGC diferentes de zero tanto para $\mathrm{AP}$ quanto para $\mathrm{AE}$, sendo que em ambos os caracteres destacou-se a linhagem 16 com magnitude de CGC superior às demais. Na avaliação a nível interpopulacional, $77,8 \%$ das linhagens apresentaram estimativas de CGC diferentes de zero para AP, sendo que das oriundas da população BR-105, 75,0\% apresentaram significância e das oriundas da população BR-106, 80,0\% apresentaram significância. Para o caráter AE, $88,9 \%$ das linhagens apresentaram estimativas de CGC diferentes de zero, sendo que das oriundas da população BR-105, 87,5\% apresentaram significância e das oriundas da população BR-106, 90,0\% apresentaram significância. Nesta avaliação destacaram-se as linhagens 06 e 05 da população BR-105 para os caracteres AP e AE, respectivamente. Na população BR-106 destacou-se a linhagem 09 para ambos os caracteres.

Nota-se para a população BR-105 e para o caráter AE que a linhagem superior (05) foi a mesma nas avaliações intra e interpopulacional. Entretanto, para o caráter AP as linhagens superiores não foram coincidentes nos dois tipos de avaliações, isto é, a nível intrapopulacional destacou-se a linhagem 07 e a nível interpopulacional a linhagem 06. Para a população BR-106 as linhagens superiores não foram coincidentes nas avaliações intra e interpopulacional, ou seja, à nível intrapopulacional destacou-se a linhagem 16 para ambos os caracteres e à nível interpopulacional a linhagem 09 para ambos os caracteres. Verifica-se então, que para os caracteres AP e AE ocorreram alterações nas estimativas de CGC quando avaliadas à nível intra $\mathrm{e}$ interpopulacional. Na avaliação das linhagens à nível intrapopulacional a amplitude de variação das CGC's para a população BR-105 foi de 5,09 e de 6,23 vezes o 
desvio-padrão para AP e AE, respectivamente. Para a população BR-106 a amplitude de variação das CGC's foi de 4,09 e de 4,34 vezes o desvio-padrão para $\mathrm{AP}$ e $\mathrm{AE}$, respectivamente. $\mathrm{Na}$ avaliação das linhagens à nível interpopulacional a amplitude de variação dos CGC's foi de 14,25 e de 14,74 vezes o desvio-padrão para $\mathrm{AP}$ e $\mathrm{AE}$, respectivamente na população BR-105 e de 9,54 e de 8,46 vezes o desvio-padrão para AP e AE, respectivamente na população BR-106.

Para o caráter posição relativa da espiga (PRE), na avaliação das linhagens à nível intrapopulacional verifica-se que $37,5 \%$ das linhagens da população BR-105 apresentaram estimativas de CGC diferentes de zero, destacando-se a linhagem $05 \mathrm{com}$ valor superior de CGC que as demais; para as linhagens derivadas da população BR-106, 20,0\% apresentaram estimativas de CGC diferentes de zero, sendo que nestas destacou-se a linhagem 16 com magnitude de CGC superior as demais. Na avaliação à nível interpopulacional, $61,1 \%$ das linhagens apresentaram estimativas de CGC diferentes de zero, sendo que das oriundas da população BR-105, 50,0\% apresentaram significância e das oriundas da população BR-106, 70,0\% apresentaram significância, destacando-se as linhagens 05 e 16 das populações BR-105 e BR-106, respectivamente. Nota-se que, tanto para a população BR-105 quanto para a BR-106, as linhagens 05 (BR-105) e 16 (BR-106) foram superiores nas avaliações intra e interpopulacionais. Na avaliação das linhagens à nível intrapopulacional a amplitude de variação das estimativas de CGC foi de 5,33 e de 4,28 vezes o desvio-padrão nas populações BR-105 e BR-106, respectivamente. $\mathrm{Na}$ avaliação das linhagens à nível interpopulacional a amplitude de variação das estimativas de CGC foi de 10,33 vezes o desvio-padrão nas populações BR-105 e BR-106.

Para o caráter prolificidade (PROL), na avaliação das linhagens à nível intrapopulacional verifica-se que $12,5 \%$ das linhagens da população BR-105 apresentaram estimativas de CGC diferentes de zero, destacando-se a linhagem $01 \mathrm{com}$ valor superior as demais linhagens; para as linhagens derivadas da população BR-106, 10,0\% apresentaram estimativas de CGC diferentes de zero, tendo se destacado a linhagem 13. Na avaliação à nível interpopulacional 50,0\% das linhagens apresentaram estimativas de CGC diferentes de zero, sendo que também tanto as linhagens oriundas 
da população BR-105 quanto as da BR-106, 50,0\% apresentaram significância, destacando-se as linhagens 02 e 13 das populações BR-105 e BR-106, respectivamente. Nota-se que para a população BR-106 a linhagem superior (13) foi a mesma nas avaliações intra e interpopulacional. Entretanto, para a população BR-105 as linhagens superiores não foram coincidentes nos dois tipos de avaliações, sendo a linhagem 01 superior na avaliação intrapopulacional e a linhagem 02 na avaliação interpopulacional. $\mathrm{Na}$ avaliação das linhagens à nível intrapopulacional a amplitude de variação das estimativas de CGC foi de 3,38 e de 2,67 vezes o desvio-padrão nas populações BR-105 e BR-106, respectivamente. Na avaliação das linhagens à nível interpopulacional a amplitude de variação das estimativas de CGC foi de 5,55 e de 7,65 vezes o desviopadrão nas populações BR-105 e BR-106, respectivamente.

Efeitos significativos da CGC, tanto positivos quanto negativos, foram observados nas linhagens tanto nas avaliações intra quanto nas interpopulacionais. Isso mostra que as linhagens derivadas da mesma população podem ter alta ou baixa capacidade geral de combinação. Han et al. (1991) e Gama et al. (1995), também relataram que linhagens derivadas da mesma população podem ter alta ou baixa capacidade geral de combinação. Observando-se todos os contrastes entre as estimativas de CGC para as linhagens das populações BR-105 e BR-106 e na avaliação à nível interpopulacional, constata-se a presença de contrastes diferentes de zero, confirmando com isso, diferenças entre as estimativas.

\subsubsection{Capacidade específica de combinação}

As estimativas dos efeitos da capacidade específica de combinação (CEC) e as médias dos híbridos referentes às linhagens oriundas das populações BR-105 e BR-106 avaliadas à nível intrapopulacional e para as avaliações à nível interpopulacional, para 0 caráter produção de grãos (PG), encontram-se nas Tabelas 14, 19 e 24, respectivamente.

Os efeitos da capacidade específica de combinação são medidas dos efeitos gênicos não aditivos (epistasia e dominância) e portanto, a estimativa da CEC será nula 
se não existir dominância. Considerando-se $p_{i}$ a freqüência do alelo favorável na linhagem i e $r_{j}$ a freqüência desse alelo na linhagem j e $\bar{p}$ e $\bar{r}$ as freqüências médias dos alelos favoráveis em todas as linhagens i e $\mathrm{j}$, respectivamente, o conteúdo genético da capacidade específica de combinação é CEC $=2\left[\left(\bar{p}-p_{i}\right)\left(r_{j}-\bar{r}\right)\right] d$. Portanto, o efeito de CEC será alto se $\bar{p}-p_{i}$ e $r_{j}-\bar{r}$ tiverem o mesmo sinal. Assim, no híbrido obtido pelo cruzamento de duas linhagens, o CEC será alto se a freqüência de alelos favoráveis for alta em uma linhagem e baixa na outra. Baixas capacidades específicas de combinação ocorrerão quando $\overline{\mathrm{p}}-\mathrm{p}_{\mathrm{i}}$ e $\mathrm{r}_{\mathrm{j}}-\overline{\mathrm{r}}$ tiverem sinal trocado, então, o CEC correspondente será negativo (Vencovsky, 1987). Isto acontece quando dois materiais forem semelhantes ou com pouca divergência genética, isto é, tiverem altas ou baixas freqüências alélicas nos mesmos locos. Quando o valor absoluto de CEC é baixo, o comportamento do híbrido depende principalmente dos efeitos das capacidades gerais de combinação dos seus parentais. Por outro lado, quando a estimativa de CEC de um determinado cruzamento tem alto valor absoluto (positivo ou negativo), o comportamento do híbrido é melhor ou pior do que se esperaria baseando-se na capacidade geral de combinação dos respectivos parentais.

$\mathrm{Na}$ avaliação das linhagens à nível intrapopulacional para o caráter produção de grãos verifica-se que $21,4 \%$ das estimativas das capacidades específicas de combinação (CEC) das linhagens da população BR-105 foram diferentes de zero (Tabela 14), destacando-se os híbridos 01x07, 06×08 e 03×06 com valores superiores aos demais e os híbridos 06x07, 03x08 e 01x04 com valores negativos e diferentes de zero. A média de produção dos híbridos foi de 6,59t/ha, sendo que as médias variaram de 4,37 t/ha a 8,26 $\mathrm{t} / \mathrm{ha}$. Verifica-se que o híbrido que apresentou a maior estimativa de $\operatorname{CEC}(1,175 \mathrm{t} / \mathrm{ha})$ também foi o mais produtivo $(8,26 \mathrm{t} / \mathrm{ha})$. Os híbridos $06 \times 07$ e $03 \times 08$ que apresentaram os mais baixos valores de CEC apresentaram as menores médias, sendo, 4,37 t/ha e 4,57 t/ha, respectivamente. Para as linhagens oriundas da população BR-106 (Tabela 19), verifica-se estimativas de CEC diferentes de zero para 14 cruzamentos, o que corresponde a $34,1 \%$ dos híbridos avaliados, destacando-se o cruzamento $09 \times 18$ com valor superior de $\mathrm{CEC}$ que os demais híbridos. $\mathrm{O}$ valor negativo de $\mathrm{CEC}$ mais acentuado 
foi observado no cruzamento das linhagens $09 \times 10$. A média de produção dos híbridos foi de $6,13 \mathrm{t} / \mathrm{ha}$, oscilando de $1,49 \mathrm{t} / \mathrm{ha}$ a 7,84 tha. $\mathrm{O}$ cruzamento das linhagens $11 \times 12$ foi considerado como tendo efeito de CEC igual a zero, pois são linhagens irmãs. Esse alto grau de parentesco entre essas duas linhagens pode ser confirmado através da média de produção do híbrido que foi de 1,49 t/ha. $\mathrm{Na}$ avaliação das linhagens à nível interpopulacional (Tabela 24) nota-se que 5,0\% dos cruzamentos apresentaram estimativas de CEC diferentes de zero, destacando-se os híbridos 04x09 e 05x16 com

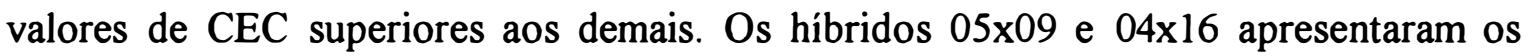
valores negativos mais acentuados de CEC, sendo que esses também apresentaram baixa produção de grãos. A média de produção dos híbridos interpopulacionais foi de 6,80 t/ha, variando de 3,81 t/ha a $8,30 \mathrm{t} / \mathrm{ha}$. Verifica-se que a produção dos híbridos interpopulacionais superou a dos intrapopulacionais. Naspolini $\mathrm{F}^{\mathbf{0}}$ et al. (1981) e Souza Jr. et al. (1993) reportaram valores elevados de heterose para o cruzamento destas populações. Assim já era esperado que o híbridos interpopulacionais fossem mais produtivos que os intrapopulacionais. Observando-se os contrastes das estimativas de CEC verifica-se contrastes diferentes de zero tanto à nível intra como interpopulacional. Nota-se também que, no geral, os híbridos mais produtivos possuem ao menos uma linhagem com valores altos para a capacidade geral de combinação.

As estimativas dos efeitos das capacidades específicas de combinação (CEC) e as médias dos híbridos referentes às linhagens oriundas das populações BR-105 e BR-106 avaliadas à nível intrapopulacional e para as avaliações à nível interpopulacional, para o caráter altura da planta (AP), estão nas Tabelas 15, 20 e 25, respectivamente. Na avaliação das linhagens à nível intrapopulacional observa-se que $14,3 \%$ das estimativas de CEC relativas aos cruzamentos das linhagens oriundas da população BR-105 foram diferentes de zero (Tabela 15), destacando-se os híbridos $05 \times 07$ e $02 \times 05$ com valores de CEC superiores aos demais híbridos. A média da altura das plantas dos híbridos foi de $210,01 \mathrm{~cm} /$ planta, oscilando de 194,19 cm/planta a $239,89 \mathrm{~cm} /$ planta. Nota-se que o híbrido que apresentou a maior estimativa de $\operatorname{CEC~}(15,300 \mathrm{~cm} /$ planta $)$ também apresentou a maior altura de planta $(239,89 \mathrm{~cm} /$ planta). Para as linhagens oriundas da população BR-106 (Tabela 20), obtiveram-se estimativas de CEC diferentes de zero para 
4,9\% dos híbridos avaliados, destacando-se os híbridos $14 \times 16$ e $11 \times 15$ com valores de CEC superiores aos demais. A média da altura das plantas dos híbridos foi de 206,38 $\mathrm{cm} /$ planta, sendo que essas variaram de $194,70 \mathrm{~cm} /$ planta a $225,23 \mathrm{~cm} /$ planta. $\mathrm{Na}$ avaliação à nível interpopulacional (Tabela 25) observa-se que 5,0\% das estimativas de CEC foram diferentes de zero, destacando-se os híbridos $04 \times 14$ e $06 \times 18$, os quais apresentaram valores superiores aos demais híbridos. Os híbridos 04x16 e 08x09 apresentaram valores negativos e diferentes de zero. A média da altura das plantas nos cruzamentos interpopulacionais foi de $206,61 \mathrm{~cm} /$ planta, variando de $188,43 \mathrm{~cm} /$ planta a $229,79 \mathrm{~cm} /$ planta. Observando-se os contrastes entre as estimativas de CEC tanto à nível intra como interpopulacional, verifica-se estimativas diferentes de zero para os contrastes.

As estimativas dos efeitos das capacidades específicas de combinação (CEC) e as médias dos híbridos referentes às linhagens oriundas das populações BR-105 e BR-106 e para os cruzamentos interpopulacionais, para o caráter altura da espiga (AE), encontramse nas Tabelas 16, 21 e 26, respectivamente. Na avaliação das linhagens à nível intrapopulacional nota-se que $17,8 \%$ das estimativas de CEC das linhagens oriundas da população BR-105 foram diferentes de zero (Tabela 16), sendo o maior valor (12,343 $\mathrm{cm} /$ planta) observado no cruzamento das linhagens $05 \times 07$. A média do caráter AE foi de $110,27 \mathrm{~cm} /$ planta, oscilando entre 97,98 cm/planta e $132,51 \mathrm{~cm} /$ planta. Nas linhagens oriundas da população BR-106 (Tabela 21) não foram obtidas estimativas de CEC diferentes de zero. A média da altura da espiga foi de 106,77 cm/planta, variando entre $97,46 \mathrm{~cm} /$ planta a $117,05 \mathrm{~cm} /$ planta. Na avaliação à nível interpopulacional (Tabela 26), observa-se que $3,75 \%$ das estimativas de CEC foram diferentes de zero, destacando-se o híbrido $04 \times 14$ que apresentou valor superior aos demais híbridos avaliados. A média da altura da espiga foi de $106,21 \mathrm{~cm} /$ planta oscilando entre $93,58 \mathrm{~cm} /$ planta e 120,65 $\mathrm{cm} /$ planta. Observando-se os contrastes das estimativas de CEC nota-se que existem diferenças significativas entre as estimativas. Nota-se tanto para o caráter AE como para o AP que as médias foram maiores para as linhagens da população BR-105 avaliadas à nível intrapopulacional, superando as médias das linhagens da população BR-106 e nas avaliações interpopulacionais. 
As estimativas dos efeitos das capacidades específicas de combinação (CEC) e as médias dos híbridos referentes às linhagens oriundas das populações BR-105 e BR-106 avaliadas à nível intrapopulacional e para os cruzamentos interpopulacionais, para os caracteres posição relativa da espiga (PRE) e prolificidade (PROL), encontram-se nas Tabelas 17, 18, 22, 23, 27 e 28, respectivamente. Para o caráter PRE, na avaliação das linhagens à nível intrapopulacional, 25,0\% das estimativas de $\mathrm{CEC}$ apresentaram valores diferentes de zero na população BR-105 (Tabela 17), onde o maior valor de CEC foi encontrado para o híbrido $02 \times 05(0,023)$. A média do caráter PRE foi de 0,52 , variando entre 0,46 e 0,54. Nas linhagens oriundas da população BR-106 e na avaliação interpopulacional, não foram observadas estimativas de CEC diferentes de zero (Tabelas 22 e 27). A média de PRE tanto para as linhagens da população BR-106 avaliadas a nível intrapopulacional quanto para os cruzamentos interpopulacionais foi de 0,51 . Para o caráter PROL, na avaliação das linhagens à nível intrapopulacional, verifica-se que $10,7 \%$ das estimativas de CEC referente às linhagens da população BR-105 foram diferentes de zero (Tabela 18), destacando-se o cruzamento das linhagens $05 \times 06$, que apresentou estimativa de CEC maior que os demais. A média do caráter prolificidade foi de 1,07 espigas/planta, variando de 0,91 espigas/planta a 1,26 espigas/planta. Na população BR-106, somente o cruzamento das linhagens $09 \times 18$ apresentou estimativa de CEC diferente de zero, o que corresponde a $2,4 \%$ dos híbridos avaliados. A média foi de 1,02 espigas/planta, variando entre 0,72 espigas/planta e 1,22 espigas/planta. $\mathrm{Na}$ avaliação à nível interpopulacional não observou-se estimativas de CEC diferentes de zero. Observando os contrastes entre os híbridos, nota-se que existem diferenças entre as estimativas de CEC para ambos os caracteres tanto à nível intra como interpopulacional.

\subsection{Grupos heteróticos}

Os grupos heteróticos foram formados baseando-se nas estimativas das capacidades específicas de combinação (CEC) as quais foram submetidas às análises de agrupamento e de coordenadas principais. As estimativas de CEC foram consideradas como medidas de divergência genética entre as linhagens, sendo que cruzamentos com 
efeitos de CEC positivos significam que as linhagens pertencem a grupos heteróticos opostos e cruzamentos com efeitos de CEC negativos significam que pertencem ao mesmo grupo heterótico. Verifica-se assim, que mediante aos efeitos de CEC somente poderão ser formados dois grupos heteróticos, ou seja, grupos I e II. Porém, com auxílio das análises de agrupamento e de coordenadas principais, mais de dois grupos heteróticos poderão ser formados. A separação de linhagens em grupos heteróticos baseando-se em estimativas de capacidade específica de combinação tem sido amplamente utilizada no melhoramento de milho, embora sem utilizar análises de agrupamento e de coordenadas principais (Vasal et al., 1992c,d; Gonzalez et al., 1997; Terron et al., 1997).

Os grupos heteróticos formados a partir das estimativas de capacidade específica de combinação foram comparados com aqueles formados a partir das distâncias genéticas obtidas por marcadores RFLP. Para melhor acompanhamento, os resultados e discussão serão feitos para cada caráter separadamente, dando-se mais ênfase para produção de grãos que é o caráter de maior importância.

\subsubsection{Produção de grãos (PG)}

Para as linhagens oriundas da população BR-105 e avaliadas à nível intrapopulacional, as estimativas dos efeitos de CEC encontram-se na Tabela 14. A separação das linhagens dessa população em grupos heteróticos iniciou-se a partir do maior valor positivo de CEC. O híbrido $01 \times 07$ apresentou o maior efeito de CEC $(1,175$ t/ha) e com alta significância, o qual representa ser o melhor indicador a ser utilizado para o agrupamento em cada um dos grupos heteróticos (GI e GII), considerando-se então a linhagem 01 para GI e a linhagem 07 para GII. As capacidades específicas de combinação da linhagem $01 \mathrm{com}$ as demais, apresentou efeito positivo somente com a 02 , indicando que essa pertence ao GII. As estimativas de CEC que mostraram efeitos negativos foram com a $03,04,05,06$ e a 08 , o que significa que pertencem ao GI, destacando-se a linhagem 04 que apresentou estimativa de CEC diferente de zero. 
Observando-se as estimativas de CEC obtidas do cruzamento da linhagem $07 \mathrm{com}$ as outras linhagens, as que mostraram efeitos positivos foram com a $03,04,05$ e a 08 e com as linhagens restantes mostraram efeitos negativos, destacando-se o cruzamento com a linhagem 06, em que a estimativa de CEC foi altamente significativa. A linhagem 06 que apresentou estimativas negativas de CEC em cruzamentos tanto com a linhagem 01 como com a linhagem 07 , apresentou significância somente com a linhagem 07. Observando-se o comportamento da linhagem 06 em relação as outras linhagens, verifica-se que quando cruzada com as linhagens 03 e 08 (ambas de GI) apresentou efeito positivo e significativo, sendo agrupada portanto em GII (Tabela 14). Após a análise das estimativas de CEC, verifica-se que GI foi composto pelas linhagens 01,03 , 04, 05 e 08 e GII pelas linhagens 02, 06 e 07.

$\mathrm{Na}$ análise de agrupamento utilizando-se o método UPGMA, a partir da matriz das estimativas de CEC (Figura 1), verifica-se que foram formados dois grupos heteróticos idênticos aos obtidos utilizando-se o critério relatado anteriormente. No dendograma visualiza-se claramente a formação dos grupos, sendo GI formado pelas linhagens 01, 03, 04, 05 e 08 e GII pelas linhagens 02, 06 e 07. As análises de coordenadas principais a partir das estimativas de CEC revelaram os mesmos resultados, os quais podem ser observados na Figura 3. No gráfico em três dimensões a visualização dos grupos não é muito clara, porém nos gráficos com somente dois eixos, a visualização é facilitada. As três primeiras coordenadas principais explicaram $56,6 \%$ da variância total e apesar de não terem explicado toda a variância, essas refletiram o mesmo padrão de associação das linhagens observado no dendograma. Verifica-se então, que os três critérios utilizados foram eficientes para alocar as linhagens em grupos heteróticos a partir das estimativas de CEC.

Comparando-se as médias de produção dos híbridos de cada grupo, observa-se para GI, GII e GIxGII, que as médias foram de 6,46 t/ha, de 5,32 t/ha e de 6,97 t/ha, respectivamente (Tabela 30 ). Nota-se que a média do cruzamento entre os grupos, apesar da pequena diferença, foi maior do que a média de cada grupo e da média considerando todas as linhagens. Os valores médios das estimativas de CEC foram negativos para os grupos e positivo para o cruzamento entre os grupos, indicando que as 
linhagens dos diferentes grupos combinam melhor quando cruzadas entre si do que dentro de cada grupo. O GII foi o que apresentou a menor produção e também o menor valor médio de CEC (-1,029 t/ha). Considerando-se os grupos formados a partir das estimativas de CEC, utilizou-se os valores das distâncias genéticas obtidas por marcadores RFLP (Tabela 29) para calcular as distâncias genéticas médias de todas as linhagens, de cada grupo e do cruzamento entre os grupos (Tabela 30). Nota-se, que as distâncias foram semelhantes para os grupos, para os cruzamentos entre os grupos e quando todas as linhagens foram consideradas. As correlações entre distância genética (DG) com a capacidade específica de combinação (CEC) foram não significativas para GI, GIxGII e para o cruzamento envolvendo todas as linhagens. Somente para o GII essa correlação foi significativa, porém, o número de linhagens era muito baixo (Tabela 30).

Os grupos formados a partir das distâncias genéticas obtidas por marcadores RFLP utilizando-se as análises de agrupamento (UPGMA) e de coordenadas principais encontram-se nas Figuras 30 e 32. Observa-se a formação de dois grupos, sendo um composto pelas linhagens 01,02,03,04, 05 e 08, e o outro, pelas linhagens 06 e 07 . Considerando-se esse agrupamento e calculando a média de produção dos híbridos de cada grupo, observa-se para GI, GII e GIxGII, que as médias foram de 6,48 t/ha, de 4,37 t/ha e de 6,95 t/ha, respectivamente. Observa-se que a média do cruzamento entre os grupos foi maior do que as médias dos grupos. Comparando-se os grupos formados a partir das distâncias genéticas (Figura 30) com aqueles formados a partir das estimativas de CEC (Figura 1) verifica-se que os resultados foram semelhantes, com exceção da linhagem 02, cujo comportamento não foi coincidente. Observando-se as distâncias genéticas (Tabela 29), nota-se que a linhagem 02 estava realmente mais distante das linhagens 06 e 07 . Através da análise de coordenadas principais pode-se confirmar o mesmo resultado, onde verifica-se que as linhagens 06 e 07 formam um grupo separado das demais linhagens (Figura 32). Portanto, verifica-se uma discordância entre as estimativas de CEC e distância genética para a linhagem 02 da população BR-105.As três primeiras coordenadas principais explicaram $70,6 \%$ da variância total, refletindo uma confiável distribuição das linhagens aos grupos heteróticos. Considerando-se que os agrupamentos formados a partir das estimativas de CEC e os agrupamentos com 
distâncias genéticas diferem apenas em relação à linhagem 02 , a coincidência de resultados é de $87,5 \%$, mostrando que os marcadores RFLP foram eficientes na alocação das linhagens em grupos heteróticos para esta população.

Para as linhagens oriundas da população BR-106 e avaliadas à nível intrapopulacional, as estimativas dos efeitos de CEC encontram-se na Tabela 19. A maior estimativa de CEC (1,821 t/ha) e com alta significância ocorreu para o híbrido 09x18, sendo essas linhagens utilizadas para a formação dos grupos heteróticos (GI e GII), considerando a linhagem 09 para GI e a linhagem 18 para GII. No cruzamento da linhagem 09 com as outras linhagens, as estimativas de CEC com efeitos positivos foram com as linhagens 11,12 e 14, o que significa que essas linhagens pertencem ao GII, sendo que somente com a linhagem 12 a estimativa de CEC foi significativa. As combinações que resultaram em efeitos negativos foram com a 10,13, 15 e 17, o que significa que pertencem ao GI, sendo que com as linhagens 10 e 13 apresentaram alta significância e com a linhagem 15, o efeito de CEC foi praticamente nulo. Observandose as capacidades de combinação da linhagem 18 com as outras linhagens, as que mostraram efeitos positivos foram com a 10 e 13 e, com as linhagens $11,12,14,15$, e 17 , as estimativas foram negativas. A linhagem 17 apresentou efeitos negativos tanto com a linhagem 09 quanto com a linhagem 18, sendo que o valor mais acentuado $(-0,999 \mathrm{t} / \mathrm{ha})$ foi com a linhagem 18 (GII). Comparando-se os cruzamentos da linhagem 17 com as demais, verifica-se que essa apresentou efeitos positivos com as linhagens 10 , 12,13 e 15, sendo estimativas diferentes de zero com as linhagens 10 e 13 (ambas de GI) e apresentou altos valores negativos com as linhagens 11 e 14 (ambas de GII). Portanto, decidiu-se agrupar a linhagem 17 em GII. A linhagem 15 comportou-se de maneira semelhante à linhagem 17, ou seja, apresentou valores negativos com as linhagens 09 e 18, entretanto, com a linhagem 09, o efeito foi quase nulo. Verificando-se o comportamento da linhagem 15 , nota-se que essa apresentou efeitos positivos com as linhagens $11,12,14$ e 17 (ambas de GII) e negativos com a 10 e 13 (ambas de GI), indicando assim, que a linhagem 15 pertence ao GI. Após a análise das estimativas de CEC, o GI foi formado pelas linhagens $09,10,13$ e 15 e o GII pelas linhagens 11, 12, 
14,17 e 18. Devido à falhas em alguns cruzamentos, a linhagem 16 foi desconsiderada na formação dos grupos heteróticos.

$\mathrm{Na}$ análise de agrupamento (UPGMA) a partir da matriz das estimativas de CEC (Figura 2) verifica-se a formação de dois grupos heteróticos idênticos aos obtidos através do critério que se baseia na maior estimativa de CEC, ou seja, foram formados dois grupos heteróticos, sendo GI composto pelas linhagens 09, 10, 13 e 15 e GII pelas linhagens $11,12,14,17$ e 18. A análise de coordenadas principais a partir da matriz de estimativas de CEC (Figura 4) resultou na formação dos mesmos dois grupos heteróticos, em que as três primeiras coordenadas principais explicaram $63,0 \%$ da variação total dos dados. Semelhante ao que ocorreu com a população BR-105, a análise de coordenadas principais refletiu o mesmo padrão de associação das linhagens verificado no dendograma e no critério que se baseia no maior valor da CEC.

Comparando-se as médias dos grupos heteróticos, verifica-se que a média do GI foi de 7,08 t/ha, a média do GII foi de 4,90 t/ha e a média intergrupos (GI x GII) foi de 6,76 t/ha (Tabela 31). A maior média foi obtida pelos híbridos do GI, entretanto esta foi semelhante a média do cruzamento de GIxGII. Percebe-se também, que a média de GII foi muito baixa, sendo que uma das causas dessa baixa produção é a presença das linhagens irmãs 11 e 12, as quais resultaram em um híbrido pouco produtivo. A média de todas as linhagens (5,95 t/ha) ficou abaixo das médias de GI e de GI x GII, mostrando que as linhagens podem ser separadas em grupos heteróticos. As médias das estimativas de CEC comportaram-se de modo semelhante às da população BR-105, sendo os efeitos negativos para os grupos e positivo para o cruzamento entre grupos. Observando-se as médias das distâncias genéticas calculadas para cada grupo, para o cruzamento entre os grupos e para todas as linhagens, nota-se que o GII, o qual apresentou a menor produção, também apresentou a menor distância genética média, seguido pela distância genética considerando-se todas as linhagens. Observa-se que as maiores distâncias genéticas coincidem com as maiores produções. As correlações entre distância genética (DG) com a capacidade específica de combinação (CEC) foram altamente significativas quando todas as linhagens foram consideradas, sendo que para GI, GII e GIxGII foram não significativas. 
Os grupos heteróticos formados para as linhagens oriundas da população BR-106 por meio das análises de agrupamento e de coordenadas principais a partir das distâncias genéticas obtidas por marcadores RFLP estão nas Figuras 33 e 35. Observando-se o dendrograma (Figura 33) e desconsiderando-se a linhagem 16, verifica-se a formação de dois grupos heteróticos, sendo o grupo I (GI) formado pelas linhagens 09, 10 e 13 e o grupo II (GII) pelas linhagens 11, 12, 14, 15, 17 e 18. Nota-se que a linhagem 15, apesar de estar relacionada com GII no dendrograma, encontra-se mais distante das demais linhagens de GII. Isso é confirmado através da análise de coordenadas principais (Figura 35), onde a linhagem 15 ocupa uma posição intermediária entre os dois grupos, sugerindo estar mais próxima de GI do que de GII. Porém, não se pode afirmar corretamente a posição da linhagem 15 baseando-se apenas na análise de coordenadas principais, pois as três primeiras coordenadas principais explicaram apenas $62,9 \%$ da variação total. Considerando-se os grupos formados a partir das distâncias genéticas obtidas por RFLP em que o GI é formado pelas linhagens 09, 10 e 13 e o GII pelas linhagens $11,12,14,15,17$ e 18, e obtendo-se a média de produção dos híbridos de cada grupo, observa-se para GI, GII e GIxGII, que as médias foram 6,87 t/ha, 5,70 t/ha e 6,94 t/ha, respectivamente. Comparando-se os grupos formados a partir das estimativas de CEC (Figura 2) com os grupos formados a partir das distâncias genéticas obtidas de marcadores RFLP (Figura 33), verifica-se uma semelhança nos resultados. Com exceção da linhagem 16, os grupos heteróticos formados pelas distâncias genéticas diferem dos grupos heteróticos de CEC apenas em relação a linhagem 15. Considerando-se que os agrupamentos a partir das estimativas de CEC e os de distâncias genéticas diferem apenas em relação a linhagem 15 , a coincidência de resultados é de $94,1 \%$. Porém, considerando-se a linhagem 15 como pertencente ao grupo I, a coincidência de resultados é de 100,0\%, mostrando que os marcadores RFLP foram eficientes na alocação das linhagens em grupos heteróticos para esta população.

As estimativas de CEC das linhagens oriundas da população BR-105 em cruzamentos com as linhagens da população BR-106 encontram-se na Tabela 24 . Devido ao grande número de linhagens, torna-se dificil a separação dos grupos heteróticos a partir do maior valor da estimativa de CEC. Então, os grupos heteróticos 
foram formados baseando-se principalmente nas análises de agrupamento (Figura 5) e de coordenadas principais (Figura 7) realizadas com as estimativas de CEC. Deve-se ressaltar também, que para separar as linhagens é preciso utilizar as estimativas obtidas nas análises intrapopulacionais. Observando-se o dendograma (Figura 5), verifica-se que foram formados quatro grupos heteróticos (GI, GII, GIII e GIV), sendo o GI composto pelas linhagens 01, 03, 04, 05 e 08; o GII pelas linhagens 09, 10, 13 e 15; o GIII pelas linhagens 02, 06 e 07; e o GIV pelas linhagens 11, 12, 14, 17 e 18. Esse mesmo resultado também é confirmado através das análises de coordenadas principais (Figura 7). Devido ao grande número de linhagens no gráfico em três dimensões, a visualização dos grupos não é muito clara. Porém, no gráfico com dois eixos torna-se mais fácil a visualização dos grupos, onde vê-se claramente a separação das linhagens da população BR-106 em dois grupos. Para as linhagens da população BR-105 a separação ficou mais clara quando se considerou as duas primeiras coordenadas principais $(25,2 \%)$. As três primeiras coordenadas principais refletiram apenas $34,8 \%$ da variação total. Portanto, na separação das linhagens em grupos heteróticos também deve-se levar em consideração a análise de agrupamento a qual é visualizada por meio do dendograma. Ressalta-se, que a linhagem 16 também foi desconsiderada nesses grupos.

As médias de produção de cada grupo e dos cruzamentos entre os grupos encontram-se na Tabela 32. Observa-se que as médias dos cruzamentos intergrupos superaram as médias dos grupos, com exceção do grupo II. A média dos cruzamentos envolvendo todas as linhagens também foi inferior às médias dos cruzamentos intergrupos, mostrando que a realização de determinados cruzamentos dirigidos resultariam em melhores híbridos. As estimativas médias de CEC foram negativas para todos os grupos e também para os cruzamentos GIxGII e GIIIxGIV, sendo que para esses cruzamentos a CEC foi de baixa magnitude. As distâncias genéticas foram em média, mais altas para os cruzamentos entre grupos do que dentro de cada grupo. $\mathrm{O}$ cruzamento GIIIxGIV foi o que apresentou a maior produção e também a maior distância genética. As correlações entre distância genética (DG) com a capacidade específica de combinação (CEC) foram todas não significativas (Tabela 32). 
Os grupos heteróticos formados para as linhagens das populações BR-105 e BR106 por meio das análises de agrupamento (UPGMA) e de coordenadas principais utilizando-se as distâncias genéticas obtidas por marcadores RFLP encontram-se nas Figuras 34 e 36 . Observa-se que as linhagens foram divididas em quatro grupos, sendo GI formado pelas linhagens $01,02,03,04,05$, e 08; GII pelas linhagens 06 e 07; GIII pelas linhagens 09, 10 e 13; e GIV pelas linhagens $11,12,14,15,17$ e 18. Observandose o gráfico em três dimensões (Figura 36), a a locação das linhagens 17 e 18 no grupo das linhagens 11, 12 e 14 não é muito clara, mas observando-se o gráfico com dois eixos, verifica-se que no eixo que explica a maior porção da variância (PCO1) essas linhagens estão na mesma linha. Esse grupo heterótico também é confirmado na análise de agrupamento (Figura 34). Os marcadores RFLP foram eficientes pois separaram as duas populações (Figura 34) e também as linhagens dentro de cada população, visto que os grupos I e II referem-se às linhagens da população BR-105 e os grupos III e IV referem-se as linhagens da população BR-106. Utilizando-se marcadores RAPD nas mesmas 18 linhagens, Lanza et al. (1997) reportaram resultados semelhantes, sendo que os marcadores separaram essas linhagens em três grupos, em que a população BR-106 foi dividida em dois grupos diferentes e a população BR-105 permaneceu como um único grupo.

Comparando-se os grupos heteróticos a partir de estimativas de CEC (Figuras 5 e 7) com os grupos obtidos a partir de marcadores RFLP (Figuras 34 e 36), percebe-se que os resultados foram semelhantes. Observando-se os dados de CEC (Figuras 5 e 7), a população BR-106 também foi dividida em dois grupos (GII e GIV). Nota-se que os dados de CEC são muito próximos aos observados com distância genética, com exceção da linhagem 15. No agrupamento das linhagens a partir das distâncias genéticas (Figura 34) a presença da linhagem 15 no grupo 4 não foi muito consistente. Esse resultado pode ser confirmado por meio da análise de coordenadas principais (Figura 36), onde a linhagem 15 aparece mais próxima das linhagens 09,10 e 13, idêntico ao agrupamento utilizando-se estimativas de CEC. Embora as três primeiras coordenadas principais tenham refletido apenas $44,36 \%$ da variância total, a separação das linhagens é bastante clara. A análise de Bootstrap (Figura 37) confirma esse resultado, onde verifica-se que a 
porcentagem de vezes em que a linhagem 15 agrupou-se com as linhagens $11,12,14,17$ e 18 foi de somente $67,9 \%$. Portanto, a linhagem 15 poderia estar associada ao grupo III e não ao grupo IV.

As linhagens da população BR-105 também foram divididas em dois grupos a partir das estimativas de CEC, sendo o GI composto pelas linhagens 01, 03, 04, 05 e 08 e o GII pelas linhagens 02, 06 e 07. Sendo assim, os resultados de CEC e distâncias genéticas para a população BR-105 estariam diferindo apenas em relação a linhagem 02 . Observa-se na Figura 37, que realmente a linhagem 02 está mais próxima das linhagens 01, 03, 04, 05 e 08 que das linhagens 06 e 07, como ocorreu com agrupamento obtido com as estimativas de CEC.

Pelo que foi relatado acima, considerando-se que as linhagens 02 e 15 estão diferindo, verifica-se uma coincidência entre as estimativas de CEC e distâncias genéticas de $88,2 \%$, isto é, $88,2 \%$ das linhagens foram alocadas no mesmo grupo heterótico por meio de estimativas de CEC e marcadores RFLP. Além disso, como a linhagem 15 poderia ser alocada no grupo heterótico III, essa coincidência é de $94,1 \%$. Verifica-se então, que mesmo com algumas diferenças na alocação das linhagens aos grupos heteróticos e as correlações não significativas entre distância genética e CEC, a porcentagem de coincidências foi alta. A falta de significância das correlações foi devido as posições das linhagens nos grupos heteróticos, ou seja, observando-se as Figuras 5 e 34 , verifica-se que a posição das linhagens dentro dos grupos é diferente. Existe uma relação entre distância genética e CEC dentro dos grupos, mas a ordem dessa relação não é a mesma para os dois parâmetros. Então, apesar das correlações não serem significativas, as linhagens foram alocadas nos mesmos grupos heteróticos a partir das estimativas de CEC e distâncias genéticas. Portanto, verifica-se que os marcadores RFLP foram eficientes na alocação das linhagens das populações BR-105 e BR-106 avaliadas à nível interpopulacional. Como os agrupamentos à nível intra e interpopulacional foram coincidentes, torna-se desnecessário a realização das análises à nível intrapopulacional. 


\subsubsection{Altura da planta (AP)}

As estimativas dos efeitos de CEC das linhagens oriundas da população BR-105 avaliadas à nível intrapopulacional estão na Tabela 15. O híbrido $05 \times 07$ apresentou o maior efeito de CEC e altamente significativo, considerando-se então a linhagem 05 para GI e a linhagem 07 para GII. Observando-se as combinações da linhagem $05 \mathrm{com}$ as outras linhagens, as que mostraram efeitos positivos foram a 02,04 e a 06 , indicando que pertencem a GII, sendo que com a linhagem 02 a estimativa de CEC foi diferente de zero. As linhagens que mostraram efeitos negativos em cruzamentos com a 05 foram a 01,03 e a 08 , em que a combinação com a linhagem 08 mostrou-se significativa, indicando que pertencem a GI. Verificando-se o cruzamento da linhagem $07 \mathrm{com}$ as demais, as que mostraram efeitos positivos de CEC foram com a 01, 02, 03 e 08, indicando que pertencem a GI, em que ambas não foram diferentes de zero. As estimativas de CEC negativas foram com a 04 e 06, destacando-se com a linhagem 06 que apresentou um valor negativo de CEC muito acentuado. Baseando-se nas estimativas de CEC (Tabela 15), na análise de agrupamento (Figura 6) e na análise de coordenadas principais (Figura 8), decidiu-se a formação de dois grupos heteróticos, sendo o GI formado pelas linhagens 01, 02, 04, 05 e 08 e GII pelas linhagens 03, 06 e 07. As três primeiras coordenadas principais explicaram $59,0 \%$ da variância total.

Comparando-se a altura média das plantas de cada grupo (Tabela 33), observa-se para GI, GII e GIxGII, que as médias foram de 208,20 cm/planta, 202,42 cm/planta e $217,74 \mathrm{~cm} /$ planta, respectivamente. Verifica-se que a média do cruzamento GIxGII foi maior que a média dos grupos e maior que a média de todas as linhagens. Isso é confirmado através das estimativas de $\mathrm{CEC}$, as quais foram negativas para os grupos e positiva para o cruzamento intergrupo. Nota-se também, que a distância genética para GIxGII $(0,78)$ é maior do que as demais. As correlações entre estimativas de CEC e distâncias genéticas foram significativas apenas para GII, porém o número de linhagens era muito pequeno. Comparando-se esses resultados com os dados de distância genética (Figuras 30 e 32), verifica-se que apenas a linhagem 03 comportou-se de maneira diferente. Esses resultados também diferenciaram um pouco daqueles obtidos para 
produção de grãos, onde o GII era formado pelas linhagens 02,06 e 07 e não pelas linhagens 03, 06 e 07. Portanto, verifica-se que a alocação das linhagens em grupos heteróticos a partir das estimativas de CEC não foi muito eficiente para o caráter altura da planta. Entretanto, a concordância entre os grupos formados a partir de CEC e distância genética foi de $87,5 \%$, mostrando que os marcadores moleculares foram eficientes na alocação das linhagens em grupos heteróticos distintos nesta população para o caráter AP.

$\mathrm{Na}$ população BR-106, somente os cruzamentos das linhagens $11 \times 15$ e $14 \times 16$ apresentaram estimativas de CEC diferentes de zero a $5 \%$ de probabilidade pelo teste $t$ (Tabela 20). Baseando-se nas estimativas de CEC, nas análises de agrupamento (Figura 9) e de coordenadas principais (Figura 11), percebe-se a formação de dois grupos heteróticos, sendo o GI composto pelas linhagens 09, 11, 12 e 17 e o GII pelas linhagens $10,13,14,15$ e 18. As três primeiras coordenadas principais explicaram $57,3 \%$ da variância total. Nos gráficos de coordenadas principais, a posição das linhagens 09 e 17 não é muito nítida, porém, com o auxílio do dendograma, essas foram alocadas no grupo I. A altura média das plantas foi maior para o cruzamento GIxGII $(206,84 \mathrm{~cm} /$ planta $)$, superando as médias dos grupos e a média de todas as linhagens (Tabela 34). A estimativa de CEC também foi positiva para GIxGII. A distância genética não seguiu o mesmo padrão, ou seja, as distâncias de GII foi maior do que a distância genética de GIxGII. As correlações entre estimativas de CEC e distâncias genéticas foram todas não significativas.

Comparando-se os agrupamentos formados a partir das estimativas de CEC com os agrupamentos formados a partir das distâncias genéticas, verifica-se que eles foram contrastantes (Figuras 33 e 35). Os grupos heteróticos formados a partir das estimativas de CEC para o caráter AP também foram contrastantes em relação ao caráter produção de grãos. Então, a alocação das linhagens em grupos heteróticos utilizando-se estimativas de CEC e marcadores RFLP não foi eficiente para o caráter altura da planta nessa população, isto é, não foi possível discriminar as linhagens utilizando-se as estimativas de CEC. 
Observando-se as estimativas de CEC das linhagens oriundas da população BR105 em cruzamentos com as linhagens da população BR-106 (Tabela 25) verifica-se que quatro híbridos apresentaram estimativas diferentes de zero. Nos híbridos $04 \times 16$ e $08 \times 09$ as estimativas foram negativas e nos híbridos $04 \times 14$ e $06 \times 18$, o valor de CEC foi positivo. Com o auxílio da análise de agrupamento (Figura 10) e da análise de coordenadas principais (Figura 12), foram formados três grupos heteróticos, sendo o grupo 1 (GI) composto pela linhagens $01,02,04,11,12$ e 18; o GII pelas linhagens 05 , 08, 09 e 17; e o GIII pelas linhagens 03,06, 07, 10,13,14 e 15. As três primeiras coordenadas principais explicaram $33,6 \%$ da variância total. Devido à pequenas diferenças na magnitude das estimativas a visualização dos grupos não ficou muito definida. As médias dos grupos, dos cruzamentos entre os grupos e de todas as linhagens encontram-se na Tabela 35. Nota-se que as médias dos cruzamentos entre os grupos foram maiores que as médias de cada grupo e que a média de todas as linhagens. As estimativas de CEC foram negativas para os grupos e positivas para os cruzamentos entre grupos. As distâncias genéticas não seguiram o mesmo resultado, apresentando valores inferiores em alguns cruzamentos entre os grupos. As correlações entre distâncias genéticas com estimativas de CEC foram todas não significativas. Comparando-se os dados de CEC (Figuras 10 e 12) com as distâncias genéticas (Figuras 34 e 36) verifica-se uma discordância de resultados. Nota-se que ocorreu uma mistura das linhagens das populações BR-105 e BR-106, e os grupos formados não representam um padrão heterótico definido. Verifica-se então, que a alocação das linhagens em grupos heteróticos utilizando-se marcadores RFLP não foi eficiente para o caráter altura da planta quando as linhagens das populações BR-105 e 106 foram avaliadas em cruzamentos. De acordo com os resultados, verifica-se que apesar de o uso dos marcadores ter sido eficiente para as linhagens da população BR-105, os grupos formados para as linhagens da população BR-106 e para as linhagens avaliadas em cruzamentos não foi coincidente e, mesmo os grupos formados para a população BR-105 não foram totalmente coincidentes para o caráter produção de grãos. Assim, conclui-se que para o caráter altura da planta a separação das linhagens em grupos heteróticos a partir de estimativas de CEC e marcadores RFLP não foi eficiente. Isso ocorre, pelo fato 
desse caráter ser controlado principalmente por genes de efeito aditivo e portanto, apresenta pouca dominância.

\subsubsection{Altura da espiga (AE)}

As estimativas dos efeitos de CEC das linhagens oriundas da população BR-105 à nível intrapopulacional estão na Tabela 16 . $\mathrm{O}$ híbrido $05 \times 07$ apresentou o maior efeito de CEC e altamente significativo, considerando-se então a linhagem 05 para GI e a linhagem 07 para GII. Observando-se os cruzamentos da linhagem 05 com as outras linhagens, somente com a linhagem 02 o efeito da CEC foi positivo, sendo que nos cruzamentos com as linhagens $01,03,04,06$ e 08 as estimativas foram negativas, destacando-se o cruzamento com a linhagem 08 cuja estimativa de CEC foi altamente significativa. No cruzamento da linhagem $07 \mathrm{com}$ as demais, os efeitos positivos foram com a 01,02 , e 08 , indicando que pertencem a GI, sendo que ambas não foram diferentes de zero. Os cruzamentos que mostraram efeitos negativos foram com a 03, 04 e 06 , destacando-se o cruzamento com a linhagem 06 que apresentou um valor negativo de CEC muito acentuado. Baseando-se nas estimativas de CEC (Tabela 16), na análise de agrupamento das linhagens (Figura 13) e na análise de coordenadas principais (Figura 15), foram formados dois grupos heteróticos, onde o GI constituiu-se pelas linhagens 05 e 08 e o GII pelas linhagens 01, 02, 03, 04, 06 e 07.

$\mathrm{Na}$ análise de coordenadas principais verifica-se que as linhagens 05 e 08 estão separadas das demais. As três primeiras coordenadas principais explicaram $54,9 \%$ da variância total. Observando-se os valores médios para os grupos (Tabela 36), nota-se que esses foram similares, sendo um pouco mais baixo para o GI. As estimativas de CEC apresentaram valores negativos para os grupos e positivos para os cruzamentos entre grupos. Os maiores valores de distâncias genéticas foram obtidos para GI e para GIxGII. As correlações entre distâncias genéticas com estimativas de CEC foram significativas somente para GII. Os grupos heteróticos formados baseando-se nas estimativas de CEC discordam dos grupos obtidos por distâncias genéticas (Figuras 30 e 
32), indicando que a alocação das linhagens a partir de estimativas de CEC não foi eficiente para o caráter altura da espiga nessa população.

As estimativas de CEC para as linhagens da população BR-106 avaliadas à nível intrapopulacional não apresentaram valores diferentes de zero (Tabela 21). Observandose o dendograma da análise de agrupamento (Figura 14) e os gráficos da análise de coordenadas principais (Figura 16), percebe-se a formação de quatro grupos heteróticos, sendo GI composto pelas linhagens 09 e 17; GII pelas linhagens 10 e 13; GIII pelas linhagens 11 e 12; e GIV composto pelas linhagens 14, 15 e 18. Observando-se principalmente o gráfico em três dimensões (Figura 16), vê-se a formação dos quatro grupos. As três primeiras coordenadas principais explicaram $55,0 \%$ da variância total. Observando-se os valores médios dos grupos (Tabela 37), verifica-se que as médias dos cruzamentos entre os grupos superaram as médias dos grupos, com exceção do cruzamento GIIIxGIV. As estimativas de CEC foram positivas para os cruzamentos entre grupos e negativas para os grupos, sendo que somente para o GIIxGIV foi negativo. As distâncias genéticas oscilaram entre e dentro dos grupos. A menor distância genética foi observada para o GII, o qual é composto pelas linhagens irmãs 11 e 12. As correlações entre distâncias genéticas com estimativas de CEC foram significativas para os cruzamentos entre todas as linhagens e para o cruzamento GIxGIV. Apesar das correlações positivas, os agrupamentos a partir de estimativas de CEC discordam daqueles obtidos por meio de distâncias genéticas (Figuras 33 e 35), mostrando que a alocação das linhagens a partir das estimativas de CEC não foram eficientes nessa população.

Observando-se as estimativas de CEC das linhagens da população BR-105 em cruzamentos com as linhagens oriundas da população BR-106 (Tabela 26), verifica-se que três híbridos apresentaram estimativas diferentes de zero. Nos híbridos $04 \times 16$ e 08x09 as estimativas foram negativas, e no híbrido $04 \times 14$, a estimativa de CEC foi positiva. Através da análise de agrupamento (Figura 17) e de coordenadas principais (Figura 19) nota-se a formação de três grupos, sendo GI formado pelas linhagens 01, 02, 03, 04, 13 e 18; GII pelas linhagens 06, 07, 11, 12, 14 e 15; e GIII pelas linhagens 05, $08,09,10$ e 17. A visualização dos grupos formados pela análise de coordenadas 
principais foi dificultada devido ao número de linhagens. As três primeiras coordenadas principais explicaram $31,8 \%$ da variância total. As médias dos grupos, dos cruzamentos entre os grupos e de todas as linhagens encontram-se na Tabela 38. A maior média foi observada no GI. Dentre os cruzamentos dos grupos, o GIxGII apresentou a menor média $(106,01 \mathrm{~cm} /$ planta). As estimativas de CEC foram negativas para os grupos e positivas para os cruzamentos entre os grupos. As correlações entre distâncias genéticas com estimativas de CEC foram todas não significativas. Comparando-se os agrupamentos formados a partir de estimativas de CEC com os dados de distâncias genéticas (Figuras 34 e 36), verifica-se uma discordância de resultados. Do mesmo modo que ocorreu para altura da planta, houve uma mistura das linhagens e essas não apresentaram um padrão heterótico definido. Portanto, os marcadores RFLP não foram confiáveis na alocação de linhagens em grupos heteróticos na avaliação à nível interpopulacional. Devido ao pequeno efeito de dominância para o caráter altura da espiga, a utilização de estimativas de CEC para a alocação das linhagens em grupos heteróticos distintos não foi eficiente.

\subsubsection{Posição relativa da espiga (PRE)}

As estimativas dos efeitos de CEC para as linhagens oriundas da população BR105 avaliadas à nível intrapopulacional estão na Tabela 17. O híbrido $02 \times 05$ apresentou o maior efeito de CEC diferente de zero, considerando-se então a linhagem 02 para GI e a linhagem 05 para GII. Observando-se o cruzamento da linhagem 02 com as outras linhagens, as que mostraram efeitos positivos de CEC, foram com as linhagens 03 e 08 , sendo ambas não significativas. As combinações que mostraram efeitos de CEC negativos foram com a $01,04,06$ e 07 , destacando-se o cruzamento com a linhagem 04 com estimativa de CEC diferente de zero. Verificando-se o cruzamento da linhagem 05 com as demais, as que apresentaram efeitos positivos de CEC foram com a 03 e a 07 , destacando-se o cruzamento com a 03 com valor significativo. Os cruzamentos que 
apresentaram valores negativos de CEC foram com a 01, 04, 06 e 08, destacando-se os cruzamentos com as linhagens 06 e 08 com valores significativos.

Baseando-se nas estimativas de CEC (Tabela 17), na análise de agrupamento (Figura 18) e na análise de coordenadas principais (Figura 20) foram formados dois grupos heteróticos. O GI foi formado pelas linhagens 01, 02 e 04 e o GII pelas linhagens 03, 05, 06, 07 e 08. As três primeiras coordenadas principais refletiram 43,3\% da variância total. Os valores médios do caráter posição relativa da espiga sofreram pequena variação entre os grupos, sendo o menor valor observado para o GI. As estimativas de CEC foram negativas para os grupos e positiva para o cruzamento GIxGII. As distâncias genéticas também apresentaram pequena variação e o menor valor também foi observado para GI. As correlações entre distâncias genéticas com estimativas de CEC foram todas não significativas (Tabela 39). Comparando-se esses resultados com os dados obtidos de distâncias genéticas (Figuras 30 e 32), nota-se uma discordância em relação aos grupos heteróticos formados. Assim, a formação de grupos heteróticos por meio de estimativas de CEC não foi eficiente para essa população.

As estimativas dos efeitos de CEC para as linhagens oriundas da população BR106 avaliadas à nível intrapopulacional não apresentaram valores diferentes de zero (Tabela 22). Baseando-se nas estimativas de CEC (Tabela 22), no dendograma (Figura 21) e nos gráficos de coordenadas principais (Figura 23) foram formados dois grupos heteróticos, sendo o GI formado pelas linhagens 11 e 12 e o GII pelas linhagens 09, 10, $13,14,15,17$, e 18. Devido às pequenas diferenças nas estimativas de CEC, a separação das linhagens em grupos heteróticos foi dificultada. Através da análise de coordenadas principais (Figura 23) verifica-se que as linhagens 11 e 12 ficaram separadas das demais, sendo portanto, agrupadas em GI. Observando-se os valores médios da posição relativa da espiga para os grupos, nota-se que não houve variação (Tabela 40). O maior valor para a distância genética foi encontrado para GII e o menor valor para GI. As correlações entre distâncias genéticas com estimativas de CEC foram todas não significativas. Semelhante ao que ocorreu com a população BR-105, os grupos heteróticos formados a partir das estimativas de CEC diferiram dos grupos formados a 
partir de distâncias genéticas (Figuras 33 e 34), indicando que a formação de grupos heteróticos a partir de estimativas de CEC não foi eficiente para essa população.

$\mathrm{Na}$ avaliação das linhagens à nível interpopulacional, observa-se que não houve estimativas de CEC diferentes de zero (Tabela 27). Observando-se o dendograma da análise de agrupamento (Figura 22) e os gráficos da análise de coordenadas principais (Figura 24) visualiza-se a formação de quatro grupos heteróticos, sendo o GI formado pelas linhagens 01, 02, 03 e 18; o GII pelas linhagens 04, 07, 11 e 12; o GIII pelas linhagens 03, 08, 09 e 17; e o GIV pelas linhagens 05, 06, 10, 14 e 15. Os grupos foram formados baseando-se principalmente no dendograma (Figura 22). A visualização dos grupos nos gráficos da análise de coordenadas principais ficou dificultada devido aos pequenos valores das estimativas de CEC. As três primeiras coordenadas principais explicaram apenas $25,3 \%$ da variância total. Os valores médios da posição relativa da espiga para os grupos e para o cruzamento entre os grupos apresentaram pequena variação. As estimativas de CEC foram negativas para os grupos e positivas para os cruzamentos entre grupos, com exceção de GIxGII que apresentou estimativa negativa de CEC. As distâncias genéticas também apresentaram pequena variação. As correlações entre distâncias genéticas com estimativas de CEC foram não significativas. Os agrupamentos obtidos por meio das estimativas de CEC (Figura 22) discordam daqueles obtidos de distâncias genéticas (Figura 34). Novamente verifica-se uma mistura das linhagens e a não formação de padrões heteróticos definidos, mostrando que a formação de grupos heteróticos a partir de estimativas de CEC não foi eficiente na avaliação à nível interpopulacional. Portanto, para o caráter posição relativa da espiga, que também apresenta pequeno efeito de dominância, a alocação das linhagens em grupos heteróticos a partir das estimativas de CEC não foi eficiente.

\subsubsection{Prolificidade (PROL)}

As estimativas dos efeitos de CEC para as linhagens oriundas da população BR105 avaliadas à nível intrapopulacional encontram-se na Tabela 18. O híbrido 05x06 apresentou o maior efeito de CEC diferente de zero, considerando-se a linhagem 05 para 
GI e a linhagem 06 para GII. Observando-se o cruzamento da linhagem 05 com as demais, somente com a linhagem 04 o efeito de CEC foi positivo e com as linhagens 01 , 02, 03, 07 e 08 os valores foram negativos, destacando-se o cruzamento com a linhagem 03 com valor significativo. Verificando-se o cruzamento da linhagem 06 com as demais, as combinações que apresentaram efeitos positivos de CEC foram com a 02 e a 08 e as que apresentaram valores negativos foram com a 01,03, 04 e 07, destacando-se o cruzamento com a linhagem 07 com valor significativo. Baseando-se nas estimativas de CEC (Tabela 18), na análise de agrupamento (Figura 25) e na análise de coordenadas principais (Figura 27), nota-se a formação de dois grupos heteróticos, onde o GI foi formado pelas linhagens $01,02,03,04,05$ e 08 e o GII pelas linhagens 06 e 07 . As três primeiras coordenadas principais explicaram $46,3 \%$ da variância total. Comparando-se os valores médios do caráter prolificidade para os grupos, verifica-se que o cruzamento GIxGII apresentou a maior média (1,108 espigas/planta). Os valores das estimativas de CEC foram negativos para os grupos e positivo para o cruzamento GIxGII, sendo que este último apresentou a maior distância genética. As correlações entre distâncias genéticas com estimativas de CEC foram todas não significativas. Comparando-se esses resultados com os dados de distância genética (Figuras 30 e 32), verifica-se que há uma concordância em relação aos grupos, porém, as relações dentro de GI não são as mesmas (Figura 25). Nota-se então, que os marcadores RFLP foram eficientes na alocação das linhagens em grupos heteróticos para essa população.

Nas linhagens oriundas da população BR-105 avaliadas à nível intrapopulacional, somente o cruzamento das linhagens $09 \times 18$ apresentou-se diferente de zero (Tabela 23). Baseando-se na análise de agrupamento das linhagens (Figura 26) e na análise de coordenadas principais (Figura 28), percebe-se a formação de dois grupos heteróticos, sendo o GI composto pelas linhagens $09,10,13$ e 15 e o GII pelas linhagens $11,12,14,17$ e 18. Devido aos pequenos valores das estimativas de CEC, a visualização dos grupos nos gráficos obtidos a partir das análise de coordenadas principais não ficou muito clara. As três primeiras coordenadas principais explicaram $49,6 \%$ da variância total. Os valores médios da prolificidade variaram de 0,872 espigas/planta (GII) a 1,081 espigas/planta (GI). O grupo II também apresentou a menor distância genética. As 
estimativas de CEC foram negativas para os grupos e positiva para GIxGII. As correlações entre distâncias genéticas com estimativas de CEC foram não significativas (Tabela 43). Comparando-se os grupos formados a partir de CEC (Figura 26) com aqueles formados a partir das distâncias genéticas (Figura 33), nota-se que os grupos foram semelhantes, com exceção da linhagem 15, indicando que os marcadores moleculares foram eficientes na alocação das linhagens em grupos heteróticos para essa população.

Observando-se as estimativas de CEC das linhagens da população BR-105 em cruzamentos com as linhagens oriundas da população BR-106 (Tabela 28), verifica-se que não ocorreram estimativas diferentes de zero. Baseando-se na análise de agrupamento das linhagens (Figura 31) e na análise de coordenadas principais (Figura 30), nota-se a formação de três grupos heteróticos, sendo o GI formado pelas linhagens 01, 03, 05, 08, 09, 10 e 15; o GII pelas linhagens 02, 04, 11, 12, 17 e 18; e o GIII pelas linhagens 06, 07, 13 e 14. Do mesmo modo que ocorreu com o caráter PRE, não foi possível identificar os grupos através dos gráficos das análises de coordenadas principais. As três primeiras coordenadas principais explicaram apenas 20,03\% da variância total. Os valores médios de prolificidade variaram de 0,944 espigas/planta (GII) a 1,061 espigas/planta (GIxGIII). Nota-se que as médias dos cruzamentos entre os grupos foram maiores que as médias dos grupos (Tabela 44). As estimativas de CEC foram negativas para os grupos e positivas para os cruzamentos entre grupos. As maiores distâncias genéticas foram observadas para GI e para o cruzamento GIxGIII. As correlações entre distâncias genéticas com estimativas de CEC foram não significativas. Comparando-se os grupos heteróticos formados, verifica-se que existe uma discordância entre os dados de CEC (Figuras 31 e 30) e de distâncias genéticas (Figura 34 e 36). Ocorreu uma mistura das linhagens das duas populações, evitando com isso, a formação de um padrão heterótico definido, indicando que a alocação das linhagens das populações BR-105 e BR-106 avaliadas à nível interpopulacional a partir de estimativas de CEC não foi eficiente. Portanto, a utilização de marcadores RFLP para alocar as linhagens em grupos heteróticos distintos só foi eficiente nas avaliações à nível intrapopulacional para o caráter prolificidade. 


\subsection{Considerações finais}

Os programas de melhoramento de milho normalmente desenvolvem milhares de novas linhagens endogâmicas anualmente. Assim, é necessário se estabelecer os grupos heteróticos destas linhagens para que os cruzamentos sejam direcionados e tornem o processo mais eficiente, evitando a obtenção e a avaliação de cruzamentos (híbridos) desnecessários. Inicialmente, as linhagens são alocadas nos grupos heteróticos das populações de onde foram obtidas. Uma vez que existe variabilidade genética nestas populações, este padrão heterótico estabelecido pode não ser o mais adequado e, portanto, deve-se avaliar as linhagens para melhorar o estabelecimento de seus padrões heteróticos. Com a separação das linhagens em grupos heteróticos, o número de cruzamentos a serem realizados e avaliados em experimentos com repetições seria reduzido, aumentando assim, a eficiência do programa de melhoramento. Uma das maneiras de separar as linhagens em grupos heteróticos é através de cruzamentos dialélicos, os quais têm se mostrado eficientes (Terron et al. 1997; Gonzalez et al. 1997; Han et al., 1991). Entretanto o uso de cruzamentos dialélicos é restrito a um pequeno número de linhagens devido as dificuldades de se realizar e avaliar todos os cruzamentos possíveis. Uma alternativa para aumentar a eficiência desse processo seria a alocação das linhagens em grupos heteróticos utilizando-se marcadores moleculares.

A maioria dos trabalhos utilizando-se marcadores moleculares para alocar genótipos em grupos heteróticos foi realizada com populações de milho de climas temperados, sendo que estes mostraram que os marcadores do tipo RFLP são úteis para alocar linhagens em grupos heteróticos distintos (Lee et al., 1989; Melchinger et al., 1990a, 1990b, 1991 e 1992; Godshalk et al., 1990; Boppenmaier et al., 1992, 1993; Livini et al., 1992; Smith \& Smith, 1992; Dhillon et al., 1993; Dubreuil et al., 1996). O material temperado tem sido explorado por várias décadas de melhoramento e devido as muitas gerações de seleção, as linhagens usadas nos cruzamentos têm uma estreita base genética e as suas genealogias são bem conhecidas. Assim, a formação de grupos heteróticos a partir de linhagens de milho de clima temperado utilizando-se marcadores moleculares resulta em agrupamentos que são consistentes com a genealogia dessas 
linhagens. As linhagens utilizadas neste trabalho são oriundas das populações de milho tropical BR-105 e BR-106, as quais apresentam heterose de magnitude elevada em cruzamentos (Naspolini $\mathrm{F}^{\mathrm{o}}$ et al., 1981; Souza Jr. et al., 1993), o que significa que pertencem a grupos heteróticos distintos. As populações de milho tropical geralmente são compostos com grande variabilidade genética, o que gera dificuldades na alocação de suas linhagens em grupos heteróticos distintos. Então, além da separação das populações em grupos heteróticos, dentro das populações existe variabilidade suficiente para a formação de novos grupos heteróticos, consequentemente, pode-se dividir as linhagens oriundas da mesma população em grupos heteróticos distintos e melhorar substancialmente a exploração da heterose. Han et al. (1991) e Terron et al. (1997) reportaram que é possível retirar linhagens e formar híbridos intrapopulacionais das populações de milho do CIMMYT, as quais possuem ampla base genética.

Lanza et al. (1997) utilizando-se as mesmas 18 linhagens das populações de milho BR-105 e BR-106 mostraram que as distâncias genéticas baseadas em RAPD poderiam ser usadas para se estabelecer grupos heteróticos entre as linhagens. Foram formados três grupos heteróticos, em que a população BR-106 foi dividida em dois grupos diferentes e a população BR-105 permaneceu como um único grupo. Porém, no presente trabalho, os marcadores do tipo RFLP foram eficientes para separar em grupos heteróticos tanto as linhagens da população BR-106 como as linhagens da população BR-105.

De acordo com o que foi relatado anteriormente, observa-se que o uso de cruzamentos dialélicos tem sido eficiente para detectar divergências genéticas entre linhagens de milho e alocá-las em grupos heteróticos distintos, portanto, nesse trabalho comparou-se a eficiência do uso de marcadores moleculares do tipo RFLP com os cruzamentos dialélicos para alocar as linhagens em grupos heteróticos.

Os grupos heteróticos foram formados a partir das estimativas de capacidade específica de combinação (CEC) utilizando-se de três critérios, ou seja, as linhagens foram separadas em grupos heteróticos baseando-se no maior valor da estimativa de CEC e a partir daí foi feita a separação dos grupos heteróticos; as linhagens foram separadas também utilizando-se análise agrupamento (UPGMA); e, também, através da 
análise de coordenadas principais. Os três critérios foram eficientes na separação das linhagens em grupos hetróticos visto que os seus resultados foram similares. Em geral, as produtividades médias dos híbridos simples intragrupos foram inferiores às produtividades médias dos cruzamentos intergrupos. Os valores médios das estimativas de CEC a produção de grãos foram negativos para os cruzamentos intragrupos e positivos para os cruzamentos intergrupos, indicando que as linhagens dos diferentes grupos combinam melhor do que dentro de cada grupo. Esses resultados mostram que dentro de uma população é possível separar as linhagens em grupos heteróticos e promover cruzamentos específicos para que a heterose seja maximizada. As distâncias genéticas de RFLP mostraram que os grupos cujos híbridos apresentaram as menores produtividades médias foram também os menos divergentes. Livini et al. (1992) e Hahn et al. (1995) reportaram resultados em milho coincidentes com os resultados desta pesquisa.

As análises de agrupamento e de coordenadas principais obtidas a partir das estimativas das capacidades específicas de combinação e das distâncias genéticas obtidas por marcadores moleculares do tipo RFLP foram eficientes na formação dos grupos heteróticos. Separadamente, tanto a análise de coordenadas principais como a análise de agrupamento (dendograma) podem gerar dúvidas na alocação de linhagens aos seus grupos heteróticos. $\mathrm{Na}$ análise de coordenadas principais geralmente são utilizadas as três primeiras coordenadas as quais podem não conter a maior parte da variação, e no dendograma pode-se ter dificuldades de leitura. Assim, utilizando-se em conjunto as duas metodologias as dúvidas podem ser diminuídas e a alocação das linhagens aos seus respectivos grupos heteróticos pode ser feita com menor margem de erro. Portanto, para se obter um resultado mais preciso, seria recomendável a utilização dos dois métodos.

Para o caráter produção de grãos, os grupos heteróticos formados a partir das estimativas de CEC foram coincidentes com aqueles formados a partir das distâncias genéticas obtidas por marcadores RFLP. Para as linhagens da população BR-105 avaliadas à nível intrapopulacional, somente a linhagem 02 comportou-se de modo diferenciado, mostrando que $87,5 \%$ das linhagens foram alocadas no mesmo grupo 
heterótico via estimativas de capacidade específica de combinação e marcadores RFLP. Nas linhagens da população BR-106 avaliadas à nível intrapopulacional, a semelhança nos resultados foi de 94,1\%. Quando as linhagens da população BR-105 foram avaliadas em cruzamentos com as linhagens da população BR-106, essa coincidência foi de $88,2 \%$, mostrando que os marcadores RFLP foram eficientes na alocação das linhagens das populações BR-105 e BR-106 em grupos heteróticos distintos para o caráter produção de grãos. Esses resultados mostraram uma tendência mais favorável para o uso de marcadores RFLP, pois estes separaram as populações BR-105 e BR-106 em dois grupos e depois, separaram as linhagens em grupos heteróticos dentro de cada população.

As linhagens das populações BR-105 e BR-106 foram alocadas em quatro grupos heteróticos distintos, sendo que dois grupos eram formados somente por linhagens da população BR-105 e os outros dois formados por linhagens da população BR-106. Como os grupos formados à nível intra e interpopulacional foram coincidentes, concluiu-se que não seria necessário realizar análises estatísticas à nível intrapopulacional para separar as linhagens em grupos heteróticos. A separação de grupos heteróticos dentro de cada população mostra um refinamento na seleção das linhagens para a formação de híbridos de milho, o que pode ser confirmado observando-se as médias dos híbridos onde verifica-se que alguns híbridos intrapopulacionais produziram tanto quanto outros híbridos interpopulacionais mais produtivos. Observa-se também que alguns híbridos com altas CEC não foram os mais produtivos, porém, com a separação das linhagens em grupos heteróticos aqueles cruzamentos que apresentaram estimativas de CEC negativas e foram pouco produtivos não seriam realizados. Observa-se que dentro das populações existe variabilidade suficiente para a formação de grupos heteróticos.

Para os caracteres altura da planta, altura da espiga e posição relativa da espiga, os agrupamentos com base nas estimativas de CEC não foram coincidentes com os agrupamentos utilizando-se marcadores moleculares. Devido a esses caracteres serem controlados principalmente por genes de efeito aditivo, não foi possível discriminar as linhagens em grupos heteróticos a partir de estimativas de CEC. Para o caráter prolificidade, somente nas avaliações à nível intrapopulacional os agrupamentos a partir 
de estimativas de CEC e distâncias genéticas foram coincidentes. Isto pode ter ocorrido devido a este caráter ser um dos componentes da produção de grãos e a formação dos grupos heteróticos à nível intrapopulacional foi eficiente, porém, à nível interpopulacional ocorreu uma mistura das linhagens das duas populações e não foram formados grupos heteróticos definidos.

Observando-se os grupos formados para o caráter produção de grãos para as linhagens das populações BR-105 e BR-106, verifica-se que o grupo 1 (GI) foi composto por cinco linhagens, o GII por 4 linhagens, o GIII por 3 linhagens e o GIV por 5 linhagens, o que corresponde a aproximadamente $30,0 \%, 20,0 \%, 30,0 \%$ e $20,0 \%$, respectivamente das linhagens avaliadas. Assim, supondo-se um programa de melhoramento em que 1.000 linhagens dessas populações seriam avaliadas com 4 linhagens elites utilizadas como testadoras e se todos os cruzamentos fossem realizados, seriam obtidos 4.000 híbridos simples para serem avaliados em experimentos com repetições em diversos ambientes. Entretanto, separando-se essas 1.000 linhagens em quatro grupos heteróticos utilizando-se as porcentagens citadas acima, seriam formados quatro grupos com 300, 200, 300 e 200 linhagens, respectivamente. Avaliando-se a divergência genética das 4 linhagens elites com os grupos heteróticos formados e considerando-se que apenas uma linhagem elite se cruza bem com cada um dos grupos heteróticos, seriam necessários apenas 1.000 cruzamentos. Portanto, 3.000 cruzamentos e as respectivas avaliações não seriam realizados. Com a utilização dos marcadores moleculares a avaliação da divergência genética das linhagens torna-se mais fácil e consequentemente, um maior número de linhagens poderão ser avaliadas. Separando-se, então, essas linhagens em grupos heteróticos, o número de cruzamentos e de híbridos simples a serem avaliados será menor e, com isso, aumenta-se a eficiência dos programas de melhoramento. Nesse trabalho os marcadores RFLP foram eficientes na alocação das linhagens em grupos heteróticos para o caráter produção de grãos e isto sugere que esses marcadores podem se utilizados na alocação de linhagens de milho em grupos heteróticos. 


\section{CONCLUSÕES}

Com base nos resultados obtidos com este material e nas condições deste trabalho, pode-se concluir que:

- Para o caráter produção de grãos, os grupos heteróticos formados a partir das estimativas de CEC foram similares àqueles obtidos por marcadores moleculares;

- Como os agrupamentos à nível intra e interpopulacional foram coincidentes para o caráter produção de grãos, torna-se desnecessário se fazer análises estatísticas à nivel intrapopulacional;

- Os marcadores RFLP podem ser utilizados para alocar linhagens a grupos heteróticos para o caráter produção de grãos e reduzir o número de cruzamentos e avaliações desses em experimentos com repetições;

- Para o caráter prolificidade, os agrupamentos formados a partir das estimativas de CEC foram eficientes somente nas avaliações à nível intrapopulacional;

- Para os caracteres altura da planta, altura da espiga e posição relativa da espiga, não foi possível discriminar as linhagens e alocá-las em grupos heteróticos a partir de estimativas de CEC. 


\section{REFERÊNCIAS BIBLIOGRÁFICAS}

ALLARD, R. W. Principles of plant breeding. New York, John Wiley \& Sons, p.381, 1960.

ANJMONE-MARSAN, P.; LIVINI, C.; MESSMER, M. M.; MELCHINGER, A. E.; MOTTO, M. Cluster analysis of RFLP data from related maize inbred lines of the BSSS and LSC heterotic groups and comparison with pedigree data. Euphytica, v.60, n.2, p. 139-48, 1992.

ANJMONE MARSAN, P.; CASTIGLIONI, P.; FUSARI, F.; KUIPER, M.; MOTTO, $M$. Genetic diversity and its relationship to hybrid performance in maize as revealed by RFLP and AFLP markers. Theoretical Applied Genetics, v.96, n.2, p.219-27, 1998.

BAKER, R. J. Issues in diallel analysis. Crop Science, v. 18, n.4, p. 533-36, 1978.

BECK, D. L.; VASAL, S. K.; CROSSA, J Heterosis and combining ability among subtropical and temperate intermediate-maturity maize germplasm. Crop Science, v.31, n. 1, p.68-73, 1991.

BOPPENMAIER, J.; MELCHINGER, A. E.; BRUNKLAUS-JUNG, E.; GEIGER, H. H.; HERRMANN, R. G. Genetic diversity for RFLPs in European maize inbreds: 1 . Relation to performance of flint $x$ dent crosses for forage traits. Crop Science, v.32, n.2, p.895-902, 1992.

BOPPENMAIER, J.; MELCHINGER, A. E.;SEITZ, G.; GEIGER, H. H.; HERRMANN, R. G. Genetic diversity for RFLPs in European maize inbreds: Ill. Performance of crosses within versus between heterotic groups for grain traits. Plant Breeding, v.111, n.3, p.217-26, 1993.

BRETTING, P. K.; GOODMAN, M. M.; STUBER, C. W. Isozymatic variation in Guatemalan races of maize. American Journal of Botany, v.77, n.2, p.211-25, 1990. 
BRUNKLAUS-JUNG, E.; LUDWING, W. F.; BOPPENMAIER, J.; MELCHINGER, A. E.; HERRMANN, R. G. RFLP analyses of early maturing European maize germplasm: II. Correlation between RFLP and pedigree data. Maydica, v.38, n.4, p.239-44, 1993.

BURSTIN, J.; VIENNE, D.; DAMERVAL, C. Molecular markers and protein quantities as genetic descriptors in maize. I. Genetic diversity among 21 inbred lines. Theoretical Applied Genetics, v.89, n.7-8, p.943-50, 1994.

BURSTIN, J.; CHARCOSSET, A.; BARRIĖRE, Y.; HEBERT, Y.; VIENNE, D.; DAMERVAL, C. Molecular markers and protein quantities as genetic descriptors in maize. Il. Prediction of performance of hybrids for forage traits. Plant Breeding, v.114, n.5, p.427-33, 1995.

COCHRAN, W. G.; COX, G. M. Experimental designs. Second edition, New York: J. Wiley \& Sons, 1957, 611p.

CROSSA, J.; TABA, S.; WELLHAUSEN, J. Heterotic patterns among mexican races of maize. Crop Science, v.30, n.3, p.1182-90, 1990.

CRUZ, C. D. Aplicações de algumas técnicas multivariadas no melhoramento de plantas. Piracicaba, abril, 1990. 188p. Tese (Doutorado) - Escola Superior de Agricultura "Luiz de Queiroz" - USP.

CRUZ, C. D.; CARVALHO, S. P.; VENCOVSKY, R. Estudos sobre divergência genética. II. eficiência da predição do comportamento de híbridos com base na divergência de progenitores. Revista Ceres, v.41, n.234, p. 183-90, 1994a.

CRUZ, C. D.; VENCOVSKY, R.; CARVALHO, S. P. Estudos sobre divergência genética. IIl. comparação de técnicas multivariadas. Revista Ceres, v.41, n.234, p. 191-201, 1994b.

DAVIS, R. L. Report of the plant breeder. Report "Puerto Rico Agricultural Experimental Station". p. 14-15, 1927.

DHILLON, B. S.; BOPPENMAIER, J.; POLLMER, W. G.; HERRMANN, R. G.; MELCHINGER, A. E. Relationship of restriction fragment length polymorphisms among European maize inbreds with ear dry matter yield of their hybrids. Maydica, v.38, n.4, p.245-48, 1993.

DOEBLEY, J. F.; GOODMAN, M. M.; STUBER, C. W. Isozyme variation in maize from the southwestern United States: taxonomic and anthropological implications. Maydica, v.28, n.2, p.97-120, 1983. 
DOEBLEY, J. F.; GOODMAN, M. M.; STUBER, C. W. Isozyme variation in the races of maize from Mexico. American Journal of Botany, v.72, n. 5, p.629-39, 1985.

DOEBLEY, J. F.; GOODMAN, M. M.; STUBER, C. W. Exceptional genetic divergence of northern flint corn. American Journal of Botany, v.73, n. 1, p.64-69, 1986.

DOEBLEY, J. F.; WENDEL, J. D.; SMITH, J. S. C.; STUBER, C. W.; GOODMAN, M. M. The origin of Cornbelt maize: the isozyme evidence. Economic Botany, v.42, n. 1, p.120-31, 1988.

DUBREUIL, P.; DUFOUR, P.; KREJCI, E.; CAUSSE, M.; VIENNE, D.; GALLAIS, A.; CHARCOSSET, A. Organization of RFLP diversity among inbred lines of maize representing the most significant heterotic groups. Crop Science, v.36, n.3, p. 790-99, 1996.

DUBREUIL, P.; CHARCOSSET, A. Genetic diversity within and among maize populations: a comparison between isozyme and nuclear RFLP loci. Theoretical Applied Genetics, v.96, n.4, p.577-87, 1998.

DUDLEY, J. W.; SAGHAI MAROOF, M. A.; RUFENER, G. K. Molecular markers and grouping of parents in maize breeding programs. Crop Science, v.31, n.2, p.718-23, 1991.

FELSENSTEIN, J. Confidence limits on phylogenies: an approach using the bootstrap. Evolution, v.34, n.4, p.783-91, 1985.

FERREIRA, D. F.; REZENDE, G.D.S.P.; RAMALHO, M. A. P. An adaptation of Griffing's method IV of complete diallel cross analysis for experiments repeated in several environments. Revista Brasileira de Genética, v. 16, n.2, p.357-66, 1993.

FERREIRA, D. F.; OLIVEIRA, A. C.; SANTOS, M. X.; RAMALHO, M. A. P. Métodos de avaliação da divergência genética em milho e suas relações com os cruzamentos dialélicos. Pesquisa Agropecuária Brasileira, v.30, n.9, p.1189-94, 1995.

FERREIRA, M. E.; GRATTAPAGLIA, D. Aplicações de marcadores na genética e melhoramento de plantas. IN: Introdução ao uso de marcadores RAPD e RFLP em análise genética. Brasília: EMBRAPA-CENARGEM, 1995, p.69-118.

FREI, O. M.; STUBER, C. W.; GOODMAN, M. M. Use of allozymes as genetic markers for predicting performance in maize single cross hybrids. Crop Science, v.26, n.1, p.37-42, 1986. 
FUZATTO, S. R. Divergência genética e sua relação com os cruzamentos dialélicos na cultura do milho. Lavras, janeiro, 1999. 65p. Dissertação (Mestrado) - Universidade Federal de Lavras.

GAMA, E. E. G.; HALLAUER, A. R.; FERRÃO, R. G.; BARBOSA, D. M. Heterosis in maize single crosses derived from a yellow Tuxpeño variety in Brazil. Revista Brasileira de Genética, v. 18, n. 1, p.81-85, 1995.

GARDNER, C. O.; EBERHART, S. A. Analysis and interpretation of the variety cross diallel and related populations. Biometrics, v.22, n. 14, p.439-52, 1966.

GERDES, J. T.; TRACY, W. F. Pedigree diversity within the lancaster surecrop heterotic group of maize. Crop Science, v.33, n.1, p.334-37, 1993.

GERDES, J. T.; TRACY, W. F. Diversity of historically important sweet corn inbreds as determined by RFLPs, morphology, isozymes, and pedigrees. Crop Science, v.34, n. 1, p.26-33, 1994.

GERRISH, E. E. Indication from a diallel study for interracial maize hybridization in the Corn Belt. Crop Science, v.23, n. 6, p. 1082-84, 1983.

GODSHALK, E. B.; LEE, M.; LAMKEY, K. R. Relationship of restriction fragment length polymorfisms to single-cross hybrid performance of maize. Theoretical Applied Genetics, v.80, n.2, p.273-80, 1990.

GONELLA, J. A.; PETERSON, P. A. Isozyme relatedness of inbred lines of maize and performance of their hybrids Maydica, v.23, n.2, p.55-61, 1978.

GONZALEZ, S.; CÓRDOVA, H.; RODRIGUEZ, S.; DE LEON, H.; SERRATO, V. M. Determinacion de un patron heterotico a partir de la evaluacion de un dialelo de diez lineas de maiz subtropical. Agronomia Mesoamericana, v.8, n. 1, p.01-07, 1997.

GOODMAN, M. M. Exotic maize germplasm: Status, prospects, and remedies. Iowa State Journal Reseacrh, v.59, p.497-527, 1985.

GOODMAN, M. M.; STUBER, C. W. Races of maize. Vl. Isozyme variation among races of maize in Bolivia. Maydica, v.28, n.2, p. 169-87, 1983.

GRIFFING, B. Concept of general and specific combining ability in relation to diallel crossing systems. Australian Journal of Biological Science, v.9, p.463-93, 1956.

HAHN, V.; BLANKENHORN, K.; SCHWALL, M.; MELCHINGER, A. E. Relationships among early European maize inbreds: 111. Genetic diversity revealed with RAPD markers and comparison with RFLP and pedigree data. Maydica, v.40, n. 4, p.299-310, 1995. 
HALLAUER, A. R.; MIRANDA FILHO, J. B. Quantitative genetics in maize breeding. Iowa State University Press, p.468, 1981.

HALLAUER, A. R.; RUSSELL, W. A.; LAMKEY,K. R. Corn breeding In: Corn and corn improvment, 3rd. Edition, G. F. Sprague \& J. W. Dudley (eds.), Madison, p.453-64, 1988.

HALLAUER, A. R. Methods using in developing maize inbreds. Maydica, v.35, n.1, p.1-16, 1990.

HAN, G. C.; VASAL, S. K.; BECK, D. L.; ELIAS, E. Combining ability of inbred lines derived from CIMMYT maize (Zea mays L.) germplasm. Maydica, v.36, n. 1, p.5764,1991

HAYMAN, B. I. The analysis of variance of diallel tables. Biometrics, v.10, n.1, p.235-44, 1954a.

HAYMAN, B. I. The theory and analysis of diallel crosses. Genetics, v.39, p.789-809, $1954 b$.

HEIDRICH-SOBRINHO, E.; CORDEIRO, A. R. Codominant isoenzymic alleles as markers of genetic diversity correlated with heterosis in maize (Zea mays). Theoretical Applied Genetics, v.46, n.4, p. 197-99, 1975.

HOISINGTON, D.; KHAIRALLAH, M.; GONZALEZ-DE-LEON, D. Laboratory protocols: CIMMYT applied molecular genetics laboratory. Second edition, Mexico DF: CIMMYT, 1994.

HUNTER, R. B.; KANNENBERG, L. W. Isozyme characterization of corn (Zea mays) inbreds and its relationship to single cross hybrid performance. Canadian Journal of Genetics and Cytology, v. 13, n.4, p.649-55, 1971.

JENKINS, M. T.; BRUNSON, A. M. Methods of testing inbred lines of maize in crossbred combinations. Journal of American Society of Agronomy, v.24, p.523$30,1932$.

KEMPTHORNE, O.; CURNOW, R. N. The partial diallel cross. Biometrics, v. 17, p.229-50, 1961.

LAMKEY, K. R.; HALLAUER, A. R.; KAHLER, A. L. Allelic differences at enzyme loci and hybrid performance in maize. The Journal of Heredity, v.78, n.4, p.231$34,1987$. 
LANZA, L. L. B.; SOUZA Jr., C. L.; OTTOBONI, L. M. M.; VIEIRA, M. L. C.; SOUZA, A. P. Genetic distance of inbred lines and prediction of maize single-cross performance using RAPD markers. Theoretical Applied Genetics, v.94, n.8, p. 1023-30, 1997.

LEE, M.; GODSHALK, E. B.; LAMKEY, K. R.; WOODMAN, W. W. Association of restriction fragment length polymorphisms among maize inbreds with agronomic performance of their crosses. Crop Science, v.29, n.4, p. 1067-71, 1989.

LIVINI, C.; ANJMONE-MARSAN, P.; MELCHINGER, A. E.; MESSMER, M. M.; MOTTO, M. Genetic diversity of maize inbred lines within and among heterotic groups revealed by RFLPs. Theoretical Applied Genetics, v.84, n.1-2, p.17-25, 1992.

LLAURADÓ, M. ; MORENO-GONZALEZ, J. Classification of northern spanish populations of maize by methods of numerical taxonomy. 1. morphological traits. Maydica, v.38, n.1, p. 15-21, 1993.

LLAURADÓ, M.; MORENO-GONZALEZ, J.; ARÚS, P. Classification of northern Spanish populations of maize by methods of numerical taxonomy. II. Isozyme variation. Maydica, v.38, n.4, p.249-58, 1993.

MANLY, B.F. J. Multivariate statistical methods. Second edition, Thomson Press Ltda, New Delhi, Índia, 1994, 215p.

MELCHINGER, A. E.; LEE, M.; LAMKEY, K. R.; WOODMAN, W. L. Genetic diversity for restriction fragment length polymorphisms: relation to estimated genetic effects in maize inbreds. Crop Science, v.30, n.3, p.1033-40, 1990a.

MELCHINGER, A. E.; LEE, M.; LAMKEY, K. R.; HALLAUER, A. R.; WOODMAN, W. L. Genetic diversity for restriction fragment length polymorphisms and heterosis for two diallel sets of maize inbreds. Theoretical Applied Genetics, v.80, n. 4, p. 488-96, $1990 b$.

MELCHINGER, A. E.; MESSMER, M. M.; LEE, M.; WOODMAN, W. L.; LAMKEY, K. R. Diversity and relationships among U.S. maize inbreds revealed by restriction fragment length polymorfisms. Crop Science, v.31, n.2, p.669-78, 1991.

MElChINGER, A. E.; BOPPENMAIER, J.; DHILlON, B. S.; POLLMER, W. G.; HERRMANN, R. G. Genetic diversity for RFLPs in European maize inbreds: II. Relation to performance of hybrids within versus between heterotic groups for forage traits. Theoretical Applied Genetics, v.84, n. 5-6, p.672-81, 1992. 
MESSMER, M. M.; MELCHINGER, A. E.; LEE, M.; WOODMAN, W. L.; LEE, E. A.; LAMKEY, K. R. Genetic diversity among progenitors and elite lines from the lowa Stiff Stalk Synthetic (BSSS) maize population: comparison of allozyme and RFLP data. Theoretical Applied Genetics, v.83, n. 1, p.97-107, 1991.

MESSMER, M. M.; MELCHINGER, A. E.; BOPPENMAIER, J.; BRUNKLAUSJUNG, E.; HERRMANN, R. G. Relationships among early European maize inbreds: 1 . Genetic diversity among flint and dent lines revealed by RFLPs. Crop Science, v.32, n.6, p.1301-09, 1992.

MESSMER, M. M.; MELCHINGER, A. E.; HERRMANN, R. G.; BOPPENMAIER, J.; Relationships among early European maize inbreds: Il. Comparison of pedigree and RFLP data. Crop Science, v.33, n.3, p.944-50, 1993.

MICHELINI, L. A.; HALLAUER, A. R. Evaluation of exotic and adapted maize (Zea mays L.) germplasm crosses. Maydica, v.38, n.4, p.275-82, 1993.

MISEVIC, D. Heterotic patterns among U.S. corn belt, yugoslavian, and exotic maize populations. Maydica, v.34, n.4, p.353-63, 1989.

MOLL, R. H.; SALHUANA, W. S.; ROBINSON, H. F. Heterosis and genetic diversity in variety crosses of maize. Crop Science, v.2, n.3, p.197-98, 1962.

MOLL, R. H.; LONNQUIST, J.; FORTUNA, J. V.; JOHNSON, E. C. The relation of heterosis and genetic divergence in maize. Genetics, v.52, n. 1, p.139-44, 1965.

MUNGOMA, C.; POLLAK, L. M. Heterotic patterns among ten corn belt and exotic maize populations. Crop Science, v.28, n.3, p.500-04, 1988.

NASPOLINI FILHO, V.; GAMA, E. E. G.; VIANNA, R. T.; MÔRO, J. R. General and specific combining ability for yield in a diallel cross among 18 maize populations (Zea mays L.). Revista Brasileira de Genética, v.4, n.4, p.571-77, 1981.

NASS, L. L.; MIRANDA FILHO, J. B.; COSTA, F. M. P. Parâmetros genéticos em quatro compostos de milho. In: Congresso Nacional de Milho e Sorgo, 23, 2000, Uberlândia, MG. A inovação tecnológica e a competitividade no contexto dos mercados globalizados: Resumos. Sete Lagoas: ABMS/Embrapa Milho e Sorgo/Universidade Federal de Uberlândia, 2000. p.68.

PATERNIANI, E.; LONNQUIST, J. H. Heterosis in interracial crosses of corn (Zea mays L.). Crop Science, v.3, n.6, p.504-07, 1963.

PÉREZ-VELÁSQUEZ, J. C.; CEBALLOS, H.; PANDEY, S.; DÍAZ-AMARIS, C. Analysis of diallel crosses among colombian landraces and improved populations of maize. Crop Science, v.35, n.2, p.572-78, 1995. 
POLLAK, L. M.; TORRES-CORDONA, S.; SOTOMAYOR-RIOS, A. Evaluation of heterotic patterns among caribbean and tropical $\mathrm{x}$ temperate maize populations. Crop Science, v.31, n.3, p.1480-83, 1991.

PRICE, S. C.; KAHLER, A. L.; HALlAUER, A. R.; CHARMLEY, P.; GIEGEL, D. A. Relationships between performance and multilocus heterozygosity at enzyme loci in single-cross hybrids of maize. The Journal of Heredity, v.77, n. 5, p.341-44, 1986.

RADOVIC, G.; JELOVAC, D. Identification of the heterotic pattern in Yugoslav maize germplasm. Maydica, v.40, n.3, p.223-27, 1995.

REVILLA, P.; TRACY, W. F. Morphological characterization and classification of open-pollinated sweet corn cultivars. Journal of American Society Horticultural Science, v.120, n. 1, p.112-18, 1995a.

REVILLA, P.; TRACY, W. F. Isozyme variation and phylogenetic relationships among open-pollinated sweet corn cultivars. Crop Science, v.35, n. 1, p.219-27, 1995 b.

REVILLA, P.; TRACY, W. F. Heterotic patterns among open-pollinated sweet corn cultivars. Journal of American Society Horticultural Science, v. 122, n.3, p.31924, 1997.

REVILla, P.; SOENGAS, P.; MAlvaR, R. A.; CARTEA, M.E; ORDÁS, A. lsozyme variation and historical relationships among the maize races of Spain. Maydica, v.43, n.3, p. 175-82, 1998.

ROHLF, F. J. NTSYS-pc numerical taxonimy and multivariate analysis system, version 2.0. Exeter publications, New York, 1997.

SAN VICENTE, F. M.; BEJARANO, A.; MARTIN, C.; CROSSA, J. Analysis of diallel crosses among improved tropical white endosperm maize populations. Maydica, v.43, n.2, p.147-53, 1998.

SHULL, G. F. A pure line method of corn breeding. American Breeders Association Report, v.5, p.51-59, 1909.

SINOBAS, J; MONTEAGUDO, I. Heterotic patterns among U. S. corn belt and spanish maize populations. Maydica, v.42, n.2, p.143-48, 1996.

SMITH, O. S. Covariance between line per se and testcross performance. Crop Science, v.26, n. 1, p.540-43, 1986. 
SMITH, J. S. C.; SMITH, O. S. Association among inbred lines of maize using electrophoretic, chromatographic, and pedigree data. I. Multivariate and cluster analysis of data from "Lancaster Sure Crop" derived lines. Theoretical Applied Genetics, v.73, n.5, p.654-64, 1987.

SMITH, O. S.; SMITH, J. S. C. Measurement of genetic diversity among maize hybrids; a comparison of isozymic, RFLP, pedigree, and heterosis data. Maydica, v.37, n. 1, p. 53-60, 1992.

SMITH, O. S.; SMITH, J. S. C.; BOWEN, S. L.; TENBORG, R. A.; WALL, S. J. Similarities among a group of elite maize inbreds as measured by pedigree. $F_{1}$ grain yield, grain yeld, heterosis, and RFLPs. Theoretical Applied Genetics, v80, n.6, p.833-40, 1990.

SNEATH, P. H. A.; SOKAL, R. R. Numerical taxonomy. San Francisco: W. H. Freeman and Company, 1973. 573p.

SOUZA Jr., C. L.; SANTOS, M. X.; MAGNAVACA, R.; GAMA, E. E. G. Estimativas de parâmetros genéticos na interpopulação de milho BR-105 x BR-106 e suas implicações no melhoramento. Pesquisa Agropecuária Brasileira, v.28, n.4, p.473-79, 1993.

SPANER, D.; BRATHWAITE, R. A. I.; MATHER, D. E. Diallel study of openpollinated maize varieties in Trinidad. Euphytica, v.90, n.1, p.65-72, 1996.

SPRAGUE, G. F.; TATUM, L. A. General vs specific combining ability in single crosses on corn. Journal of American Society of Agronomy, v.34, n. 10, p.923-32, 1942.

STEEL, R. G. D.; TORRIE,J H. Principles and procedures of statistics. New York: Mc Graw-Hill, 1960. 481 p.

TERRON, A.; PRECIADO, E.; CÓRDOVA, H.; MICKELSON, H.; LÓPEZ, R. Determinacion del patron heterotico de 30 lineas de maiz derivadas de la poblacion 43SR del CIMMYT. Agronomia Mesoamericana, v.8, n.1, p.26-34, 1997.

TRACY, W. F. Potencial of field corn germplasm for the improvement of sweet corn. Crop Science, v.30, p. 104 1-45, 1990.

VASAL, S. K.; SRINVASAN, G.; CROSSA, J.; BECK, D. L. Heterosis and combining ability of CIMMYT's subtropical and temperate early-maturity maize germplasm. Crop Science, v.32, n.2, p.884-90, 1992a. 
VASAL, S. K.; SRINVASAN, G.; GONZÁlEZ, C. F.; HAN, G. C.; PANDEY, S.; BECK, D. L.; CROSSA, J. Heterosis and combining ability of CIMMYT's tropical $x$ subtropical maize germplasm. Crop Science, v.32, n.3, p.1483-89, 1992 b.

VASAL, S. K.; SRINVASAN, G.; PANDEY, S.; CORDOVA, H. S.; HAN, G. C.; GONZALEZ, C. F. Heterotic patterns of ninety-two white tropical CIMMYT maize lines. Maydica, v.37, n.3, p.259-70, 1992c.

VASAL, S. K.; SRINVASAN, G.; HAN, G. C.; GONZALEZ, C. F. Heterotic patterns of eighty-eight white subtropical CIMMYT maize lines. Maydica, v.37, n.4, p.319$27,1992 d$.

VASAL, S. K.; SRINVASAN, G.; PANDEY, S.; GONZÁLEZ, C. F.; CROSSA, J.; BECK, L. Heterosis and combining ability of CIMMYT's quality protein maize germplasm: 1. Jowland tropical. Crop Science, v.33, n.1, p.46-51, 1993a.

VASAL, S. K.; SRINVASAN, G.; PANDEY, S.; GONZÁLEZ, C. F.; CROSSA, J.; BECK, L. Heterosis and combining ability of CIMMYT's quality protein maize germplasm: II. subtropical. Crop Science, v.33, n. 1, p.51-57, 1993 b.

VENCOVSKY, R. Análise de cruzamentos dialélicos entre variedades pelo método de Gardner e Eberhart. Relatório Científico I de Genética. Piracicaba, n.3, p.99$111,1969$.

VENCOVSKY, R. Alguns aspectos teóricos e aplicados relativos a cruzamentos dialélicos de variedades. Piracicaba, 1970. 59p. Tese (Livre-Docência) - Escola Superior de Agricultura "Luiz de Queiroz" - USP.

VENCOVSKY, R. Herança Quantitativa. In: Paterniani, E. \& Viegas, G. P., ed. Melhoramento e produção do milho. 2. ed., Campinas, Fundação Cargill, 1987. V.1, p.135-214.

VENCOVSKY, R; BARRIGA, P. Genética biométrica no fitomelhoramento Ribeirão Preto, SP: Sociedade Brasileira de Genética, p.486, 1992.

VOS, P.; HOGERS, R.; BLEEKER, M.; REIJANS, M.; Van DE LEE, T.; HORMES, M.; FRIJTERS, A.; POT, J.; POLEMAN, J.; KUIPER, M.; ZABEAU, M. AFLP: a new technique for DNA fingerprinting. Nucleic Acids Research, v.23, n.21, p.4407-414, 1995.

WELSH, J.; McCELLAND, M. Fingerprinting genomes using PCR with arbitrarily primers. Nucleic Acids Research, v. 18, n.24, p.7213-18, 1990. 
TABELAS 
Tabela 6. Valores e significâncias dos quadrados médios das análises conjuntas de variâncias, para os híbridos intrapopulacionais, para os caracteres produção de grãos (PG), altura da planta (AP), altura da espiga (AE), posição relativa da espiga (PRE) e prolificidade (PROL).

\begin{tabular}{|c|c|c|c|c|c|c|c|}
\hline \multirow[b]{2}{*}{ F. V. } & \multirow[b]{2}{*}{ G.L. } & \multicolumn{4}{|c|}{ Q.M. } & \multirow[b]{2}{*}{ G.L. } & \multirow{2}{*}{$\begin{array}{c}\text { Q.M. } \\
\text { PROL }^{+} \\
\text {(esp./pl.) }\end{array}$} \\
\hline & & $\begin{array}{l}\text { PG } \\
\text { (t/ha) }\end{array}$ & $\begin{array}{c}\text { AP } \\
\text { (cm/planta) }\end{array}$ & $\begin{array}{c}\mathrm{AE} \\
(\mathrm{cm} / \text { planta) }\end{array}$ & $\mathrm{PRE}^{+}$ & & \\
\hline Ambientes (A) & 1 & $2,28^{*}$ & $36251,04^{* *}$ & $19977,95^{* *}$ & $419,83^{* *}$ & 2 & $55,49 * *$ \\
\hline Repetições/A & 4 & 1,56 & 120,85 & 115,53 & 20,27 & 6 & 2,98 \\
\hline Tratamentos $(\mathrm{T})$ & 80 & $3,68^{* *}$ & $153,98^{* *}$ & $105,49 * *$ & $5,62 * *$ & 80 & $4,02^{\text {ns }}$ \\
\hline $\mathrm{T} \times \mathrm{A}$ & 80 & $0,41^{* *}$ & $70,04^{* *}$ & $45,63^{* *}$ & $3,40^{* *}$ & 160 & $1,32^{* *}$ \\
\hline Erro efetivo médio & 270 & 0,23 & 58,78 & 33,94 & 2,35 & 408 & 1,08 \\
\hline Média & & 6,44 & 207,54 & 107,82 & 0,52 & & 1,42 \\
\hline $\mathrm{CV} \%$ & & 10,04 & 4,03 & 6,27 & 3,56 & & 18,45 \\
\hline
\end{tabular}

${ }^{* *} \mathrm{P} \leq 0,01 ;{ }^{*} \mathrm{P} \leq 0,05 ;{ }^{\mathrm{ns}} \mathrm{P} \geq 0,05$

${ }^{+}$Q.M. x $10^{4} ;{ }^{*}$ Q.M. $\times 10^{-2}$

Tabela 7. Valores e significâncias dos quadrados médios das análises conjuntas de variâncias, para os híbridos interpopulacionais, para os caracteres produção de grãos (PG), altura da planta (AP), altura da espiga (AE), posição relativa da espiga (PRE) e prolificidade (PROL).

\begin{tabular}{lcccccc}
\hline & & \multicolumn{5}{c}{ Q.M. } \\
\cline { 3 - 7 } F. V. & G.L. & $\begin{array}{c}\text { PG } \\
(\mathrm{t} / \mathrm{ha})\end{array}$ & $\begin{array}{c}\text { AP } \\
(\mathrm{cm} / \text { planta })\end{array}$ & $\begin{array}{c}\text { AE } \\
(\mathrm{cm} / \text { planta })\end{array}$ & PRE $^{+}$ & $\begin{array}{c}\text { PROL }^{*} \\
\text { (esp./pl.) }\end{array}$ \\
Ambientes (A) & 5 & $40,44^{* *}$ & $32033,02^{* *}$ & $28306,67^{* *}$ & $1920,74^{* *}$ & $160,50^{* *}-$ \\
Repetições/A & 6 & 0,25 & 6602,70 & 562,87 & 415,07 & 5,22 \\
Tratamentos (T) & 99 & $0,52^{* *}$ & $530,50^{* *}$ & $270,35^{* *}$ & $14,77^{* *}$ & $3,57^{* *}$ \\
T x A & 495 & $0,10^{* *}$ & $69,00^{* *}$ & $44,07^{* *}$ & $4,47^{* *}$ & $1,23^{* *}$ \\
Erro efetivo médio & 486 & 0,06 & 53,44 & 30,37 & 0,28 & 0,98 \\
\hline Média & & 7,37 & 205,94 & 105,56 & 0,51 & 0,98 \\
CV\% & & 11,82 & 4,03 & 6,29 & 4,14 & 11,30 \\
\hline
\end{tabular}

${ }^{*} * \mathrm{P} \leq 0,01 ;{ }^{*} \mathrm{P} \leq 0,05 ;{ }^{\mathrm{n} s} \mathrm{P} \geq 0,05$

${ }^{+}$Q.M. x $10^{-4}$; ${ }^{*}$ Q.M. x $10^{-2}$ 
Tabela 8. Valores e significâncias dos quadrados médios das análises conjuntas de variâncias para capacidade geral de combinação (CGC) e capacidade específica de combinação (CEC) para os caracteres produção de grãos (PG), altura da planta (AP), altura da espiga ( $\mathrm{AE})$, posição relativa da espiga (PRE) e prolificidade (PROL), relativas às linhagens da população BR-105 avaliadas em cruzamentos intrapopulacionais.

\begin{tabular}{|c|c|c|c|c|c|c|c|}
\hline \multirow[b]{2}{*}{ F. V. } & \multicolumn{5}{|c|}{ Q.M. } & \multirow[b]{2}{*}{ G.L. } & \multirow{2}{*}{$\begin{array}{l}\text { Q.M. } \\
\text { PROL }^{\alpha} \\
\text { (esp./pl.) }\end{array}$} \\
\hline & G.L. & $\begin{array}{l}\mathrm{PG}^{\#} \\
(\mathrm{t} / \mathrm{ha})\end{array}$ & $\begin{array}{c}\text { AP } \\
(\mathrm{cm} / \text { planta })\end{array}$ & $\begin{array}{c}\mathrm{AE} \\
(\mathrm{cm} / \text { planta) }\end{array}$ & $\mathrm{PRE}^{+}$ & & \\
\hline Ambientes (A) & 1 & 2,16 & 11661,65 & 5735,58 & 7,83 & 2 & 14,44 \\
\hline C.G.C. & 7 & $21,75^{* *}$ & $425,13^{* *}$ & $347,96^{* *}$ & $1,39^{* *}$ & 7 & $4,13^{* *}$ \\
\hline C.E.C. & 20 & $12,33^{* *}$ & $138,94^{\mathrm{ns}}$ & $85,89^{\text {ns }}$ & $0,39^{\mathrm{ns}}$ & 20 & $2,93^{\text {ns }}$ \\
\hline C.G.C. x A & 7 & $1,05^{\text {ns }}$ & $29,55^{\mathrm{ns}}$ & $46,45^{\mathrm{ns}}$ & $0,42^{\mathrm{ns}}$ & 14 & $0,93^{\text {ns }}$ \\
\hline C.E.C. $\times$ A & 20 & $4,04^{* *}$ & $73,48^{\text {ns }}$ & $43,11^{\mathrm{ns}}$ & $0,33^{\text {ns }}$ & 40 & $1,50^{\text {ns }}$ \\
\hline Erro médio & 270 & 2,34 & 58,78 & 33,94 & 0,23 & 408 & 1,08 \\
\hline
\end{tabular}

**P $\leq 0,01 ;{ }^{*} \mathrm{P} \leq 0,05 ;{ }^{\mathrm{n} P} \mathrm{P} \geq 0,05$

${ }^{\#}$ Q.M. x $10^{-1} ;{ }^{+}$Q.M. $\times 10^{-3} ;{ }^{+}$Q.M. $\times 10^{-2}$

Tabela 9. Valores e significâncias dos quadrados médios das análises conjuntas de variâncias para capacidade geral de combinação (CGC) e capacidade específica de combinação (CEC) para os caracteres produção de grãos (PG), altura da planta (AP), altura da espiga $(\mathrm{AE})$, posição relativa da espiga $(\mathrm{PRE})$ e prolificidade $(\mathrm{PROL})$, relativas às linhagens da população BR-106 avaliadas em cruzamentos intrapopulacionais.

\begin{tabular}{lccccccc} 
& & \multicolumn{3}{c}{ Q.M. } & & Q.M. \\
\cline { 3 - 8 } F. V. & G.L. & $\begin{array}{c}\text { PG } \\
(\mathrm{t} / \mathrm{ha})\end{array}$ & $\begin{array}{c}\text { AP } \\
(\mathrm{cm} / \text { planta })\end{array}$ & $\begin{array}{c}\text { AE } \\
(\mathrm{cm} / \text { planta })\end{array}$ & PRE $^{+}$ & G.L. & $\begin{array}{c}\text { PROL } \\
\text { (esp. } / \mathrm{pl} .\end{array}$ \\
\hline Ambientes (A) & 1 & 7,06 & 18457,81 & 11250,52 & 305,60 & 2 & 37,83 \\
C.G.C. & 9 & $13,1^{* *}$ & $263,29^{*}$ & $178,19^{* *}$ & $9,66^{*}$ & 9 & $11,04^{* *}$ \\
C.E.C. & 30 & $1,67^{* *}$ & $79,07^{\text {ns }}$ & $49,98^{\text {ns }}$ & $3,37^{\text {ns }}$ & 30 & $1,59^{\text {ns }}$ \\
C.G.C. $x$ A & 9 & $0,22^{\text {ns }}$ & $89,60^{\text {ns }}$ & $47,68^{\text {ns }}$ & $4,87^{\text {ns }}$ & 18 & $2,52^{\text {ns }}$ \\
C.E.C. $x$ A & 30 & $0,27^{\text {ns }}$ & $95,03^{\text {ns }}$ & $52,15^{\text {ns }}$ & $3,28^{\text {ns }}$ & 60 & $1,48^{\text {ns }}$ \\
Erro médio & 270 & 0,23 & 58,78 & 33,94 & 2,35 & 408 & 1,08 \\
\hline
\end{tabular}

${ }^{*} * \mathrm{P} \leq 0,01 ; * \mathrm{P} \leq 0,05 ;{ }^{\mathrm{ns}} \mathrm{P} \geq 0,05$

${ }^{+}$Q.M. x $10^{-4} ;{ }^{*}$ Q.M. $\times 10^{-2}$ 
Tabela 10. Valores e significâncias dos quadrados médios das análises conjuntas de variâncias para capacidade geral de combinação (CGC) e capacidade específica de combinação (CEC) para os caracteres produção de grãos (PG), altura da planta (AP), altura da espiga $(\mathrm{AE})$, posição relativa da espiga (PRE) e prolificidade $(\mathrm{PROL})$, relativas às linhagens das populações BR-105 e BR-106 avaliadas em cruzamentos interpopulacionais.

\begin{tabular}{lrccccc}
\hline & & \multicolumn{5}{c}{ Q.M. } \\
\cline { 3 - 7 } F. V. & G.L. & $\begin{array}{c}\text { PG } \\
(\mathrm{t} / \mathrm{ha})\end{array}$ & $\begin{array}{c}\text { AP } \\
(\mathrm{cm} / \text { planta })\end{array}$ & $\begin{array}{c}\text { AE } \\
(\mathrm{cm} / \text { planta })\end{array}$ & PRE $^{+}$ & $\begin{array}{c}\text { PROL }^{*} \\
\text { (esp./pl. })\end{array}$ \\
\hline Ambientes (A) & 5 & 32,54 & 25113,52 & 22233,40 & 146,45 & 120,43 \\
C.G.C.1 (BR-106) & 9 & $1,55^{* *}$ & $1246,59^{* *}$ & $704,85^{* *}$ & $4,38^{* *}$ & $9,73^{* *}$ \\
C.G.C.2 (BR-105) & 7 & $1,03^{* *}$ & $3506,81^{* *}$ & $1419,34^{* *}$ & $5,81^{* *}$ & $6,76^{* *}$ \\
C.E.C. & 63 & $0,23^{* *}$ & $187,69^{* *}$ & $112,30^{* *}$ & $0,63^{* *}$ & $2,15^{* *}$ \\
C.G.C.1 x A & 45 & $0,17^{* *}$ & $122,60^{* *}$ & $85,62^{* *}$ & $0,84^{* *}$ & $2,00^{* *}$ \\
C.G.C.2 x A & 35 & $0,13^{* *}$ & $154,23^{* *}$ & $78,01^{* *}$ & $0,94^{* *}$ & $1,77^{* *}$ \\
C.E.C. x A & 315 & $0,09^{* *}$ & $51,79^{\text {ns }}$ & $33,55^{\text {ns }}$ & $0,31^{\text {ns }}$ & $0,98^{\text {ns }}$ \\
Erro médio & 486 & 0,06 & 53,44 & 30,37 & 0,28 & 0,98 \\
\hline
\end{tabular}

${ }^{* * P} \leq 0,01 ;{ }^{*} \mathrm{P} \leq 0,05 ;{ }^{\text {ns }} \mathrm{P} \geq 0,05$

${ }^{+}$Q.M. x $10^{-3} ;{ }^{+}$Q.M. $\times 10^{-2}$ 
Tabela 11. Estimativas dos efeitos da capacidade geral de combinação( $\left.\hat{\mathrm{g}}_{\mathrm{i}}\right)$ e desvio padrão (D.P.) do contraste de duas linhagens, para os caracteres produção de grãos (PG), altura da planta (AP), altura da espiga (AE), posição relativa da espiga (PRE) e prolificidade (PROL), relativas às linhagens da população BR-105 avaliadas em cruzamentos dialélicos intrapopulacionais.

\begin{tabular}{cccccc}
\hline Linhagens & $\begin{array}{c}\text { PG } \\
(\mathrm{t} / \mathrm{ha})\end{array}$ & $\begin{array}{c}\mathrm{AP} \\
(\mathrm{cm} / \mathrm{planta})\end{array}$ & $\begin{array}{c}\mathrm{AE} \\
(\mathrm{cm} / \mathrm{planta})\end{array}$ & PRE & $\begin{array}{c}\text { PROL } \\
\text { (esp./pl. })\end{array}$ \\
\hline $\mathbf{0 1}$ & $0,553^{* *}$ & 1,531 & $-0,298$ & $-0,005$ & $0,073^{* *}$ \\
$\mathbf{0 2}$ & $-0,337^{* *}$ & 3,018 & 2,755 & 0,005 & 0,023 \\
$\mathbf{0 3}$ & $-0,357^{* *}$ & $-7,913^{* *}$ & $-5,875^{* *}$ & $-0,007$ & $-0,041$ \\
$\mathbf{0 4}$ & 0,137 & $-2,669$ & $-3,079$ & $-0,006$ & $-0,047$ \\
$\mathbf{0 5}$ & $0,619^{* *}$ & $6,550^{* *}$ & $7,868^{* *}$ & $0,019^{* *}$ & 0,034 \\
$\mathbf{0 6}$ & 0,019 & $-0,882$ & $-0,788$ & $-0,003$ & 0,013 \\
$\mathbf{0 7}$ & $-0,076$ & $8,026^{* *}$ & $6,363^{* *}$ & $0,010^{*}$ & 0,013 \\
$\mathbf{0 8}$ & $-0,558^{* *}$ & $-7,661^{* *}$ & $-6,947^{* *}$ & $-0,013^{* *}$ & $-0,069$ \\
\hline D.P. $\left(\hat{g}_{\mathrm{i}}-\hat{\mathrm{g}}_{\mathrm{j}}\right)$ & 0,197 & 3,130 & 2,378 & 0,006 & 0,042 \\
\hline \hline
\end{tabular}

Significativo a $* 5 \% \mathrm{e}^{* *} 1 \%$ de probabilidade, pelo teste $\mathrm{t}$. 
Tabela 12. Estimativas dos efeitos da capacidade geral de combinação $\left(\hat{\mathrm{g}}_{\mathrm{i}}\right)$ e desvio padrão (D.P.) do contraste de duas linhagens, para os caracteres produção de grãos (PG), altura da planta (AP), altura da espiga (AE), posição relativa da espiga (PRE) e prolificidade (PROL), relativas às linhagens da população BR-106 avaliadas em cruzamentos dialélicos intrapopulacionais.

\begin{tabular}{cccccc}
\hline Linhagens & $\begin{array}{c}\mathrm{PG} \\
(\mathrm{t} / \mathrm{ha})\end{array}$ & $\begin{array}{c}\text { AP } \\
(\mathrm{cm} / \text { planta })\end{array}$ & $\begin{array}{c}\text { AE } \\
\text { (cm/planta) }\end{array}$ & PRE & $\begin{array}{c}\text { PROL } \\
\text { (esp./pl. })\end{array}$ \\
\hline $\mathbf{0 9}$ & $0,767^{* *}$ & 3,313 & 3,823 & 0,009 & 0,031 \\
$\mathbf{1 0}$ & $0,333^{*}$ & 1,121 & 1,975 & 0,006 & 0,032 \\
$\mathbf{1 1}$ & $-0,750^{* *}$ & $-3,641$ & $-3,125$ & $-0,006$ & $-0,048$ \\
$\mathbf{1 2}$ & $-1,176^{* *}$ & $-0,679$ & $-0,192$ & 0,002 & $-0,024$ \\
$\mathbf{1 3}$ & $1,304^{* *}$ & 0,323 & 1,220 & 0,005 & $0,164^{* *}$ \\
$\mathbf{1 4}$ & $-0,649^{* *}$ & $-4,682$ & $-3,379$ & $-0,004$ & $-0,076$ \\
$\mathbf{1 5}$ & $0,609^{* *}$ & $6,239^{*}$ & 2,518 & $-0,003$ & $-0,033$ \\
$\mathbf{1 6}$ & $1,945^{* *}$ & $8,382^{* *}$ & $7,335^{* *}$ & $0,014^{* *}$ & 0,080 \\
$\mathbf{1 7}$ & $-1,075^{* *}$ & $-7,318^{* *}$ & $-5,317^{* *}$ & $-0,007$ & $-0,076$ \\
$\mathbf{1 8}$ & $-1,307^{* *}$ & $-3,058$ & $-4,858^{*}$ & $-0,016^{* *}$ & $-0,050$ \\
\hline D.P. $\left(\hat{\mathrm{g}}_{\mathrm{i}}-\hat{\mathrm{g}}_{\mathrm{j}}\right)$ & 0,247 & 3,833 & 2,913 & 0,007 & 0,090 \\
\hline
\end{tabular}

Significativo a $* 5 \% \mathrm{e}^{* *} 1 \%$ de probabilidade, pelo teste $\mathrm{t}$. 
Tabela 13. Estimativas dos efeitos da capacidade geral de combinação $\left(\hat{\mathrm{g}}_{\mathrm{i}}\right)$ e desvio padrão (D.P.) do contraste de duas linhagens, para os caracteres produção de grãos (PG), altura da planta (AP), altura da espiga (AE), posição relativa da espiga (PRE) e prolificidade (PROL), relativas às linhagens das populações BR-105 e BR-106 avaliadas em cruzamentos dialélicos interpopulacionais.

\begin{tabular}{|c|c|c|c|c|c|c|}
\hline \multicolumn{2}{|c|}{ Linhagens } & $\begin{array}{c}\text { PG } \\
\text { (t/ha) }\end{array}$ & $\begin{array}{c}\text { AP } \\
(\mathrm{cm} / \text { planta })\end{array}$ & $\begin{array}{c}\mathrm{AE} \\
(\mathrm{cm} / \text { planta) }\end{array}$ & PRE & $\begin{array}{c}\text { PROL } \\
\text { (esp./pl.) }\end{array}$ \\
\hline \multirow{8}{*}{ BR-105 } & 01 & $-0,007$ & 1,128 & 0,570 & 0,001 & $0,032 * *$ \\
\hline & 02 & $-0,039$ & $-0,879$ & $1,623^{*}$ & $0,010^{* *}$ & $0,048^{* *}$ \\
\hline & 03 & $-0,207 * *$ & $-10,451 * *$ & $-4,874 * *$ & 0,002 & $-0,052 * *$ \\
\hline & 04 & $-0,096^{* *}$ & $-4,912 * *$ & $-3,135^{* *}$ & $-0,003$ & $-0,021$ \\
\hline & 05 & $0,155^{* *}$ & $7,514 * *$ & $7,335^{* *}$ & $0,017 * *$ & 0,000 \\
\hline & 06 & $0,137^{* *}$ & $8,559^{* *}$ & $2,241 * *$ & $-0,010^{* *}$ & 0,014 \\
\hline & 07 & $0,135^{* *}$ & $7,993 * *$ & $3,739 * *$ & $-0,002$ & 0,012 \\
\hline & 08 & $-0,079 * *$ & $-8,952 * *$ & $-7,500 * *$ & $-0,014 * *$ & $-0,033 * *$ \\
\hline \multirow{10}{*}{ BR-106 } & 09 & $-0,075^{*}$ & $7,919^{* *}$ & $5,537 * *$ & $0,007 * *$ & $0,050 * *$ \\
\hline & 10 & $-0,173 * *$ & $-3,151^{* *}$ & $-3,350^{* *}$ & $-0,009^{* *}$ & $-0,016$ \\
\hline & 11 & $0,165 * *$ & 0,164 & $1,375^{*}$ & $0,007 * *$ & $-0,006$ \\
\hline & 12 & $0,105^{* *}$ & $-1,034$ & 0,117 & 0,002 & 0,006 \\
\hline & 13 & $0,161^{* *}$ & $4,655^{* *}$ & $3,871^{* *}$ & $0,008^{* *}$ & $0,098 * *$ \\
\hline & 14 & 0,031 & $-5,023 * *$ & $-3,983 * *$ & $-0,006^{*}$ & $-0,031^{*}$ \\
\hline & 15 & $0,170^{* *}$ & $2,459^{*}$ & $-2,817^{* *}$ & $-0,020 * *$ & $-0,055^{* *}$ \\
\hline & 16 & $-0,402 * *$ & $5,956 * *$ & $5,422 * *$ & $0,011 * *$ & $-0,042 * *$ \\
\hline & 17 & 0,010 & $-6,310^{* *}$ & $-3,841^{* *}$ & $-0,003$ & $-0,010$ \\
\hline & 18 & 0,008 & $-5,636 * *$ & $-2,331^{* *}$ & 0,004 & 0,007 \\
\hline \multicolumn{2}{|c|}{ D.P.1 $\left(\hat{\mathrm{g}}_{\mathrm{j}_{\mathrm{j}}}-\hat{\mathrm{g}}_{\mathrm{j}^{\prime}}\right)$} & 0,046 & 1,334 & 1,006 & 0,003 & 0,018 \\
\hline \multicolumn{2}{|c|}{ D.P.2 $\left(\hat{\mathrm{g}}_{\mathrm{i}}-\hat{\mathrm{g}}_{\mathrm{i}^{\prime}}\right)$} & 0,052 & 1,492 & 1,125 & 0,003 & 0,020 \\
\hline
\end{tabular}

Significativo a * $5 \% \mathrm{e}^{* *} 1 \%$ de probabilidade, pelo teste $\mathrm{t}$.

D.P.1 e D.P. 2 são os desvios-padrão do contraste entre as linhagens da BR-105 e BR106 , respectivamente. 
Tabela 14. Médias dos híbridos intrapopulacionais (BR-105) para o caráter produção de grãos (t/ha) (acima da diagonal) e estimativas da capacidade específica de combinação (abaixo da diagonal).

\begin{tabular}{ccccccccc}
\hline Linhagens & $\mathbf{0 1}$ & $\mathbf{0 2}$ & $\mathbf{0 3}$ & $\mathbf{0 4}$ & $\mathbf{0 5}$ & $\mathbf{0 6}$ & $\mathbf{0 7}$ & $\mathbf{0 8}$ \\
\hline $\mathbf{0 1}$ & & 6,982 & 6,650 & 6,719 & 7,752 & 7,149 & 8,262 & 6,077 \\
$\mathbf{0 2}$ & 0,156 & & 6,353 & 6,764 & 7,081 & 5,791 & 5,793 & 5,485 \\
$\mathbf{0 3}$ & $-0,156$ & 0,437 & & 6,397 & 6,342 & 7,160 & 6,652 & 4,574 \\
$\mathbf{0 4}$ & $-0,582^{*}$ & 0,354 & 0,007 & & 7,055 & 7,062 & 6,998 & 6,103 \\
$\mathbf{0 5}$ & $-0,031$ & 0,188 & $-0,531$ & $-0,313$ & & 7,631 & 7,207 & 6,923 \\
$\mathbf{0 6}$ & $-0,034$ & $-0,501$ & $0,887^{* *}$ & 0,294 & 0,382 & & 4,371 & $\mathbf{7 , 2 2 6}$ \\
$\mathbf{0 7}$ & $1,175^{* *}$ & $-0,404$ & 0,475 & 0,326 & 0,054 & $-2,183^{* *}$ & & 6,533 \\
$\mathbf{0 8}$ & $-0,528$ & $-0,230$ & $-1,120^{* *}$ & $-0,086$ & 0,252 & $1,154^{* *}$ & 0,558 & \\
\hline
\end{tabular}

D.P. 1: 0,441

D.P.2: 0,395

Significativo a $* 5 \%$ e $* * 1 \%$ de probabilidade, pelo teste $t$.

D.P. $1=\sqrt{v\left(\hat{s}_{i j}-\hat{s}_{i k}\right)} ;$ D.P. $2=\sqrt{v\left(\hat{s}_{i j}-\hat{s}_{k m}\right)}$.

Tabela 15. Médias dos hibridos intrapopulacionais (BR-105) para o caráter altura da planta (cm/planta) (acima da diagonal) e estimativas da capacidade específica de combinação (abaixo da diagonal).

\begin{tabular}{ccccccccc}
\hline Linhagens & $\mathbf{0 1}$ & $\mathbf{0 2}$ & $\mathbf{0 3}$ & $\mathbf{0 4}$ & $\mathbf{0 5}$ & $\mathbf{0 6}$ & $\mathbf{0 7}$ & $\mathbf{0 8}$ \\
\hline $\mathbf{0 1}$ & & 208,345 & 204,922 & 209,123 & 209,684 & 219,433 & 219,745 & 208,028 \\
$\mathbf{0 2}$ & $-6,218$ & & 202,039 & 206,244 & 230,718 & 215,678 & 223,540 & 201,641 \\
$\mathbf{0 3}$ & 1,291 & $-3,079$ & & 205,697 & 200,388 & 195,551 & 210,709 & 203,305 \\
$\mathbf{0 4}$ & 0,247 & $-4,119$ & 6,266 & & 216,338 & 207,860 & 211,160 & 197,660 \\
$\mathbf{0 5}$ & $-8,411$ & $11,136^{*}$ & $-8,262$ & 2,444 & & 218,184 & 239,890 & 194,193 \\
$\mathbf{0 6}$ & 8,771 & 3,529 & $-5,666$ & 1,398 & 2,503 & & 200,998 & 207,094 \\
$\mathbf{0 7}$ & 0,175 & 2,482 & 0,583 & $-4,211$ & $15,300^{* *}$ & $-16,159^{* *}$ & & 212,209 \\
$\mathbf{0 8}$ & 4,145 & $-3,730$ & 8,866 & $-2,024$ & $-14,710^{* *}$ & 5,624 & 1,830 & \\
\hline $\mathbf{D}$
\end{tabular}

D.P. $1: 6,999$

D.P. 2: 6,260

Significativo a $* 5 \%$ e ${ }^{* *} 1 \%$ de probabilidade, pelo teste $\mathrm{t}$.

D.P. $1=\sqrt{v\left(\hat{s}_{i j}-\hat{s}_{i k}\right)} ;$ D.P. $2=\sqrt{v\left(\hat{s}_{i j}-\bar{s}_{k m}\right)}$ 
Tabela 16. Médias dos híbridos intrapopulacionais (BR-105) para o caráter altura da espiga (cm/planta) (acima da diagonal) e estimativas da capacidade específica de combinação (abaixo da diagonal).

\begin{tabular}{cccccccccc}
\hline Linhagens & $\mathbf{0 1}$ & $\mathbf{0 2}$ & $\mathbf{0 3}$ & $\mathbf{0 4}$ & $\mathbf{0 5}$ & $\mathbf{0 6}$ & $\mathbf{0 7}$ & $\mathbf{0 8}$ \\
\hline $\mathbf{0 1}$ & & 107,371 & 103,691 & 106,944 & 111,467 & 116,383 & 118,146 & 106,099 \\
$\mathbf{0 2}$ & $-5,357$ & & 105,483 & 104,554 & 132,510 & 112,641 & 119,747 & 106,115 \\
$\mathbf{0 3}$ & $-0,405$ & $-1,667$ & & 104,937 & 110,719 & 102,034 & 109,578 & 100,192 \\
$\mathbf{0 4}$ & 0,051 & $-5,392$ & 3,622 & & 113,290 & 110,569 & 110,787 & 102,331 \\
$\mathbf{0 5}$ & $-6,373$ & $11,616^{* *}$ & $-1,543$ & $-1,769$ & & 116,282 & 136,845 & 97,984 \\
$\mathbf{0 6}$ & $7,199^{*}$ & 0,403 & $-1,572$ & 4,167 & $-1,068$ & & 103,368 & 105,883 \\
$\mathbf{0 7}$ & 1,811 & 0,358 & $-1,180$ & $-2,767$ & $12,343^{* *}$ & $-12,477^{* *}$ & & 111,598 \\
$\mathbf{0 8}$ & 3,074 & 0,038 & 2,746 & 2,088 & $-13,206 * *$ & 3,348 & 1,912 & \\
\hline
\end{tabular}

D.P. $1: 5,318$

D.P. 2: 4,757

Significativo a $* 5 \%$ e $* * 1 \%$ de probabilidade, pelo teste $t$.

D.P.1 $=\sqrt{v\left(\hat{s}_{i j}-\hat{s}_{i k}\right)} ;$ D.P. $2=\sqrt{v\left(\hat{s}_{i j}-\hat{s}_{k m}\right)}$.

Tabela 17. Médias dos híbridos intrapopulacionais (BR-105) para o caráter posição relativa da espiga (acima da diagonal) e estimativas da capacidade específica de combinação (abaixo da diagonal).

\begin{tabular}{ccccccccc}
\hline Linhagens & $\mathbf{0 1}$ & $\mathbf{0 2}$ & $\mathbf{0 3}$ & $\mathbf{0 4}$ & $\mathbf{0 5}$ & $\mathbf{0 6}$ & $\mathbf{0 7}$ & $\mathbf{0 8}$ \\
\hline $\mathbf{0 1}$ & & 0,515 & 0,502 & 0,512 & 0,529 & 0,527 & 0,536 & 0,509 \\
$\mathbf{0 2}$ & $-0,008$ & & 0,522 & 0,505 & 0,571 & 0,519 & 0,534 & 0,527 \\
$\mathbf{0 3}$ & $-0,009$ & 0,001 & & 0,510 & 0,551 & $\mathbf{0 , 5 1 9}$ & 0,521 & 0,490 \\
$\mathbf{0 4}$ & 0,001 & $-0,017^{*}$ & 0,001 & & 0,522 & 0,531 & 0,523 & 0,517 \\
$\mathbf{0 5}$ & $-0,009$ & $\mathbf{0 , 0 2 3 ^ { * * }}$ & $0,017^{*}$ & $-0,014$ & & 0,527 & 0,569 & 0,506 \\
$\mathbf{0 6}$ & 0,012 & $-0,007$ & 0,007 & $0,018^{*}$ & $-0,125^{* *}$ & & 0,512 & 0,507 \\
$\mathbf{0 7}$ & 0,009 & $-0,005$ & $-0,004$ & $-0,003$ & 0,017 & $-0,018^{*}$ & & 0,523 \\
$\mathbf{0 8}$ & 0,005 & 0,012 & $-0,012$ & 0,014 & $-0,023^{* *}$ & 0,001 & 0,004 & \\
\hline
\end{tabular}

D.P.1: 0,013

D.P.2: 0,011

Significativo a $* 5 \%$ e $* * 1 \%$ de probabilidade, pelo teste $\mathrm{t}$.

D.P.1 $=\sqrt{v\left(\hat{s}_{i j}-\hat{s}_{i k}\right)} ;$ D.P. $2=\sqrt{v\left(\hat{s}_{i j}-\hat{s}_{k m}\right)}$. 
Tabela 18. Médias dos híbridos intrapopulacionais (BR-105) para o caráter prolificidade (espiga/planta) (acima da diagonal) e estimativas da capacidade específica de combinação (abaixo da diagonal).

\begin{tabular}{ccccccccc}
\hline Linhagens & $\mathbf{0 1}$ & $\mathbf{0 2}$ & $\mathbf{0 3}$ & $\mathbf{0 4}$ & $\mathbf{0 5}$ & $\mathbf{0 6}$ & $\mathbf{0 7}$ & $\mathbf{0 8}$ \\
\hline $\mathbf{0 1}$ & & 1,267 & 1,053 & 1,204 & 1,114 & 1,055 & 1,231 & 0,994 \\
$\mathbf{0 2}$ & 0,103 & & 1,115 & 0,949 & 1,115 & 1,201 & 1,036 & 0,936 \\
$\mathbf{0 3}$ & $-0,048$ & $-0,037$ & & 0,943 & 0,976 & 0,984 & 1,154 & 1,009 \\
$\mathbf{0 4}$ & 0,110 & $-0,096$ & $-0,037$ & & 1,056 & 1,009 & 1,081 & 0,953 \\
$\mathbf{0 5}$ & $-0,062$ & $-0,011$ & $-0,862^{* *}$ & 0,001 & & 1,303 & 1,098 & 1,024 \\
$\mathbf{0 6}$ & $-0,101$ & 0,096 & $-0,057$ & $-0,026$ & $0,186^{* *}$ & & 0,910 & 1,102 \\
$\mathbf{0 7}$ & 0,077 & $-0,069$ & 0,114 & 0,047 & $-0,018$ & $-0,187^{* *}$ & & 1,048 \\
$\mathbf{0 8}$ & $-0,078$ & $-0,087$ & 0,050 & 0,000 & $-0,010$ & 0,089 & 0,036 & \\
\hline
\end{tabular}

D.P.1: 0,095

D.P.2: 0,085

Significativo a $* 5 \% \mathrm{e}^{* *} 1 \%$ de probabilidade, pelo teste $\mathrm{t}$.

D.P. $1=\sqrt{v\left(\hat{s}_{i j}-\hat{s}_{i k}\right)} ;$ D.P. $2=\sqrt{v\left(\hat{s}_{i j}-\hat{s}_{k m}\right)}$.

Tabela 19. Médias dos híbridos intrapopulacionais (BR-106) para o caráter produção de grãos (t/ha) (acima da diagonal) e estimativas da capacidade específica de (abaixo da diagonal).

\begin{tabular}{cccccccccccc}
\hline Linhagens & $\mathbf{0 9}$ & $\mathbf{1 0}$ & $\mathbf{1 1}$ & $\mathbf{1 2}$ & $\mathbf{1 3}$ & $\mathbf{1 4}$ & $\mathbf{1 5}$ & $\mathbf{1 6}$ & $\mathbf{1 7}$ & $\mathbf{1 8}$ \\
\hline $\mathbf{0 9}$ & & 5,655 & $\mathbf{7 , 4 6 2}$ & 6,552 & 6,866 & 7,090 & 7,845 & - & 5,956 & $\mathbf{7 , 7 4 9}$ \\
$\mathbf{1 0}$ & $-1,914^{* *}$ & & 6,940 & 5,370 & 8,099 & 6,185 & 6,822 & - & 6,566 & 6,499 \\
$\mathbf{1 1}$ & $0,976^{*}$ & $0,889^{*}$ & & 1,493 & 7,078 & 4,219 & 6,591 & 7,991 & 3,865 & 3,526 \\
$\mathbf{1 2}$ & 0,492 & $-0,256$ & $\mathbf{0 , 0 0 0}$ & & 7,258 & 3,706 & 6,089 & 7,241 & 4,251 & 3,802 \\
$\mathbf{1 3}$ & $-1,674^{* *}$ & $-0,007$ & 0,055 & 0,661 & & 7,683 & 7,218 & - & 7,777 & 6,955 \\
$\mathbf{1 4}$ & 0,503 & 0,032 & $-0,850^{*}$ & $-0,938^{*}$ & 0,559 & & $\mathbf{7 , 1 8 6}$ & $\mathbf{8 , 4 5 1}$ & 4,049 & 4,457 \\
$\mathbf{1 5}$ & 0,000 & $-0,589$ & 0,264 & 0,187 & $-1,164^{* *} 0,757$ & & - & 6,590 & 5,728 \\
$\mathbf{1 6}$ & - & - & 0,328 & 0,003 & - & 0,686 & - & - & 7,473 & 5,955 \\
$\mathbf{1 7}$ & $-0,204$ & $0,840^{*}$ & $-0,778$ & 0,033 & $1,080^{* *-0,695}$ & 0,588 & 0,135 & & 3,087 \\
$\mathbf{1 8}$ & $1,821^{* *}$ & $1,005^{*}$ & $-0,885^{*}$ & $-0,183$ & 0,490 & $-0,055$ & $-0,043$ & $-1,151^{* *}$ & $-0,999^{*}$ & \\
\hline
\end{tabular}

D.P.1: 0,639

D.P. 2: 0,592

Significativo a $* 5 \% \mathrm{e}^{* *} 1 \%$ de probabilidade, pelo teste $\mathrm{t}$.

D.P. $1=\sqrt{v\left(\hat{s}_{i j}-\hat{s}_{i k}\right)} ;$ D.P.2 $=\sqrt{v\left(\hat{s}_{i j}-\hat{s}_{k m}\right)}$. 
Tabela 20. Médias dos híbridos intrapopulacionais (BR-106) para o caráter altura da planta ( $\mathrm{cm} /$ planta) (acima da diagonal) e estimativas da capacidade específica de combinação (abaixo da diagonal).

\begin{tabular}{ccccccccccc}
\hline Linhagens & $\mathbf{0 9}$ & $\mathbf{1 0}$ & $\mathbf{1 1}$ & $\mathbf{1 2}$ & $\mathbf{1 3}$ & $\mathbf{1 4}$ & $\mathbf{1 5}$ & $\mathbf{1 6}$ & $\mathbf{1 7}$ & $\mathbf{1 8}$ \\
\hline $\mathbf{0 9}$ & & 208,560 & 207,675 & 208,700 & 211,814 & 210,607 & 219,286 & - & 198,428 & 210,560 \\
$\mathbf{1 0}$ & $-3,477$ & & 205,717 & 213,571 & 197,721 & 209,938 & 210,134 & - & 204,711 & 209,936 \\
$\mathbf{1 1}$ & 0,401 & 0,635 & & 197,754 & 199,385 & 189,755 & 223,771 & 211,570 & 192,771 & 205,370 \\
$\mathbf{1 2}$ & $-1,536$ & 5,526 & 0,000 & & 216,188 & 194,702 & 214,390 & 209,146 & 201,421 & 201,590 \\
$\mathbf{1 3}$ & 0,575 & $-11,326$ & $-4,900$ & 8,941 & & 205,296 & 211,408 & - & 205,825 & 207,069 \\
$\mathbf{1 4}$ & 4,373 & 5,896 & $-9,525$ & $-7,540$ & 2,052 & & 201,616 & 225,234 & 197,977 & 195,846 \\
$\mathbf{1 5}$ & 2,131 & $-4,829$ & $13,569^{*}$ & 1,227 & $-2,758$ & $-7,544$ & & - & 206,899 & 208,612 \\
$\mathbf{1 6}$ & - & - & $-0,773$ & $-6,159$ & - & $13,931^{*}$ & - & & 205,735 & 208,859 \\
$\mathbf{1 7}$ & $-5,170$ & 3,305 & $-3,873$ & 1,816 & 5,217 & 2,374 & 0,375 & $-2,932$ & & 196,114 \\
$\mathbf{1 8}$ & 2,703 & $\mathbf{4}, 271$ & 4,467 & $-2,275$ & 2,201 & $-4,017$ & $-2,172$ & $-4,067$ & $-1,112$ & \\
\hline
\end{tabular}

D.P. $1: 10,142$

D.P. 2: 9,390

Significativo a $* 5 \% \mathrm{e}^{* *} 1 \%$ de probabilidade, pelo teste $\mathrm{t}$.

D.P. $1=\sqrt{v\left(\hat{s}_{i j}-\hat{s}_{i k}\right)} ;$ D.P. $2=\sqrt{v\left(\hat{s}_{i j}-\hat{s}_{k m}\right)}$.

Tabela 21. Médias dos híbridos intrapopulacionais (BR-106) para o caráter altura da espiga ( $\mathrm{cm} /$ planta) (acima da diagonal) e estimativas da capacidade específica de combinação (abaixo da diagonal).

\begin{tabular}{cccccccccccc}
\hline Linhagens & $\mathbf{0 9}$ & $\mathbf{1 0}$ & $\mathbf{1 1}$ & $\mathbf{1 2}$ & $\mathbf{1 3}$ & $\mathbf{1 4}$ & $\mathbf{1 5}$ & $\mathbf{1 6}$ & $\mathbf{1 7}$ & $\mathbf{1 8}$ \\
\hline $\mathbf{0 9}$ & & 114,720 & 111,336 & 108,773 & 112,491 & 107,862 & 119,230 & - & 101,130 & 106,288 \\
$\mathbf{1 0}$ & 1,113 & & 103,308 & 112,902 & 104,313 & 111,286 & 110,268 & - & 105,183 & 106,986 \\
$\mathbf{1 1}$ & 2,829 & $-3,351$ & & 101,027 & 99,029 & 94,035 & 117,049 & 114,054 & 97,465 & 104,513 \\
$\mathbf{1 2}$ & $-2,667$ & 3,309 & 0,000 & & 117,239 & 101,504 & 108,587 & 110,413 & 105,859 & 98,977 \\
$\mathbf{1 3}$ & $-0,361$ & $-6,691$ & $-6,875$ & 8,402 & & 109,074 & 109,596 & - & 108,040 & 103,895 \\
$\mathbf{1 4}$ & $-0,390$ & 4,881 & $-7,270$ & $-2,734$ & 3,425 & & 99,454 & 120,385 & 102,691 & 96,956 \\
$\mathbf{1 5}$ & 5,149 & $-2,035$ & 9,846 & $-1,548$ & $-1,951$ & $-7,494$ & & - & 104,177 & 104,337 \\
$\mathbf{1 6}$ & - & - & 2,035 & $-4,539$ & - & 8,619 & - & & 103,867 & 110,132 \\
$\mathbf{1 7}$ & $-5,186$ & 0,715 & $-1,902$ & 3,559 & 4,328 & 3,578 & $-0,834$ & $-5,961$ & & 99,336 \\
$\mathbf{1 8}$ & $-0,487$ & 2,059 & 4,687 & $-3,782$ & $-0,276$ & $-2,616$ & $-1,133$ & $-0,154$ & 1,702 \\
\hline
\end{tabular}

D.P. $1: 7,707$

D.P. 2: 7,135

D.P.1 $=\sqrt{v\left(\hat{s}_{i j}-\hat{s}_{i k}\right)} ;$ D.P.2 $=\sqrt{v\left(\hat{s}_{i j}-\hat{s}_{k m}\right)}$. 
Tabela 22. Médias dos híbridos intrapopulacionais (BR-106) para o caráter posição relativa da espiga (acima da diagonal) e estimativas da capacidade específica de combinação (abaixo da diagonal).

\begin{tabular}{ccccccccccc}
\hline Linhagens & $\mathbf{0 9}$ & $\mathbf{1 0}$ & $\mathbf{1 1}$ & $\mathbf{1 2}$ & $\mathbf{1 3}$ & $\mathbf{1 4}$ & $\mathbf{1 5}$ & $\mathbf{1 6}$ & $\mathbf{1 7}$ & $\mathbf{1 8}$ \\
\hline $\mathbf{0 9}$ & & 0,545 & 0,532 & 0,521 & 0,530 & 0,509 & 0,541 & - & 0,503 & 0,503 \\
$\mathbf{1 0}$ & 0,013 & & 0,501 & 0,528 & 0,523 & 0,528 & 0,522 & - & 0,510 & 0,504 \\
$\mathbf{1 1}$ & 0,012 & $-0,016$ & & 0,508 & 0,495 & 0,495 & 0,523 & 0,535 & 0,505 & 0,503 \\
$\mathbf{1 2}$ & $-0,008$ & 0,003 & 0,000 & & 0,542 & 0,520 & 0,503 & 0,525 & 0,527 & 0,490 \\
$\mathbf{1 3}$ & $-0,001$ & $-0,005$ & $-0,021$ & 0,018 & & 0,530 & 0,518 & - & 0,520 & 0,498 \\
$\mathbf{1 4}$ & $-0,012$ & 0,009 & 0,012 & $-0,005$ & 0,012 & & 0,488 & 0,534 & 0,518 & 0,493 \\
$\mathbf{1 5}$ & 0,019 & 0,003 & 0,015 & $-0,013$ & $-0,001$ & $-0,021$ & & - & 0,500 & 0,501 \\
$\mathbf{1 6}$ & - & - & 0,010 & $-0,008$ & - & 0,007 & - & & 0,504 & 0,524 \\
$\mathbf{1 7}$ & $-0,016$ & $-0,005$ & 0,001 & 0,016 & 0,006 & 0,013 & $-0,006$ & $-0,019$ & & 0,503 \\
$\mathbf{1 8}$ & $-0,007$ & $-0,003$ & 0,009 & $-0,013$ & $-0,007$ & $-0,003$ & 0,004 & 0,009 & 0,010 & \\
\hline
\end{tabular}

D.P.1: 0,020

D.P.2: 0,018

D.P. $1=\sqrt{v\left(\hat{s}_{i j}-\hat{s}_{i k}\right)} ;$ D.P. $2=\sqrt{v\left(\hat{s}_{i j}-\hat{s}_{k m}\right)}$.

Tabela 23. Médias dos híbridos intrapopulacionais (BR-106) para o caráter prolificidade (espigas/planta) (acima da diagonal) e estimativas da capacidade específica de combinação (abaixo da diagonal).

\begin{tabular}{ccccccccccc}
\hline Linhagens & $\mathbf{0 9}$ & $\mathbf{1 0}$ & $\mathbf{1 1}$ & $\mathbf{1 2}$ & $\mathbf{1 3}$ & $\mathbf{1 4}$ & $\mathbf{1 5}$ & $\mathbf{1 6}$ & $\mathbf{1 7}$ & $\mathbf{1 8}$ \\
\hline $\mathbf{0 9}$ & & 1,038 & 1,011 & 1,008 & 1,147 & 1,039 & 1,025 & - & 0,954 & 1,229 \\
$\mathbf{1 0}$ & $-0,065$ & & 1,065 & 1,139 & 1,242 & 1,006 & 0,938 & - & 1,006 & 1,028 \\
$\mathbf{1 1}$ & $-0,011$ & 0,041 & & 0,723 & 1,226 & 0,829 & 1,016 & 1,047 & 0,921 & 0,887 \\
$\mathbf{1 2}$ & $-0,038$ & 0,091 & 0,000 & & 1,169 & 0,866 & 1,024 & 1,091 & 0,882 & 1,014 \\
$\mathbf{1 3}$ & $-0,088$ & 0,005 & 0,070 & $-0,010$ & & 1,141 & 1,098 & - & 1,245 & 1,116 \\
$\mathbf{1 4}$ & 0,044 & 0,010 & $-0,086$ & $-0,073$ & 0,013 & & 0,987 & 1,081 & 0,871 & 0,927 \\
$\mathbf{1 5}$ & $-0,011$ & $-0,100$ & 0,058 & 0,043 & $-0,072$ & 0,057 & & - & 0,981 & 0,929 \\
$\mathbf{1 6}$ & - & - & $-0,025$ & $-0,004$ & - & 0,037 & - & & 1,087 & 1,018 \\
$\mathbf{1 7}$ & $-0,041$ & 0,010 & 0,006 & $-0,057$ & 0,117 & $-0,016$ & 0,051 & 0,043 & & 0,800 \\
$\mathbf{1 8}$ & $0,209^{*}$ & 0,007 & $-0,053$ & 0,049 & $-0,037$ & 0,014 & $-0,026$ & $-0,051$ & $-0,113$ & \\
\hline
\end{tabular}

D.P. $1: 0,168$

D.P.2: 0,155

Significativo a $* 5 \% \mathrm{e}^{* *} 1 \%$ de probabilidade, pelo teste $\mathrm{t}$.

D.P.1 $=\sqrt{v\left(\hat{s}_{i j}-\hat{s}_{i k}\right)} ;$ D.P. $2=\sqrt{v\left(\hat{s}_{i j}-\hat{s}_{k m}\right)}$. 


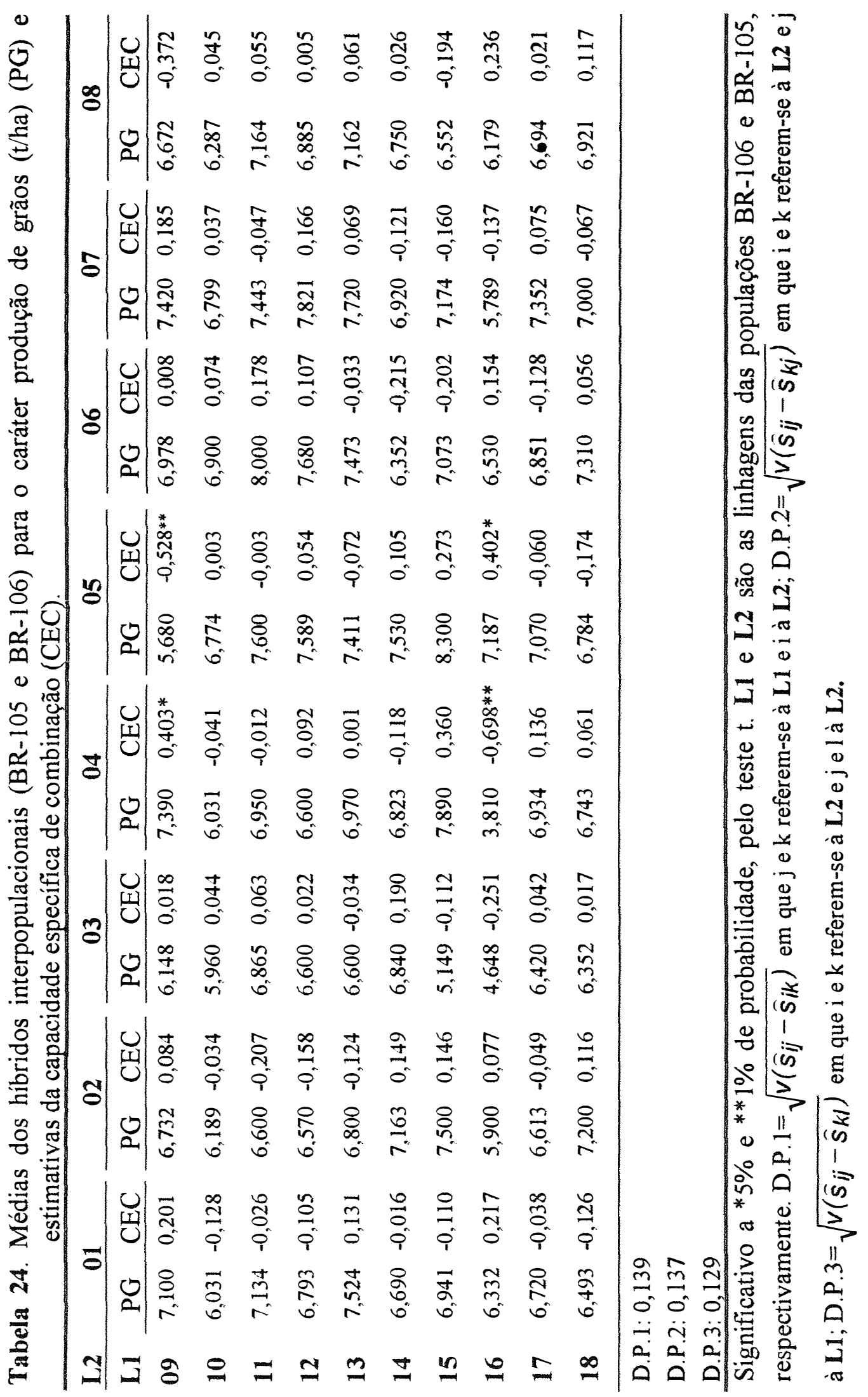




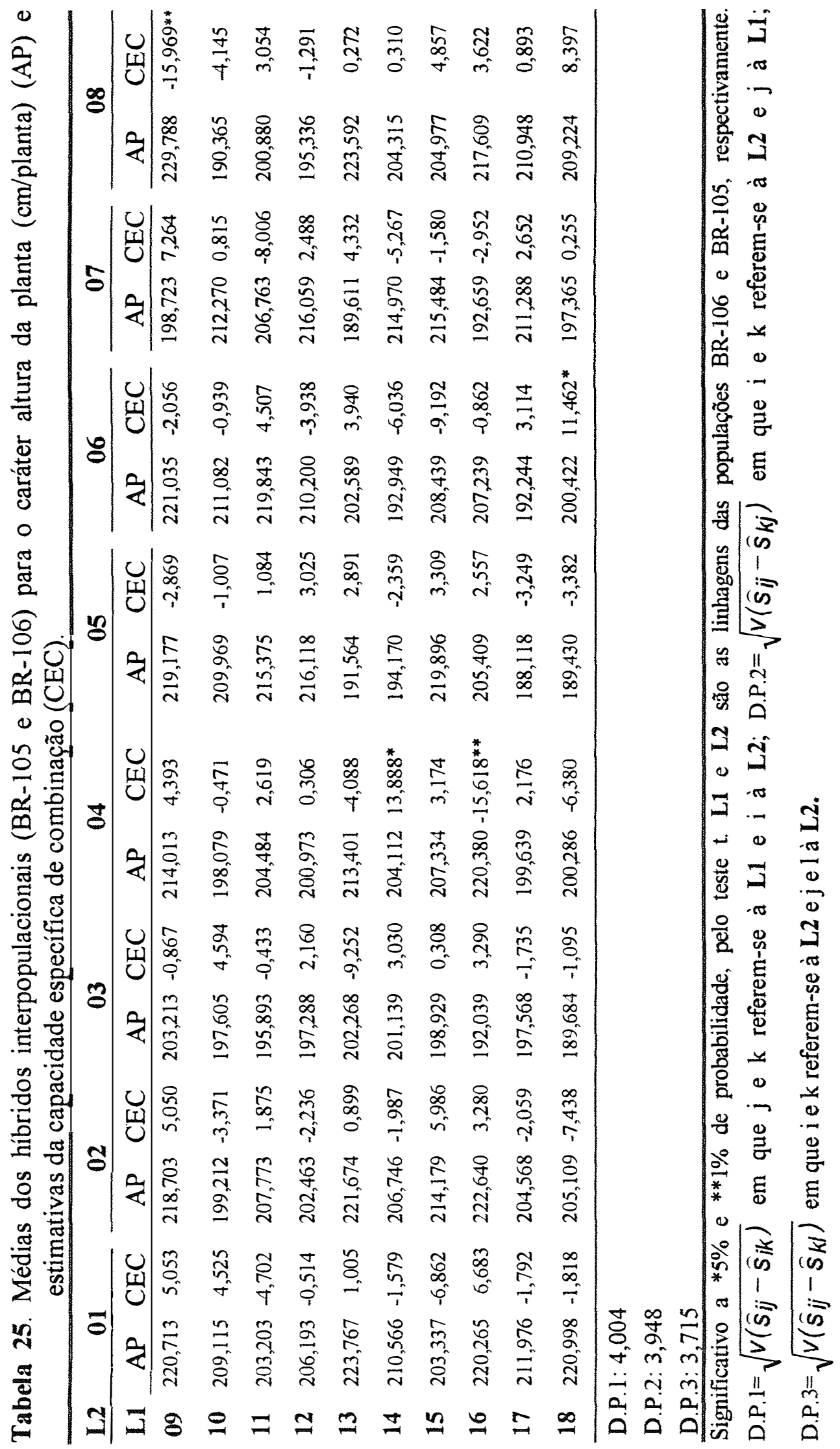




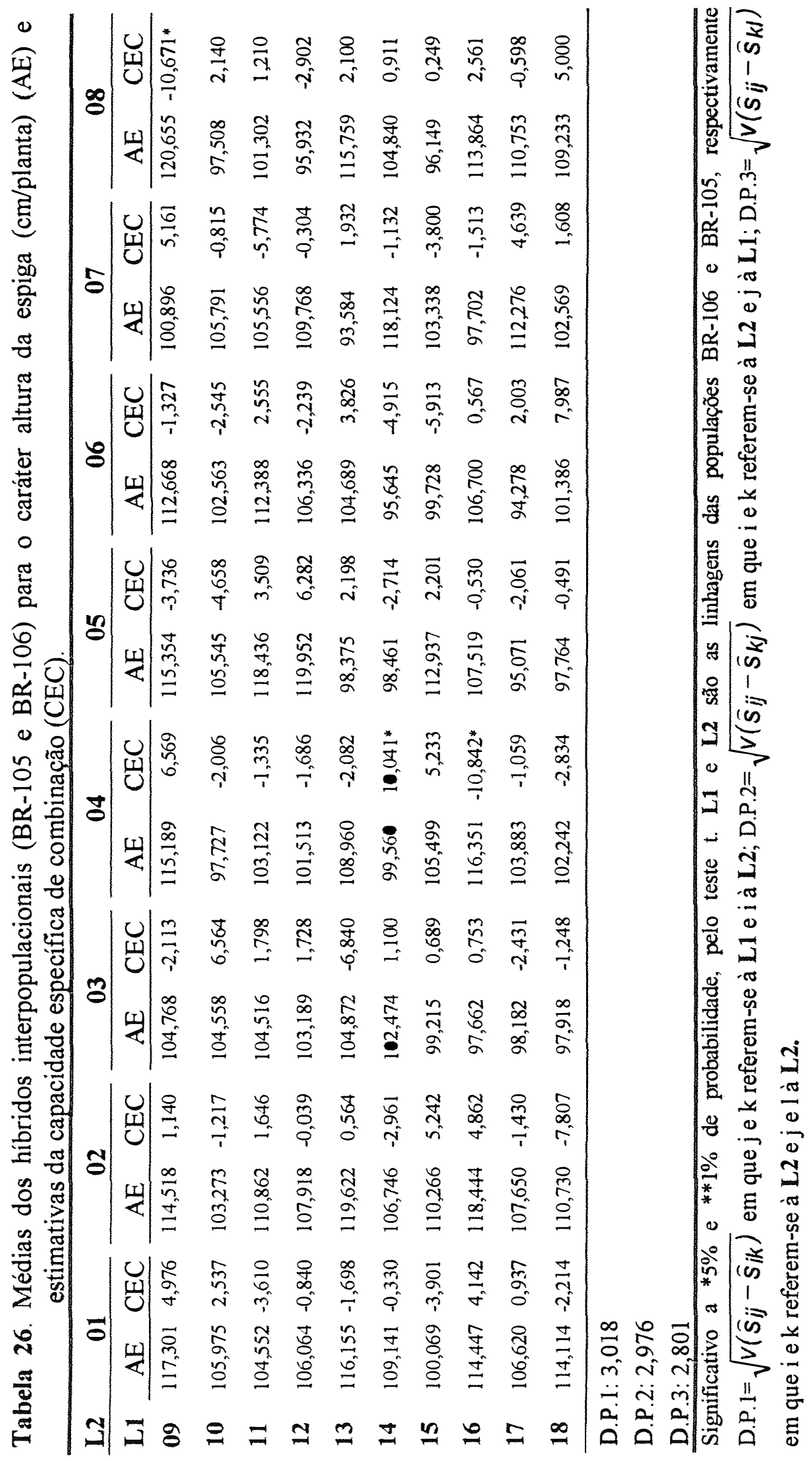




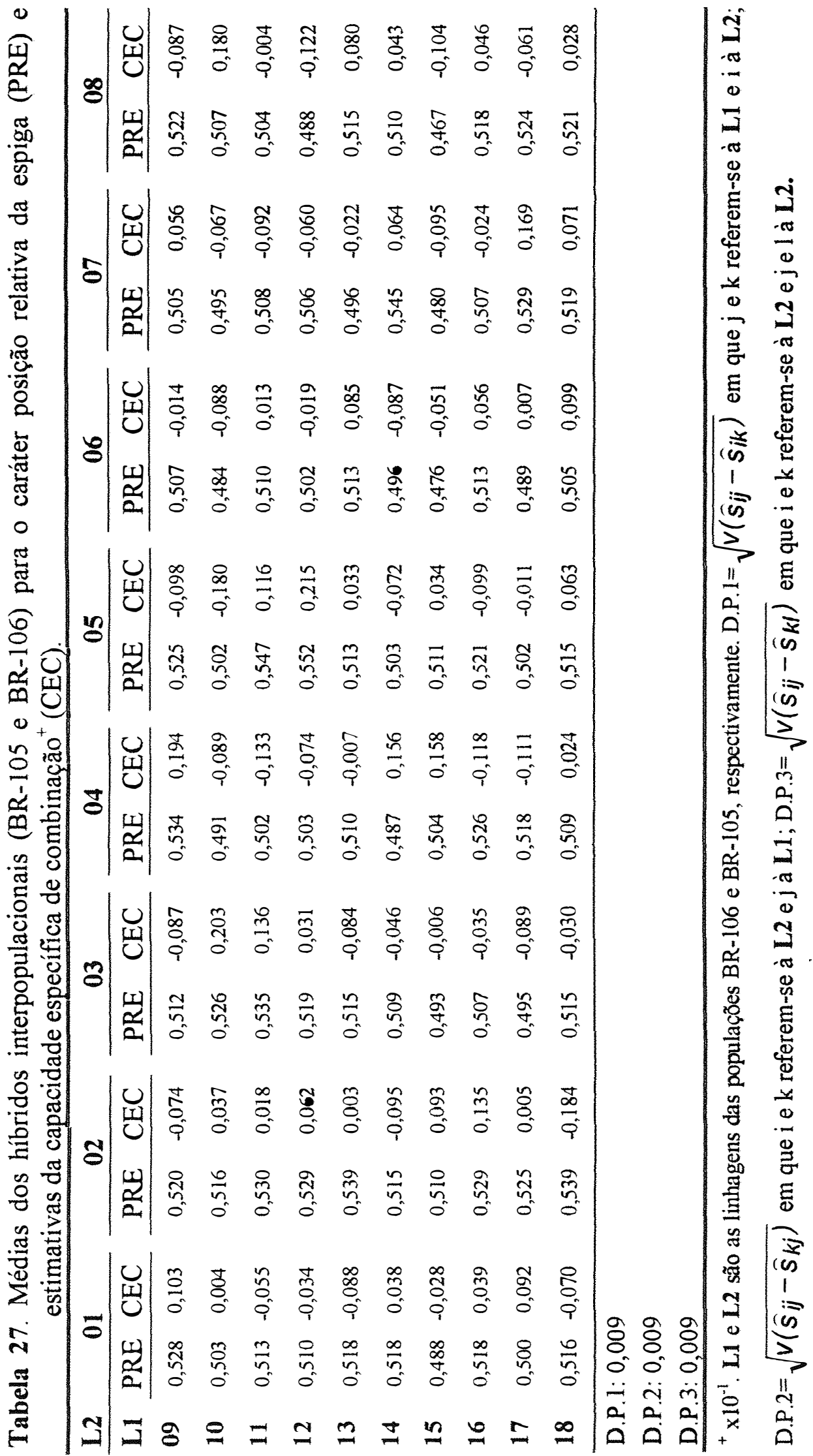




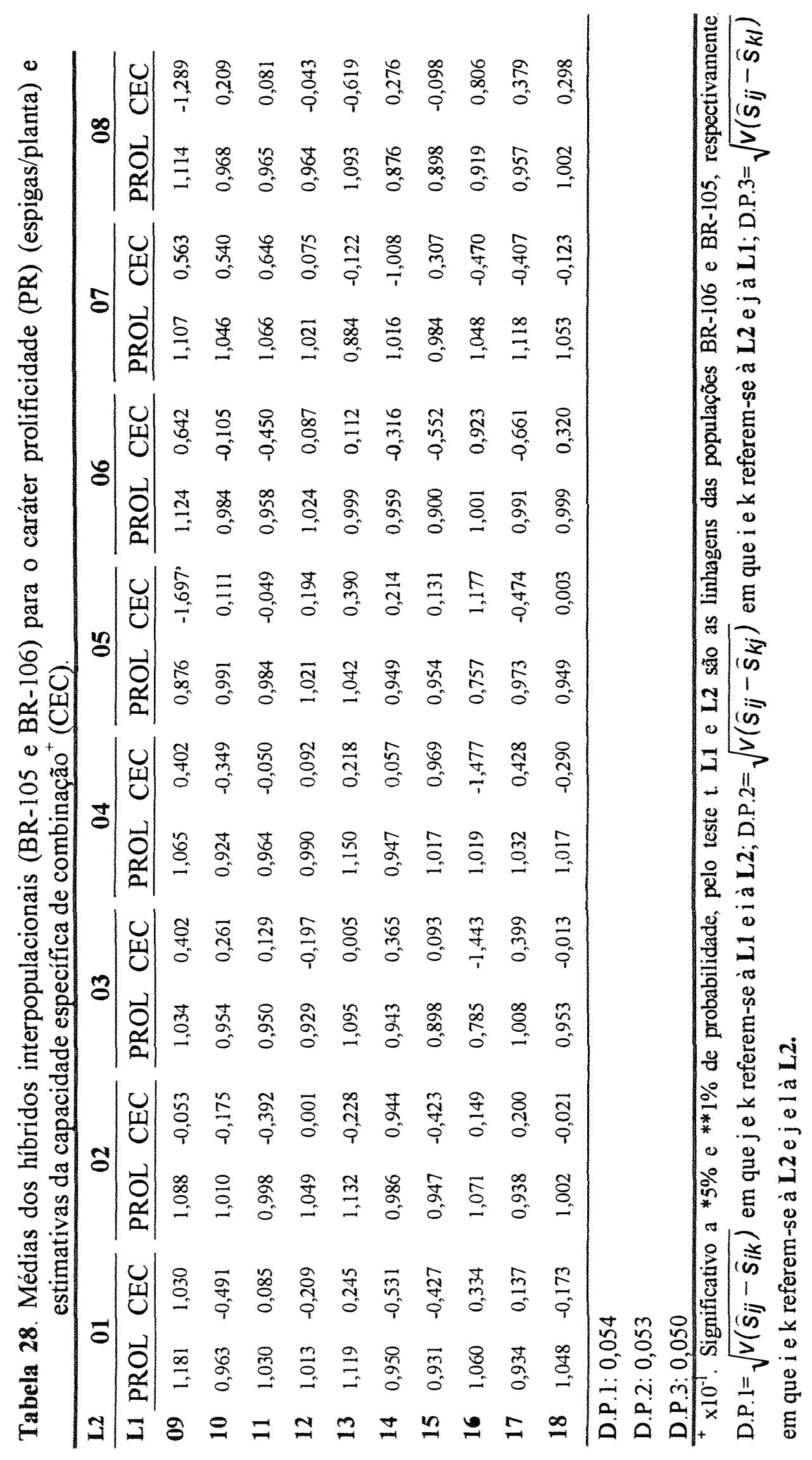




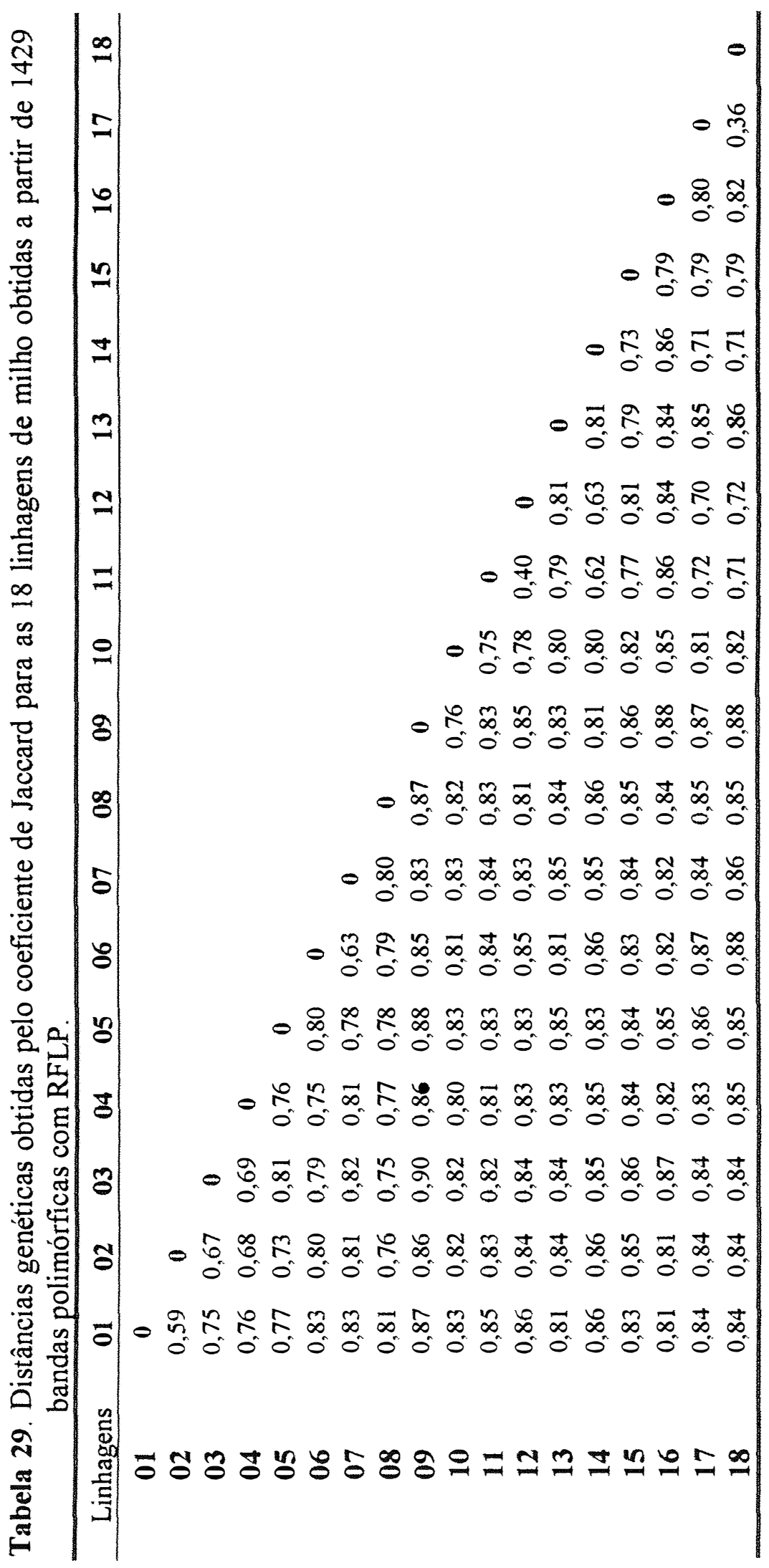


Tabela 30. Médias de produção de grãos (PG) em t/ha, médias das estimativas da capacidade específica de combinação (CEC), médias das distâncias genéticas (DG) e estimativas de correlação entre CEC e DG (r) para todas as linhagens e para os diferentes grupos, na população BR-105.

Combinações das

Linhagens
Entre todas as
Grupo I (GI)

$(01,03,04,05,08)$

Grupo II (GII)

$(02,06,07)$

\begin{tabular}{ccccc}
$N$ & PG & CEC & DG & r \\
\hline 28 & 6,59 & 0,000 & 0,76 & $0,17^{\text {ns }}$
\end{tabular}

GI $x$ GII

10

$6,46-0,309$

0,76

$-0,06^{\text {ns }}$

Significativo a ${ }^{*} \% \mathrm{e}^{* *} 1 \%$ de probabilidade, pelo teste $\mathrm{t} \mathrm{e}^{\mathrm{ns}}$ não significativo.

$\mathrm{N}$ é o número de combinações.

Tabela 31. Médias de produção de grãos (PG) em t/ha, médias das estimativas da capacidade específica de combinação (CEC), médias das distâncias genéticas (DG) e estimativas de correlação entre CEC e DG (r) para todas as linhagens e para os diferentes grupos, na população BR-106.

\begin{tabular}{lccccc}
\hline $\begin{array}{l}\text { Combinações das } \\
\text { Linhagens }\end{array}$ & N & PG & CEC & DG & r \\
\hline $\begin{array}{l}\text { Entre todas as linhagens } \\
\text { Grupo I (GI) }\end{array}$ & 36 & 5,95 & 0,000 & 0,76 & $0,47^{* *}$ \\
$(09,10,13,15)$ & 06 & 7,08 & $-0,891$ & 0,81 & $0,60^{\text {ns }}$ \\
Grupo II $(\mathrm{GII})$ & 10 & 3,64 & $-0,535$ & 0,63 & $0,24^{\text {ns }}$ \\
$(11,12,14,17,18)$ & 20 & 6,76 & 0,535 & 0,81 & $0,26^{\text {ns }}$ \\
GI x GII & & &
\end{tabular}

Significativo a $* 5 \% \mathrm{e}^{* *} 1 \%$ de probabilidade, pelo teste $\mathrm{t} \mathrm{e}^{\text {ns }}$ não significativo.

$\mathrm{N}$ é o número de combinações.

A linhagem 16 foi excluída por causa de perdas de dados. 
Tabela 32. Médias de produção de grãos (PG) em t/ha, médias das estimativas da capacidade específica de combinação (CEC), médias das distâncias genéticas (DG) e estimativas de correlação entre CEC e DG (r) para todas as linhagens $\mathrm{e}$ para os diferentes grupos nos híbridos interpopulacionais.

\begin{tabular}{|c|c|c|c|c|c|}
\hline $\begin{array}{l}\text { Combinações das } \\
\text { Linhagens }\end{array}$ & $\mathrm{N}$ & PG & $\mathrm{CEC}$ & DG & $r$ \\
\hline Entre todas as linhagens & 136 & 6,48 & 0,000 & 0,80 & $0,08^{\mathrm{ns}}$ \\
\hline $\begin{array}{l}\text { Grupo I (GI) - BR-105 } \\
(01,03,04,05,08)\end{array}$ & 10 & 6,46 & $-0,309$ & 0,76 & $-0,06^{\text {ns }}$ \\
\hline $\begin{array}{l}\text { Grupo II (GII) - BR-106 } \\
(09,10,13,15)\end{array}$ & 06 & 7,08 & $-0,891$ & 0,81 & $0,60^{\text {ns }}$ \\
\hline $\begin{array}{l}\text { Grupo III (GIII) - BR-105 } \\
(02,06,07)\end{array}$ & 03 & 5,32 & $-1,029$ & 0,74 & $1,00^{* *}$ \\
\hline $\begin{array}{l}\text { Grupo IV (GIV)-BR-106 } \\
(11,12,14,17,18)\end{array}$ & 10 & 3,64 & $-0,535$ & 0,63 & $0,24^{\mathrm{ns}}$ \\
\hline GI x GII - inter & 20 & 6,73 & $-0,002$ & 0,84 & $-0,14^{\text {ns }}$ \\
\hline GI x GIII - intra & 15 & 6,97 & 0,412 & 0,76 & $0,32^{\mathrm{ns}}$ \\
\hline GI x GIV - inter & 25 & 6,87 & 0,013 & 0,82 & $-0,33^{\text {ns }}$ \\
\hline GII x GIII - inter & 12 & 7,06 & 0,004 & 0,83 & $0,24^{\mathrm{ns}}$ \\
\hline GII x GIV - intra & 20 & 6,76 & 0,535 & 0,81 & $0,26^{\mathrm{ns}}$ \\
\hline GIII x GIV - inter & 15 & 7,12 & $-0,009$ & 0,85 & $-0,19^{\mathrm{ns}}$ \\
\hline
\end{tabular}

Significativo a $* 5 \%$ e ${ }^{* *} 1 \%$ de probabilidade, pelo teste $t \mathrm{e}^{\mathrm{ns}}$ não significativo. $\mathrm{N}$ é o número de combinações.

A linhagem 16 foi excluída por causa de perdas de dados. 
Tabela 33. Médias de altura da planta (AP) em $\mathrm{cm} / \mathrm{planta}$, médias das estimativas da capacidade específica de combinação (CEC), médias das distâncias genéticas (DG) e estimativas de correlação entre CEC e DG (r) para todas as linhagens e para os diferentes grupos, na população BR-105.

Combinações das

\begin{tabular}{lccccc}
$\begin{array}{l}\text { Linhagens } \\
\text { Entre todas as linhagens }\end{array}$ & N & AP & CEC & DG & r \\
Grupo I (Gl) & 28 & 210,01 & 0,000 & 0,76 & $0,15^{\text {ns }}$ \\
$(01,02,04,05,08)$ & 10 & 208,20 & $-2,124$ & 0,74 & $-0,03^{\text {ns }}$ \\
$\begin{array}{l}\text { Grupo II (GII) } \\
(03,06,07)\end{array}$ & 03 & 202,42 & $-7,081$ & 0,75 & $1,00^{* *}$ \\
GI x GII & 15 & 212,74 & 2,832 & 0,78 & $-0,19^{\text {ns }}$ \\
\hline
\end{tabular}

Significativo a $* 5 \%$ e ${ }^{* *} 1 \%$ de probabilidade, pelo teste $\mathrm{t} \mathrm{e}^{\mathrm{ns}}$ não significativo. $\mathrm{N}$ é o número de combinações.

Tabela 34. Médias de altura da planta $(\mathrm{AP}) \mathrm{em} \mathrm{cm} / \mathrm{planta}$, médias das estimativas da capacidade específica de combinação (CEC), médias das distâncias genéticas (DG) e estimativas de correlação entre CEC e DG (r) para todas as linhagens e para os diferentes grupos, na população BR-106.

Combinações das

Linhagens 促

Entre todas as linhagens

\begin{tabular}{ccccc} 
N & AP & CEC & DG & r \\
\hline 36 & 205,58 & 0,000 & 0,76 & $0,27^{\text {ns }}$
\end{tabular}

Grupo I (GI)

$(09,11,12,17)$

$06 \quad 201,12 \quad-1,394 \quad 0,73 \quad-0,60^{\text {ns }}$

Grupo II (GII)

$(10,13,14,15,18)$

10

$205,76 \quad-1,823$

0,79

$0,43^{\text {ns }}$

GI x GII

20

206,84

1,329

0,75

$0,43^{\text {ns }}$

Significativo a $* 5 \%$ e ${ }^{* *} 1 \%$ de probabilidade, pelo teste $t \mathrm{e}^{\text {ns }}$ não significativo. $\mathrm{N}$ é o número de combinações.

A linhagem 16 foi excluída por causa de perdas de dados. 
Tabela 35. Médias de altura da planta (AP) em $\mathrm{cm} /$ planta, médias das estimativas da capacidade específica de combinação (CEC), médias das distâncias genéticas (DG) e estimativas de correlação entre CEC e DG (r) para todas as linhagens e para os diferentes grupos nos híbridos interpopulacionais.

\begin{tabular}{lccccc}
\hline $\begin{array}{l}\text { Combinações das } \\
\text { Linhagens }\end{array}$ & N & AP & CEC & DG & r \\
\hline Entre todas as linhagens & 136 & 206,85 & 0,000 & 0,80 & $0,06^{\text {ns }}$ \\
$\begin{array}{l}\text { Grupo I (GI) } \\
(01,02,04,11,12,18)\end{array}$ & 15 & 205,33 & $-1,746$ & 0,76 & $-0,25^{\text {ns }}$ \\
$\begin{array}{l}\text { Grupo II (GII) } \\
(05,08,09,17)\end{array}$ & 06 & 206,77 & $-6,846$ & 0,85 & $0,03^{\text {ns }}$ \\
Grupo III (GIII) & 21 & 204,32 & $-3,065$ & 0,81 & $0,29^{\text {ns }}$ \\
$(03,06,07,10,13,14,15)$ & 24 & 207,38 & 1,069 & 0,79 & $0,33^{\text {ns }}$ \\
GI x GII & 42 & 207,95 & 1,412 & 0,80 & $0,08^{\text {ns }}$ \\
GI x GIII & 28 & 207,49 & 1,901 & 0,82 & $-0,11^{\text {ns }}$ \\
GII x GIII & & &
\end{tabular}

${ }^{\text {ns }}$ não significativo pelo teste $t$.

$\mathrm{N}$ é o número de combinações.

A linhagem 16 foi excluída por causa de perdas de dados.

Tabela 36. Médias de altura da espiga $(\mathrm{AE}) \mathrm{em} \mathrm{cm} / \mathrm{planta}$, médias das estimativas da capacidade específica de combinação (CEC), médias das distâncias genéticas (DG) e estimativas de correlação entre CEC e DG (r) para todas as linhagens e para os diferentes grupos, na população BR-105.

Combinações das

Linhagens as

Entre todas as linhagens

N

$\mathrm{AE}$

CEC

DG

\begin{tabular}{c} 
estimativas \\
distâncias \\
DG (r) para \\
híbridos \\
\hline $0,06^{\text {ns }}$ \\
$-0,25^{\text {ns }}$ \\
$0,03^{\text {ns }}$ \\
$0,29^{\text {ns }}$ \\
$0,33^{\text {ns }}$ \\
$0,08^{\text {ns }}$ \\
$-0,11^{\text {ns }}$
\end{tabular}


Tabela 37. Médias de altura da espiga $(\mathrm{AE}) \mathrm{em} \mathrm{cm} / \mathrm{planta}$, médias das estimativas da capacidade específica de combinação (CEC), médias das distâncias genéticas (DG) e estimativas de correlação entre CEC e DG (r) para todas as linhagens e para os diferentes grupos, na população BR-106.

\begin{tabular}{|c|c|c|c|c|c|}
\hline $\begin{array}{l}\text { Combinações das } \\
\text { Linhagens }\end{array}$ & $\mathrm{N}$ & $\mathrm{AE}$ & $\mathrm{CEC}$ & DG & $r$ \\
\hline Entre todas as linhagens & 36 & 106,08 & 0,000 & 0,76 & $0,53^{* *}$ \\
\hline $\begin{array}{l}\text { Grupo I (GI) } \\
(09,17)\end{array}$ & 01 & 101,13 & $-5,186$ & 0,87 & - \\
\hline $\begin{array}{l}\text { Grupo II (GII) } \\
(10,13)\end{array}$ & 01 & 104,31 & $-6,691$ & 0,80 & - \\
\hline $\begin{array}{l}\text { Grupo III (GIII) } \\
(11,12)\end{array}$ & 01 & 101,03 & 0,000 & 0,40 & - \\
\hline $\begin{array}{l}\text { Grupo IV (GIV) } \\
(14,15,18)\end{array}$ & 03 & 100,25 & $-3,747$ & 0,74 & $1,00^{* *}$ \\
\hline GI x GII & 04 & 110,11 & 1,448 & 0,81 & $-0,40^{\mathrm{ns}}$ \\
\hline GI x GIII & 04 & 105,86 & 0,455 & 0,77 & $0,60^{\mathrm{ns}}$ \\
\hline GI x GIV & 06 & 106,60 & 1,453 & 0,73 & $0,83^{*}$ \\
\hline GII x GIII & 04 & 108,12 & 0,371 & 0,78 & $0,40^{\text {ns }}$ \\
\hline GII x GIV & 06 & 108,52 & 1,017 & 0,81 & $-0,64^{\mathrm{ns}}$ \\
\hline GIII $x$ GIV & 06 & 104,11 & $-0,133$ & 0,71 & $0,77^{\mathrm{ns}}$ \\
\hline
\end{tabular}

Significativo a ${ }^{*} \% \mathrm{e}^{* *} 1 \%$ de probabilidade, pelo teste $\mathrm{t} \mathrm{e}^{\mathrm{ns}}$ não significativo. $\mathrm{N}$ é o número de combinações.

A linhagem 16 foi excluída por causa de perdas de dados. 
Tabela 38. Médias de altura da espiga (AE) em $\mathrm{cm} / \mathrm{planta}$, médias das estimativas da capacidade específica de combinação (CEC), médias das distâncias genéticas (DG) e estimativas de correlação entre CEC e DG (r) para todas as linhagens $\mathrm{e}$ para os diferentes grupos nos híbridos interpopulacionais.

\begin{tabular}{lccccc}
\hline $\begin{array}{l}\text { Combinações das } \\
\text { Linhagens }\end{array}$ & $\mathrm{N}$ & AE & CEC & DG & $\mathrm{r}$ \\
\hline Entre todas as linhagens & 136 & 107,24 & 0,000 & 0,80 & $0,06^{\text {ns }}$ \\
Grupo I (GI) & 15 & 111,03 & $-2,239$ & 0,78 & $-0,04^{\text {ns }}$ \\
$(01,02,03,04,13,18)$ & 15 & 105,06 & $-2,880$ & 0,75 & $0,15^{\text {ns }}$ \\
Grupo II $(G I 1)$ & 10 & 106,39 & $-3,615$ & 0,83 & $-0,37^{\text {ns }}$ \\
$(06,07,11,12,14,15)$ & 10 & 106,01 & 1,019 & 0,82 & $0,22^{\text {ns }}$ \\
Grupo III $(G I I I)$ & $365,08,09,10,17)$ & 107,36 & 1,057 & 0,80 & $0,10^{\text {ns }}$ \\
GI x GII & 30 & 108,07 & 1,484 & 0,81 & 0,00 \\
GI x GIII & 30 & & & \\
GII x GIII & &
\end{tabular}

${ }^{n s}$ não significativo pelo teste $t$.

$\mathrm{N}$ é o número de combinações.

A linhagem 16 foi excluída por causa de perdas de dados. 
Tabela 39. Médias de posição relativa da espiga (PRE), médias das estimativas da capacidade especifica de combinação (CEC), médias das distâncias genéticas (DG) e estimativas de correlação entre CEC e DG (r) para todas as linhagens e para os diferentes grupos, na população BR-105.

\begin{tabular}{|c|c|c|c|c|c|}
\hline $\begin{array}{l}\text { Combinações das } \\
\text { Linhagens }\end{array}$ & $\mathrm{N}$ & PRE & CEC & DG & $r$ \\
\hline Entre todas as linhagens & 28 & 0,52 & 0,000 & 0,76 & $0,22^{\text {ns }}$ \\
\hline $\begin{array}{l}\text { Grupo I (Gl) } \\
(01,02,04)\end{array}$ & 03 & 0,51 & $-0,008$ & 0,67 & $0,50^{\text {ns }}$ \\
\hline $\begin{array}{l}\text { Grupo II (GII) } \\
(03,05,06,07,08)\end{array}$ & 10 & 0,52 & $-0,014$ & 0,77 & $0,26^{\mathrm{ns}}$ \\
\hline GI x GII & 15 & 0,52 & 0,003 & 0,77 & $-0,05^{\mathrm{ns}}$ \\
\hline
\end{tabular}

Tabela 40. Médias de posição relativa da espiga (PRE), médias das estimativas da capacidade específica de combinação (CEC), médias das distâncias genéticas (DG) e estimativas de correlação entre CEC e DG (r) para todas as linhagens e para os diferentes grupos, na população BR-106.

\begin{tabular}{lccccc}
\hline $\begin{array}{l}\text { Combinações das } \\
\text { Linhagens }\end{array}$ & $\mathrm{N}$ & PRE & CEC & DG & $\mathrm{r}$ \\
\hline $\begin{array}{l}\text { Entre todas as linhagens } \\
\text { Grupo I (GI) }\end{array}$ & 36 & 0,51 & 0,000 & 0,76 & $-0,17^{\text {ns }}$ \\
$(11,12)$ & 01 & 0,51 & 0,000 & 0,40 & - \\
Grupo II (GII) & 21 & 0,51 & 0,002 & 0,78 & $-0,24^{\text {ns }}$ \\
$(09,10,13,14,15,17,18)$ & 14 & 0,51 & 0,030 & 0,75 & $-0,15^{\text {ns }}$ \\
GI x GII & & & & &
\end{tabular}

${ }^{\text {TIs }}$ não significativo pelo teste $t$.

$\mathrm{N}$ é o número de combinações.

A linhagem 16 foi excluída por causa de perdas de dados. 
Tabela 41. Médias de posição relativa da espiga (PRE), médias das estimativas da capacidade específica de combinação (CEC), médias das distâncias genéticas (DG) e estimativas de correlação entre CEC e DG (r) para todas as linhagens e para os diferentes grupos nos híbridos interpopulacionais.

\begin{tabular}{lccccc}
\hline $\begin{array}{l}\text { Combinações das } \\
\text { Linhagens }\end{array}$ & N & PRE & CEC & DG & r \\
\hline Entre todas as linhagens & 136 & 0,51 & 0,000 & 0,80 & $0,01^{\text {ns }}$ \\
$\begin{array}{l}\text { Grupo I (GI) } \\
(01,02,13,18)\end{array}$ & 06 & 0,52 & $-0,008$ & 0,79 & $0,33^{\text {ns }}$ \\
$\begin{array}{l}\text { Grupo II (GII) } \\
(04,07,11,12)\end{array}$ & 06 & 0,51 & $-0,006$ & 0,75 & $-0,53^{\text {ns }}$ \\
Grupo III (GIII) & 06 & 0,51 & $-0,010$ & 0,85 & $0,25^{\text {ns }}$ \\
$(03,08,09,17)$ & 10 & 0,50 & $-0,017$ & 0,81 & $0,32^{\text {ns }}$ \\
Grupo IV (GIV) & 16 & 0,51 & $-0,001$ & 0,80 & $0,29^{\text {ns }}$ \\
GI x GII $06,14,15)$ & 16 & 0,51 & 0,002 & 0,79 & $-0,16^{\text {ns }}$ \\
GI x GIII & 20 & 0,51 & 0,002 & 0,81 & $0,27^{\text {ns }}$ \\
GI x GIV & 16 & 0,52 & 0,004 & 0,80 & $0,08^{\text {ns }}$ \\
GII x GIII & 20 & 0,51 & 0,002 & 0,78 & $0,22^{\text {ns }}$ \\
GII x GIV & 20 & 0,51 & 0,002 & 0,82 & $-0,05^{\text {ns }}$ \\
\hline GIII x GIV & & &
\end{tabular}

${ }^{\text {ns }}$ não significativo pelo teste $t$.

$\mathrm{N}$ é o número de combinações.

A linhagem 16 foi excluída por causa de perdas de dados. 
Tabela 42. Médias de prolificidade (PROL) (espigas/planta), médias das estimativas da capacidade específica de combinação (CEC), médias das distâncias genéticas (DG) e estimativas de correlação entre CEC e DG (r) para todas as linhagens e para os diferentes grupos, na população BR-105.

\begin{tabular}{lccccc}
\hline $\begin{array}{l}\text { Combinações das } \\
\text { Linhagens }\end{array}$ & $\mathrm{N}$ & PROL & CEC & DG & $\mathrm{r}$ \\
\hline $\begin{array}{l}\text { Entre todas as linhagens } \\
\text { Grupo I (GI) }\end{array}$ & 28 & 1,068 & 0,000 & 0,76 & $0,11^{\text {ns }}$ \\
$(01,03,04,05,08)$ & 15 & 1,047 & $-0,071$ & 0,74 & $-0,25^{\text {ns }}$ \\
$\begin{array}{l}\text { Grupo II (GII) } \\
(02,06,07)\end{array}$ & 01 & 0,910 & $-0,187$ & 0,63 & - \\
GI x GII & 12 & 1,108 & 0,031 & 0,80 & $0,05^{\text {ns }}$ \\
\hline
\end{tabular}

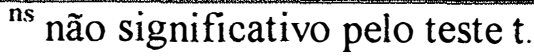

$\mathrm{N}$ é o número de combinações.

Tabela 43. Médias de prolificidade (PROL) (espigas/planta), médias das estimativas da capacidade específica de combinação (CEC), médias das distâncias genéticas (DG) e estimativas de correlação entre CEC e DG (r) para todas as linhagens e para os diferentes grupos, na população BR-106.

\begin{tabular}{lccccc}
$\begin{array}{l}\text { Combinações das } \\
\text { Linhagens }\end{array}$ & $\mathrm{N}$ & PROL & CEC & DG & $\mathrm{r}$ \\
\hline $\begin{array}{l}\text { Entre todas as linhagens } \\
\text { Grupo I (GI) }\end{array}$ & 36 & 1,014 & 0,000 & 0,76 & $0,05^{\text {ns }}$ \\
$(09,10,13,15)$ & 06 & 1,081 & $-0,055$ & 0,81 & $-0,08^{\text {ns }}$ \\
Grupo II (GII) & 10 & 0,872 & $-0,022$ & 0,63 & $0,57^{\text {ns }}$ \\
$(11,12,14,17,18)$ & 20 & 1,066 & 0,024 & 0,81 & $-0,25^{\text {ns }}$ \\
GI x GII & & & &
\end{tabular}

${ }^{\mathrm{ns}}$ não significativo pelo teste $t$.

$\mathrm{N}$ é o número de combinações.

A linhagem 16 foi excluída por causa de perdas de dados. 
Tabela 44. Médias de prolificidade (PROL) (espigas/planta), médias das estimativas da capacidade específica de combinação (CEC), médias das distâncias genéticas (DG) e estimativas de correlação entre CEC e DG (r) para todas as linhagens e para os diferentes grupos nos híbridos interpopulacionais.

\begin{tabular}{lccccc}
\hline $\begin{array}{l}\text { Combinações das } \\
\text { Linhagens }\end{array}$ & $\mathrm{N}$ & PROL & CEC & DG & $\mathrm{r}$ \\
\hline Entre todas as linhagens & 136 & 1,018 & 0,000 & 0,80 & $0,06^{\text {ns }}$ \\
$\begin{array}{l}\text { Grupo I }(\mathrm{GI}) \\
(01,03,04,05,08)\end{array}$ & 21 & 0,997 & $-0,065$ & 0,82 & $0,13^{\text {ns }}$ \\
$\begin{array}{l}\text { Grupo II }(\mathrm{GII}) \\
(09,10,13,15)\end{array}$ & 15 & 0,944 & $-0,018$ & 0,73 & $0,45^{\text {ns }}$ \\
Grupo III (GIII) & 06 & 0,985 & $-0,068$ & 0,80 & $0,32^{\text {ns }}$ \\
$(02,06,07)$ & 42 & 1,017 & 0,012 & 0,81 & $-0,11^{\text {ns }}$ \\
GI x GII & 28 & 1,061 & 0,014 & 0,82 & 0,00 \\
GI x GIII & 24 & 1,043 & 0,008 & 0,80 & $0,04^{\text {ns }}$ \\
GII x GIII & & &
\end{tabular}

ns não significativo pelo teste $t$.

$\mathrm{N}$ é o número de combinações.

A linhagem 16 foi excluída por causa de perdas de dados. 


\section{FIGURAS}




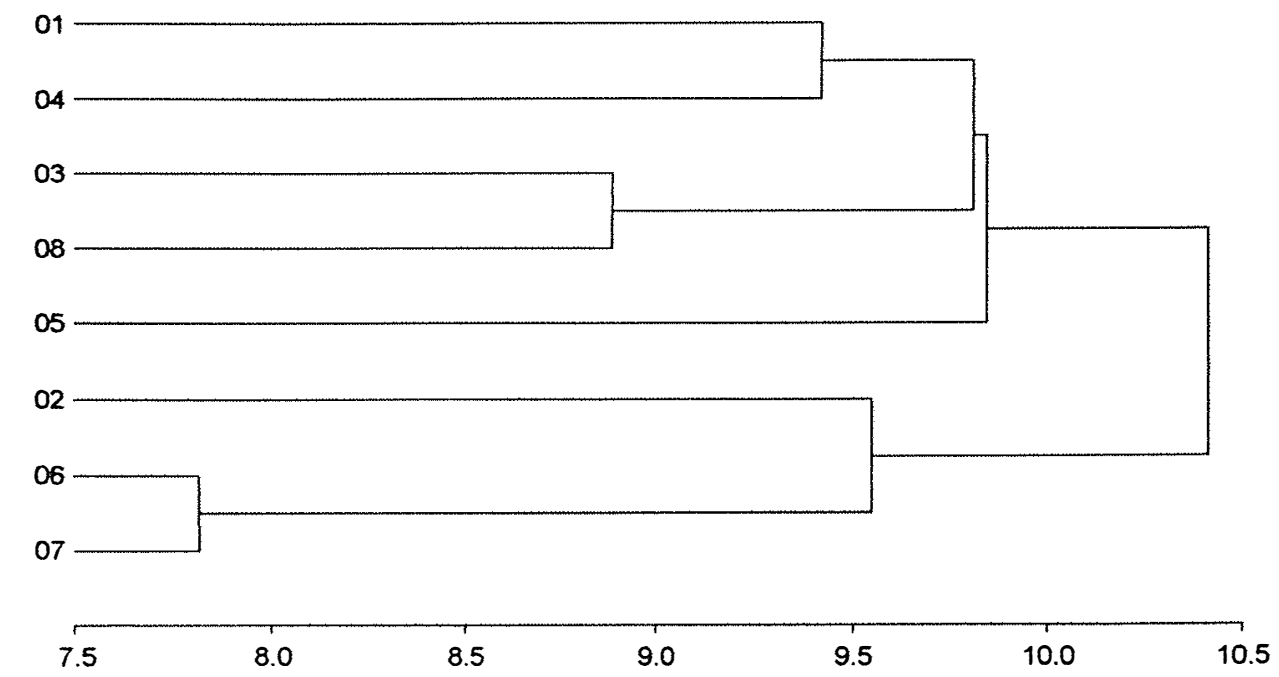

Figura 1. Dendrograma das linhagens de milho da população BR-105 agrupadas segundo o método de UPGMA, para o caráter produção de grãos.

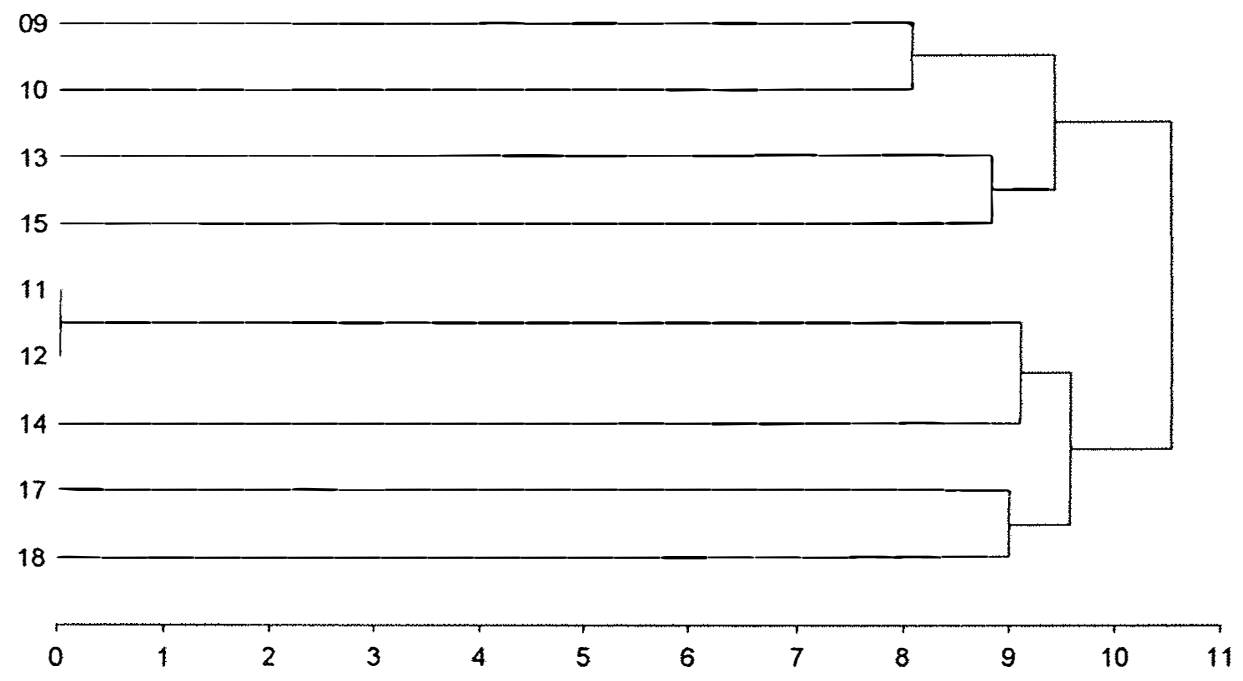

Figura 2. Dendrograma das linhagens de milho da população BR-106 agrupadas segundo o método de UPGMA, para o caráter produção de grãos. 

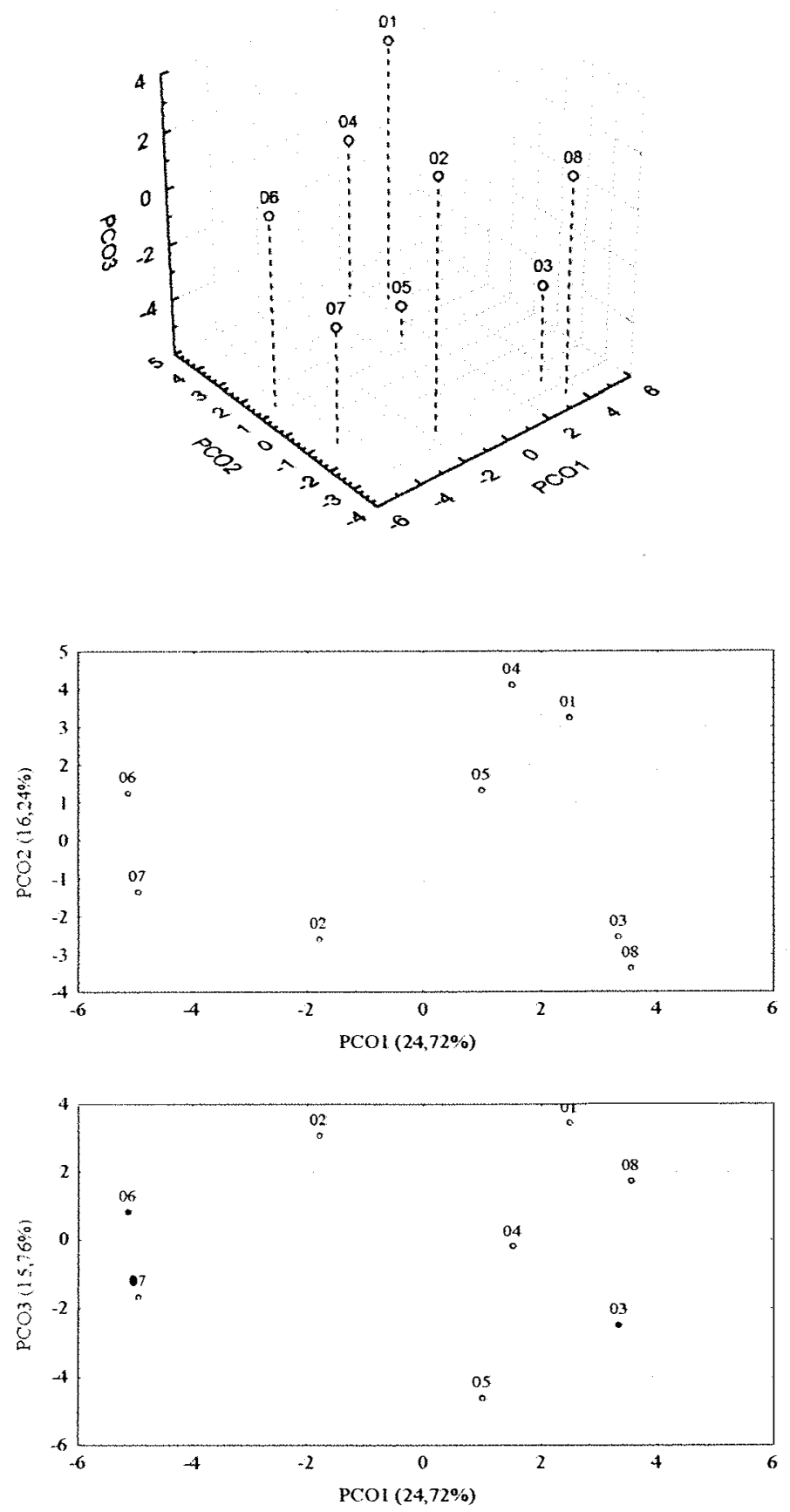

Figura 3. Associação das linhagens de milho da população BR-105 reveladas por análise de coordenadas principais (PCO) a partir das estimativas das capacidades específicas de combinação para o caráter produção de grãos. 

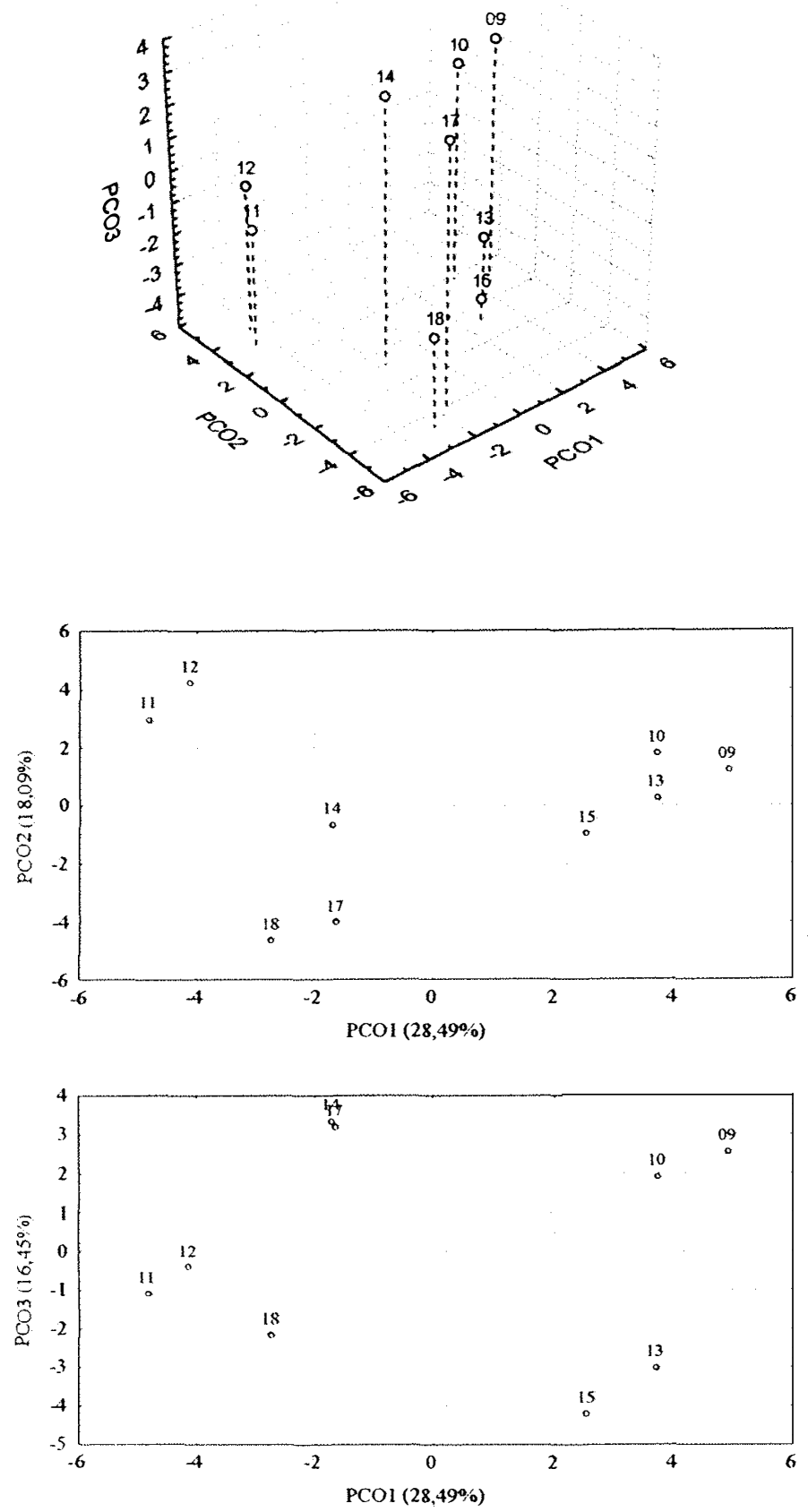

Figura 4. Associação das linhagens de milho da população BR-106 reveladas por análise de coordenadas principais (PCO) a partir das estimativas das capacidades especificas de combinação para o caráter produção de grãos. 


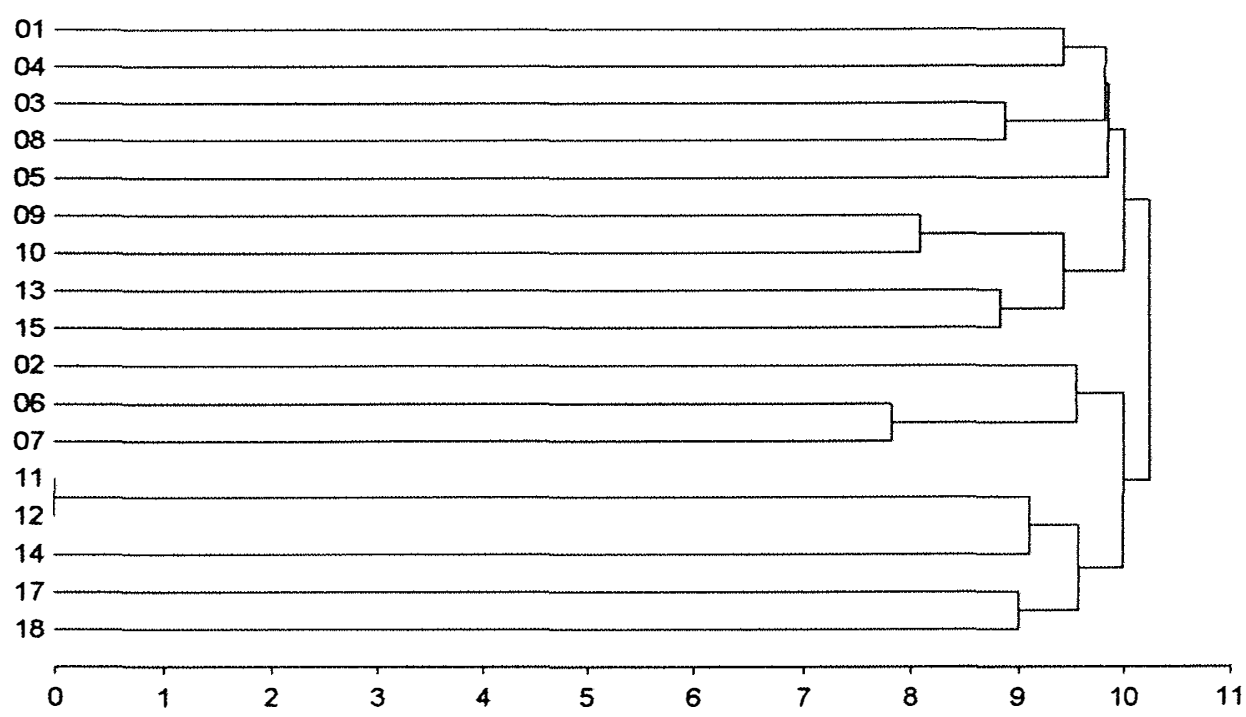

Figura 5. Dendrograma das linhagens de milho das populações BR-105 e BR-106 agrupadas segundo o método de UPGMA, para o caráter produção de grãos.

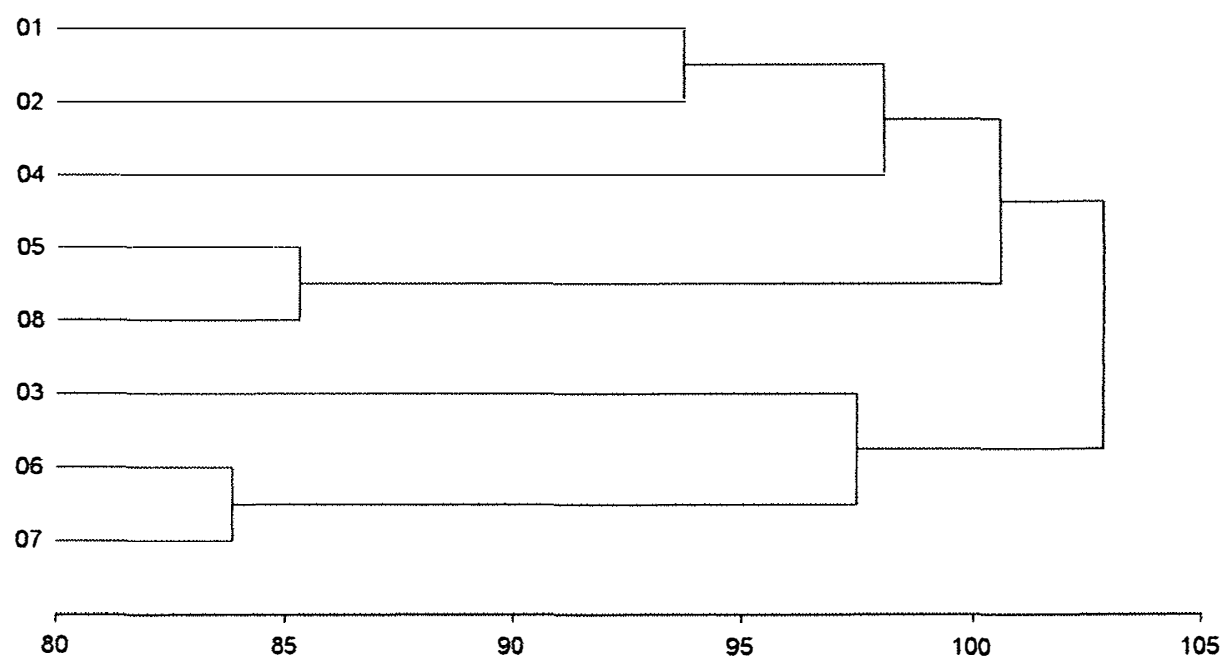

Figura 6. Dendrograma das linhagens de milho da população BR-105 agrupadas segundo o método de UPGMA, para o caráter altura da planta. 

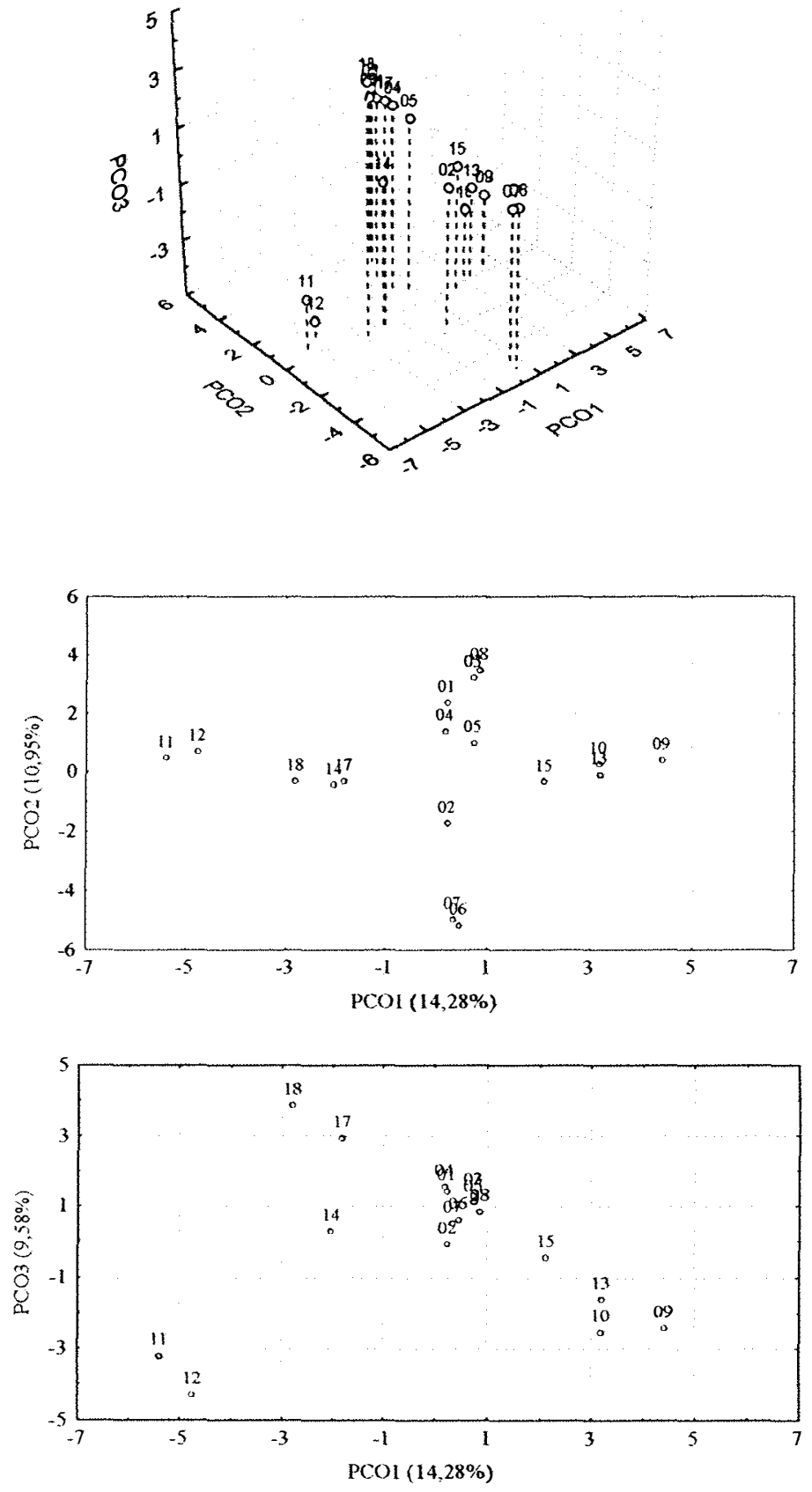

Figura 7. Associação das linhagens de milho das populações BR-105 e BR-106 reveladas por análise de coordenadas principais (PCO) a partir das estimativas das capacidades específicas de combinação para o caráter produção de grãos. 

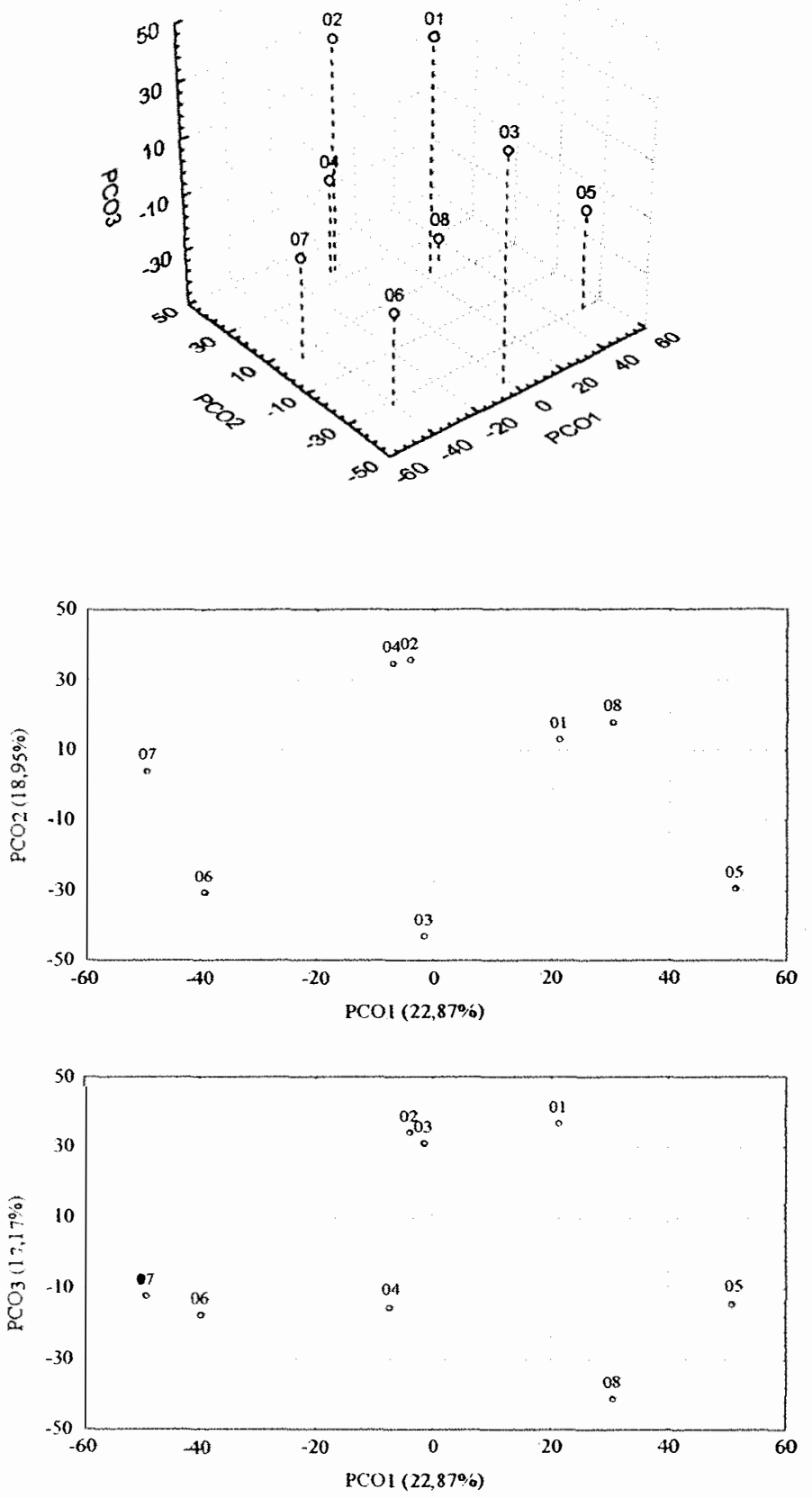

Figura 8. Associação das linhagens de milho da população BR-105 reveladas por análise de coordenadas principais (PCO) a partir das estimativas das capacidades específicas de combinação para o caráter altura da planta. 


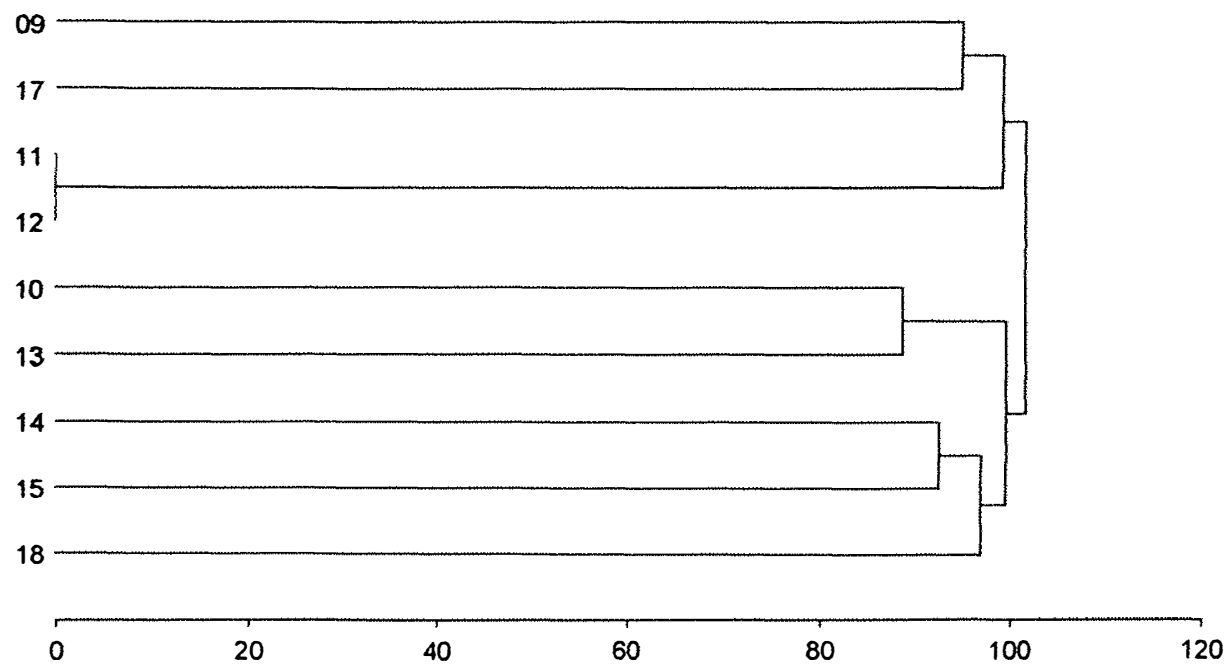

Figura 9. Dendrograma das linhagens de milho da população BR-106 agrupadas segundo o método de UPGMA, para o caráter altura da planta.

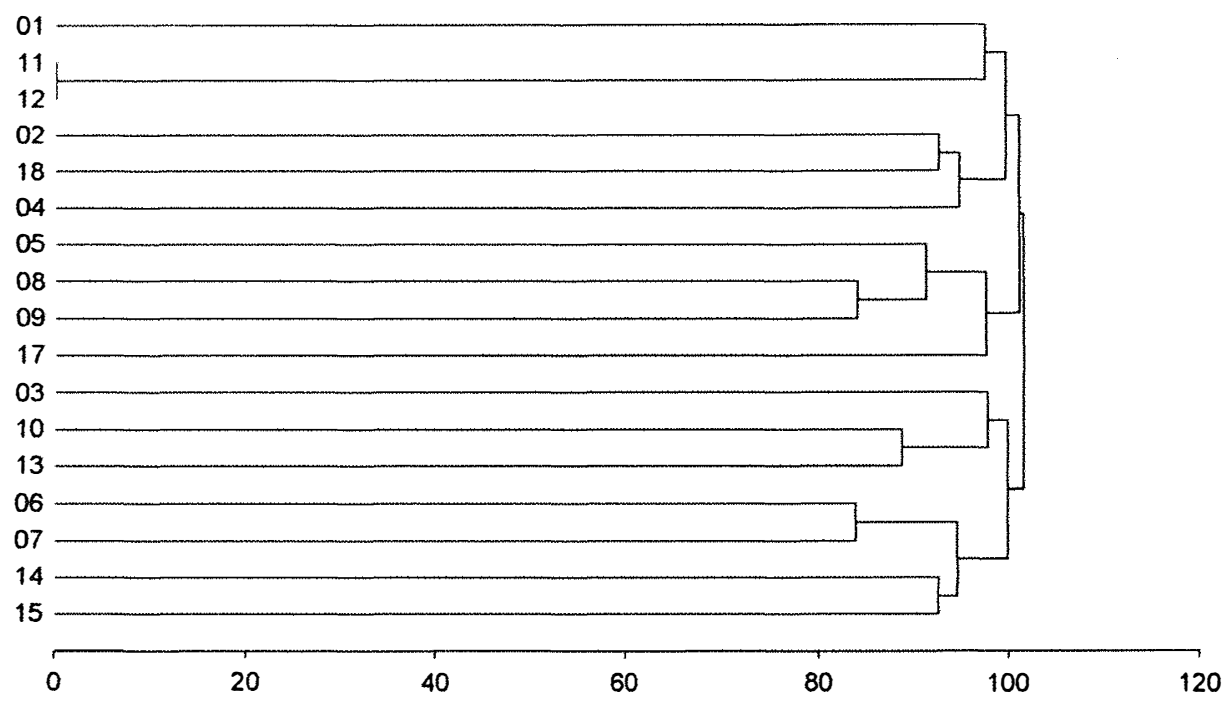

Figura 10. Dendrograma das linhagens de milho das populações BR-105 e BR-106 agrupadas segundo o método de UPGMA, para o caráter altura da planta. 

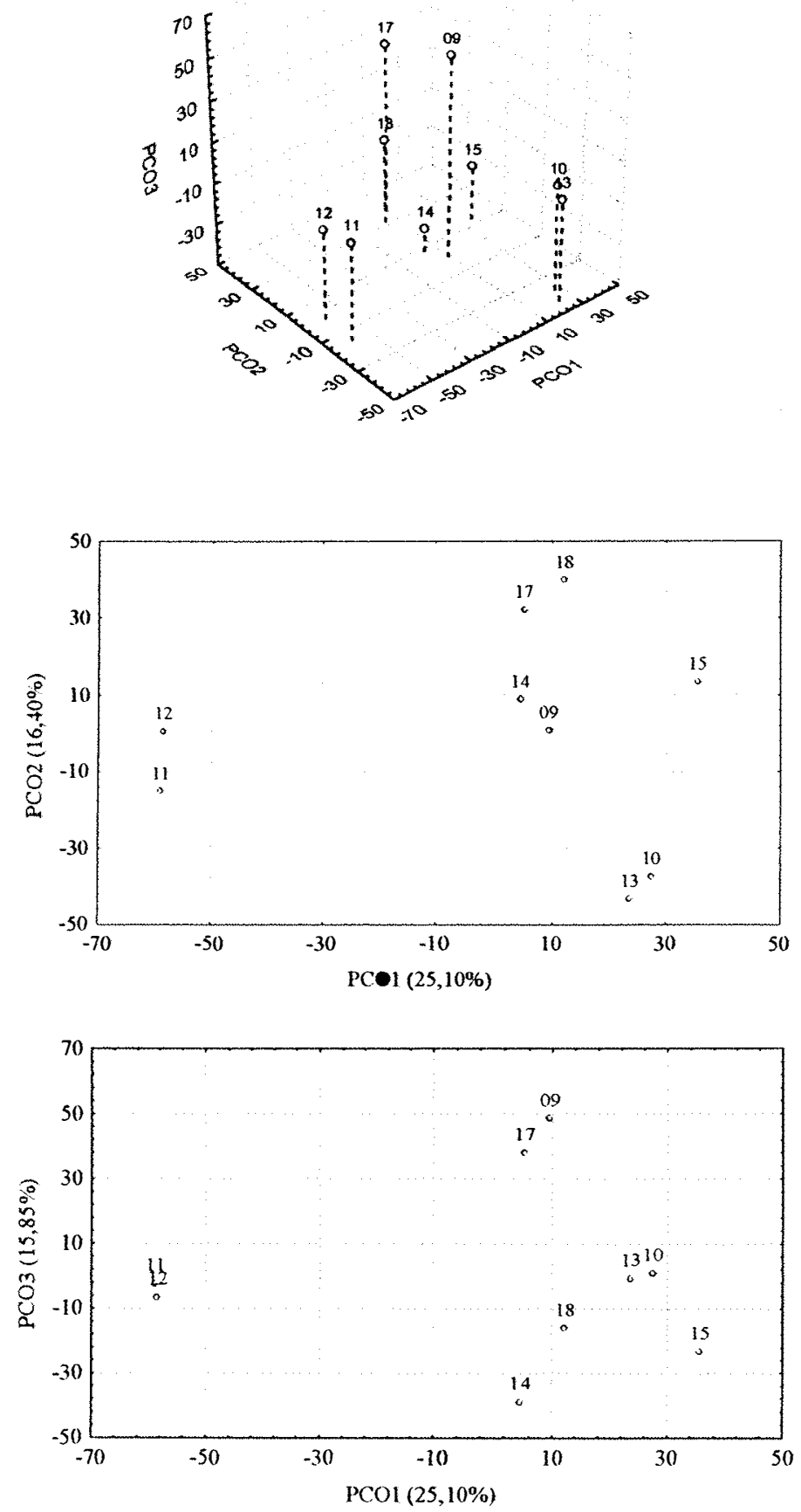

Figura 11. Associação das linhagens de milho da população BR-106 reveladas por análise de coordenadas principais (PCO) a partir das estimativas das capacidades específicas de combinação para o caráter altura da planta. 

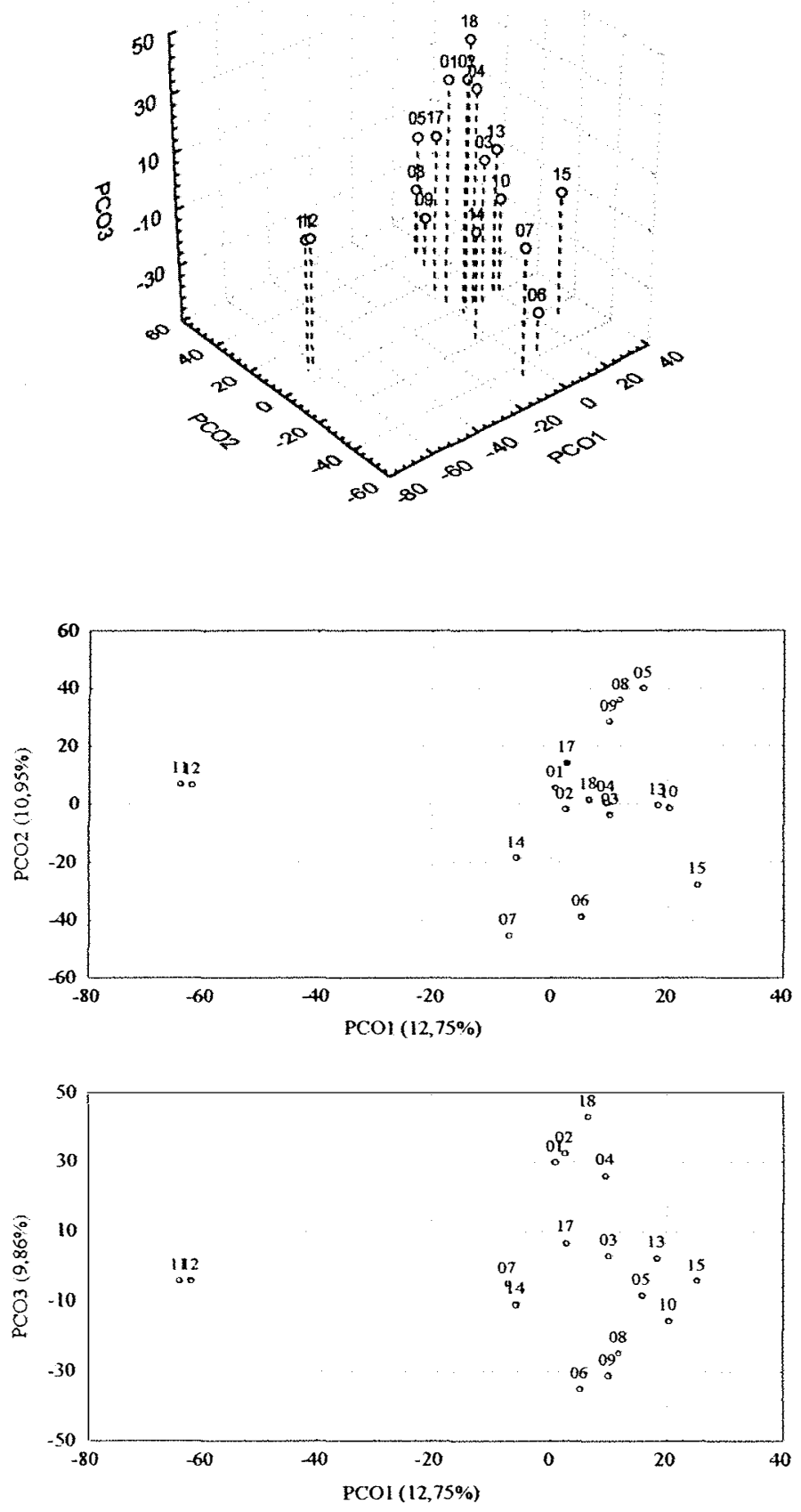

Figura 12. Associação das linhagens de milho das populações BR-105 e BR-106 reveladas por análise de coordenadas principais (PCO) a partir das estimativas das capacidades específicas de combinação para o caráter altura da planta. 


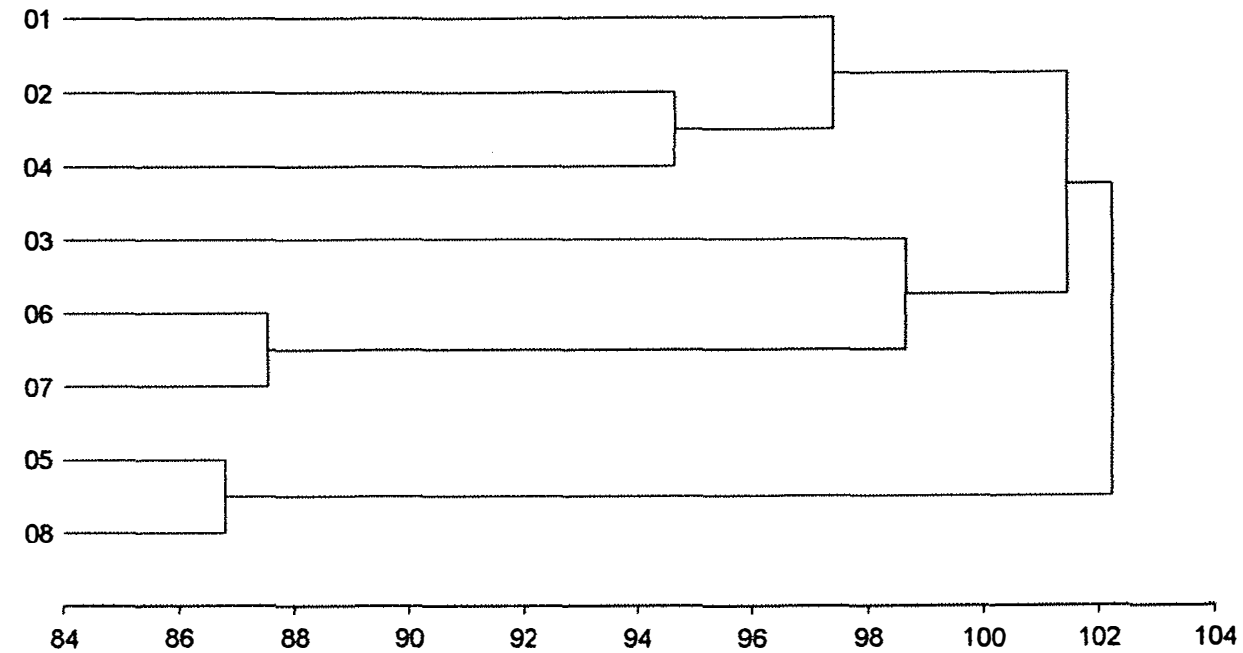

Figura 13. Dendrograma das linhagens de milho da população BR-105 agrupadas segundo o método de UPGMA, para o caráter altura da espiga.

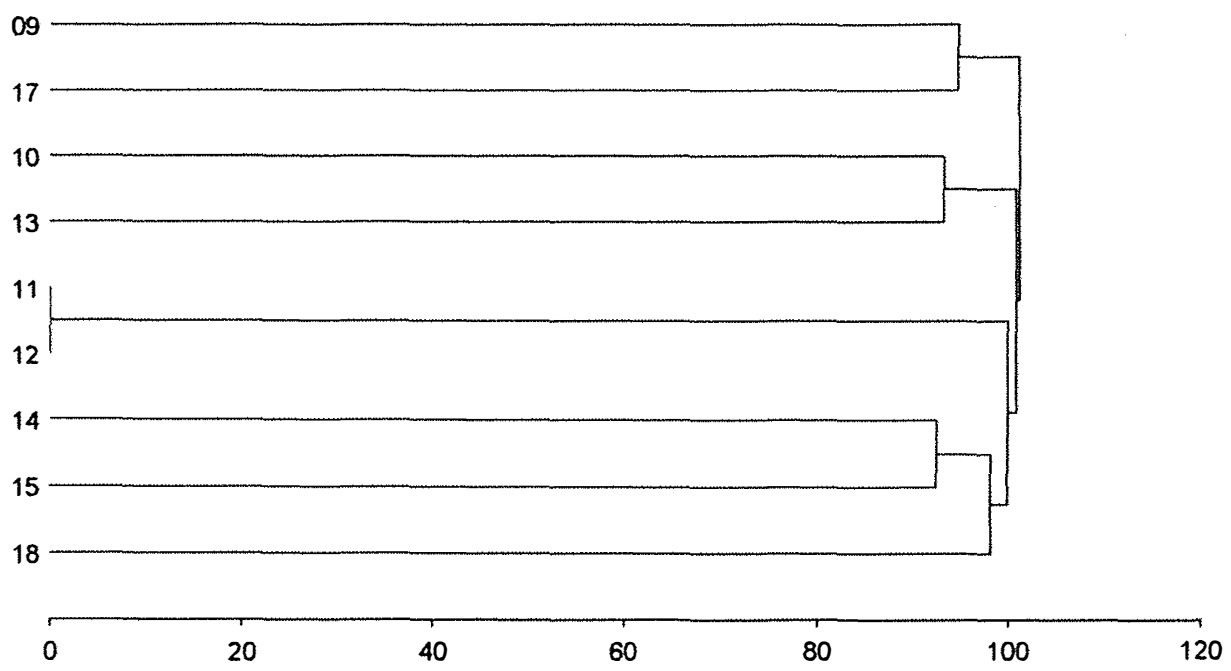

Figura 14. Dendrograma das linhagens de milho da população BR-106 agrupadas segundo o método de UPGMA, para o caráter altura da espiga. 

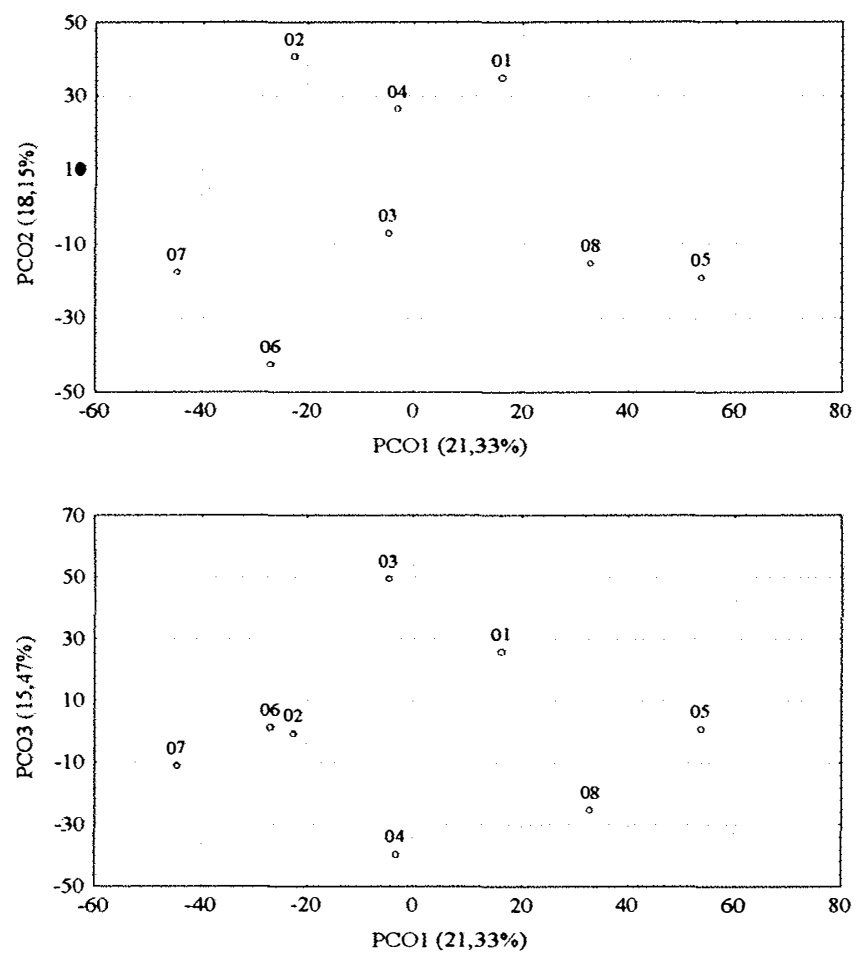

Figura 15. Associação das linhagens de milho da população BR-105 reveladas por análise de coordenadas principais (PCO) a partir das estimativas das capacidades específicas de combinação para o caráter altura da espiga. 

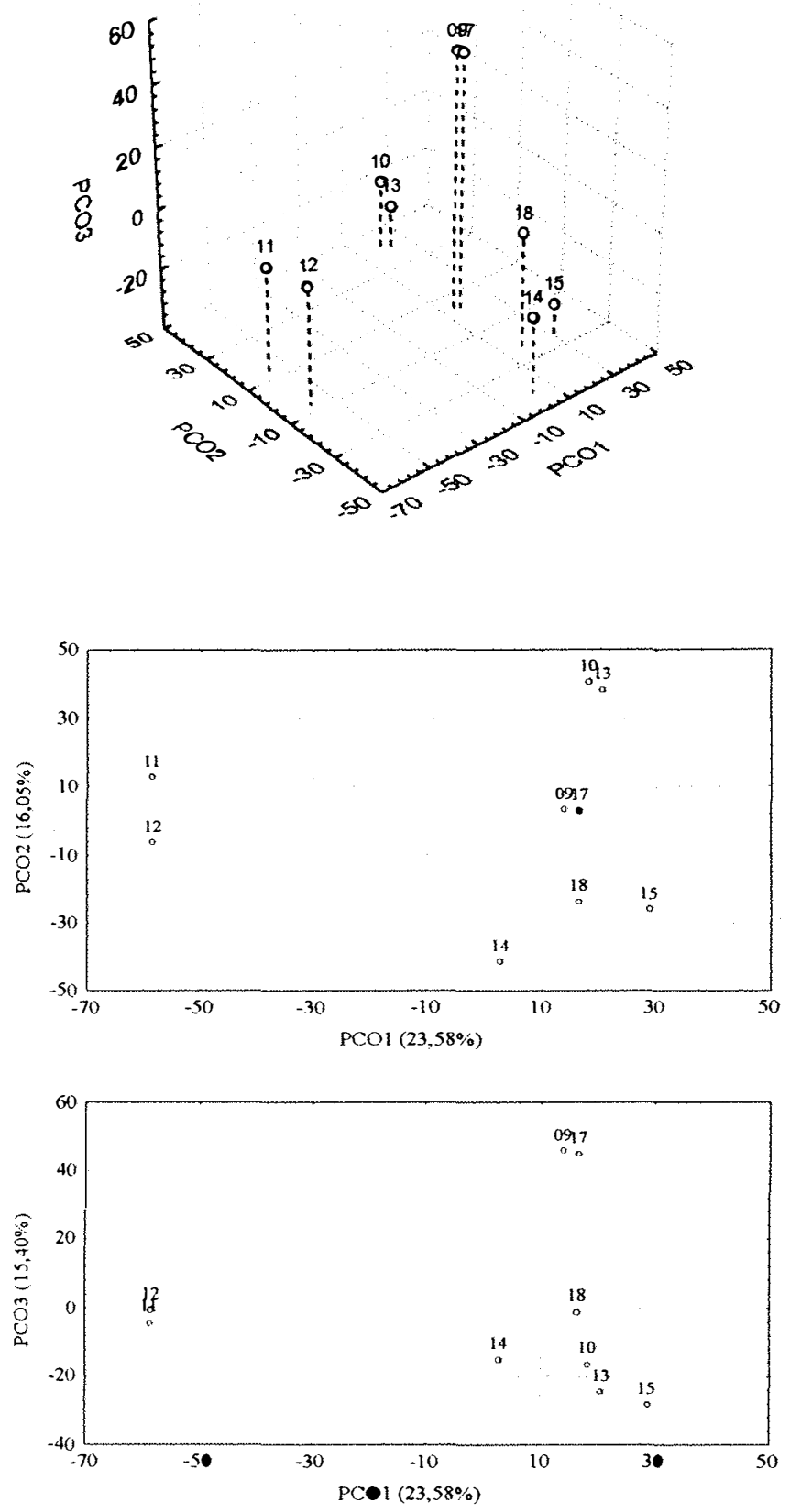

Figura 16. Associação das linhagens de milho da população BR-106 reveladas por análise de coordenadas principais (PCO) a partir das estimativas das capacidades específicas de combinação para o caráter altura da espiga. 


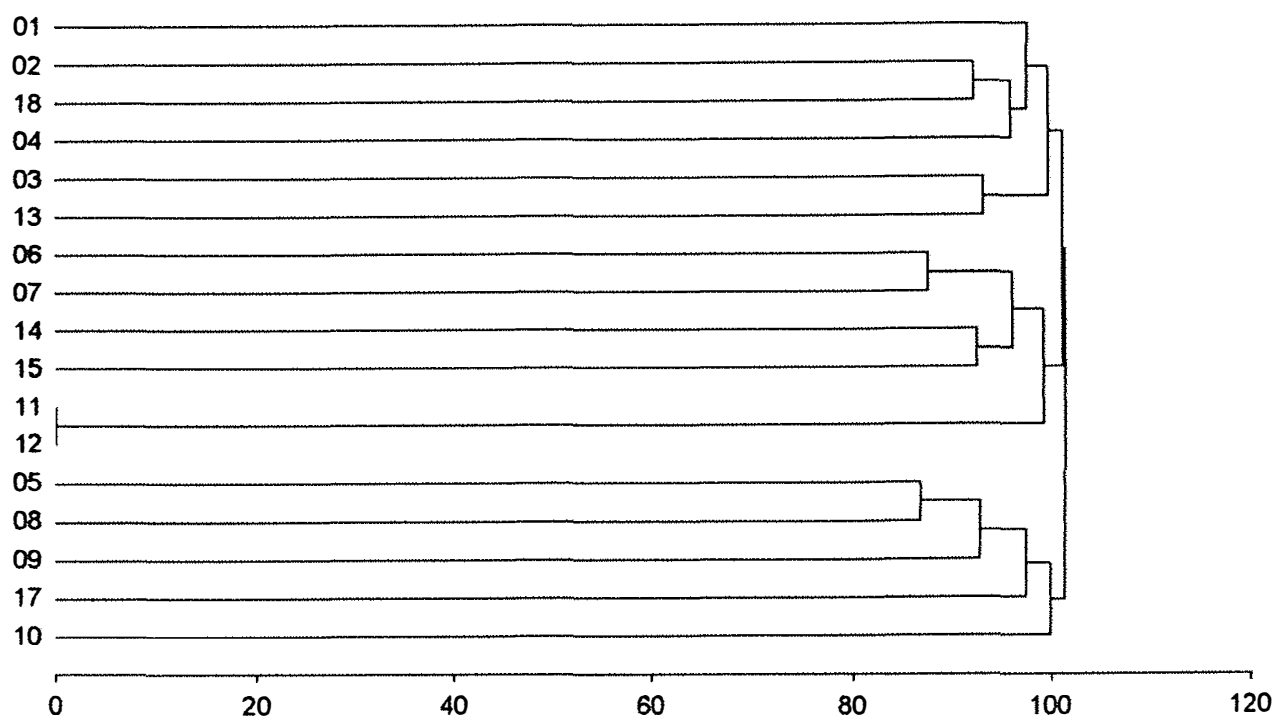

Figura 17. Dendrograma das linhagens de milho das populações BR-105 e BR-106 agrupadas segundo o método de UPGMA, para o caráter altura da espiga.

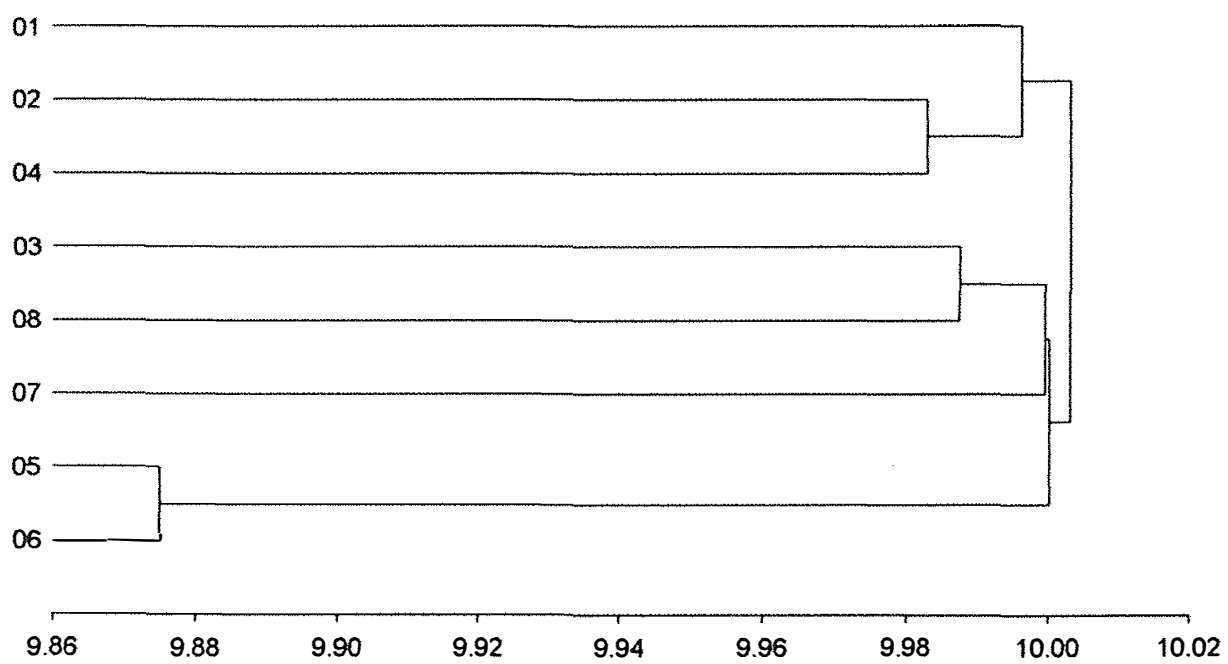

Figura 18. Dendrograma das linhagens de milho da população BR-105 agrupadas segundo o método de UPGMA, para o caráter posição relativa da espiga. 

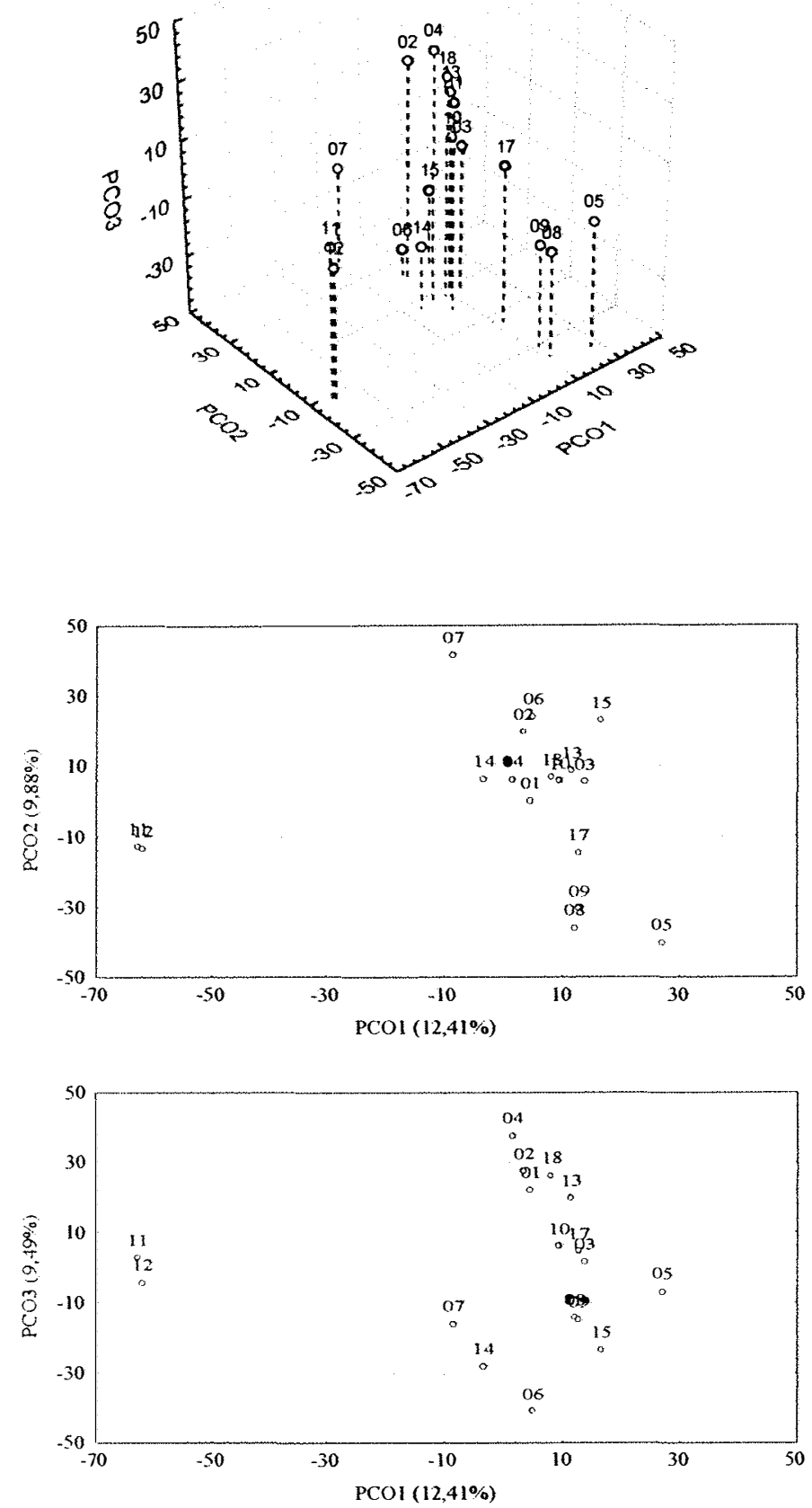

Figura 19. Associação das linhagens de milho das populações BR-105 e BR-106 reveladas por análise de coordenadas principais (PCO) a partir das estimativas das capacidades específicas de combinação para o caráter altura da espiga. 

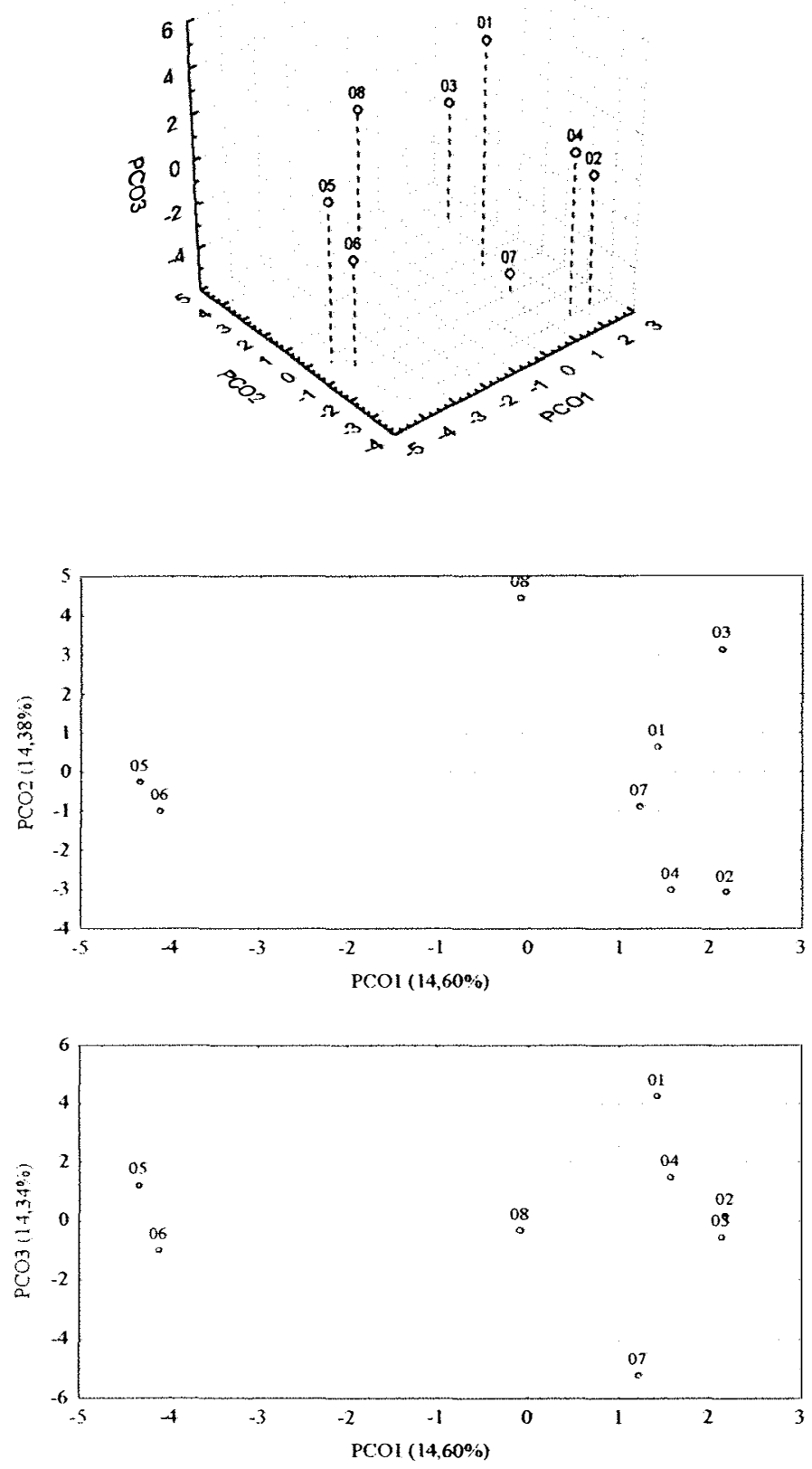

Figura 20. Associação das linhagens de milho da população BR-105 reveladas por análise de coordenadas principais (PCO) a partir das estimativas das capacidades específicas de combinação para o caráter posição relativa da espiga. 


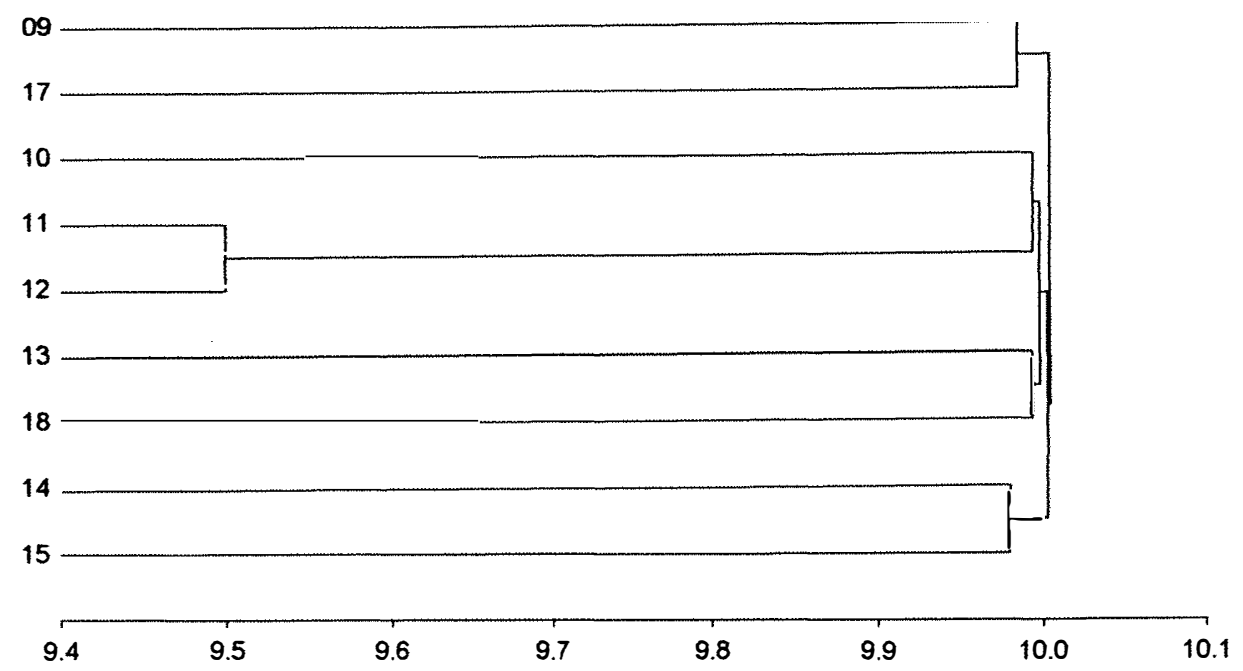

Figura 21. Dendrograma das linhagens de milho da população BR-106 agrupadas segundo o método de UPGMA, para o caráter posição relativa da espiga.

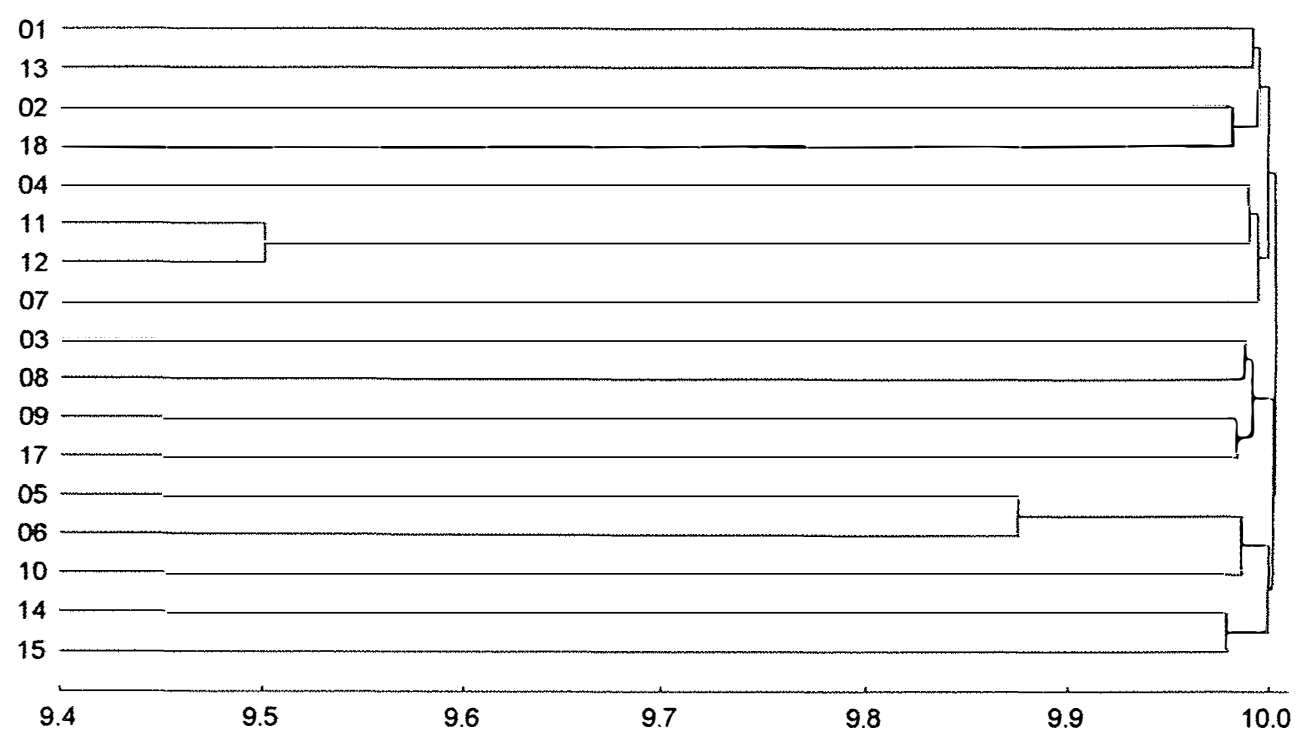

Figura 22. Dendrograma das linhagens de milho das populações BR-105 e BR-106 agrupadas segundo o método de UPGMA, para o caráter posição relativa da espiga. 

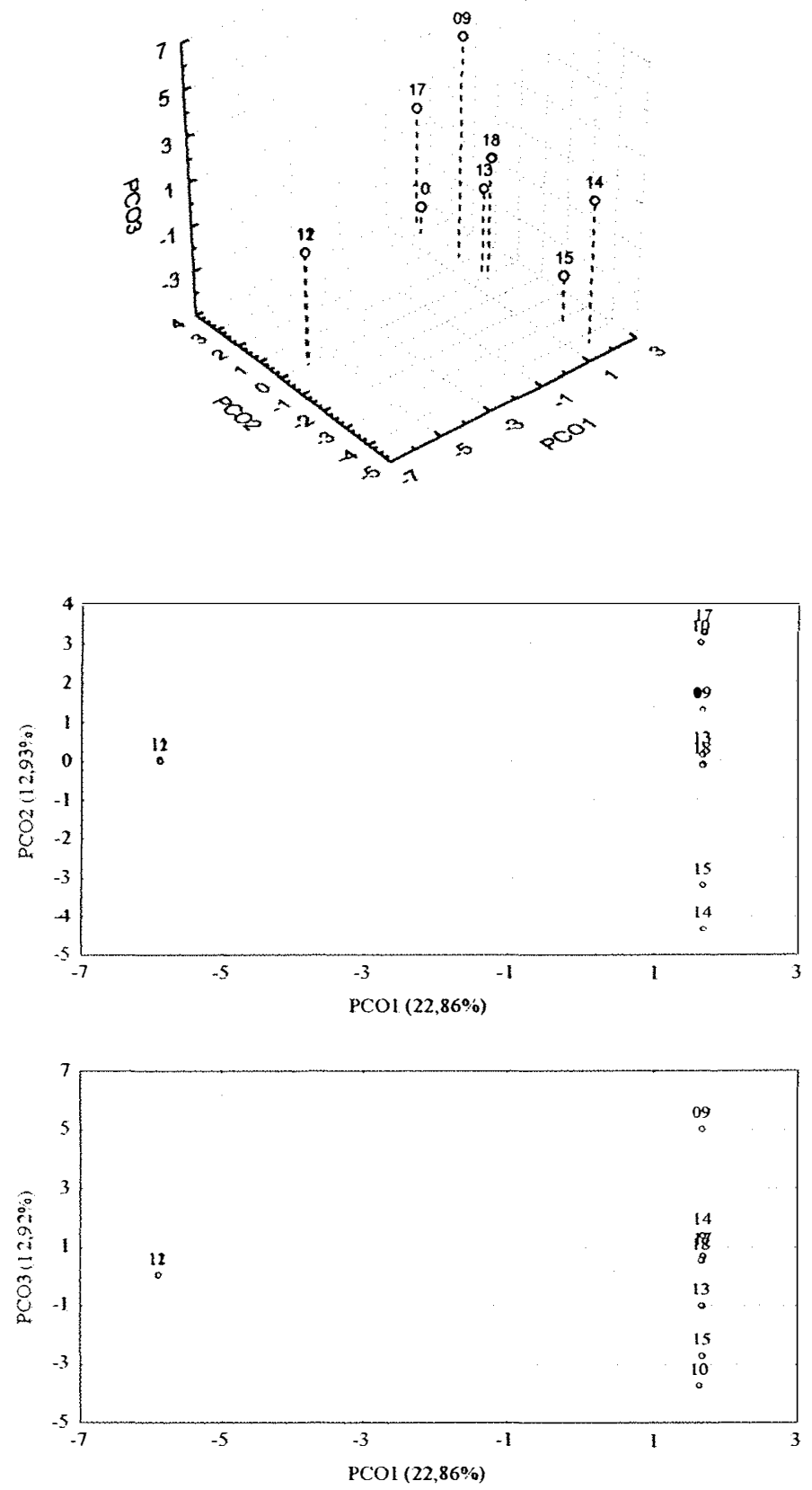

Figura 23. Associação das linhagens de milho da população BR-106 reveladas por análise de coordenadas principais (PCO) a partir das estimativas das capacidades específicas de combinação para o caráter posição relativa da espiga. 

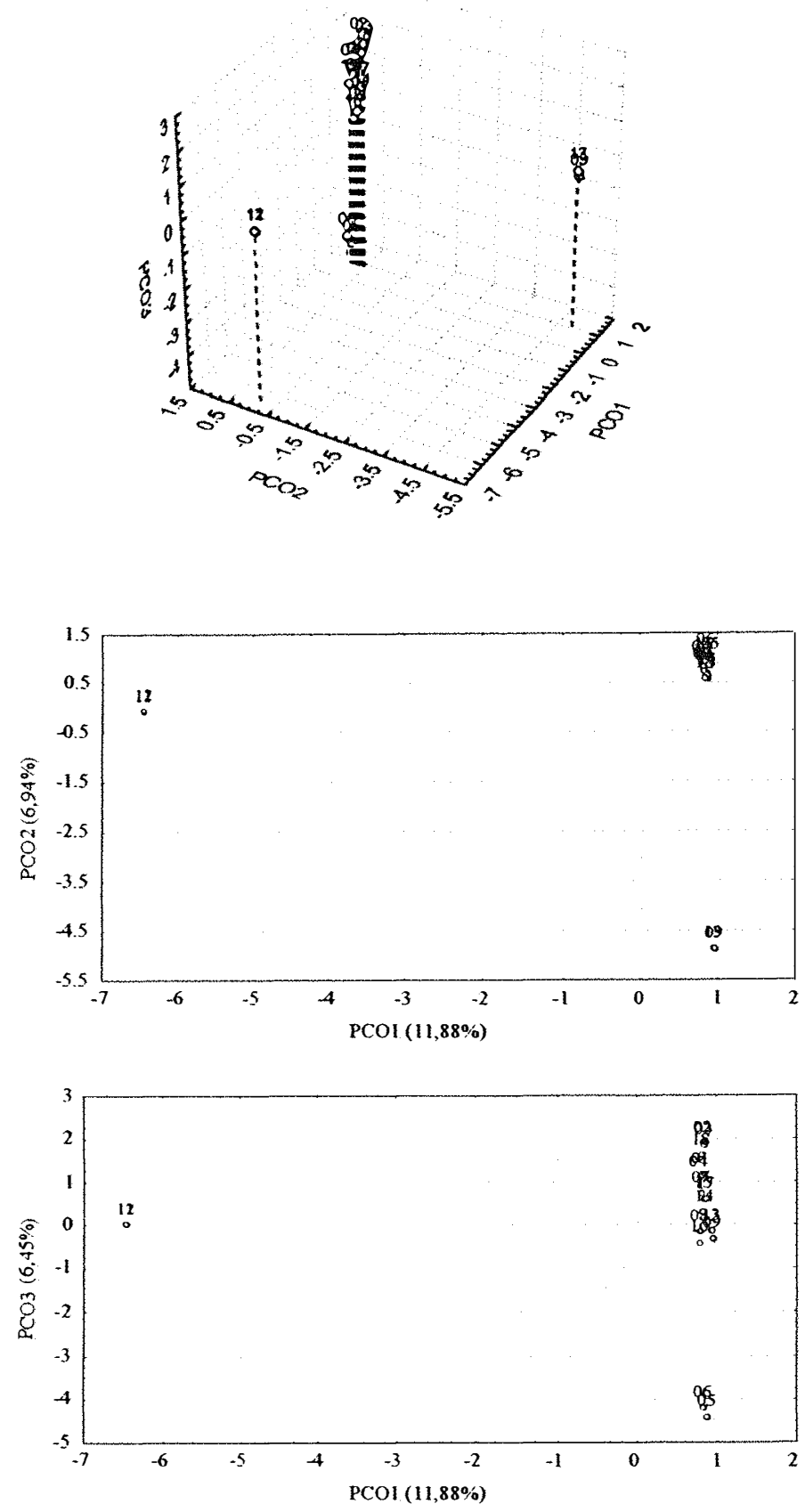

Figura 24. Associação das linhagens de milho das populações BR-105 e BR-106 reveladas por análise de coordenadas principais (PCO) a partir das estimativas das capacidades específicas de combinação para o caráter posição relativa da espiga. 


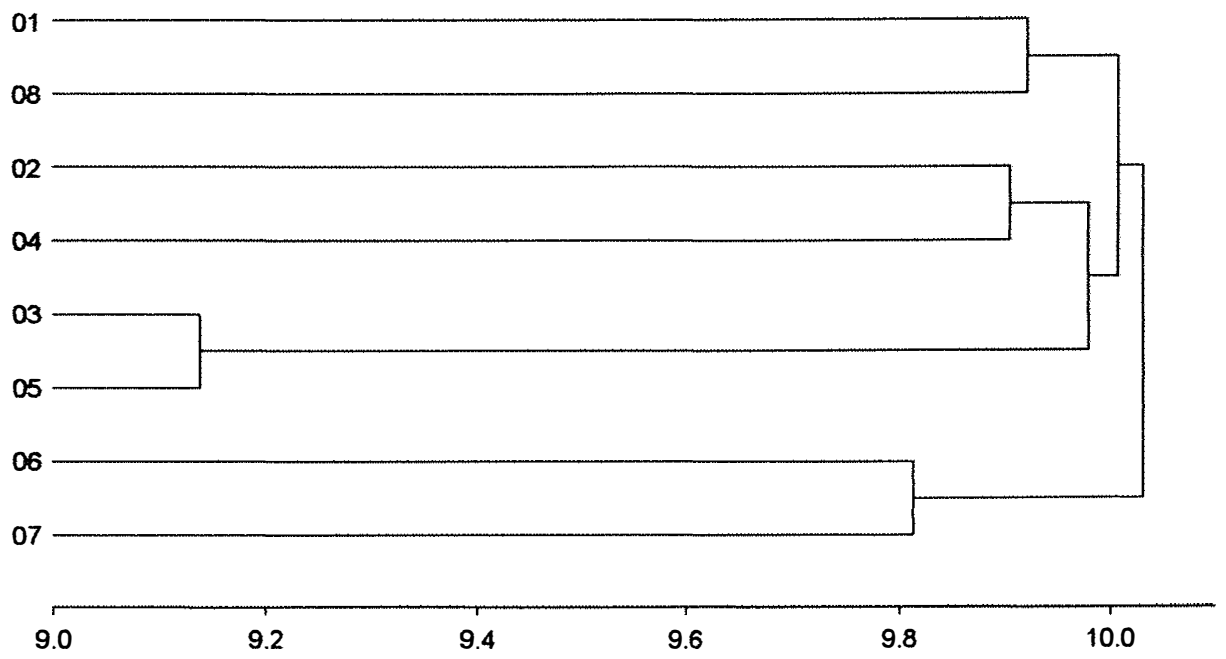

Figura 25. Dendrograma das linhagens de milho da população BR-105 agrupadas segundo o método de UPGMA, para o caráter prolificidade.

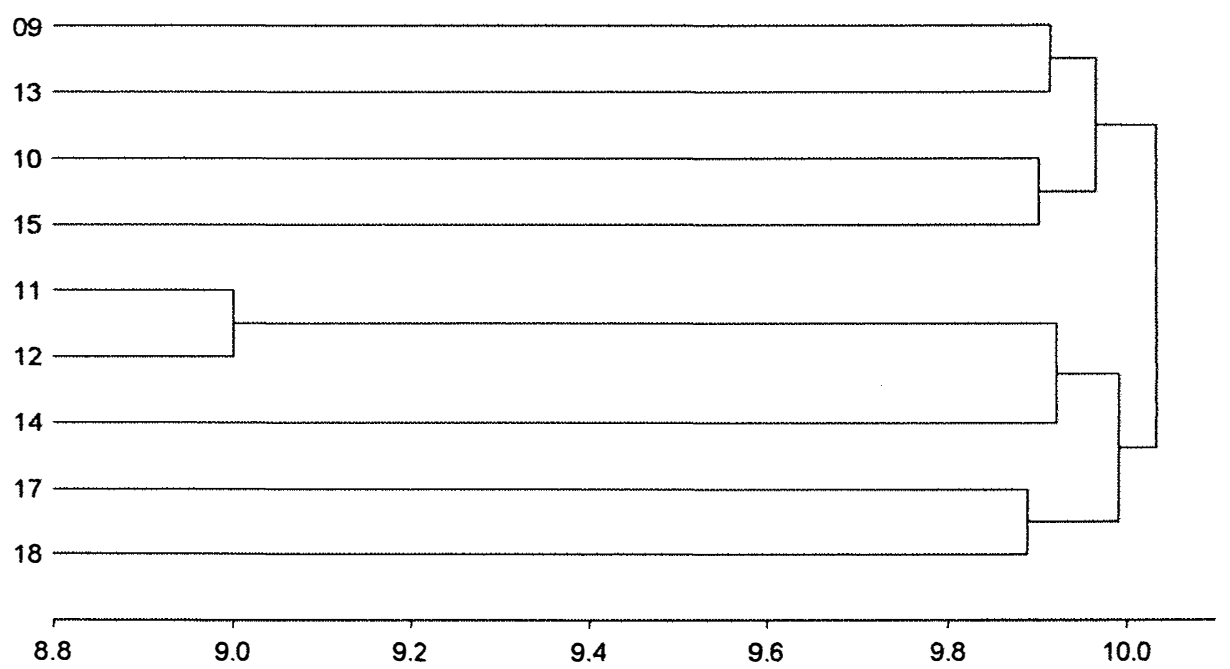

Figura 26. Dendrograma das linhagens de milho da população BR-106 agrupadas segundo o método de UPGMA, para o caráter prolificidade. 

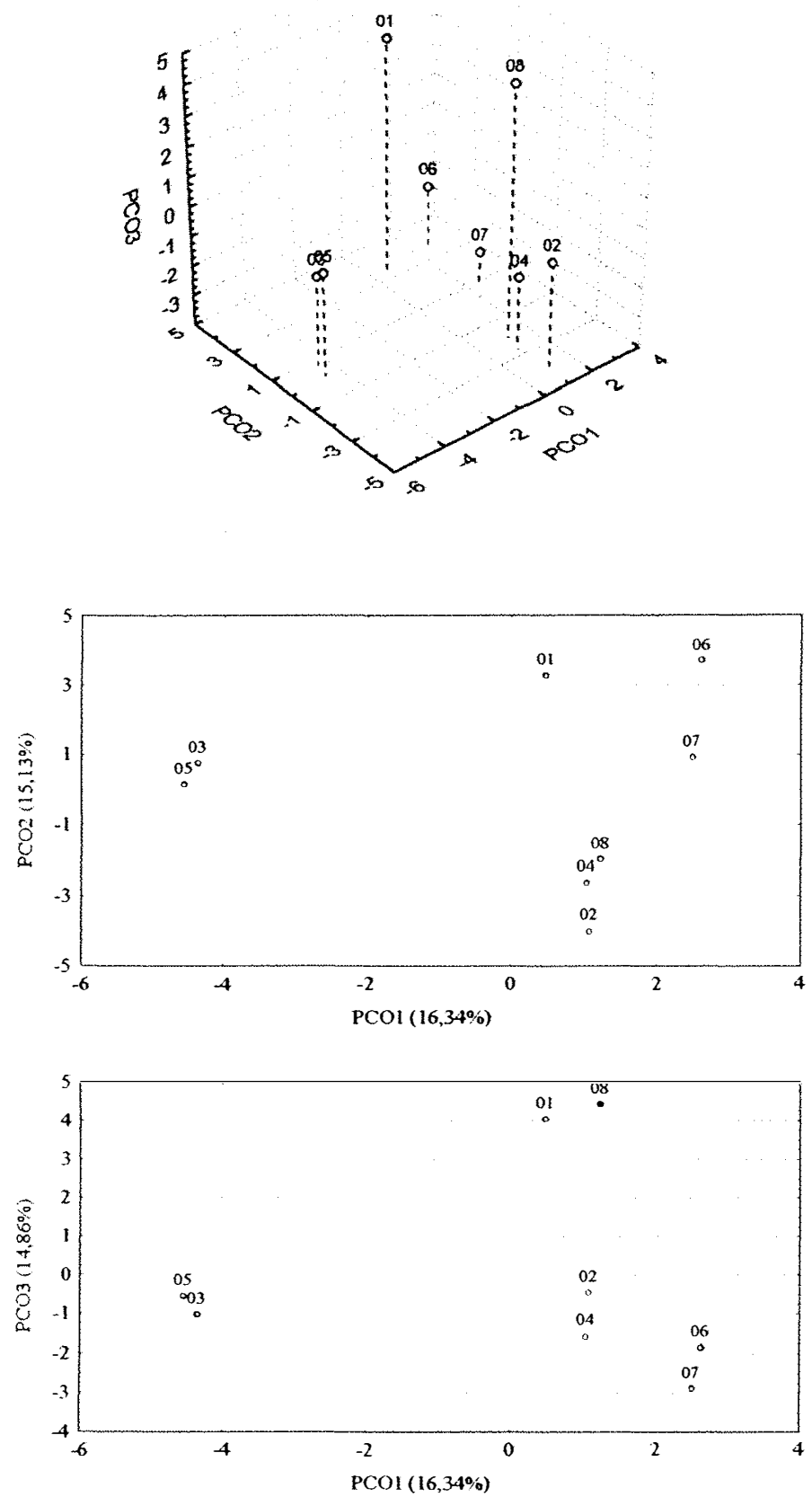

Figura 27. Associação das linhagens de milho da população BR-105 reveladas por análise de coordenadas principais (PCO) a partir das estimativas das capacidades específicas de combinação para o caráter prolificidade. 

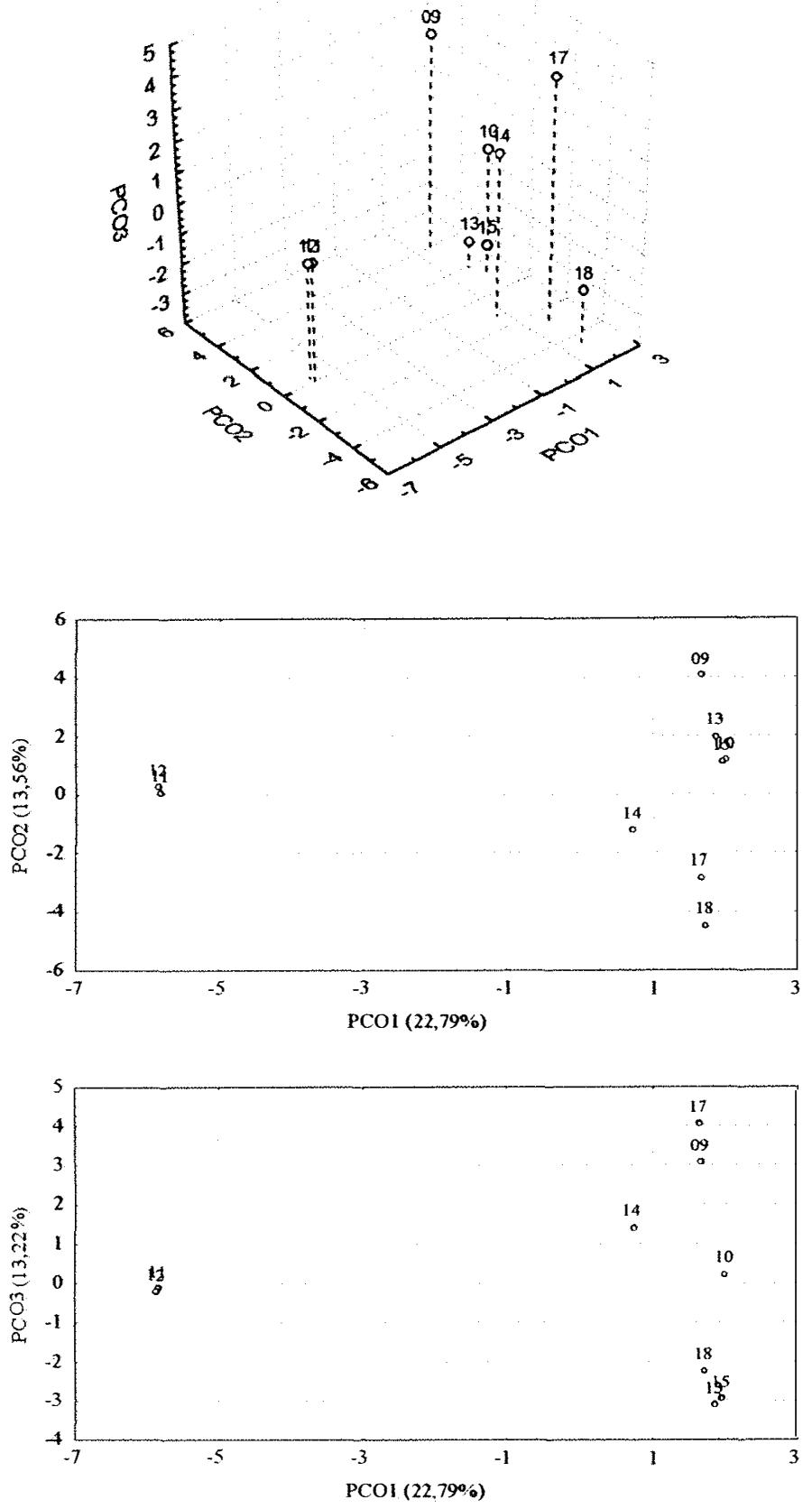

Figura 28. Associação das linhagens de milho da população BR-106 reveladas por análise de coordenadas principais (PCO) a partir das estimativas das capacidades específicas de combinação para o caráter prolificidade. 


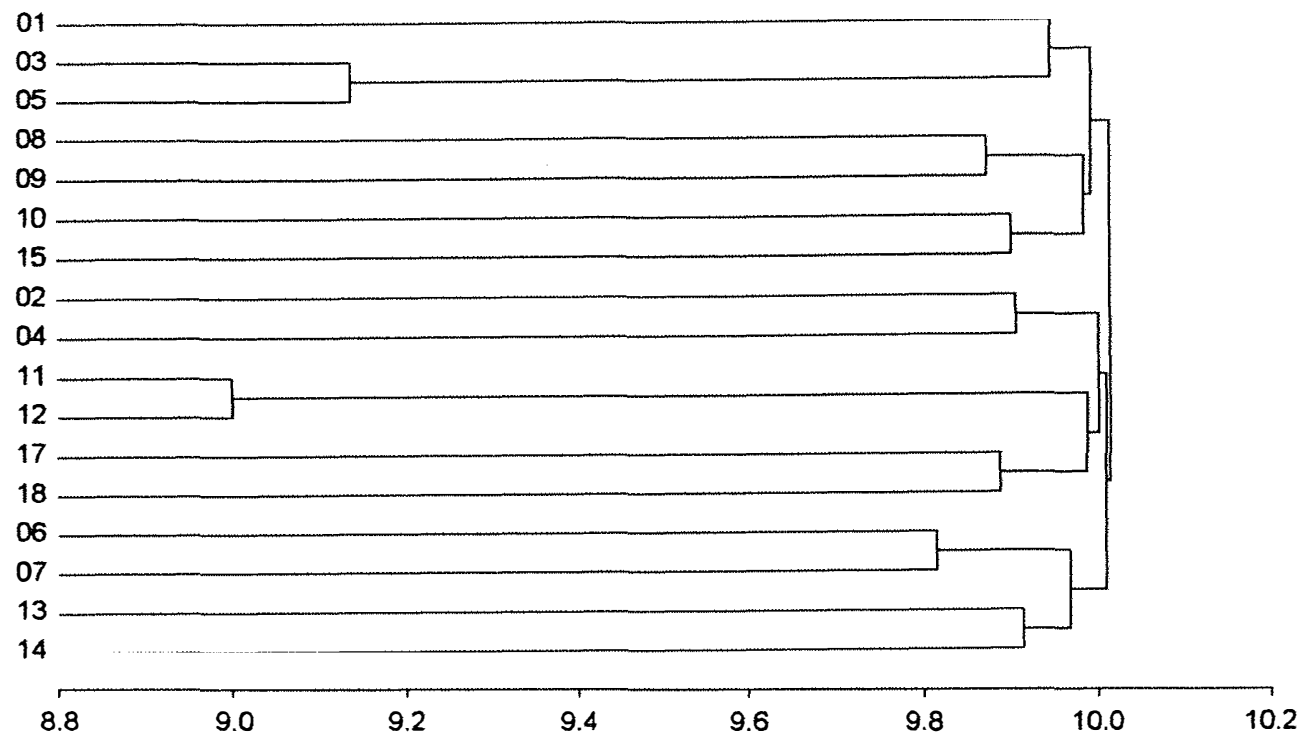

Figura 29. Dendrograma das linhagens de milho das populações BR-105 e BR-106 agrupadas segundo o método de UPGMA, para o caráter prolificidade.

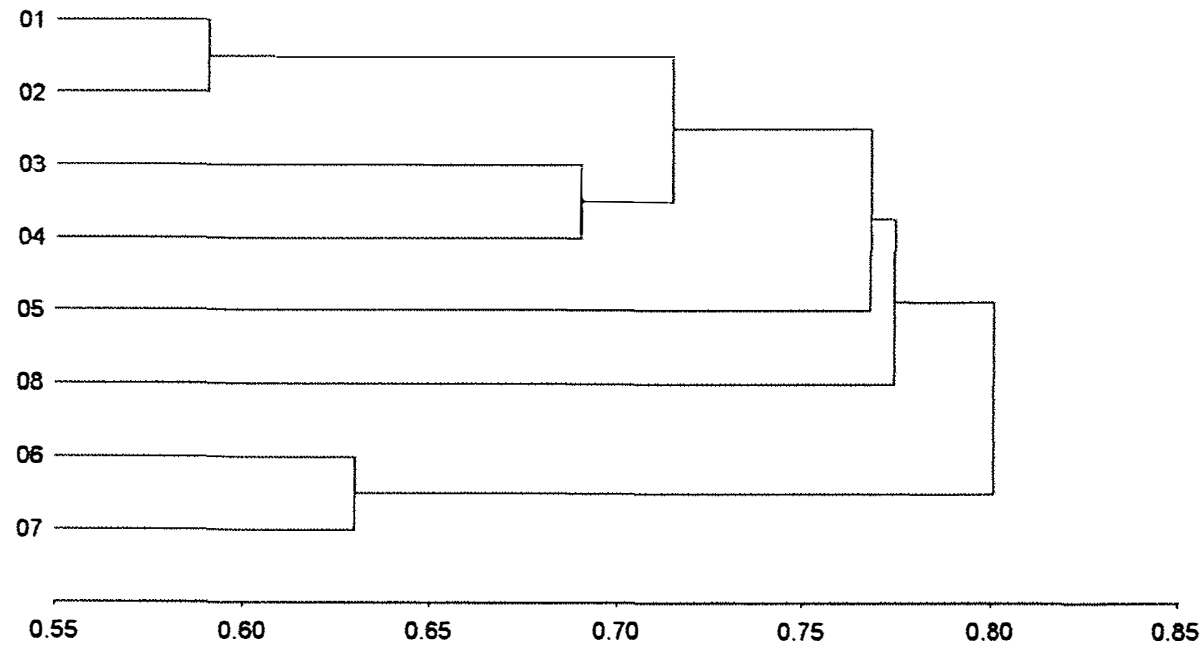

Figura 30. Dendrograma das linhagens de milho da população BR-105 agrupadas segundo o método de UPGMA, obtidas a partir de 1429 bandas polimórficas com RFLP. 

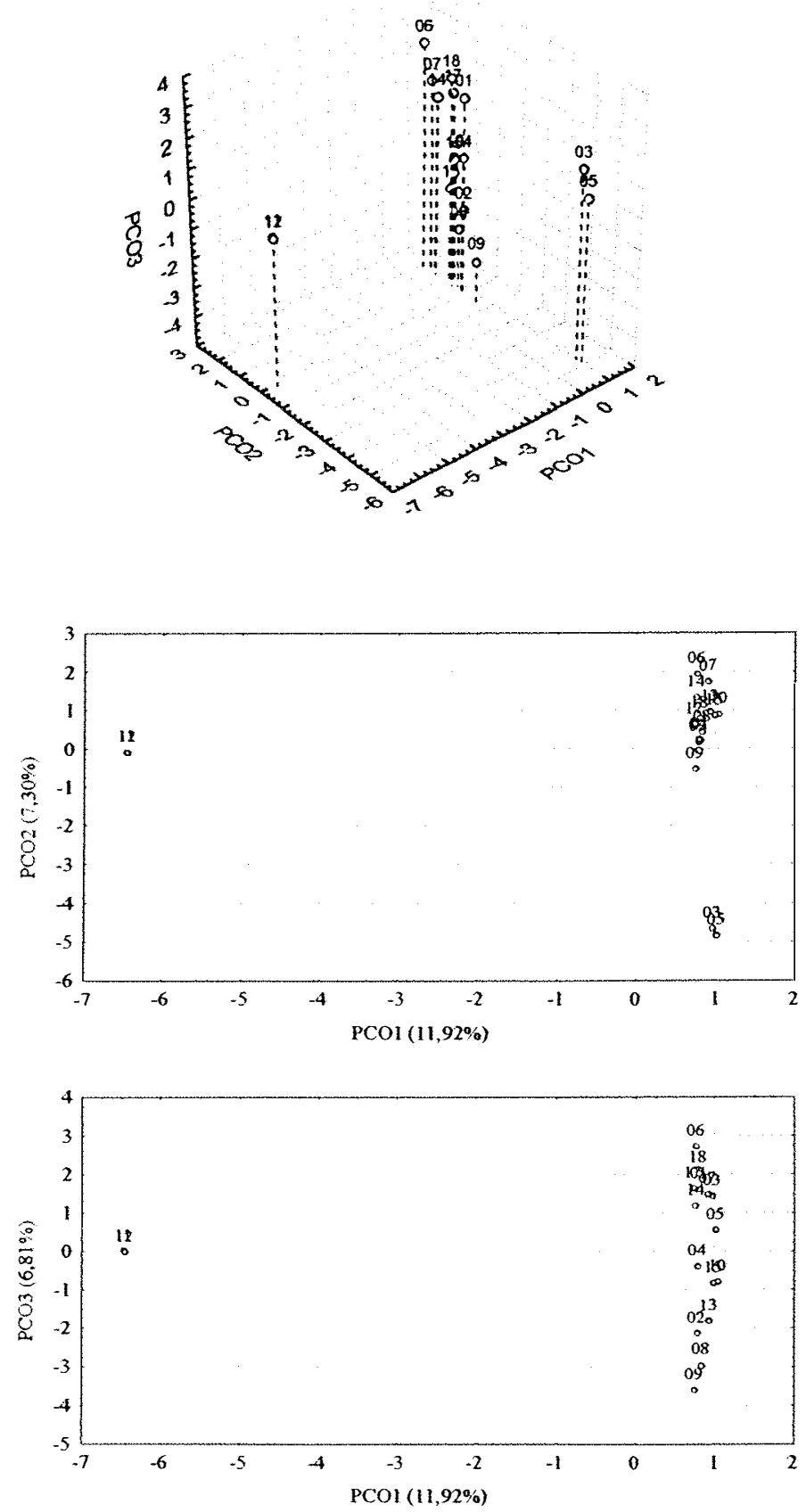

Figura 31. Associação das linhagens de milho das populações BR-105 e BR-106 reveladas por análise de coordenadas principais (PCO) a partir das estimativas das capacidades específicas de combinação para o caráter prolificidade. 

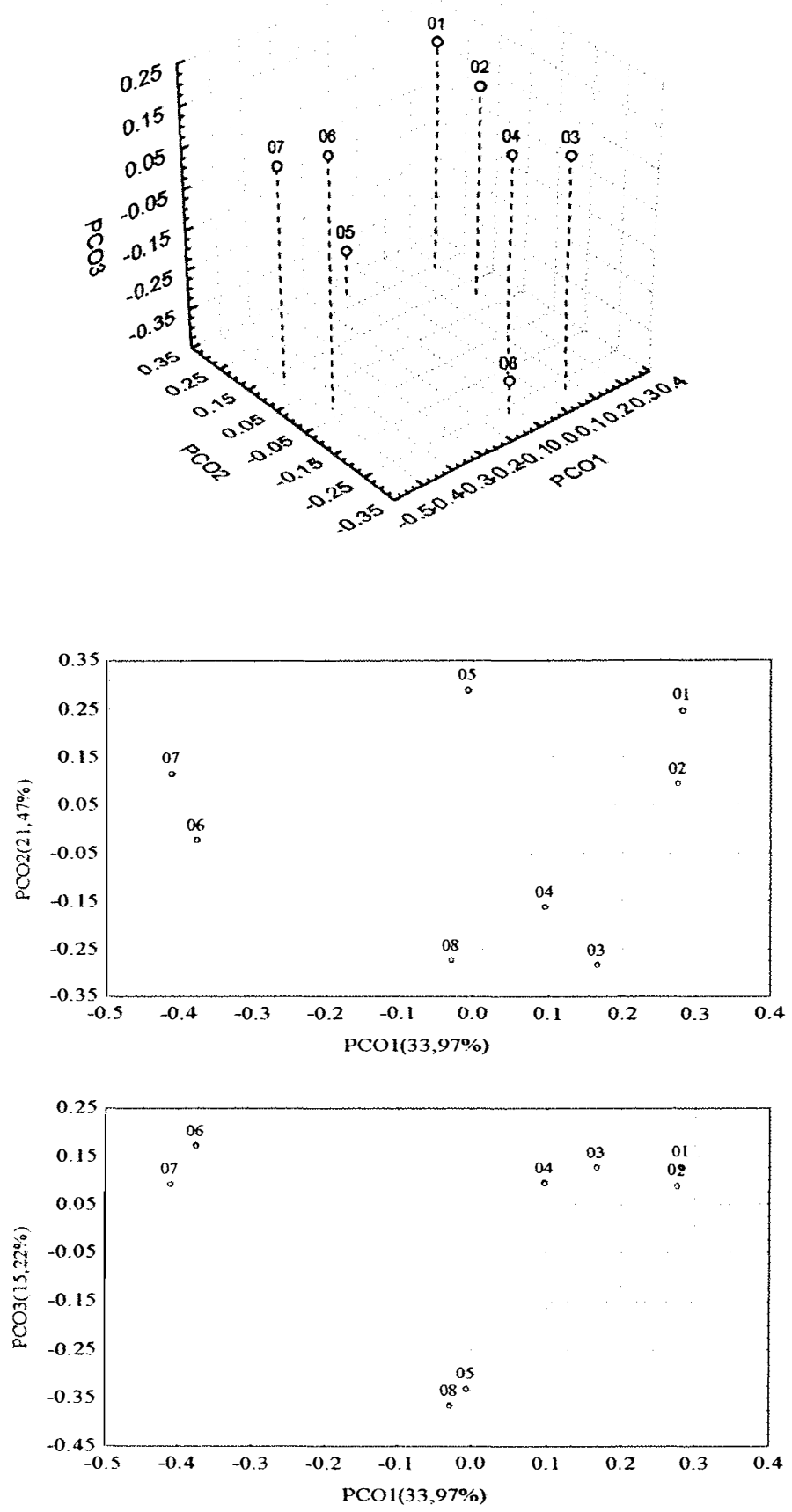

Figura 32. Associação das linhagens de milho da população BR-105 reveladas por análise de coordenadas principais (PCO) a partir das estimativas das distâncias genéticas obtidas pelo coeficiente de Jaccard a partir de 1429 bandas polimórficas com RFLP. 


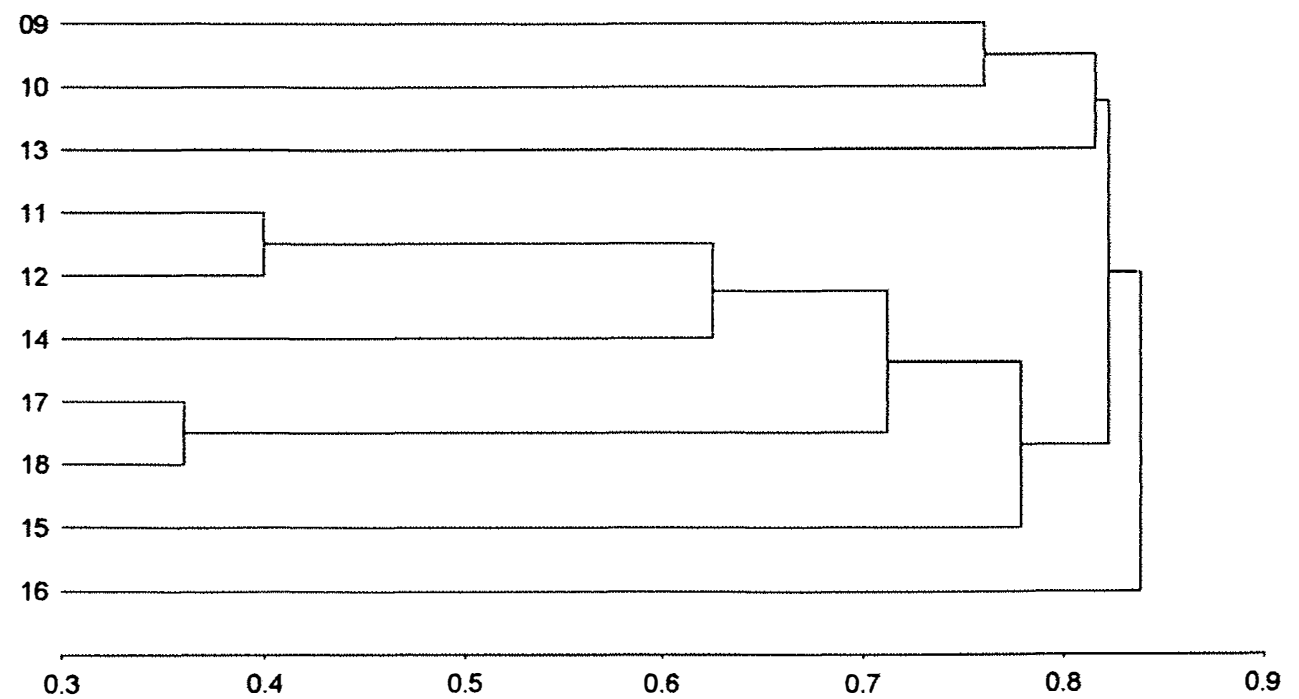

Figura 33. Dendrograma das linhagens de milho da população BR-106 agrupadas segundo o método de UPGMA, obtidas a partir de 1429 bandas polimórficas com RFLP.

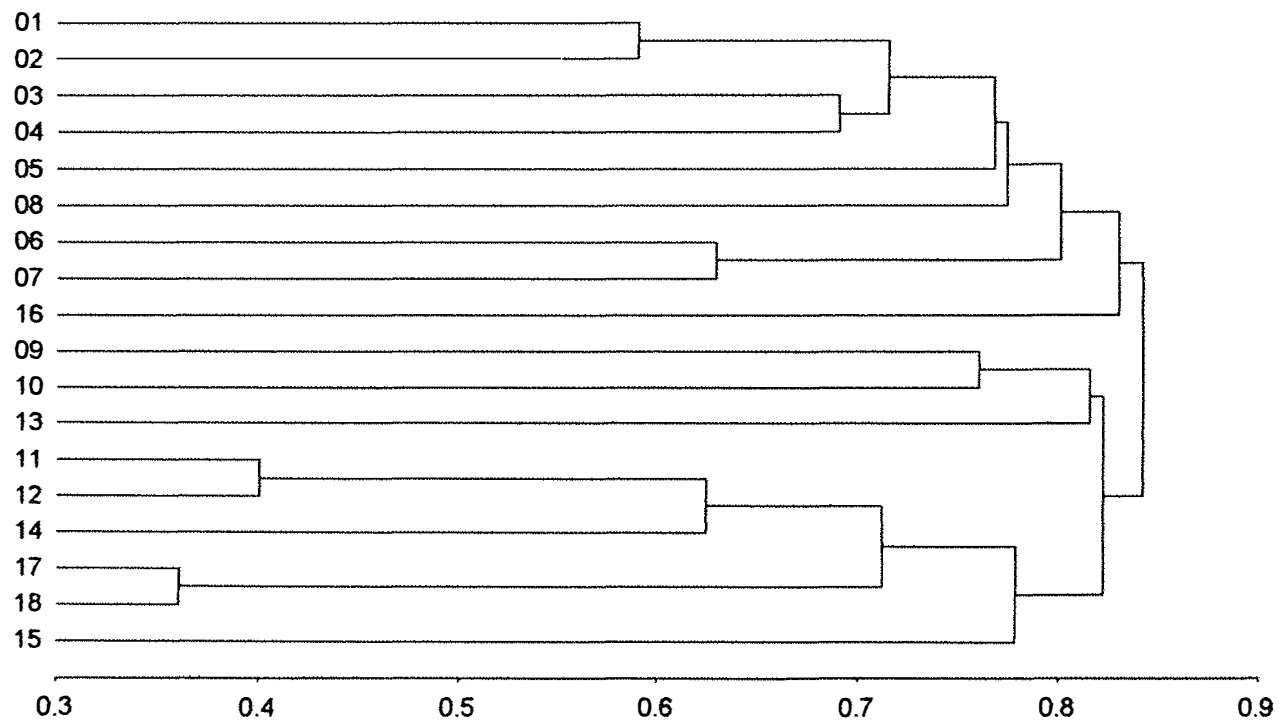

Figura 34. Dendrograma das linhagens de milho das populações BR-105 e BR-106 agrupadas segundo o método de UPGMA, obtidas a partir de 1429 bandas polimórficas com RFLP. 

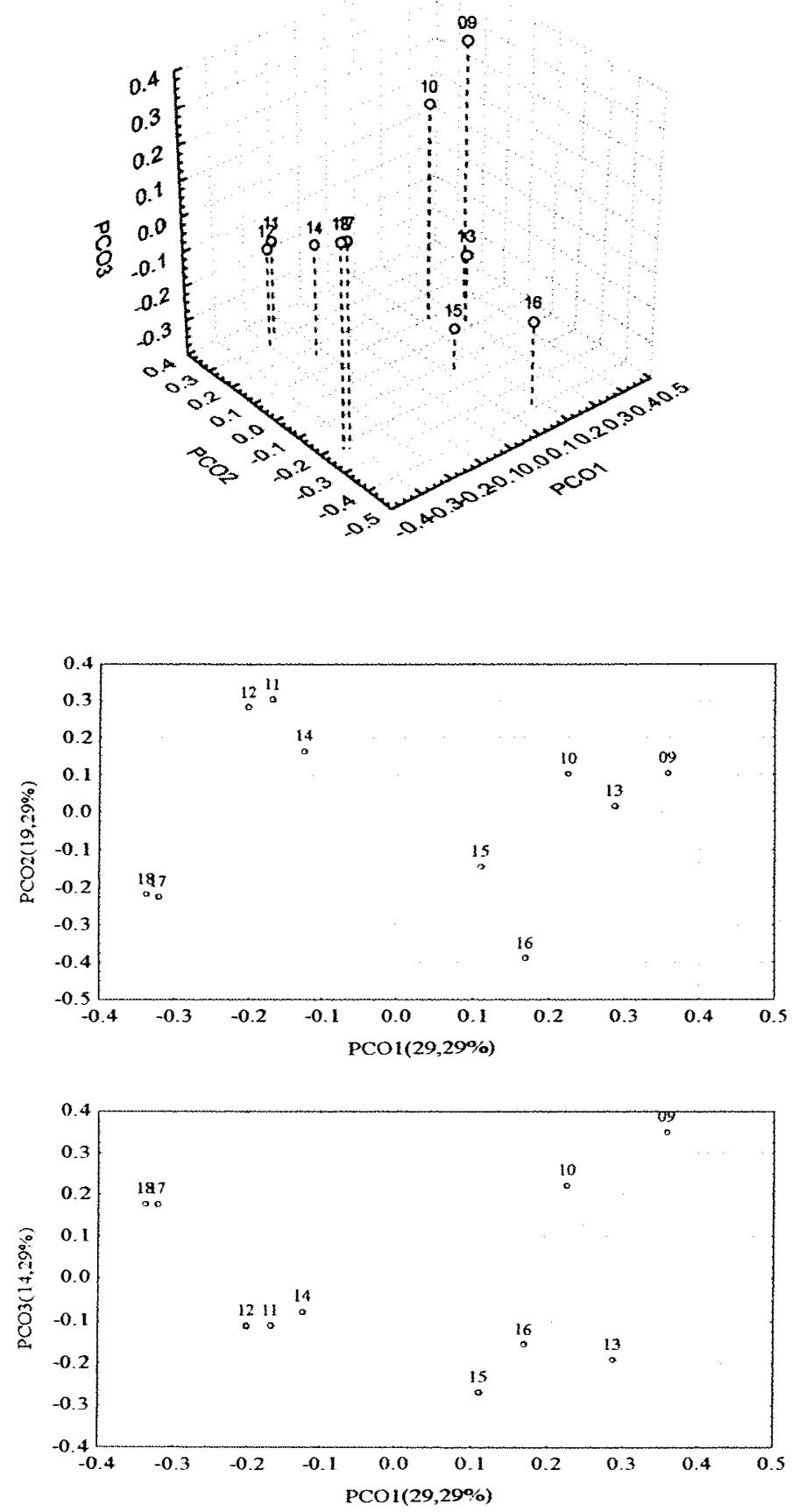

Figura 35. Associação das linhagens de milho da população BR-106 reveladas por análise de coordenadas principais (PCO) a partir das estimativas das distâncias genéticas obtidas pelo coeficiente de Jaccard a partir de 1429 bandas polimórficas com RFLP. 

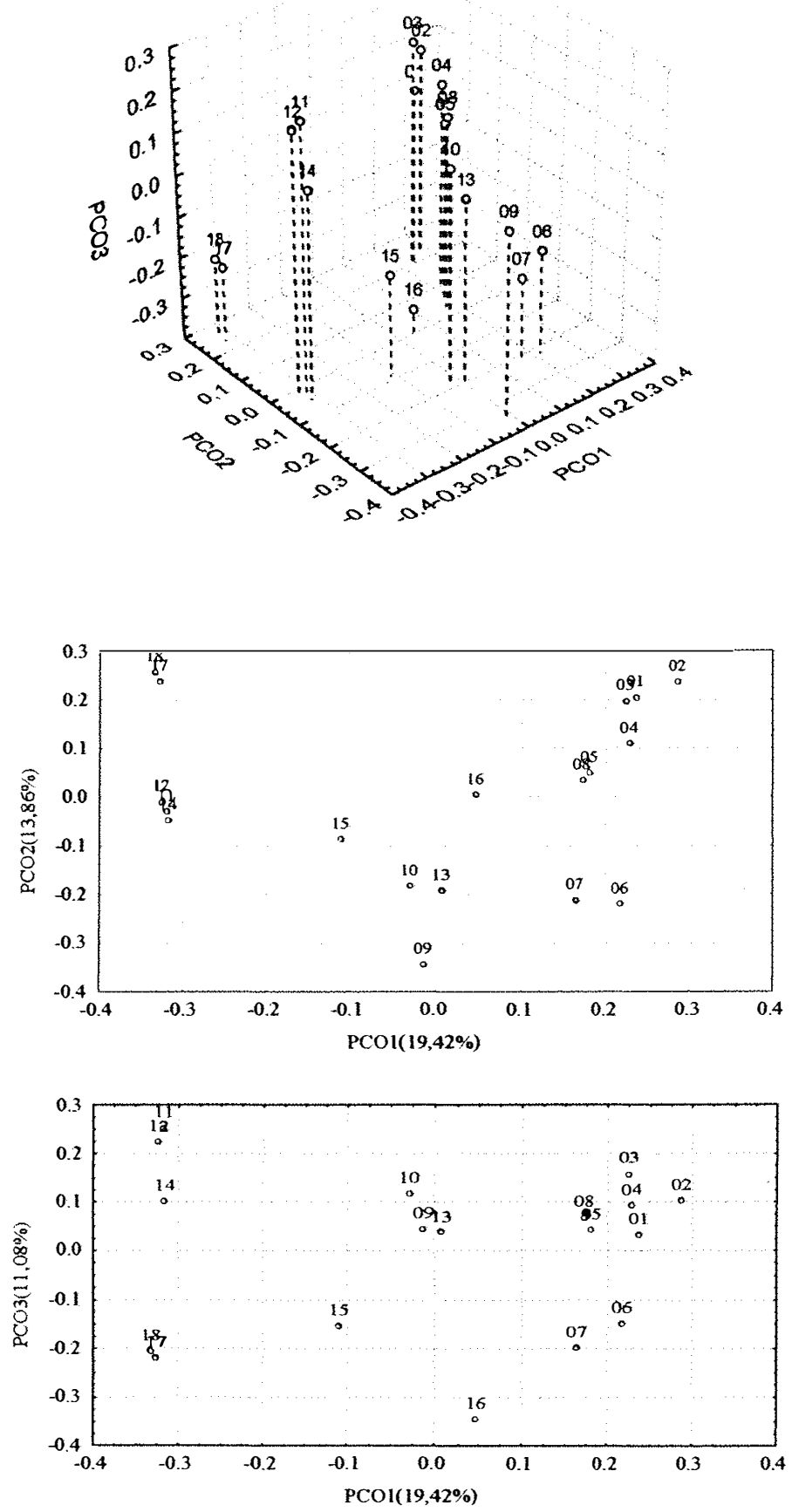

Figura 36. Associação das linhagens de milho das populações BR-105 e BR-106 reveladas por análise de coordenadas principais ( $\mathrm{PCO}$ ) a partir das estimativas das distâncias genéticas obtidas pelo coeficiente de Jaccard a partir de 1429 bandas polimórficas com RFLP. 


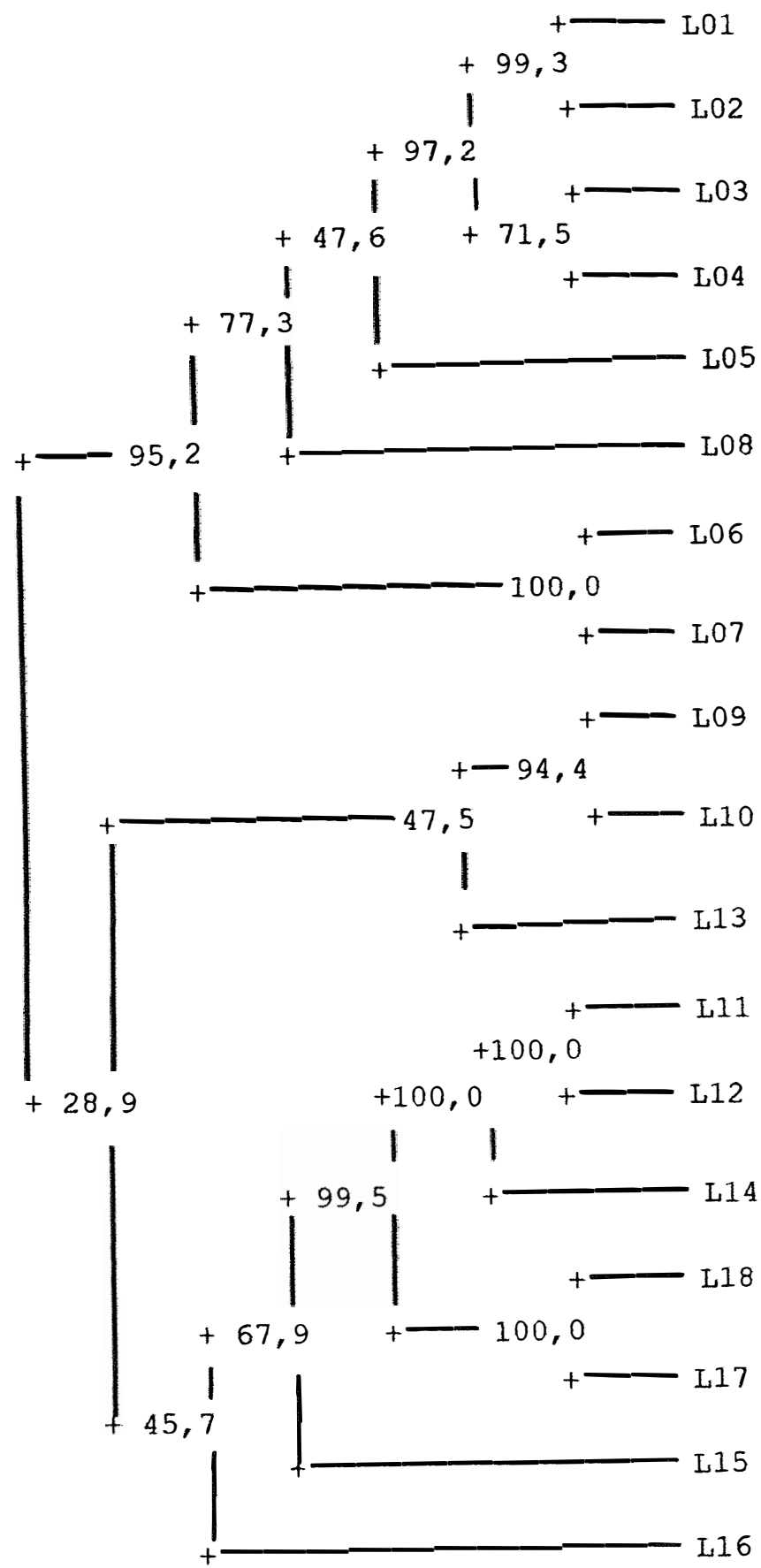

Figura 37. Dendograma das linhagens de milho das populações BR-105 e BR-106 agrupadas segundo a análise de Bootstrap (Felsenstein, 1985), obtidas a partir de 1.429 bandas polimórficas com RFLP. 